Göttinger Bibliotheksschriften 37 



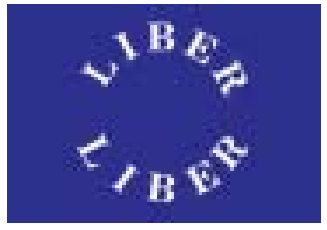

Ligue des Bibliothèques Européennes de Recherche Architecture Group

\section{Furtherance \\ of academic excellence}

Documentation of new library buildings in Cambridge

Compiled by Alison Wilson

Edited by Elmar Mittler

Göttingen

2006 


\title{
LIBER Architecture Group
}

\author{
Alessandro Bertoni \\ Marie-Françoise Bisbrouck \\ Graham Bulpitt \\ Veronica Gusso \\ Ewa Kobierska-Maciuszko \\ Steen Bille Larsen \\ Elmar Mittler \\ Ulrich Niederer \\ Tanja Notten
}

Göttinger Bibliotheksschriften 37

(C) Niedersächsische Staats- und Universitätsbibliothek Göttingen 2006

ISBN 10 : 3-930457-81-4

ISBN 13 : 978-3-930457-81-6

ISSN 0943-951X 


\section{Table of contents}

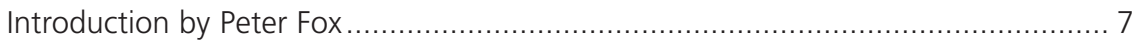

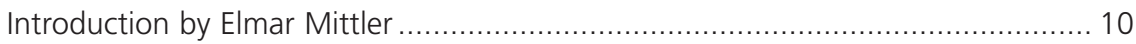

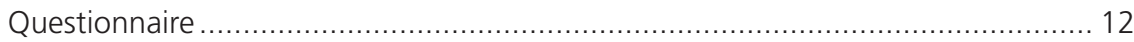

Cambridge University Library - Legal Deposit and University Library ................... 31

Cambridge University Library - Betty and Gordon Moore Library for the Physical Sciences, Mathematics and Technology .............................. 53

Cambridge University Library - Squire Law Library at the Faculty of Law ..............63 63

Department of Chemistry Library ............................................................. 75

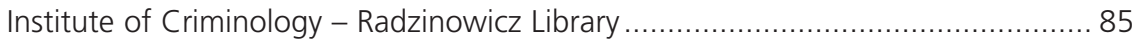

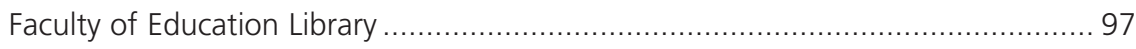

Scott Polar Research Institute Library ......................................................... 105

Clare College - Forbes Mellon Library …................................................ 111

Girton College Library and Archive ......................................................... 123

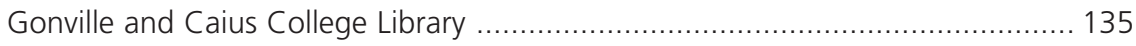

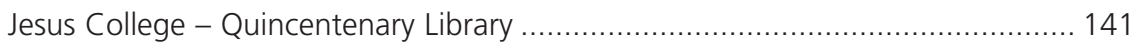

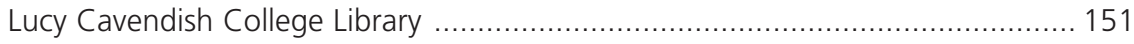

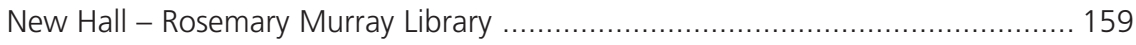

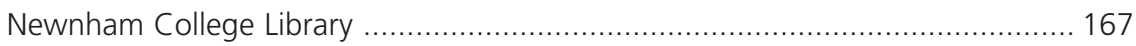

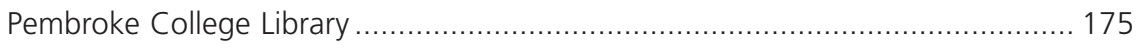

Peterhouse - Ward Library Gunn Gallery ................................................... 183

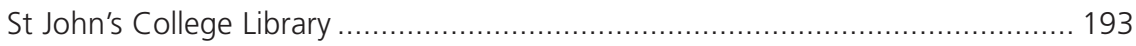

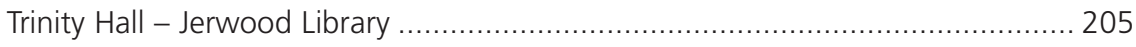

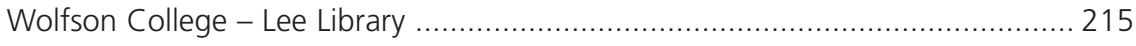





\section{INTRODUCTION}

This book has its origins in a paper entitled 'Recent developments in Cambridge college libraries', presented by Alison Wilson, Librarian of New Hall, Cambridge, at the LIBER Architecture Group Conference, 'Changing Needs, Changing Libraries', which took place in Utrecht in March 2006. ${ }^{1}$ At the conference, Professor Elmar Mittler, Chairman of the LIBER Architecture Group, was so struck by the scale and quality of library building that had been undertaken in Cambridge over the last couple of decades that he decided to commission this volume in the series of Göttinger Bibliotheksschriften to document that development.

The University of Cambridge's current Libraries Directory lists 113 libraries, organised in a tripartite structure, namely the University Library, the faculty and departmental libraries, and the college libraries. ${ }^{2}$

Cambridge University Library is the principal research library of the University, and one of the great libraries of the world. Organisationally it consists of the main University Library building (with internationally important collections and around 8 million volumes housed on 130 kilometres of shelving), the Central Science Library (for chemical and biological sciences), the Betty and Gordon Moore Library (for physical sciences, mathematics and technology), the Squire Law Library, and the Medical Library.

All the faculties and departments have their own libraries, which range from small collections of journals to major libraries in their own right, with research materials and special collections of manuscripts and archives. There are also specialised research institutes with libraries.

Finally, each of the 31 colleges has a library (in some cases more than one). Several of these are world famous collections housed in buildings of architectural importance: the library of Trinity College, designed by Sir Christopher Wren and holding over 1000 medieval manuscripts, books from Sir Isaac Newton's own library, and Wittgenstein's

1 For the proceedings of the conference, including Alison Wilson's paper, see LIBER Quarterly, 16/2 (2006), http://webdoc.gwdg.de/edoc/aw/liber/

2 For details and a full list see the Cambridge University Libraries Directory, http:// www.lib.cam.ac.uk/University/Libraries/ 
notebooks; Magdalene College, with the library of Samuel Pepys; and the Parker Library at Corpus Christi College, with the finest collection of Anglo-Saxon manuscripts in the world, as well as the sixth-century Canterbury Gospels, the oldest illustrated Latin Gospel book now in existence, which is used for the enthronement of each new Archbishop of Canterbury.

Though Cambridge is one of the oldest universities in the world, currently planning for its $800^{\text {th }}$ anniversary in 2009, it is an institution that very much looks to the future, as well as drawing inspiration from the achievements of the past. This applies to its libraries as much as anywhere else in the University. Library building developments have been driven by a combination of the need to provide working space for the growing numbers of students and researchers, to accommodate the changing role of the library as electronic information resources become ever more important, and the need to provide more space and better storage conditions for the growing collections and for the treasures housed in the libraries.

This book covers only a selection of the new library buildings constructed in Cambridge in the last twenty years but it gives a flavour of the different ways that institutions have approached the need for new library space, given the varying constraints that they faced - these might have been financial, spatial (fitting a new library or an extension into an already crowded space) or architectural (inserting a new construction among existing buildings of great architectural importance). The book contains chapters on the main University Library and two of its 'dependent libraries' (the Betty and Gordon Moore and the Squire), the libraries of the Department of Chemistry, the Institute of Criminology and the Faculty of Education, as well as libraries in ten of the colleges. It was not possible to include other college libraries, such as those at Downing, Queens' or Darwin, or some faculty libraries such as Divinity and English.

In some cases, such as the Betty and Gordon Moore Library, the Quincentenary Library at Jesus College and the Lee Library at Wolfson College, the library is a completely new construction. In others the new library space is an extension to an existing building, with a totally modern character but designed to blend with the original building, such as at Trinity Hall and Pembroke College, or the University Library, where the 1930s style of the original architect, Sir Giles Gilbert Scott has been maintained but at the same time the latest in environmental controls, security and lighting have been incorporated. Some colleges, such as Corpus Christi and Peterhouse, have adapted existing buildings - in these two instances a bank and a storeroom. In all cases, the quality of the Cambridge architectural environment means that new libraries have to be built to high standards of design, construction and finish - and, sitting alongside 
buildings that may date back to the $16^{\text {th }}$ century, they are themselves expected to have a long life!

I am delighted that Elmar Mittler proposed this book, and its publication will mark almost his last act before retirement at the end of a highly distinguished career, which included the signing of a co-operation agreement between the Staats- und Universitätsbibliothek Göttingen and Cambridge University Library. I should like to record my thanks to Alison Wilson, who assembled the data for the book, and to all the librarians and architects who contributed both to the book and, more importantly, to the planning and design of these libraries, that will remain among the glories of Cambridge for future generations of students, scholars and visitors.

Cambridge, September 2006

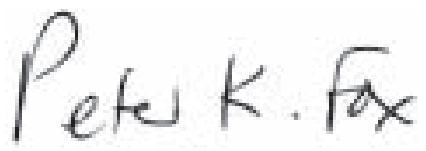

Peter K. Fox

University Librarian, University of Cambridge

General Secretary, LIBER 
Designing library buildings is in many ways a unique task:

Libraries

- have diverse functions and aims

- play a leading role as cultural institutions

- are communication centres for different groups of clients

- are fast developing as 'information institutions'.

They are often unique tasks for architects as well, since they usually have only a once in a lifetime's opportunity to build a library. This increases the prospect of new ideas being continually brought into the development of library buildings, but there is nevertheless a danger that inexperience may result in shortcomings. Excellent communication is therefore essential to make library architecture a successful experience for architects, librarians and users.

The LIBER Architecture Group, its seminars', pre-seminar tours and publications together form the marketplace for professional information, the exchange of new ideas and discussion of recent developments. The documentations ${ }^{2}$ from 2000 on offer an overview of new research library buildings at European level.

Furtherance of Academic Excellence, the record of new libraries in Cambridge, is the first volume to concentrate on single towns or universities. In this instance, some of the normal selection rules have been disregarded: for example, some libraries under 1,000 square metres and new buildings or extensions more than five years old have been included. This provides a fascinating opportunity to walk around the university

1 http://www.zhbluzern.ch/LIBER-LAG/lageps.htm

2 http://www.zhbluzern.ch/LIBER-LAG/lagepub.htm

The Open Library - Financial and Human Aspects. Documentation of the new library buildings in Europe, ed. by Ewa Kobierska-Maciuszko for the LIBER Architecture Group Seminar, Warsaw 12-14 April 2000, Warsaw: Warsaw University Library 2000.

The Effective Library - Vision, Planning Process, and Evaluation. Documentation of new library buildings in Europe, ed. by Elmar Mittler for the LIBER Architecture Group Seminar, Leipzig 19-22 March 2002, Göttingen: Niedersächsische Staats- und Universitätsbibliothek 2002.

The Renaissance of the Library - adaptable library buildings. Documentation of new library buildings in Europe, ed. by Elmar Mittler for the LIBER Architecture Group Seminar, Bozen/ Bolzano and Venice 15-19 March 2004, Göttingen: Niedersächsische Staats- und Universitätsbibliothek 2004.

Changing Needs - Changing Libraries. Documentation of new library buildings in Europe, ed. by Elmar Mittler for the LIBER Architecture Group Seminar, Utrecht and Gent, 20-25 March 2006, Göttingen: Niedersächsische Staats- und Universitätsbibliothek 2006. 
town of Cambridge visiting library buildings, from the extension of the University Library to the small but beautiful College Library. The full range of modern architecture is immediately visible, modernism and post-modernism, future-oriented new experiments as well as traditional extensions - a real park of library architecture.

I should like to express my thanks to Alison Wilson of Cambridge. Her very interesting paper at the LIBER Architecture Group seminar in Utrecht gave me the idea of broadening the view and making a full record of recent library architecture in Cambridge ${ }^{3}$. Alison Wilson kindly supported this idea, colleagues in Cambridge furnished the information, and Peter Fox, Director of the University Library, gave advice and help to complete the work. Thanks are due to all contributors to this issue, to Michael Kakuschke who undertook responsibility for the PDF-file, which is available both in print and online and last but not least to Claudia Krell und Baris Özyurt who assisted with formatting many pictures.

It is a special pleasure for me to dedicate this work to my colleagues in the LIBER Architecture Group with my best wishes for fruitful and successful activities in the future.

Goettingen, September 2006
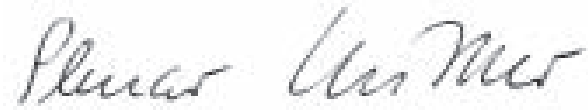

Dr. Dr. h. c. Elmar Mittler

Professor of Book and Library Sciences

Chairman of the LIBER Architecture Group

3 Wilson, Alison: Recent developments in Cambridge College Libraries, in: LIBER Quarterly (16) 2006.

http://webdoc.gwdg.de/edoc/aw/liber/lq-2-06/wilson.pdf 


\title{
LIBER ARCHITECTURE GROUP \\ GRUPO DE ARQUITECTURA LIBER \\ GROUPE DE TRAVAIL LIBER \\ SUR L'ARCHITECTURE DES BIBLIOTHÈQUES \\ LIBER ARBEITSGRUPPE BIBLIOTHEKSBAU \\ GRUPPO DI ARCHITETTURA LIBER
}

\begin{abstract}
QUESTIONNAIRE
DESCRIPTION OF NEW UNIVERSITY AND RESEARCH LIBRARY BUILDINGS

IN EUROPE

CUESTIONARIO

DESCRIPCIÓN DE BIBLIOTECAS DE INVESTIGACIÓN Y UNIVERSITARIAS

DE RECIENTE CONSTRUCCIÓN EN EUROPA

QUESTIONNAIRE

SUR LES NOUVEAUX BATIMENTS DE BIBLIOTHEQUES UNIVERSITAIRES

ET DE RECHERCHE EN EUROPE
\end{abstract}

FRAGEBOGEN

NEUE GEBÄUDE VON UNIVERSITÄTSBIBLIOTHEKEN UND WISSENSCHAFTLICHEN BIBLIOTHEKEN

\section{QUESTIONARIO}

DESCRIZIONE NUOVI EDIFICI DI BIBLIOTECHE UNIVERSITARIE E DI RICERCA IN EUROPA 


\section{A GENERAL INFORMATION ABOUT YOUR LIBRARY INFORMACIÓN GENERAL SOBRE SU BIBLIOTECA INFORMATION GENERALE SUR LA BIBLIOTHÈQUE ALLGEMEINE INFORMATION ÜBER DIE BIBLIOTHEK INFORMAZIONI GENERALI SULLA BIBLIOTECA}

a) Name and address

Nombre y dirección

Nom et adresse

Name und Adresse

Nome e indirizzo

1. Type of library:

Tipo de biblioteca:

Type de bibliothèque:

Bibliothekstyp:

Tipo di biblioteca:

2. Name:

Nombre:

Nom:

Name:

Nome:

3. Address:

Dirección:

Adresse:

Adresse:

Indirizzo:

4. Phone, Fax and E-mail numbers:

Teléfono, fax y dirección electrónica:

Numéros de Téléphone, Fax et E-Mail:

Telefon- und Fax-Nummer, E-Mail-Adresse:

Telefono, fax e indirizzo di posta elettronica:

5. Name of the director of the library:

Nombre del director de la biblioteca:

Nom du directeur de la bibliothèque:

Name des Direktors/der Direktorin der Bibliothek:

Nome del direttore della biblioteca: 
6. Person to refer to with inquiries:

Persona de contacto:

Personne à contacter:

Kontaktperson:

Persona da contattare:

\section{b) Population served}

\section{Usuarios}

\section{Population desservie}

Publikum

\section{Utenza}

7. Current readership, number of registered readers:

Número de usuarios registrados:

Nombre de lecteurs inscrits:

Anzahl der eingeschriebenen Benutzerinnen und Benutzer:

Numero di utenti registrati:

8. Number of full time students:

Número de estudiantes de plena dedicación:

Nombre d'étudiants à plein temps:

Anzahl der Vollzeit-Studierenden:

Numero di studenti a tempo pieno:

9. Number of part time students:

Número de estudiantes de dedicación mixta:

Nombre d'étudiants à temps partiel:

Anzahl der Teilzeit-Studierenden:

Numero di studenti a tempo parziale:

10. Number of staff teachers, professors, researchers and administrators:

Número de profesores, asistentes, investigadores y administradores:

Nombre d'enseignants, d'enseignants-chercheurs et d'administratifs:

Anzahl der Dozierenden, Forschenden und der Personen in der Verwaltung:

Numero di docenti, assistenti, ricercatori e personale amministrativo: 
c) Conditions of the library (before the new project)

Condiciones de la biblioteca (anterior al nuevo proyecto)

Situation de la bibliothèque (avant le nouveau projet)

Situation der Bibliothek (vor dem neuen Projekt)

Caratteristiche della biblioteca (prima del nuovo progetto)

11. Total floor area (sq. metres):

Superficie total en metros cuadrados:

Superficie totale (en mètres carrés):

Gesamtfläche (in $\mathrm{m}^{2}$ ):

Superficie totale (in $\mathrm{m}^{2}$ ):

12. Number of reader seats:

Número de asientos:

Nombre de places de consultation:

Anzahl Benutzerarbeitsplätze:

Numero di posti di lettura:

13. Total Capacity of shelving (linear meters or volumes of books and periodicals):

Capacidad total de almacenaje (metros lineales o número de volúmenes y revistas):

Capacité totale de stockage (en mètres linéaires ou en volumes de livres et de périodiques):

Gesamt Kapazität Stellfläche (Laufmeter oder Anzahl Bände von Büchern und Zeitschriften):

Capacità di stivaggio (espressa in metri lineari o numero di libri e periodici):

Divided into / dividido entre / divisée en / unterteilt in / divisa in:

14. in open access storage:

en estanterías de acceso libre:

collections en libre accès:

in Freihand-Aufstellung:

a scaffale aperto:

15. in closed access stacks:

en estanterías de acceso restringido:

collections en magasins fermés:

in geschlossenen Magazinen:

a magazzino: 
16. Number of staff (full time equivalent):

Personal (el número equivalente a personas con jornada completa):

Nombre de personnel (équivalents plein temps):

Anzahl Beschäftigte (Vollzeit-Aequivalente):

Unità di personale (espresso in full time equivalent):

17. Opening hours to the public (hours per week and days per year):

Horarios de apertura (horas a la semana y días al año):

Ouverture au public (nombre d'heures par semaine et de jours par an):

Oeffnungszeiten (Stunden pro Woche und Tage pro Jahr):

Orario di apertura (espresso in ore di apertura settimanali e in numero di giorni per anno):

B THE NEW BUILDING: AIMS AND FEATURES

EL NUEVO EDIFICIO: PROPÓSITOS Y CARACTERÍSTICAS

LE NOUVEAU BATIMENT: BUTS ET CARACTERISTIQUES

DAS NEUE GEBÄUDE: ZIELE UND EIGENSCHAFTEN

IL NUOVO EDIFICIO: OBIETTIVI E CARATTERISTICHE

a) Architect(s)

Arquitecto(s)

Architecte(s)

Architekt(en)

Architetto(i)

18. Firm:

Despacho:

Agence:

Büro:

Studio:

19. Project Architect:

Arquitecto del proyecto:

Chef de projet:

Projektleiter/in:

Architetto progettista: 
20. Type of project

Tipo de proyecto

Type de projet

Art des Projektes

Tipo di progetto

$\begin{array}{lll}\text { New building: } & \text { yes } & \text { no } \\ \text { Nuevo edificio: } & \text { si } & \text { no } \\ \text { Construction: } & \text { oui } & \text { non } \\ \text { Neubau: } & \text { ja } & \text { nein } \\ \text { Nuovo edificio: } & \text { si } & \text { no } \\ \text { Extension: } & & \\ \text { Ampliación: } & \text { yes } & \text { no } \\ \text { Extension: } & \text { si } & \text { no } \\ \text { Erweiterung: } & \text { oui } & \text { non } \\ \text { Ampliamento: } & \text { ja } & \text { nein } \\ & \text { si } & \text { no } \\ \text { Renovation: } & & \\ \text { Rehabilitación: } & \text { yes } & \text { no } \\ \text { Aménagement: } & \text { si } & \text { no } \\ \text { Renovation: } & \text { oui } & \text { non } \\ \text { Restauro: } & \text { ja } & \text { nein } \\ & \text { si } & \text { no }\end{array}$

b) Aims of the new building

Propósitos del nuevo edificio

Buts du nouveau bâtiment

Ziele des neuen Gebäudes

Obiettivi del nuovo edificio

21. Short description of the main objectives and purposes of the project:

Breve descripción de los principales objetivos y propósitos del proyecto:

Courte description des principaux objectifs du projet:

Kurze Beschreibung der Hauptziele und Absichten des Projektes:

Breve descrizione dei principali obiettivi del progetto:

for example:

por ejemplo:

par exemple:

zum Beispiel:

per esempio: 
more holdings in open stacks,

más volúmenes en las zonas de acceso libre, davantage de documents en libre accès, grössere Bestände in Freihand-Aufstellung,

maggior numero di documenti ad accesso libero

more readers seats,

más asientos,

davantage de places de consultation,

mehr Benutzerarbeitsplätze,

più posti di lettura,

development of the library in the field of research,

desarrollo de la biblioteca en el campo de la investigación,

développement de la bibliothèque dans le domaine de la recherche,

Ausbau der Bibliothek im Bereich Forschung,

maggior sviluppo della biblioteca verso la ricerca,

computer and audiovisual materials,

Informática y materiales audiovisuales,

documents informatiques et audiovisuels,

EDV und AV-Material,

documentazione elettronica e audiovisivi,

development of training for non-student readers,

desarrollo y aprendizaje para usuarios no estudiantes,

formation des lecteurs non étudiants,

Schulung von nichtuniversitärem Publikum,

sviluppo di un utenza non istituzionale,

extension of the opening hours to the public, etc.

ampliación de las horas de apertura al público, etc.

extension des horaires d'ouverture de la bibliothèque, etc.

Erweiterung der Oeffnungszeiten der Bibliothek, etc.

Estensione degli orari di apertura, ecc. 


\section{c) Special Features}

\section{Características especiales}

Caractéristiques

Spezielle Merkmale

\section{Caratteristiche}

22. Site:

Emplazamiento:

Localisation, site:

Ort:

Localizzazione:
for example:
por ejemplo:
par exemple:
zum Beispiel:
per esempio:

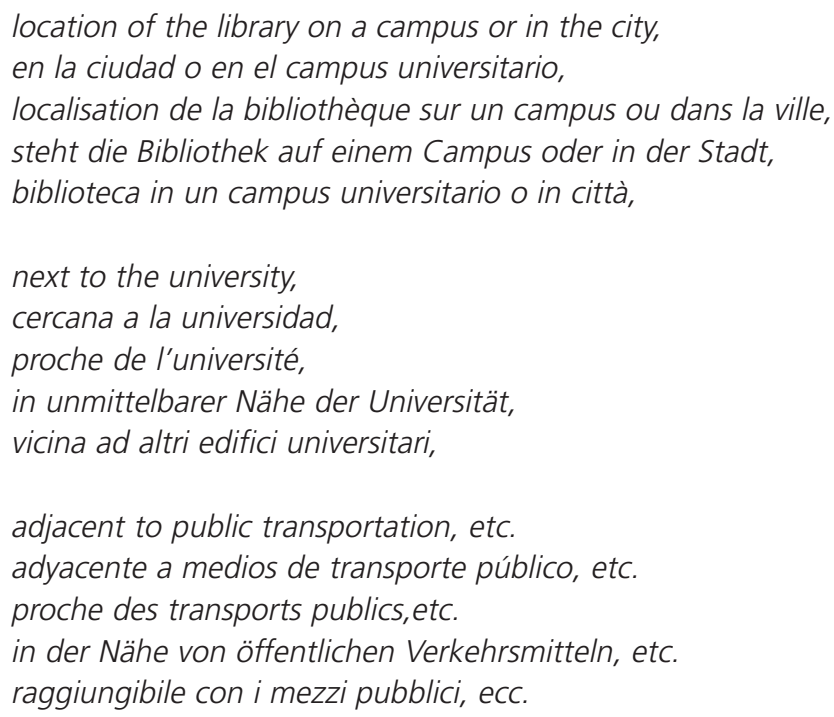

23. Architecture:

Arquitectura:

Architecture:

Architektur:

Architettura: 
for example:

por ejemplo:

par exemple:

zum Beispiel:

per esempio:

rectangular or octogonal plan,

plan rectangular u octogonal,

plan rectangulaire ou octogonal,

rechteckiger oder vieleckiger Grundriss,

a pianta rettangolare o ottagonale,

precast concrete pannels,

paneles de hormigón prefabricado,

panneaux préfabriqués en béton,

vorgefertigte Betonelemente,

a pannelli prefabbricati,

narrow or high windows, sizes of the modular grid,

ventanas estrechas o altas, tamaños de la red modular,

façades très vitrées ou peu vitrées, dimensions de la trame de construction,

schmale oder hohe Fenster/stark oder wenig verglaste Fassaden, Maße des Konstruktionsrasters:

finestre strette o alte, dimensioni dello schema strutturale,

disabled access,

condiciones de accesibilidad,

accès pour handicapés,

Zugang für Behinderte,

accesso ai disabili,

materials selected to reduce maintenance costs, etc.

materiales seleccionados para reducir los costes de mantenimiento, etc.

matériaux utilisés pour réduire les coûts de maintenance, etc. Wahl der Baumaterialien mit der Absicht, die Unterhaltskosten zu reduzieren, etc.

utilizzo di materiali che riducano i costi di manutenzione, 


\section{TECHNICAL INFORMATION ABOUT THE NEW BUILDING INFORMACIÓN TÉCNICA SOBRE EL NUEVO EDIFICIO INFORMATIONS TECHNIQUES SUR LE NOUVEAU BATIMENT TECHNISCHE INFORMATION ÜBER DAS NEUE GEBÄUDE INFORMAZIONI TECNICHE SUL NUOVO EDIFICIO}

a) Please give floor area (in sq metres) for questions 22 to 33 Por favor faciliten la superficie por plantas en metros cuadrados en las preguntas 22 a 33

Indiquer la surface (en mètres carrés) pour les questions 22 à 33 Gesamtfläche (in $\mathrm{m}^{2}$ ) für die Fragen 22 bis 33

Rispondere indicando la superficie in $\mathrm{m}^{2}$ alle domande da 22 a 33

24. Total gross floor area (including corridors, stairs, lifts, technical rooms, etc): Superficie total (incluyendo pasillos, escaleras, elevadores, salas de máquinas, etc.):

Surface totale dans œuvre (incluant les circulations, sanitaires et locaux techniques):

Netto-Grundfläche (inkl. Korridore, Treppen, Aufzüge, technische Räume etc.): Superficie totale (inclusi corridoi, scale, ascensori, locali tecnici, ecc.):

Divided into / dividido entre / divisé en / unterteilt in / divisa in:

25. Open access services (reference room, reading rooms, holdings - books and periodicals -, circulation and information desks, etc.):

Servicios de acceso libre (salas de lectura, salas de índices, salas de publicaciones, información, etc.):

Services en libre accès (références, consultation, collections de livres et de périodiques, bureaux d'information et de prêt, etc):

Frei zugängliche Benutzungsbereiche (Auskunftsräume, Lesesäle, Buch- und Zeitschriftenbestände, Ausleihe, Information, etc.):

Aree ad accesso libero (reference, sale di lettura, sale di consultazione libri e periodici, punti informativi e di prestito, ecc.):

Special rooms for (please describe number 26, 27, 28, 29):

Salas especiales para (por favor, describa el número 26, 27, 28, 29):

Salles spéciales pour (SVP, décrire les salles 26, 27, 28, 29 ):

Spezielle Räume für (Bitte beschreiben Sie die Räume in Nr. 26, 27, 28, 29):

Sale ad uso speciale per (per la descrizione utilizzare i numeri 26, 27, 28, 29): 
26. Audiovisual:

Audiovisuales:

Audiovisuel:

audiovisuelle Medien:

Audiovisivi:

27. Computers:

Ordenadores:

Informatique:

Computer:

Postazioni informatiche:

28. Special collections:

Colecciones especiales:

Collections spécialisées:

Sondersammmlungen:

Collezioni particolari:

29. Seminar room(s):

Sala(s) de seminarios:

Salle(s) de formation/réunion:

Ausbildungs- und Seminarraum (-räume):

Sale seminariali:

Special activities (please describe number 30, 31, 32)

Actividades especiales (por favor, describa el número 30, 31, 32)

Salles pour autres activités (SVP, décrire les salles 30, 31, 32)

Räume für andere Aktivitäten (Bitte beschreiben Sie die Räume in Nr. 30, 31, 32)

Attività speciali (per la descrizione utilizzare i numeri 30, 31, 32):

30. Exhibition space:

Espacio para exhibiciones:

Espace d'exposition:

Ausstellungsraum:

Spazi espositivi:

31. Lecture hall:

Sala de conferencias:

Salle de conférence:

Vortragssaal:

Sala conferenze: 
32. Public refreshments:

Sala de ocio:

Cafétéria, etc:

Cafeteria, etc:

Caffetteria:

33. Administration and staff areas:

Zonas de personal y de administración:

Services internes pour le personnel:

Räume für Verwaltung und Personal:

Spazi dedicati al personale:

34. Closed access stacks:

Estanterías de acceso restringido:

Magasins fermés:

Geschlossene Magazinräume:

Magazzini chiusi al pubblico:

35. Circulations areas (corridors, stairs, lifts), toilets, technical rooms, etc:

Zonas de circulación (pasillos, escaleras, elevadores), aseos, salas de máquinas, etc.:

Zones de circulation (couloirs, escaliers, ascenseurs), sanitaires, locaux techniques, etc.:

Nebennutzfläche: Verkehrsfläche (Korridore, Treppen, Aufzüge), Toiletten, technische Räume, etc.:

Collegamenti verticali e orizzontali (corridoi, scale, ascensori), servizi igienici, locali tecnici:

36. Further information (eg. Number of levels, public levels, etc.):

Más información (número de plantas públicas, etc.):

Autres informations (par ex.: nombre total de niveaux, nombre de niveaux publics, etc.):

Weitere Informationen (z.B. Anzahl Stockwerke, Anzahl öffentliche Stockwerke, etc.):

Altri dati (es. numero di piani, numero di piani accessibili al pubblico, ecc.):

37. Number of reader seats (Total):

Número de asientos (Total):

Nombre de places de lecture (Total):

Anzahl Benutzerarbeitsplätze (Total):

Numero di posti di lettura (totale): 
Divided into / dividido entre / divisé en / unterteilt in / diviso in:

38. Audiovisual:

Audiovisuales:

Audiovisuel:

audiovisuelle:

Postazioni per gli audiovisivi:

39. Computers:

Ordenadores:

Informatique:

Computer:

Postazioni informatiche:

40. Seminar room(s):

Sala(s) de seminarios:

Salle(s) de formation/réunion:

Ausbildungs- und Seminarraum (-räume):

Sala/e seminari:

41. Regular:

Resto:

Places de travail:

übrige Benutzerarbeitsplätze:

Postazioni di lavoro:

b) Total potential capacity of shelving (linear metres or volumes)

Capacidad potencial de almacenaje (metros lineales o volúmenes)

Capacité potentielle totale de stockage (mètres linéaires ou volumes)

Gesamtkapazität Stellfläche (Laufmeter oder Bände)

Capacità massima di stoccaggio (espressa in metri lineari o volumi)

42. Books and periodicals:

Libros y publicaciones:

Livres et périodiques:

Bücher und Zeitschriften:

Libri e periodici:

Divided into / dividido entre / divisé en / unterteilt in / divisi in: 
43. Open access stacks:

Estanterías de acceso libre:

En libre accès:

Freihand-Aufstellung:

a scaffale aperto:

44. Closed access stacks:

Estanterías de acceso restringido:

En magasins fermés:

geschlossene Magazine:

a magazzino:

45. within compact shelving:

en compactos:

dont en rayonnages mobiles:

davon Kompakt-Magazine:

in scaffali compatti:

46. Audiovisual materials:

Materiales audiovisuales:

Documents audiovisuels:

audiovisuelle Materialien:

Materiale audiovisivo:

47. Other:

Otros:

Autres:

Andere:

Altro:

48. Number of staff required for the functioning of the new library (full time equivalent):

Número de empleados requeridos para el funcionamiento de la nueva biblioteca (equivalente a personas con jornada completa):

Nombre de personnel nécessaire pour faire fonctionner la nouvelle bibliothèque (équivalent plein temps):

Personal, das für den Betrieb des neuen Gebäudes benötigt wird (VollzeitAequivalente):

Personale necessario per il funzionamento della nuova biblioteca (espresso in full time equivalent): 
c) Mechanical features

Características técnicas

Caractéristiques techniques

Mechanische Eigenschaften

Caratteristiche tecniche

49. Ventilation/Air Conditioning:

Ventilación/Aire acondicionado:

Ventilation/Climatisation:

Lüftung/Klimatisierung:

Sistema di climatizzazione:

50. Heating:

Calefacción:

Chauffage:

Heizung:

Sistema di riscaldamento:

51. Lighting:

lluminación:

Eclairage:

Beleuchtung:

Illuminazione:

52. Acoustics:

Megafonía:

Acoustique:

Akustik:

Acustica:

53. Lifts, elevators, escalators:

Elevadores, montacargas, escaleras:

Ascenseurs, monte-charges, escalators:

Aufzüge, Rolltreppen:

Ascensori, montacarichi, scale:

54. Book transportation system:

Sistema de transporte de libros:

Système de transport automatique de documents:

Buchtransportsystem:

Sistemi di trasporto dei libri: 
55. Theft detection:

Sistema antirrobo:

Détection antivol:

Diebstahl-Sicherungssystem:

Sistema Antitaccheggio:

56. Computerised house control:

Control informatizado del edificio:

Gestion informatisée du bâtiment:

informatisierte Gebäudetechnik:

Gestione computerizzata dell'edificio:

57. Type of IT-cabling and capacity:

Tipo y capacidad del cableado informático:

Type de câblage informatique et débit du réseau:

Typ der IT-Verkablung und Leistung:

Tipo e capacità di cablaggio:

58. Other:

Otros:

Autres:

Andere:

Altro:

D SCHEDULE OF THE BUILDING PROCESS

CALENDARIO

ECHEANCIER DE REALISATION

ZEITPLAN

TEMPI DI REALIZZAZIONE DEL NUOVO EDIFICIO

59. Planning, preliminary brief:

Planteamiento, borradores iniciales:

Elaboration du programme:

Planung, Bauprogramm:

Elaborazione del programma:

60. Architectural competition:

Concurso Arquitectónico:

Concours d'architecture:

Architekturwettbewerb:

Concorso per la progettazione: 
61. Project drawings and competition between contractors:

Planos y concurso de las empresas constructoras:

Elaboration des plans et appel d'offres aux entreprises:

Architekturpläne und Ausschreibung für ausführende Firmen:

Progettazione e gara di appalto per la nomina della ditta esecutrice:

62. Opening of the construction work:

Fecha de inicio de las obras:

Démarrage des travaux:

Beginn der Bauarbeiten:

Apertura del cantiere:

63. Duration of the building work:

Duración de las obras:

Durée des travaux:

Dauer der Bauarbeiten:

Durata del cantiere:

64. Furnishing and moving the collections:

Traslado de los volúmenes:

Equipement mobilier et déménagement:

Einrichtung Mobiliar und Umzug der Bestände:

Allestimento arredi e trasloco delle collezioni:

65. Date of opening of the new building:

Fecha de apertura del nuevo edificio:

Date d'ouverture du bâtiment:

Datum der Eröffnung des neuen Gebäudes:

Data di apertura del nuovo edificio:

\section{E COSTS}

\section{COSTES}

COÛTS

KOSTEN

COSTI

66. Site:

Solar:

Terrain:

Grundstück:

Terreno: 
67. Building:

Edificación:

Bâtiment:

Gebäude:

Edificio:

68. Furniture and equipment:

Equipamientos y mobiliario:

Equipement en mobilier et en matériel:

Mobiliar und Ausrüstung:

Arredi e attrezzature:

69. Fees:

Tasas:

Honoraires:

Honorare:

Onorario:

70. Total:

Total:

Total:

Total:

Totale:

F PUBLICATIONS:

PUBLICACIONES:

PUBLICATIONS:

VERÖFFENTLICHUNGEN:

PUBBLICAZIONI:

THE QUESTIONNAIRE HAS TO BE ACCOMPANIED BY:

- Plans (of the different levels, sections and façades) and drawings: one page in pdf-format per level. What is needed are the final designs, presented in a simplified way, with a graphical linear scale and with a reference number for each area or service.

- Captions (name of the library, name of the architect(s), level numbering), must be clearly mentioned on each page in the pdffile, with a title for each reference number concerning the different areas. 
- Four or five photographs of the building, or of the model if the building is under construction; the photos must be delivered in jpgformat.

- Any plans, drawings and photographs supplied may be published in the documentation without fee.

THANK YOU! 


\section{Cambridge University Library -}

\section{Legal Deposit and University Library}




\section{A GENERAL INFORMATION ABOUT THE LIBRARY}

a) Name and address

1. Legal Deposit and University Library

2. Cambridge University Library

3. West Road, Cambridge, CB3 9DR

4. Phone: (0)1223 333000

Fax: (0)1223 333160

E-mail: library@lib.cam.ac.uk

5. Peter Fox

6. Richard Hardy

b) Population served

7. 35000

8.+9. 18000

10. 4700

c) Conditions of the library (before the new project)

11. $18400 \mathrm{sq} \mathrm{m}$

12. 900

13. $130 \mathrm{~km}$

14. $20 \%$

15. $80 \%$

16. 280

17. 60 hours/week, 302 days/year

\section{B THE NEW BUILDING: AIMS AND FEATURES}

a) Architect(s)

18. The Howe Partnership

Milburn house,

Dean Street

Newcastle upon Tyne NE1 1LF

Tel (0)1912816795

19. Christine Howe

20. Extension: yes

Renovation: yes 


\section{b) Aims of the new building}

21. The University Library, as a Legal Deposit Library, has a need to house an ever-increasing book collection. In the late 1980s this need gave rise to a feasibility study on ways to not only increase that storage, but improve conditions for the collections' preservation and the facilities for users of the Library. Subsequently a major programme of extensions and alterations was devised.

\section{c) Special Features}

22. Situated to the West of the river in Cambridge, the University Library is easily reached from the central colleges and faculties by footpaths and cycleways, or the University funded public bus service run between the more outlying areas of the University.

23. The extensions were carried out in the style of the original 1934 design by Sir Giles Gilbert Scott. An extract from his description of the new Library at that time gives an indication of his thoughts.

"My aim has been to produce a quiet, dignified building, relying for effect upon its main lines rather than upon elaboration of detail ... The building has been designed to express its function, rather than to obscure this by superficial features and enrichments. The characteristic lighting of a modern bookstack, with its long vertical windows, has been taken as a key to the whole design, and as these features appear throughout most of the building, they impart a distinctive character, not without architectural qualities."

It is considered the sympathetic interpretation in modern materials has continued that view, while the introduction of suitable environmental systems improves the preservation of collections. Facilities for users of the Library were considerably improved, with the building of replacement reading rooms for Manuscripts and Rare Books, Digital resources areas and the addition of a new, donation funded, reading room for the East Asian collections. Our attention to facilities for less able users includes new access lift to the front in the original façade and a new, large, staffed entrance where assistance is available and ease of entrance is assured. 


\section{TECHNICAL INFORMATION ABOUT THE NEW BUILDING}

a) Floor area (in sq metres) for questions 24 to 33

\section{4-35. 11700}

36. 6 levels with public access to 3 levels

37. 345 with an additional 100 in the seminar rooms

38. 61

39. 68

40. 6

41. 210

b) Total potential capacity of shelving (linear metres or volumes)

42. $1442 \mathrm{~m}$

43. 0

44. $1442 \mathrm{~m}$

45. $80 \%$

46. 2 additional staff

\section{c) Mechanical features}

49-50. The building extensions were designed to be suitable for the archival storage of collections ranging from modern materials to rare books and manuscripts. Conditions are controlled by a central building services system and range from temperature control, both heating and cooling and humidity for the stacks and users' facilities, to controls intended to reduce exposure of collections to light. Plant is situated both in basement and roof area plantrooms and spaces.

51. Mainly fluorescent uplighting to reading rooms, high efficiency low energy. High frequency ballast fluorescent lights for general office areas.

52. No special features

53. Lifts are provided to all floors, numbering six in recent extensions detailed. Several were refurbished in the original areas.

54. No book transportation facilities are installed.

55. confidential

56. see 49 above

57. Cat5E are wireless connection to intranet and internet on protected facilities. Central server based cataloguing services operated and maintained from the University Library. 


\section{SCHEDULE OF THE BUILDING PROCESS}

The recent extensions to the University Library consist of stages II and III. (Stage I was built 1959-1963 and is not applicable to this report.) Stage II was completed in 1993 and the stage III in six phases, from 1998 to 2005 (phases 1-5) with one remaining phase (6) to be commenced when funding is secured.

Stage II

Rotherham Building and Courtyards in 1993 cost $\mathrm{f} 3.28$ million

The specialist library functions such as workshops, conservation, bindery and the cafeteria were moved from the courtyard peripheral rooms to a new basement and two storey wing, The Rotherham Building. The courtyards were roofed over and this, together with the space vacated was used to house one million books.

Stage III

Phase 1

Aoi Pavilion and West Bookstacks basement in 1998 cost $f 7.4$ million An extension formed the Aoi Wing of basement and two floors, provided by donation from Mr Tadao Aoi, mainly to house the East Asian collections. This was carried out concurrently with the forming of the basement area to the planned, new West Bookstack.

Phase 2

Entrance and Exhibition Centre in 1998 cost $f$ 900,000

An internal refurbishment of part of the ground floor, forming a new Exhibition Centre and seminar rooms, together with a refurbishment and upgrade of the entrance hall and cloakroom facilities.

Phase 3

North West corner Extension in 2001 cost $\mathrm{f} 5.7$ million

The demolition of part of the 1970 extension with the creation of a new and much extended wing of four floors, to house Imaging Services, Rare Books and Manuscripts, including reading rooms and offices. 
Phase 4

South West corner Extension in 2003 cost $f 6$ million

The demolition of a further part of the 1970 extension with the creation of a new and much extended wing of four floors, to house Administration, Inter library Loans, and the Official Publications and Microform Reading rooms and a new Digital Resources Area.

Phase 5

West Bookstacks (northern half) in 2005 cost $\mathrm{f} 5.7$ million

The provision of additional storage, five floors of secure archive to BS 5454 standards.

Phase 6

West Bookstacks (southern half) to be built as an almost exact copy of phase 5 .

(Note that the Site Plan appended indicates a current, internal project of refurbishment and replacement bookstacks in the 1970s extension, with a three year timescale)

\section{E COSTS}

There were no costs associated with the purchase of the site, being already owned by the University. Costs for each phase are indicated in the text. 


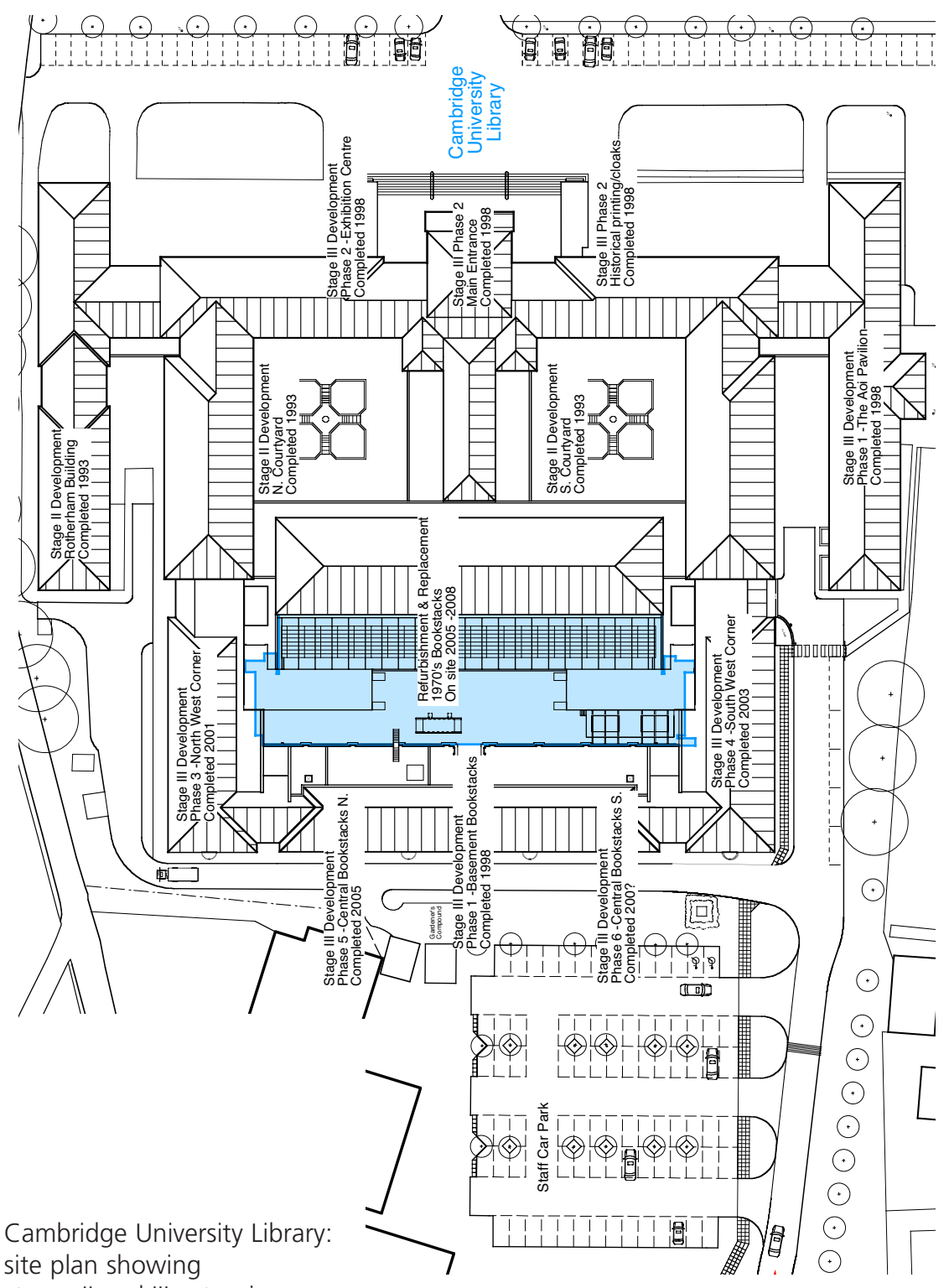

stages II and III extensions

Plans: Courtesy of The Howe Partnership 


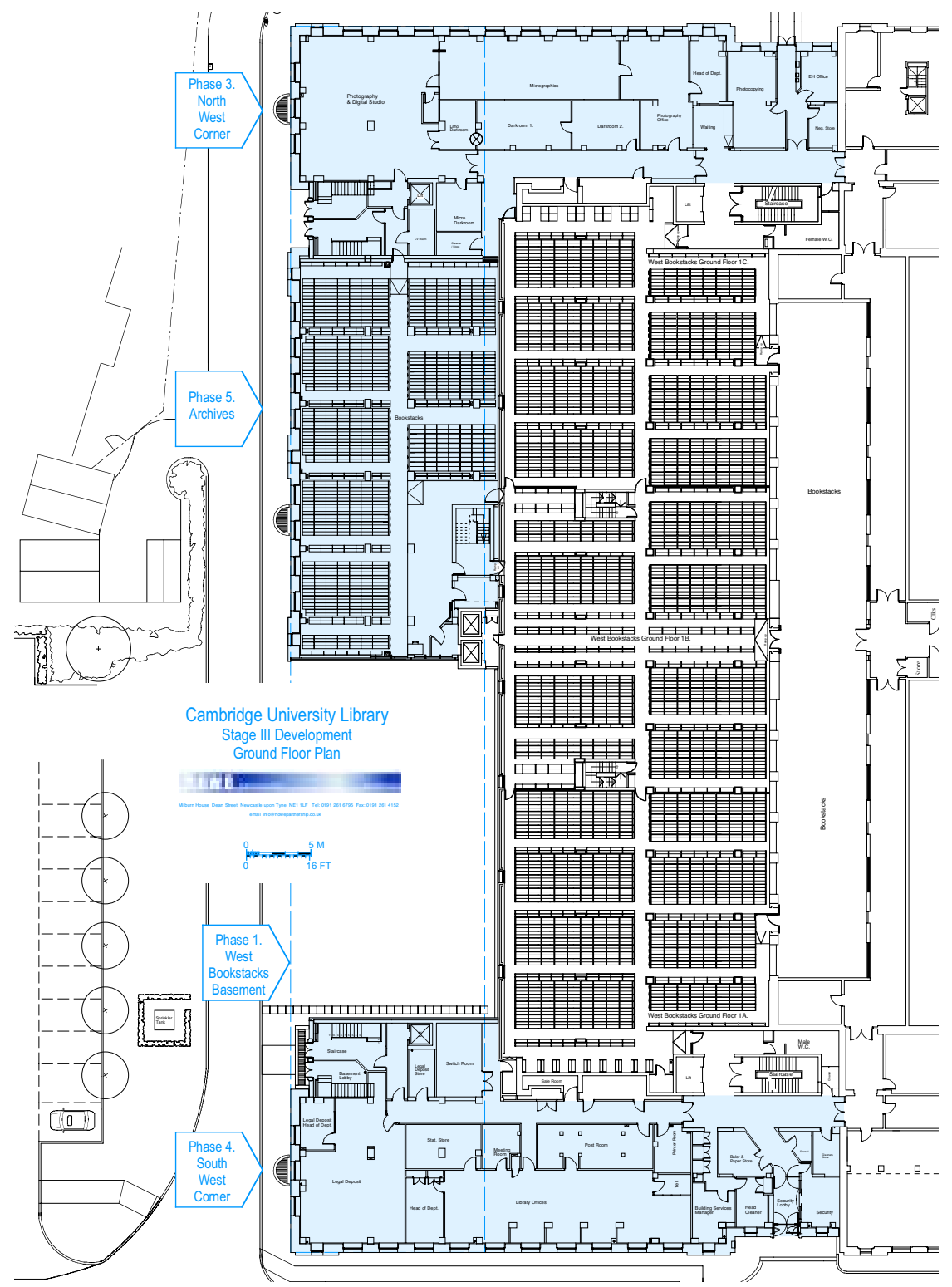

Cambridge University Library:

site plan showing stage III, phases 1, 3, 4 and 5 (ground floor)

Plans: Courtesy of The Howe Partnership 


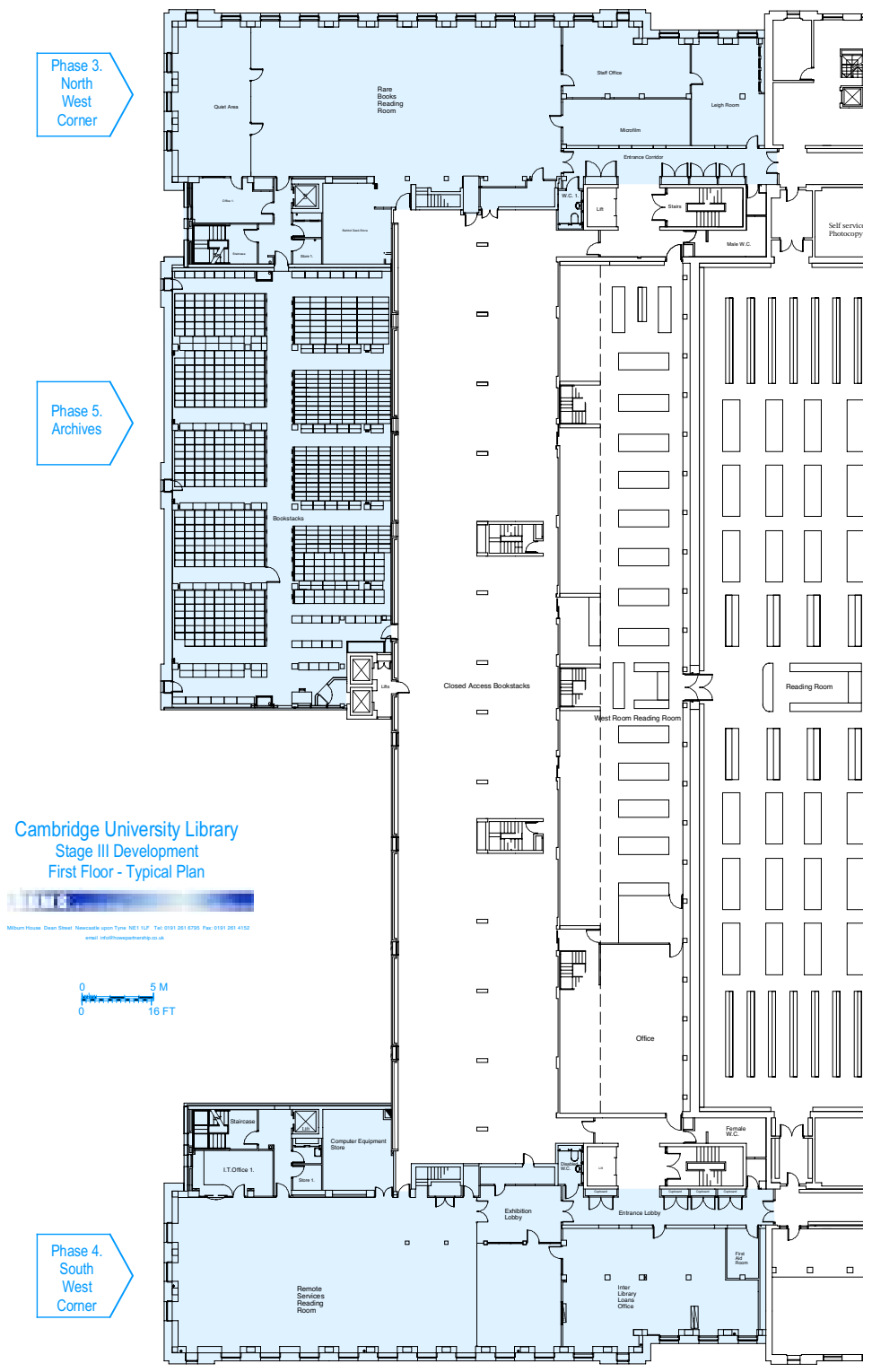

Cambridge University Library:

site plan showing stage III, phases 3, 4 and 5 (first floor)

Plans: Courtesy of The Howe Partnership 


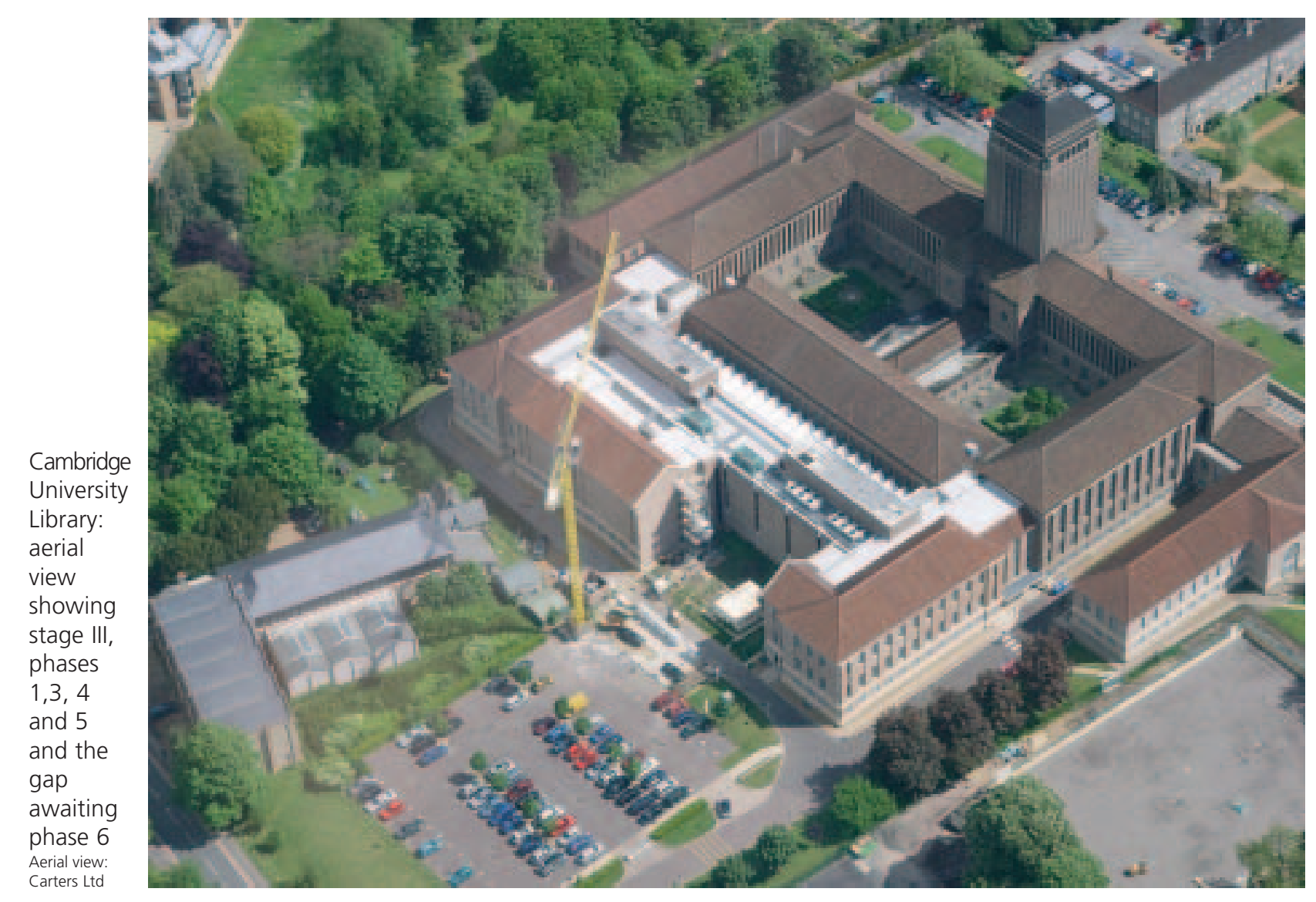


Cambridge University Library: stage III, phase 3

(exterior) Photograph:

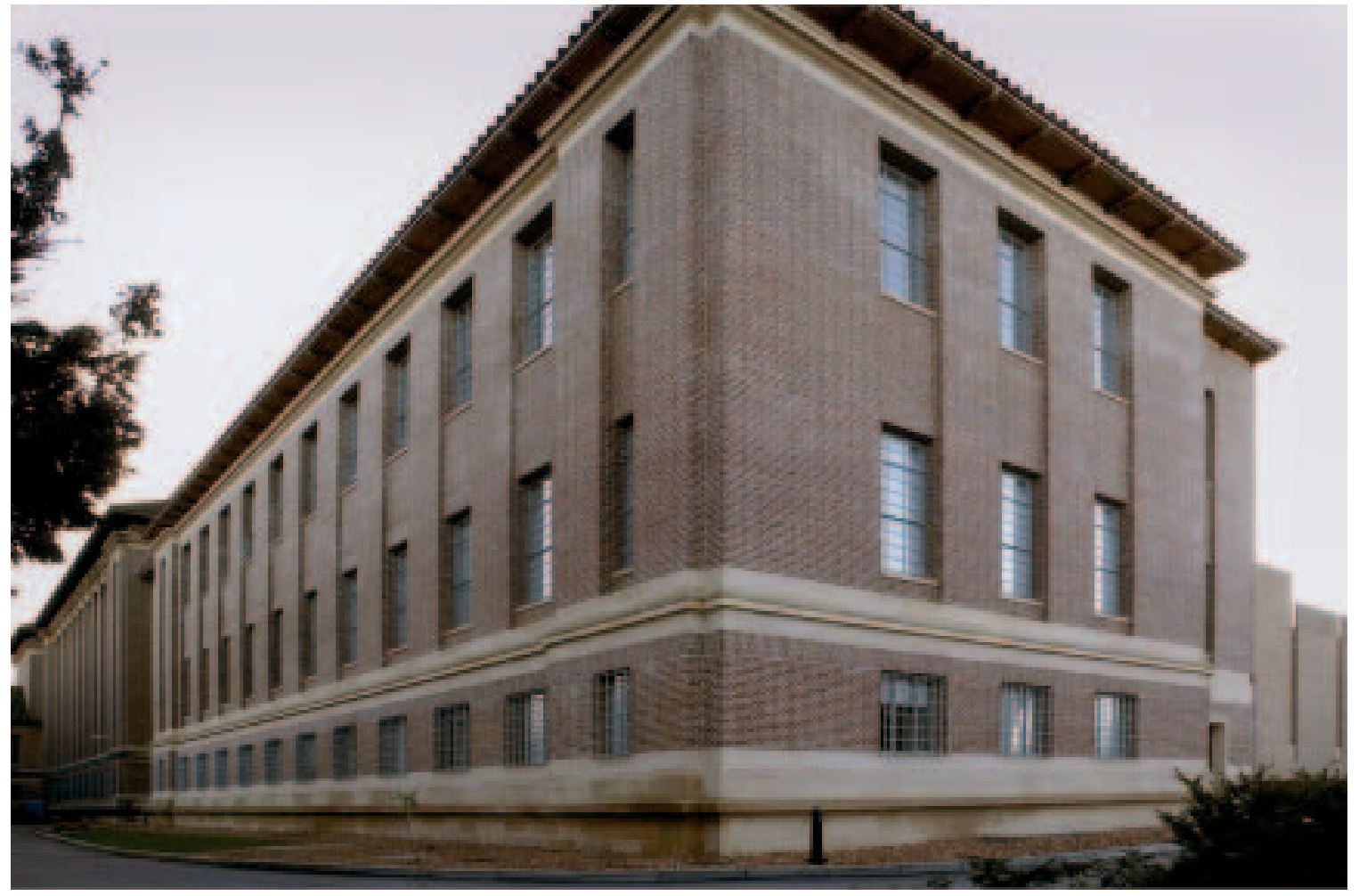




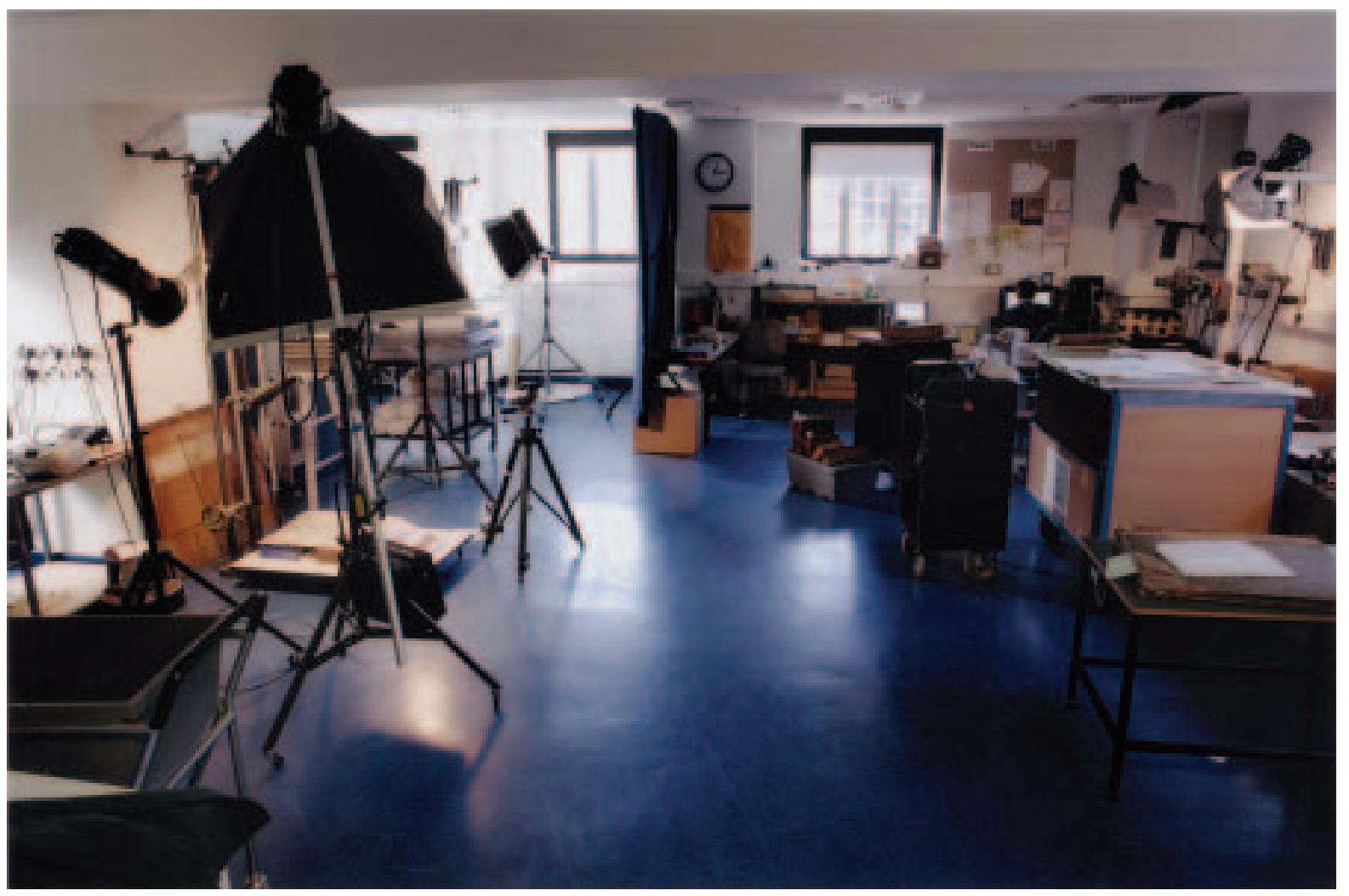

Cambridge University Library:

stage III, phase 3, ground floor (Photography and Digital Imaging Studio) Photograph: Nick Carter 


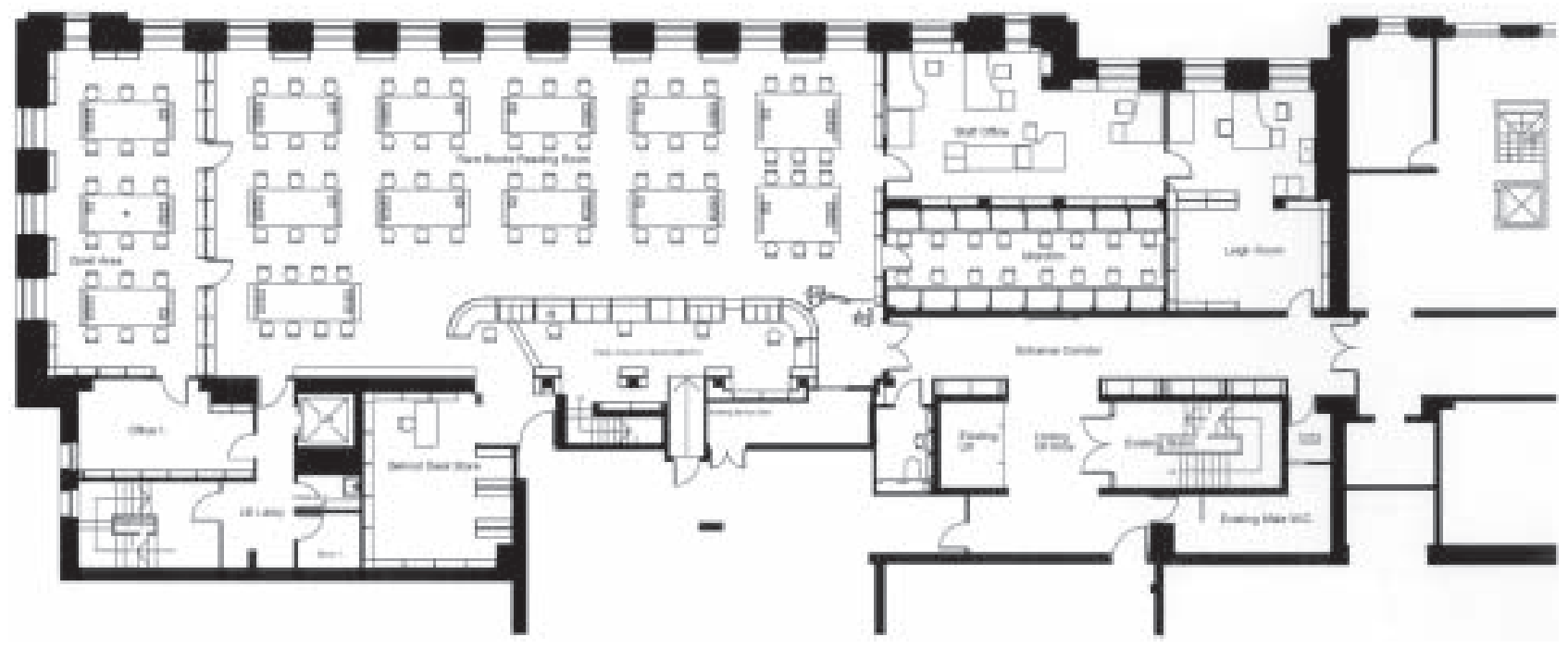




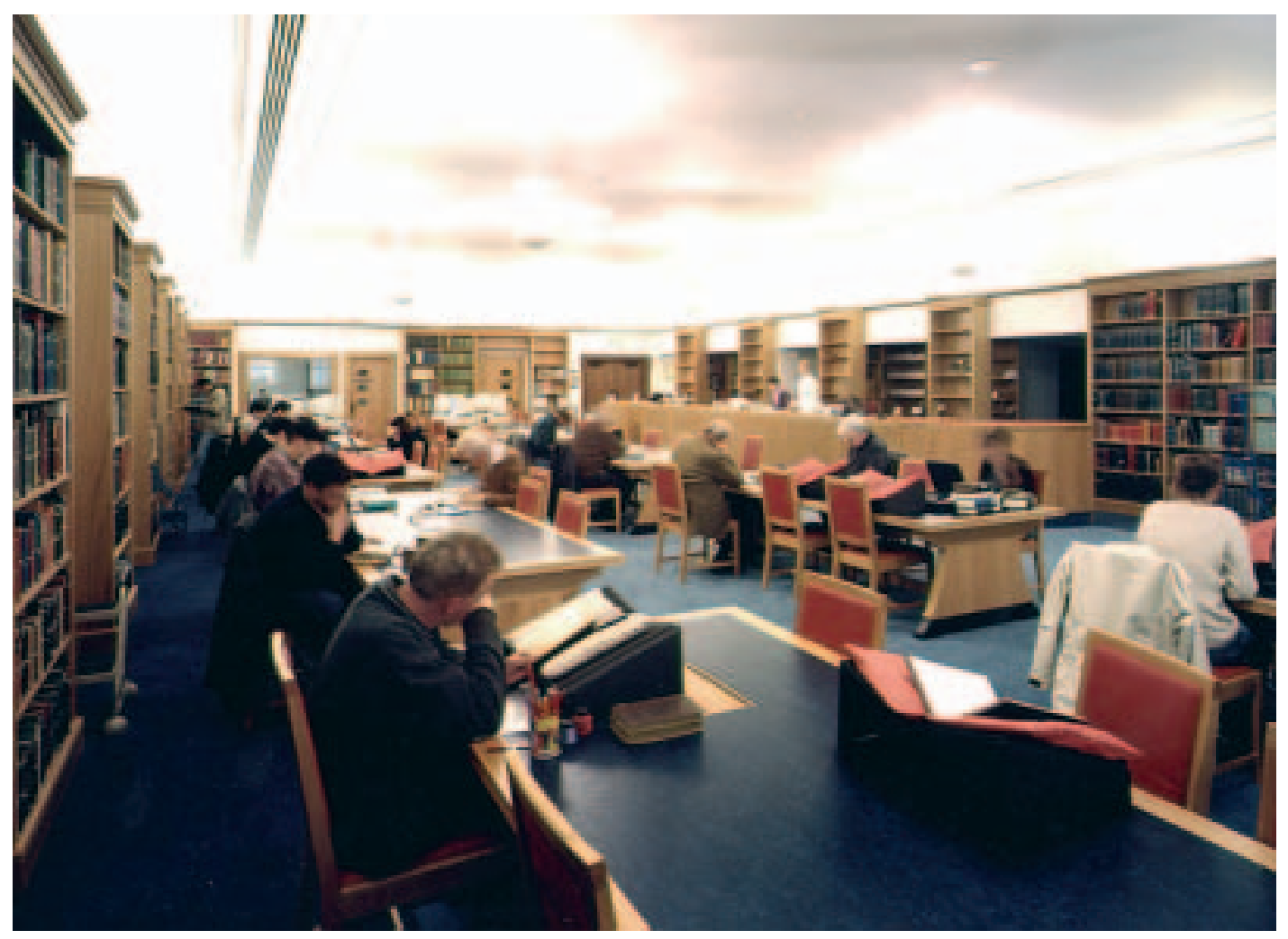

Cambridge University Library:

stage III, phase 3, first floor (Rare Books Reading Room) 


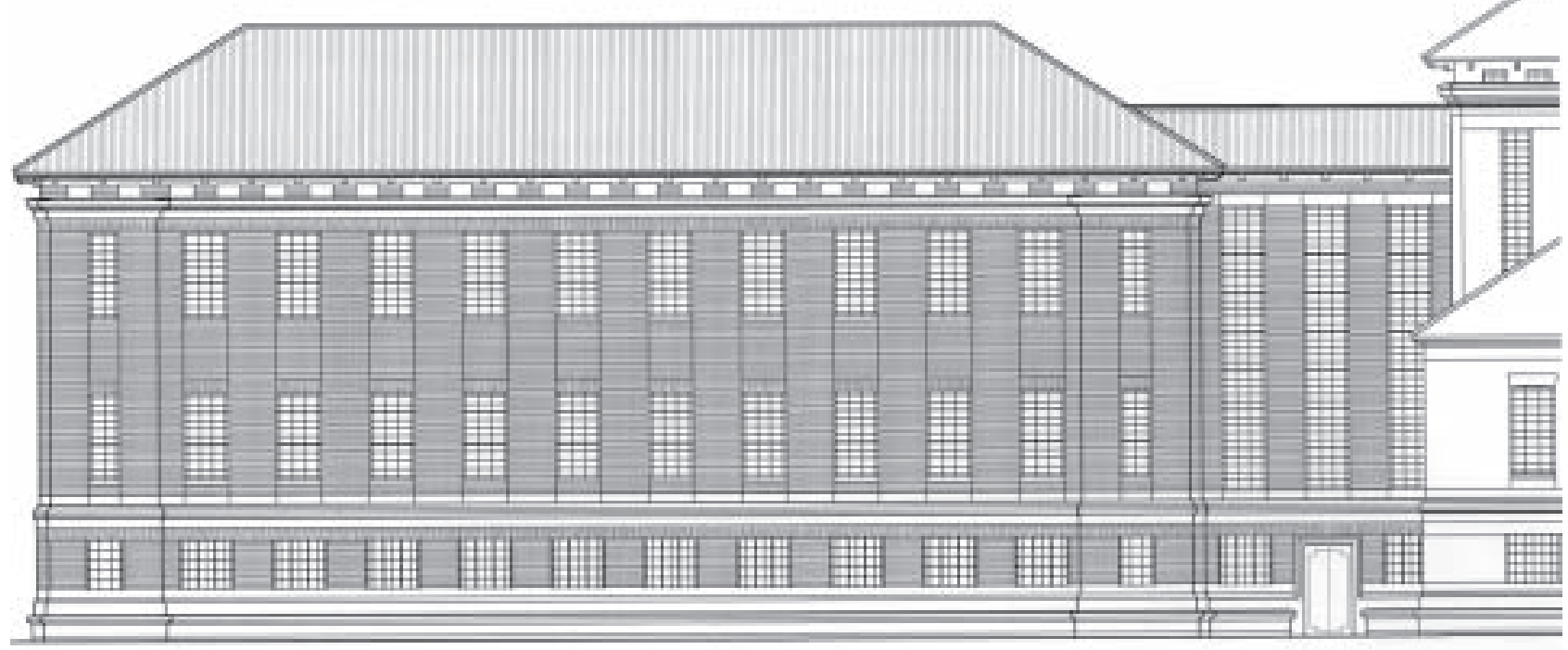




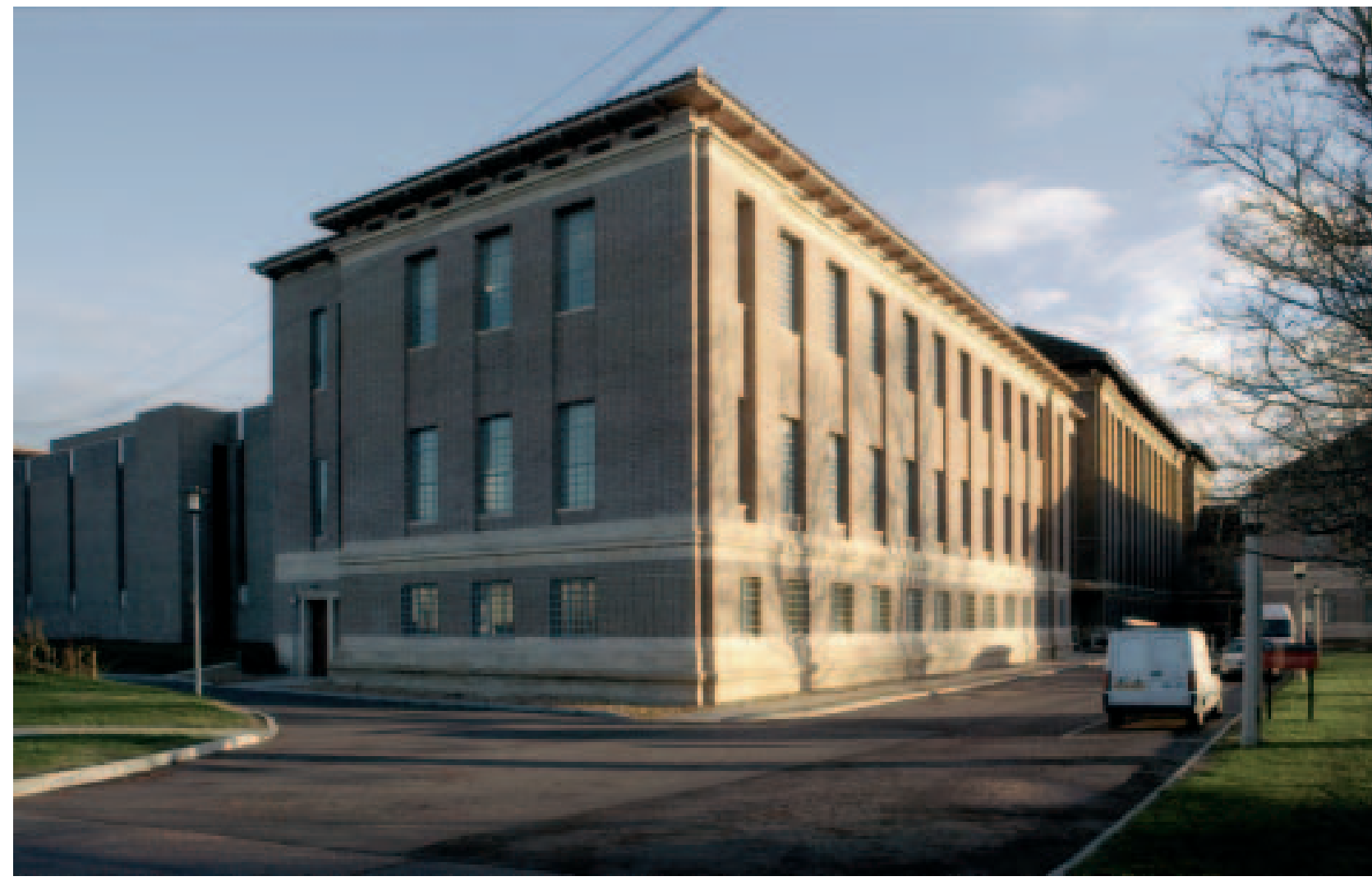




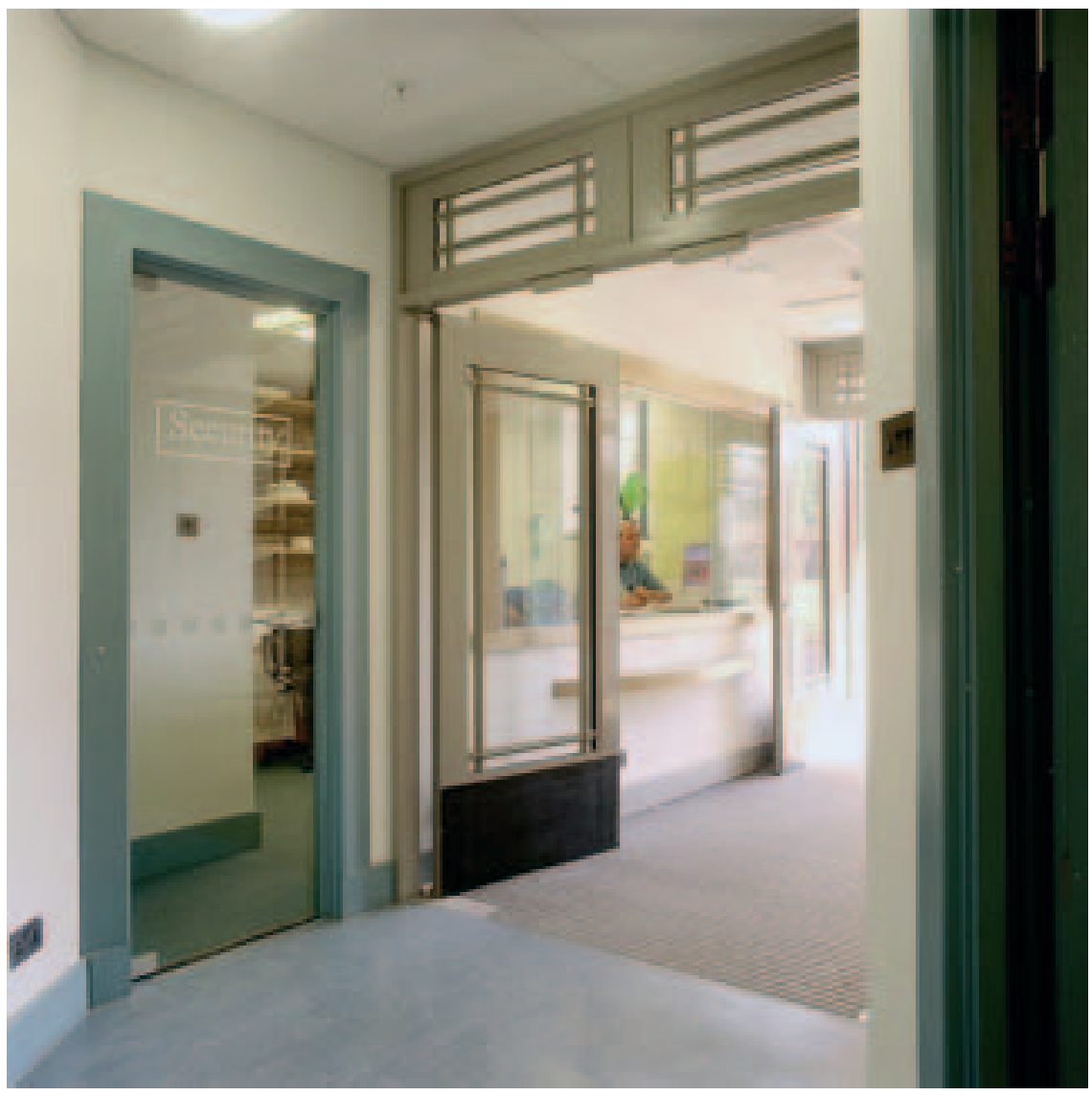

Cambridge University Library:

stage III, phase 4, ground floor (Staff entrance and security office) Photograph: Nick Carter 


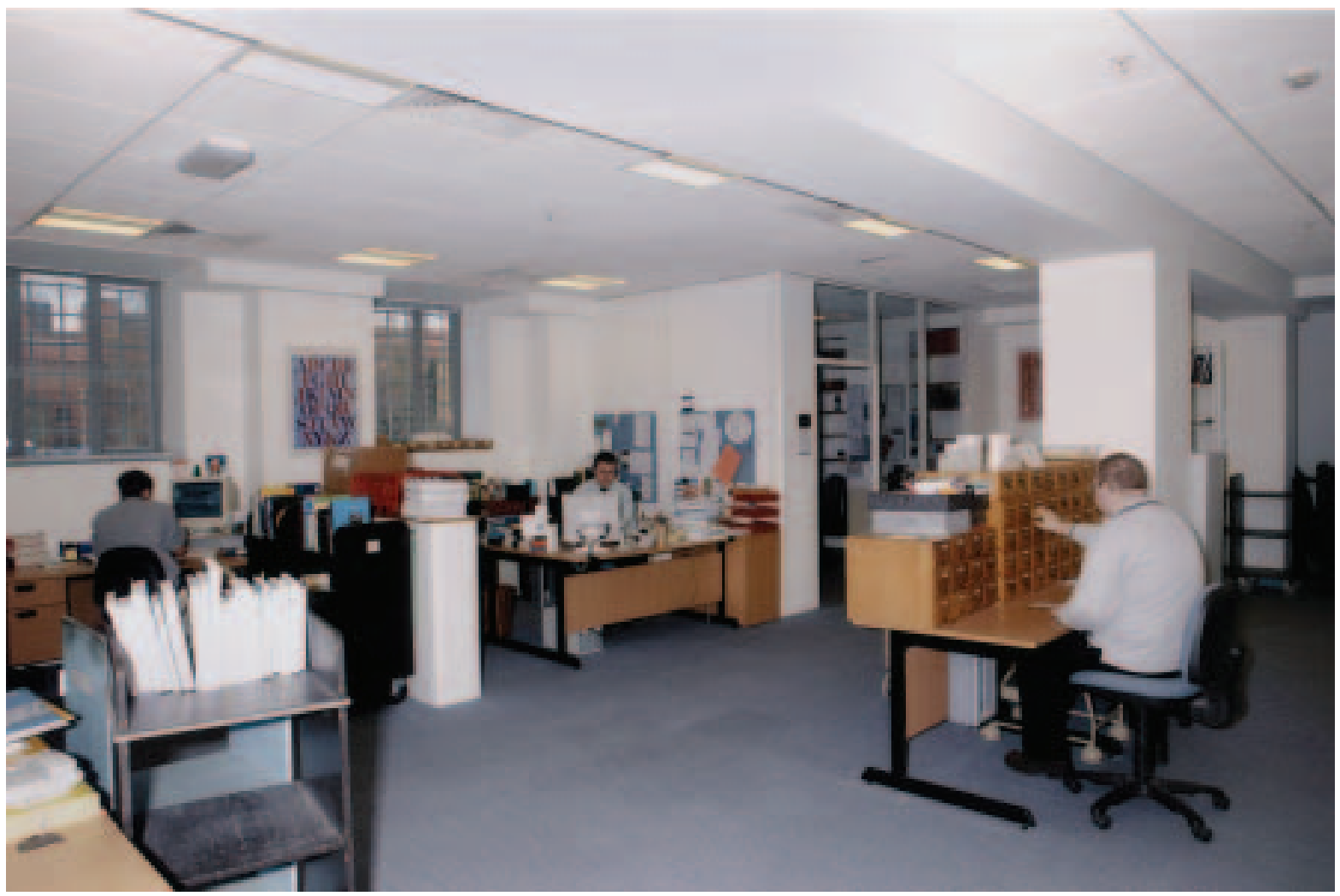

Cambridge University Library:

stage III, phase 4, ground floor (Legal Deposit Office) 


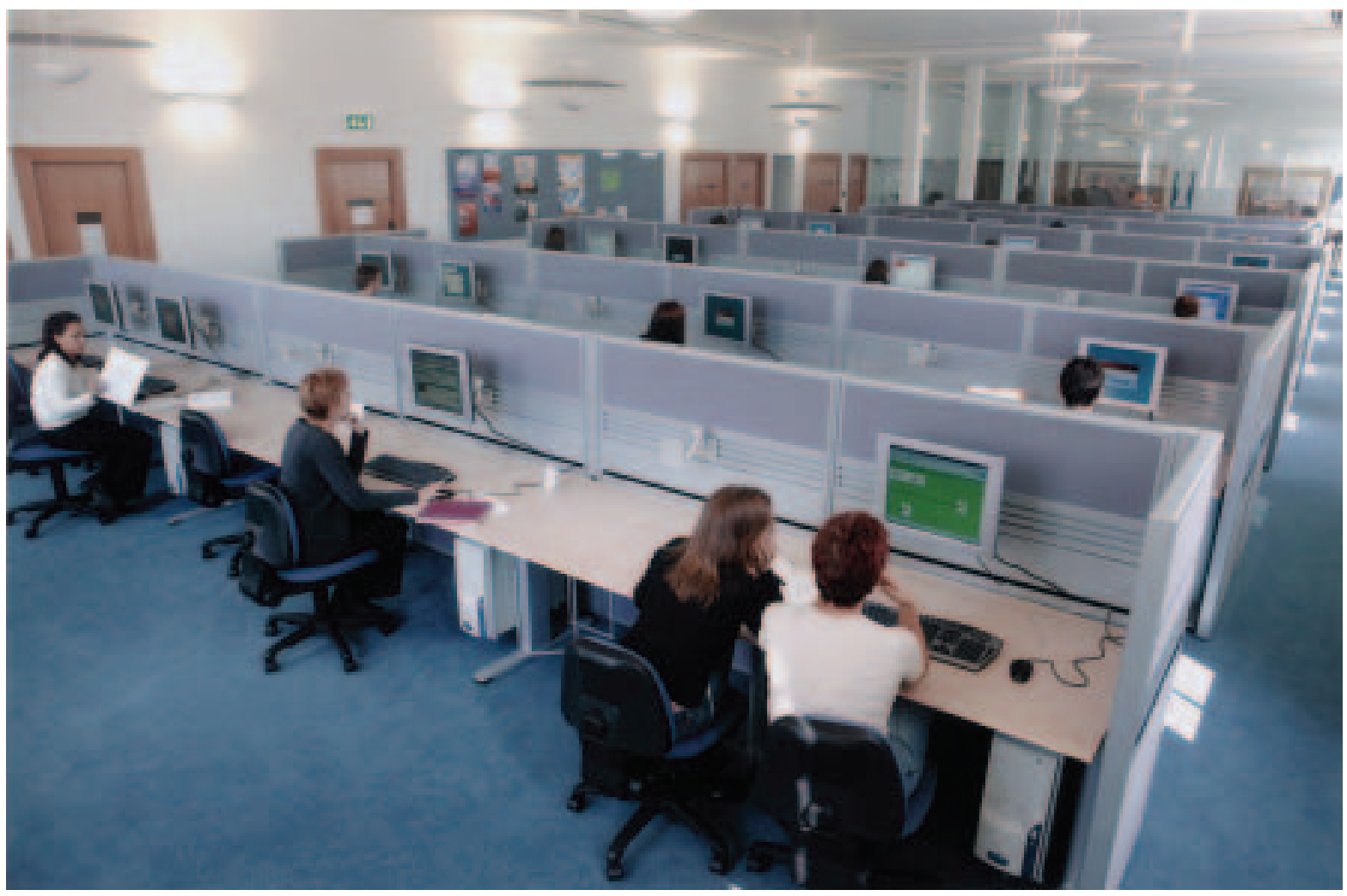

Cambridge University Library:

stage III, phase 4, first floor (Digital Resources Area) 
Cambridge University Library: stage III, phase 4, third floor (Official

Publications Reading Room) Photograph: Nick Carter

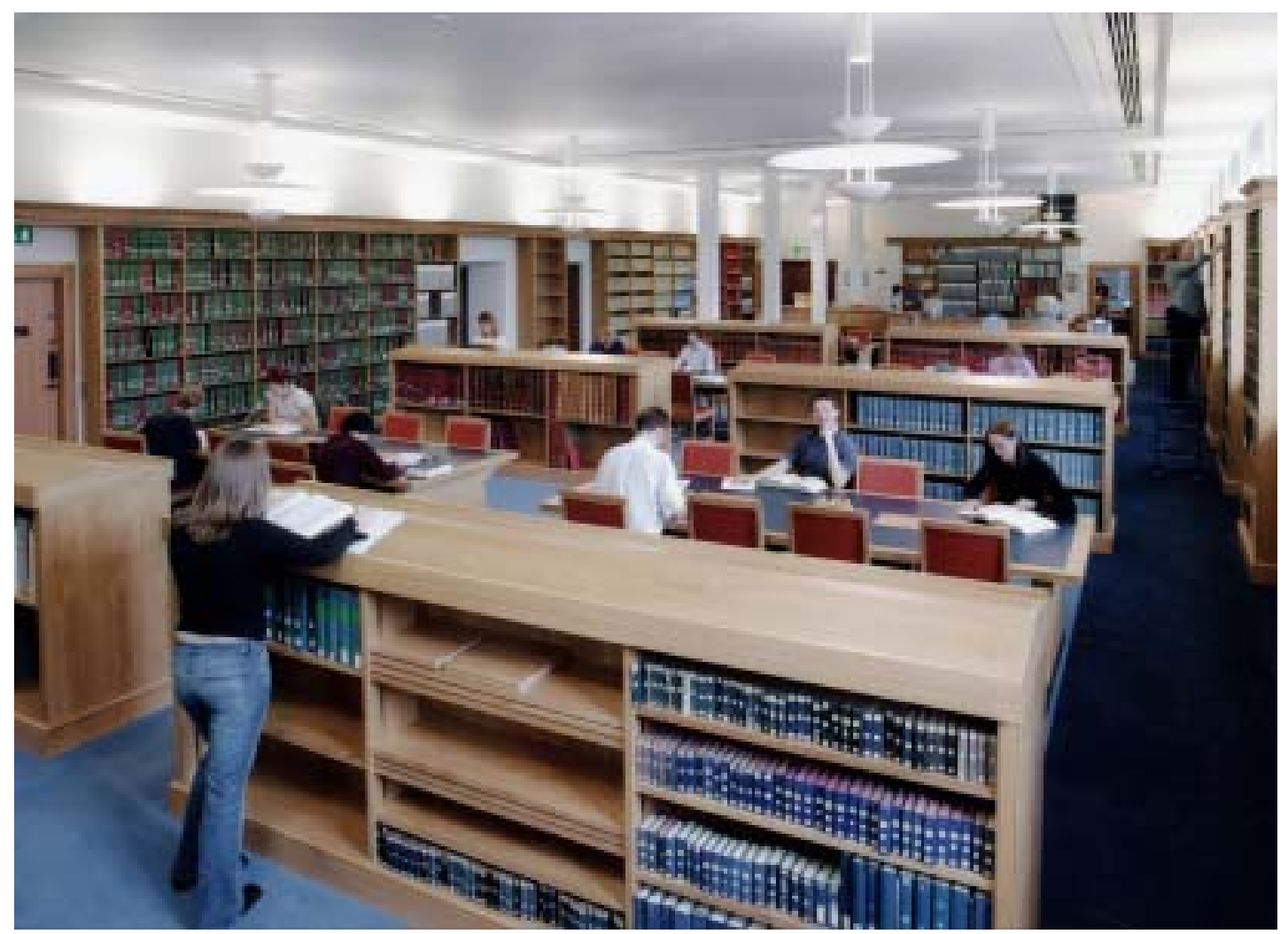


Cambridge University Library: stage III, phase 5 (mobile bookstacks)

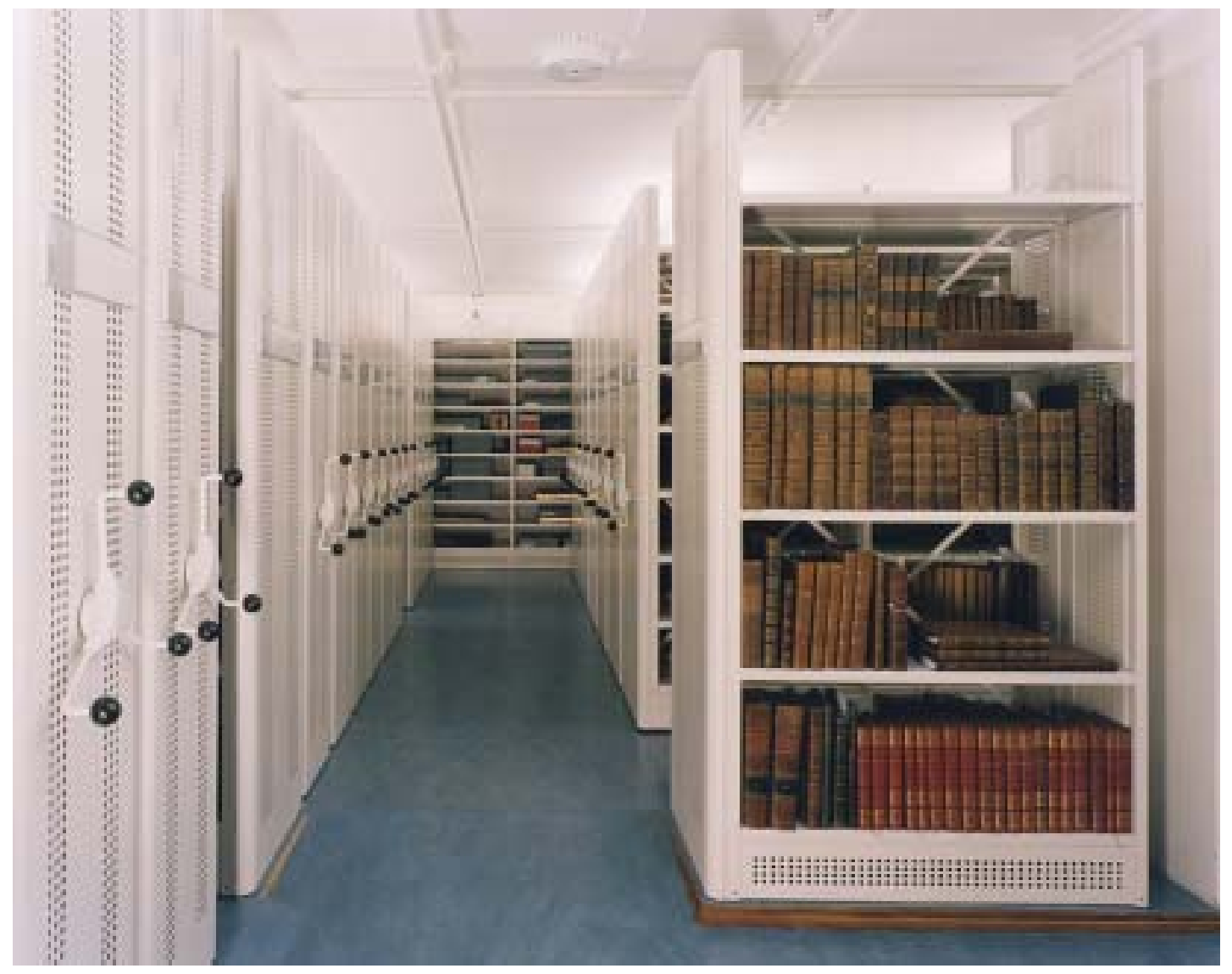



Cambridge University Library -

Betty and Gordon Moore Library

for the Physical Sciences, Mathematics and Technology 


\section{A GENERAL INFORMATION ABOUT THE LIBRARY}

a) Name and address

1. Academic/Research. A branch of Cambridge University Library

2. Cambridge University Library, Betty and Gordon Moore Library for the Physical Sciences, Mathematics and Technology

3. Wilberforce Road, Cambridge CB3 OWD, United Kingdom

4. Phone: 01223-765670

Fax: $\quad 01223-765678$

E-mail: moore-library@lib.cam.ac.uk

5. Peter K. Fox

6. Michael L Wilson

b) Population served

7. 2,200

8. 17,478

9. 2,560

10. 4,761

c) Conditions of the library (before the new project)

11. $317 \mathrm{sq} \mathrm{m}$

12. 114

13. $1526 \mathrm{~m}$

14. $1526 \mathrm{~m}$

16. 2

17. 42.5 hours per week; 252 days per year

\section{B THE NEW BUILDING: AIMS AND FEATURES}

\section{a) Architect(s)}

18. Edward Cullinan Architects. http://www.edwardcullinanarchitects.com/

19. Johnny Winter RIBA

20. New building: yes

b) Aims of the new building

21. The establishment of a new branch library of the main University Library 
covering the Physical Sciences and Technology, uniting subject collections previously held on four sites and absorbing two departmental collections. To provide additional reader/study space, secure 24 hour access to the collections, and improved IT workstation provision on a site adjacent to major University expansion.

\section{c) Special Features}

22. The site is suburban, with residential housing to three sides, located to the west of the city centre. The Library building was developed as part of the Architect's overall plan for the University's Centre for Mathematical Sciences (http://www.cms.cam.ac.uk/) which brought together the two mathematics departments of the University and the Isaac Newton Institute, the national research centre for the mathematical sciences and their applications. The site is close to the West Cambridge major building development, including accommodation for the Computing Laboratory, and the existing Cavendish Laboratories of the University Physics department and outlying residential Colleges. The site is linked to the city by bicycle routes and regular public transport.

23. The Library is a free standing circular construction. Brick clad reinforced concrete frame to first floor cill level, with cladding above and zinc sheet roof. Each floor is a flat concrete slab. The building has a circular plan for the three floors above ground level. One floor below ground level extends into a rectangular plan beneath the footprint of the building above with a trapezoid extension providing natural light to enter the lower ground floor. Natural ventilation and cooling as part of an integrated building management scheme is provided in the upper two floors. Access via central lift and two load bearing stairwells.

Disabled access provided throughout.

\section{TECHNICAL INFORMATION ABOUT THE NEW BUILDING}

\section{a) Floor area (in sq metres) for questions 24 to 33}

24. $3,339 \mathrm{sq} \mathrm{m}$

25. $2,787 \mathrm{sq} \mathrm{m}$

29. 2 small seminar rooms, $30 \mathrm{sq} \mathrm{m}$

33. $120 \mathrm{sq} \mathrm{m}$ 
35. $402 \mathrm{sq} \mathrm{m}$

36. Four floors with reader access to all shelves.

37. 324

39. 41

40. 12

41. 271

b) Total potential capacity of shelving (linear metres or volumes)

42. $7,000 \mathrm{~m}$

43. $7,000 \mathrm{~m}$

45. $2,730 \mathrm{~m}$

47. Periodical display $870 \mathrm{~m}$

48. 8.5

\section{c) Mechanical features}

49. Natural ventilation and cooling managed via integrated building management system for upper two floors. Cooling in ground and lower ground floors by chilled beams.

50. Low temperature hot water radiators fed from natural gas boiler.

51. Fluorescent luminaries plus task lighting. Extensive use of motion detector activated lighting in stack and circulation areas. Light levels of 400 lux average in staff areas and 300 lux in public areas.

52. Acoustic separation of ground floor services from upper two floors and lower ground floor. Acoustic dampers fitted to air transfer shafts used in natural ventilation of upper floors.

53. 13 person $1000 \mathrm{~kg}$ side hydraulic lift.

55. 3M book detection system.

56. Automatic blinds fitted as part of integrated building management system.

57. CAT 5E UTP cable. Capacity for IT and power connections to all desks.

58. Shelving. Fixed shelving: BCl Opal (http://www.bci.dk/) with etched glass end panels. Public accessible compact shelving: customised Eccospace units by Demco Library Interiors.

\section{SCHEDULE OF THE BUILDING PROCESS}

59. February 1996

60. Building part of larger development for which Architect already selected. 
61. From 1997 to January 1999

62. February 2000

63. 17 months

64. July/August 2001

65. 1 October 2001

\section{E COSTS}

66. Not applicable to the Library. Site acquired by University from College for entire site development

67. $f 6,378,000$

68. $f 185,000$

69. $f 1,275,000$

70. $f 7,838,000$

\section{F PUBLICATIONS:}

Hale, Jonathan: Ends, Middles, Beginnings : Edward Cullinan architects, Black Dog Publishing 2005. 


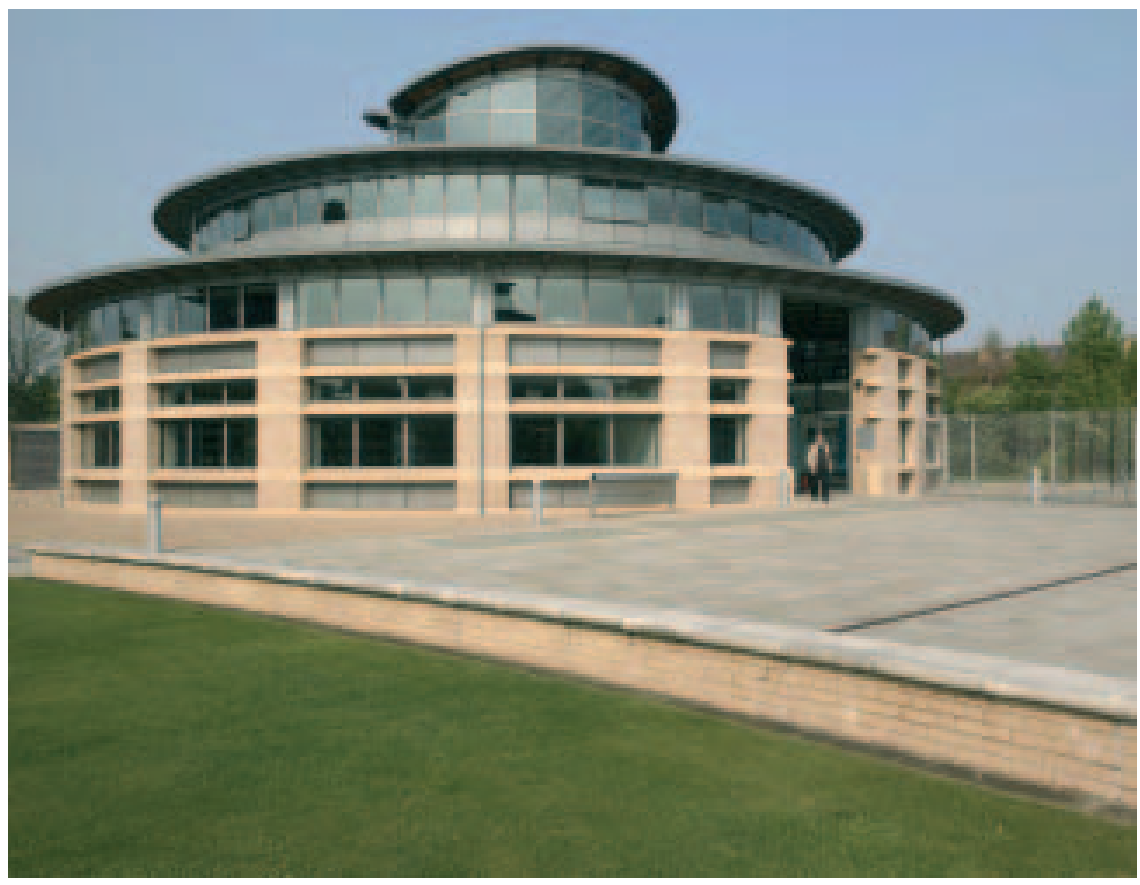

Cambridge University Library Betty and Gordon Moore Library for the Physical Sciences, Mathematics and Technology

Exterior

(c) University of Cambridge 


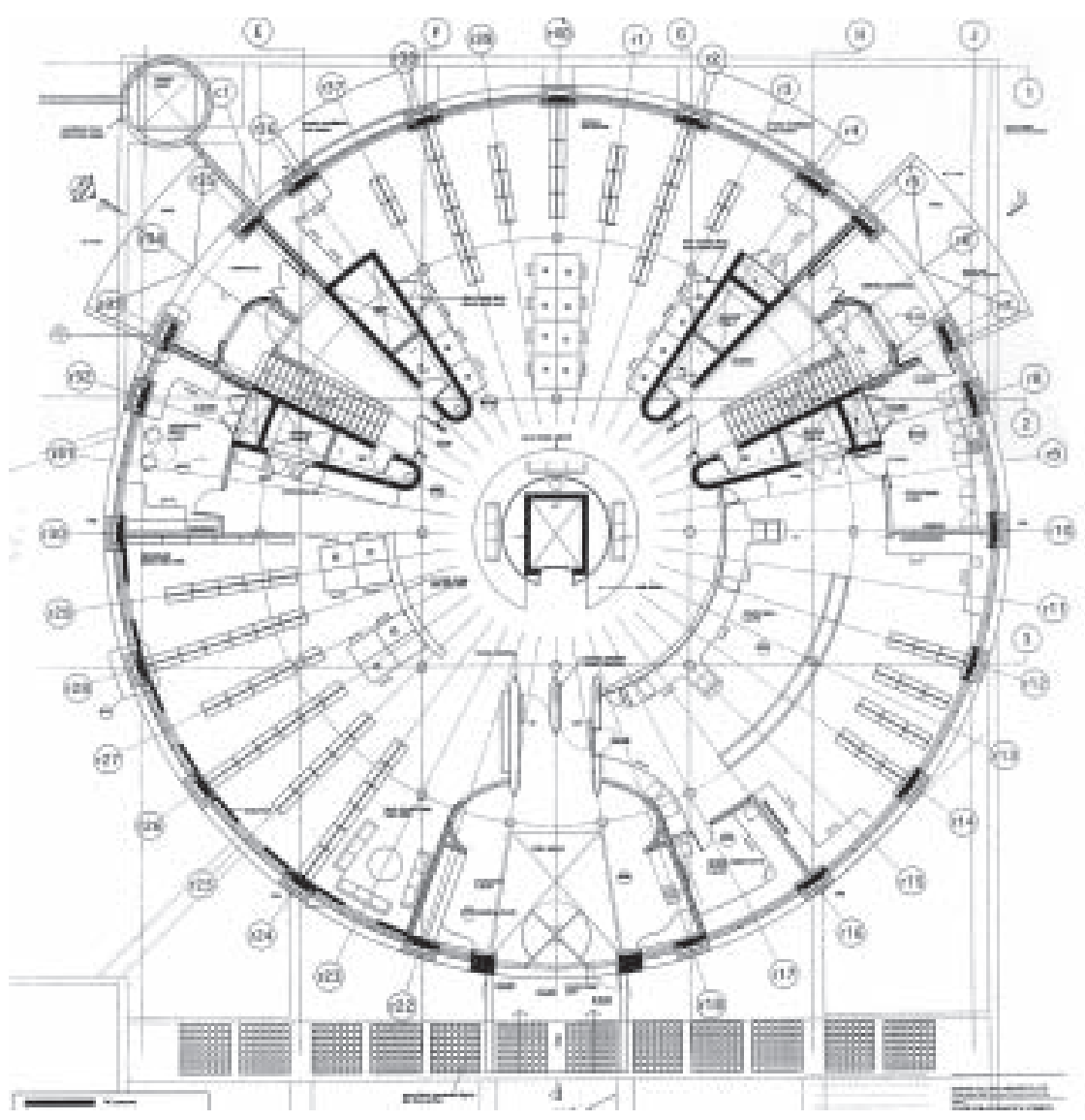

Cambridge University Library -

Betty and Gordon Moore Library for the Physical Sciences,

Mathematics and Technology

Ground floor plan

(C) University of Cambridge 


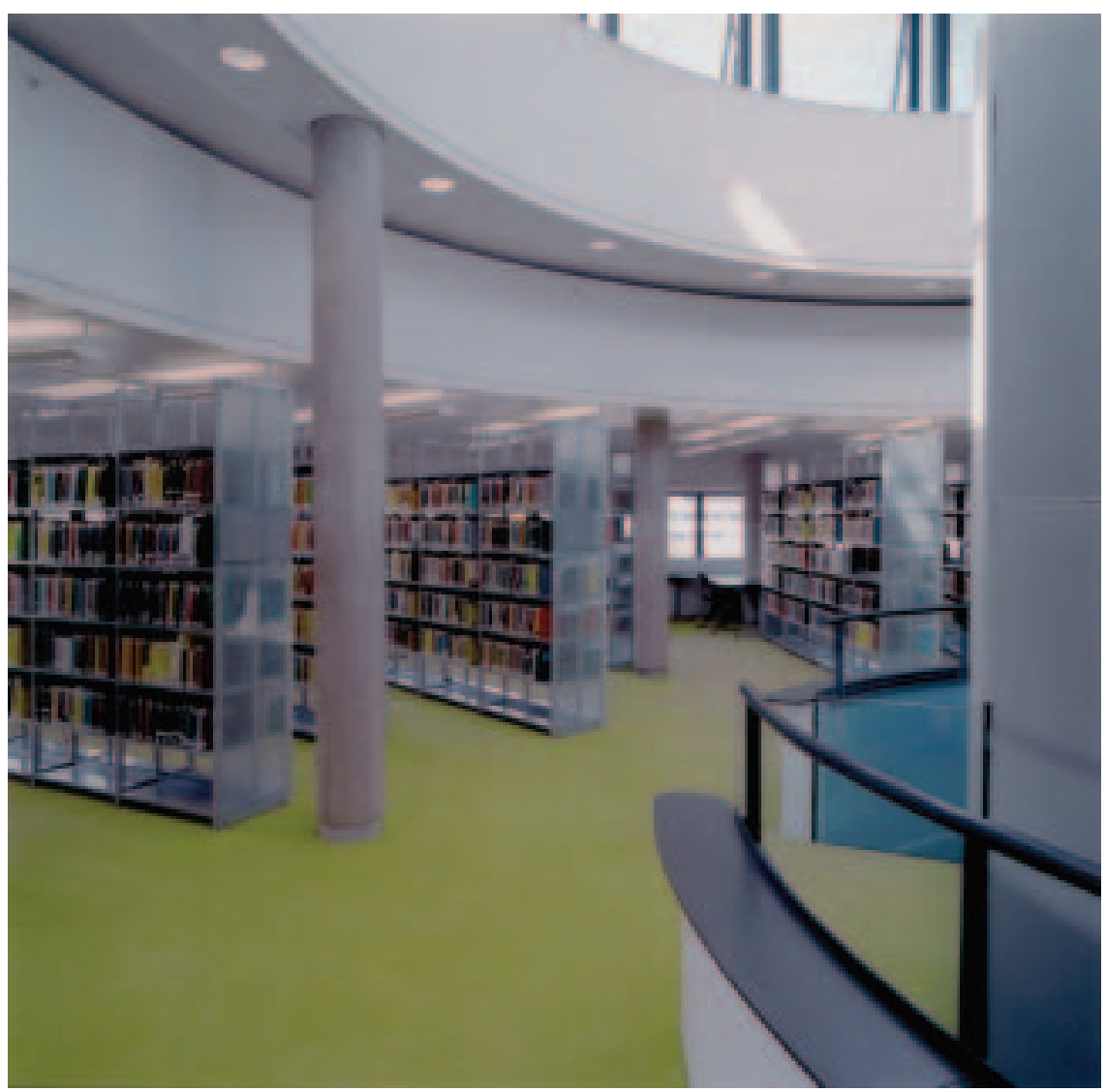

Cambridge University Library Betty and Gordon Moore Library for the Physical Sciences, Mathematics and Technology Interior, Floor 2

(C) University of Cambridge 


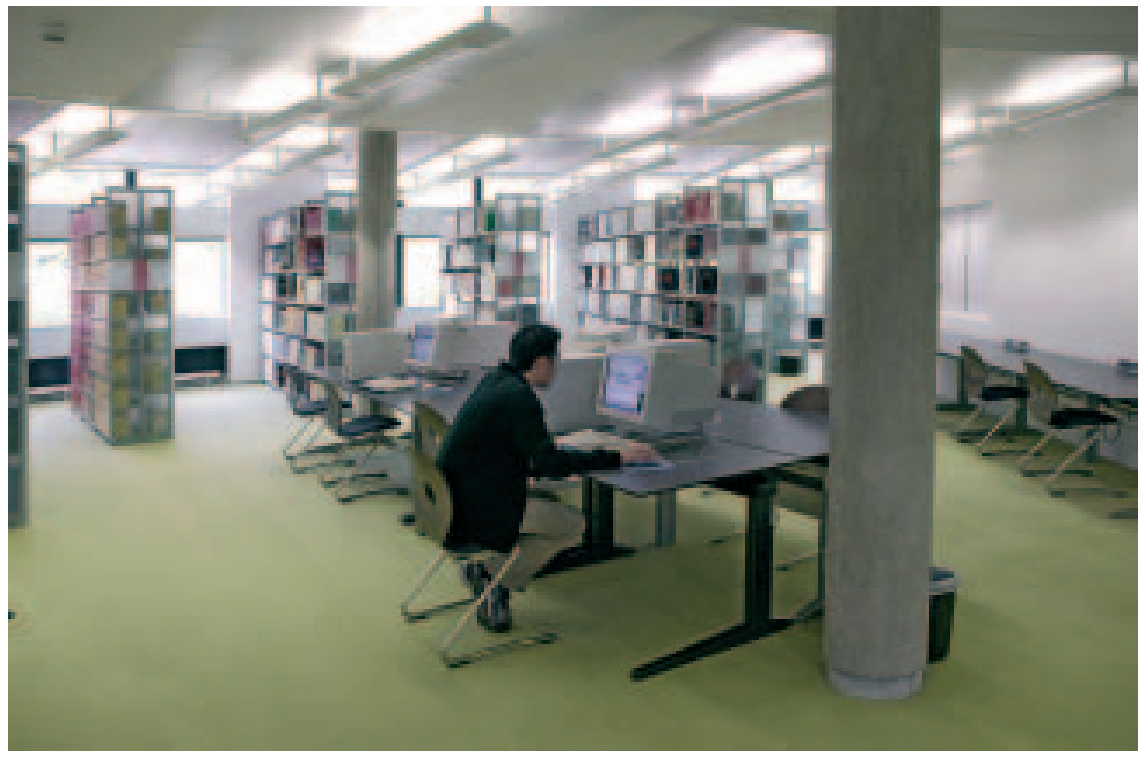

Cambridge University Library -

Betty and Gordon Moore Library for the Physical Sciences, Mathematics and Technology

(c) University of Cambridge 


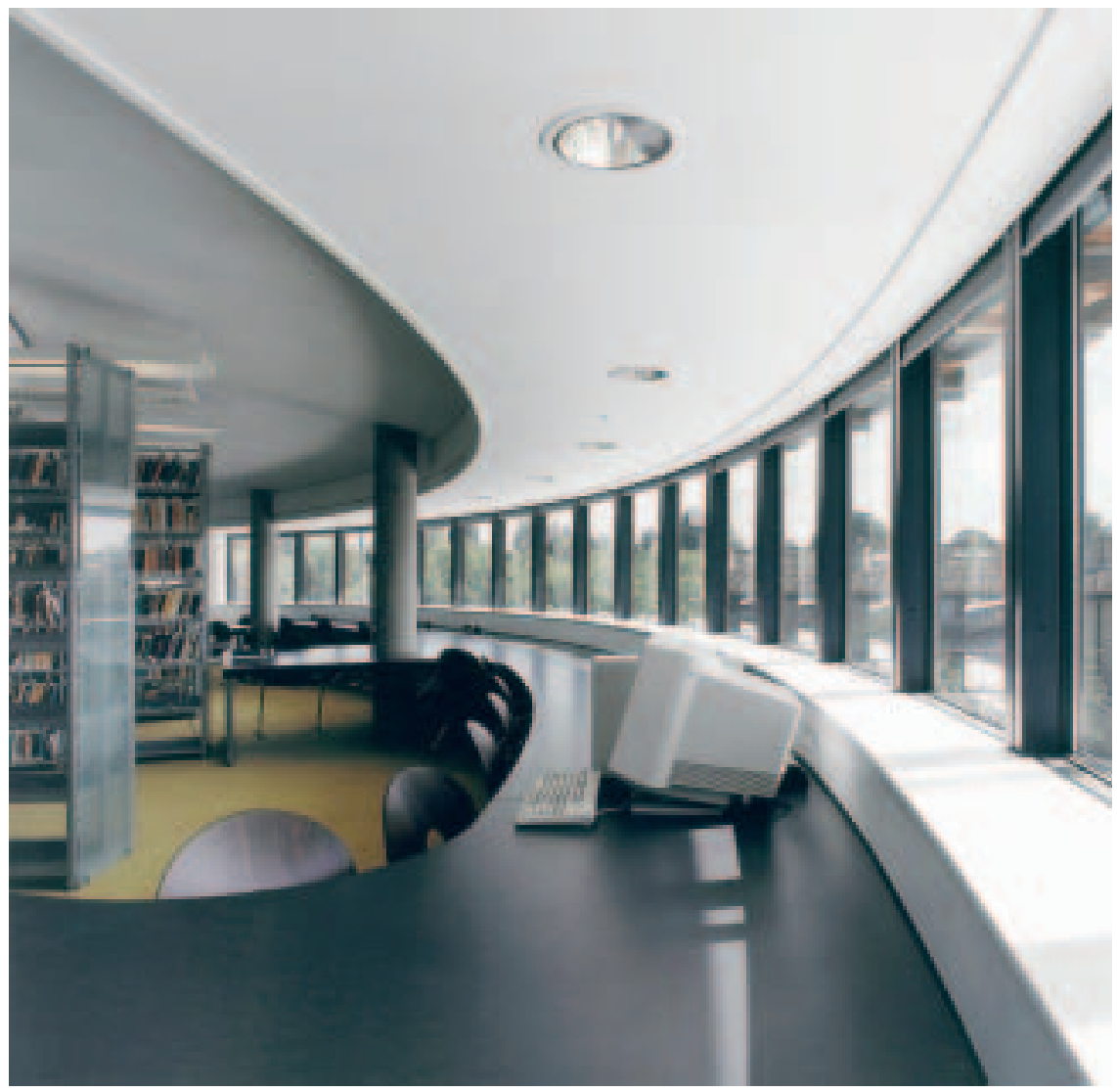

Cambridge University Library -

Betty and Gordon Moore Library for the Physical Sciences,

Mathematics and Technology

Interior, Floor 1

(c) University of Cambridge 
Cambridge University Library Squire Law Library
at the Faculty of Law 


\section{A GENERAL INFORMATION ABOUT THE LIBRARY}

\section{a) Name and address}

1. Academic law library for both undergraduate students and advanced researchers

2. Cambridge University Library, Squire Law Library at the Faculty of Law

3. University of Cambridge

10 West Road

Cambridge, Cambridgeshire, CB3 9DZ

United Kingdom

4. Phone: 01223330077

Fax: 01223330057

E-mail: dfw1003@cam.ac.uk

Website: http://squire.law.cam.ac.uk

5. Peter K. Fox (University Librarian); David F. Wills (Squire Law Librarian)

6. David F. Wills

b) Population served

7. 1,000 (in Law)

8. 17,478 (in the University)

9. 2,560 (in the University)

10. 4,761 (in the University); 150 (in Law) approximately

c) Conditions of the library (before the new project)

11. $9,000 \mathrm{sq} \mathrm{m}$ gross for the Law Building as a whole; $4,000 \mathrm{sq} \mathrm{m}$ gross for the Squire Law Library within the building

12. 430

13. 12,000 metres

14. 9,200 metres

15. 2,800 metres

16. 11 Library staff (excluding I.T. staff)

17. Opening hours vary according to the time of year and whether in term or in vacation. On average 68 hours per week in term; 54 hours per week in vacation. The Library is open on c. 304 days per year 


\section{B THE NEW BUILDING: AIMS AND FEATURES}

\section{a) Architect(s)}

18. Foster and Partners (http://www.fosterandpartners.com/)

19. Spencer de Grey

20. New building: yes

\section{b) Aims of the new building}

21. The Faculty of Law building was designed to bring together the Faculty of Law and the Squire Law Library under one roof. The Squire had outgrown its previous accommodation, the Cockerell Building (which is now the Gonville and Caius College Library).

The design, which is on six levels, incorporates the library on the top three floors (as well as storage rooms in the lower levels of the building). In the lower ground and basement levels are three large auditoriums with other teaching rooms to be found at ground level. Throughout the building there are offices for teaching members, as well as for administrative and library staff and there are various common room facilities for all users of the building. The Building allows space for the extensive collections of the Squire Law Library and provides seating for 430 readers with areas allocated specially for computer workstations. The glass-curved façade on the north side offers excellent natural light for the reading areas of the library and the feeling of spaciousness helps to create a modern, state-of-the-art study and research facility.

\section{c) Special Features}

22. Location of the library: Sidgwick Site Within the University of Cambridge

Within reach of direct rail services to/from London, the M11 motorway, and local bus and taxi services in Cambridge.

The Building is situated to the west of the centre of Cambridge on the University's Sidgwick Site between Sidgwick Avenue and West Road. It is sited adjacent to Casson and Conder's original Raised Faculty Building and opposite Stirling's History Faculty building. Other Faculties together with their libraries, many of which are in new buildings of their own, are also located around the site including the Institute of Criminology, the Faculty of Divinity and the Faculty of English. The University Library, of which the 
Squire is a dependent library, is within five minutes walk on the other side of West Road heading north from the Sidgwick Site.

23. The in-situ concrete structure is raked at an angle to reflect the terracing. The curved glazing, with its repetitive triangular grid, is supported by a triangulated steel vieredeel structure spanning nearly 40 metres as an arc. Most of the book stacks are located in the centre of the plan with staff offices on the south elevation. Externally, the curved north façade's structural silicon glazing develops into a stainless steel roof above. The west façade and part of the east façade are also glazed and carefully designed to address heat gain and glare. The west wall forms a sinusoidal curve in plan, resolving the 45 degree cut of the cylindrical form with the triangular geometry of the north elevation. The vertical south façade is part clad in reconstituted Portland stone, reflecting the Raised Faculty Building opposite, and part translucent glazing with clear horizontal vision strips. These are shaded from sun and incorporate opening windows for natural ventilation. Internally, the structure provides considerable flexibility, with generous column free spaces. Particular attention was given to the finish of the visible in-situ columns and pre-cast beams to create a high quality finish, achieved by sand blasting the concrete to expose its Scottish granite aggregate.

The building is highly energy efficient, taking full advantage of the thermal mass of the exposed internal concrete structure. Externally, various devices are used to shade the enclosing envelope. This, together with the high insulation values achieved, allows the building to be naturally and mechanically ventilated throughout, the auditoria being the only spaces to be cooled. There is a lighting management system to reduce energy consumption and heat recovery coils, linked to the air extract, reclaim heat from extracted air.

The building meets modern fire and safety regulations and is designed to enable disabled users to have easy access to all levels including the lecture theatres and the library.

\section{TECHNICAL INFORMATION ABOUT THE NEW BUILDING}

\section{a) Floor area (in sq metres) for questions 24 to 33}

24. $4,000 \mathrm{sq} m$ for the library floors

25. As above 
27. One computer teaching room with 24 computers, other areas designated for computers on floors 2 and 3 of the library; total $320.43 \mathrm{sq} \mathrm{m}$

28. One Legal History Room housing rare and valuable legal antiquarian publications on floor 1 of the library; 128 sq m (approx)

29-32 inclusive below relate to Faculty-administered areas of the building that are not directly part of the library:

29. Various rooms around the building not directly part of the Library; total: $300 \mathrm{sq} \mathrm{m}$

30. The Atrium (dimensions $\mathrm{n} / \mathrm{k}$ ) and Ground Floor Reception Foyer (303.5 sq m)

31. Three large lecture theatres total: $592.19 \mathrm{sq} \mathrm{m}$

32. Servery and associated Junior Common Room space with tables and seating: totals $162.43 \mathrm{sq} \mathrm{m}$

33. For Library staff and library administration: total: $140.94 \mathrm{sq} m$

34. 2,793 metres of shelving

36. 6 floors (The Library is located on 3 floors)

37. 430

39. 75

41. 355

\section{b) Total potential capacity of shelving (linear metres or volumes)}

42. 180,000 volumes

43. 140,000 volumes (approx)

44. 40,000 (approx)

45. As 44 .

48. 11

\section{c) Mechanical features}

49. The building is mechanically ventilated to achieve ten air changes per hour, with additional comfort cooling provided for the main auditoria using a chilled water system and natural ventilation for the south-facing administration and staff accommodation. The supply and extract systems operate on $100 \%$ fresh air, coupled with run-around coils to reclaim heat from extracted air for energy conservation.

Air is generally supplied into the main spaces through a combination of slot and cast-in swirl diffusers. The atrium is supplied by long throw jet diffusers at lower ground and third floor level. The temperature is regulated using balancing sensors at the east and west ends of the building and inverter 
drives are used to vary the fan volumes as required.

50. The building is heated using gas fired boilers and a system of primary and secondary circuits feeding the air handling units, together with perimeter heating elements in the north and south edge of each floor slab and at the base of the main external cladding.

51. All lighting in the building is controlled from the main reception desk at the ground floor and first floor levels. An energy-saving lighting management system in the main library areas (e.g. over the book-stacks) ensures that lighting levels are kept at an acceptable minimum in unoccupied areas. Light levels increase by $50 \%$ to a level sufficient for reading when an area is occupied. This system is activated and controlled using a system of passive infra red detectors mounted in the body of the luminaries.

52. The raking auditoria provide natural acoustics with additional sound systems to support both static and roving microphones.

The reading spaces within the library on floors 1, 2 and 3 are separated from the social spaces of the atrium by a vertical glass screen ensuring that these study areas are quiet working spaces.

53. 2 Lifts (passenger and goods)

55. 3M Book detection system

56. Swipe card security access system for authorised personnel

57. Cabling to all reader desks within the library and offices throughout the building

\section{SCHEDULE OF THE BUILDING PROCESS}

59. To provide a building that accommodated the Faculty of Law, the Squire Law Library, auditoria, seminar rooms, senior and junior common rooms and office spaces for the Faculty's administration, for Library staff and for teaching members.

60. 1990: A limited architectural competition was held by the University which was won by Foster and Partners

62. June 1993: Construction began

63. September 1995: Construction completed

64. Furnishings and the library collections were moved into the building during the summer of 1995

65. The building was open to users in time for the beginning of the academic year 1995/1996 (i.e. from October 1995) 
The Building was officially opened on 8 March 1996 by H.M. The Queen with the Chancellor of the University, H.R.H. The Duke of Edinburgh, in attendance.

\section{E COSTS}

66. Site acquired by the University from Gonville and Caius College

\section{F PUBLICATIONS:}

- Best, Alastair: Legal precedent, in: Architectural Review, 199 (1996), no. 1189, p. 34-42. ISSN 0003-861X.

- Foster, Norman: Works, Vol. 1-4, ed. David Jenkins, Munich/London: Prestel 2002-2005.

- Jodidio, Philip: Sir Norman Foster, Köln/London: Taschen 1997.

- Library builders, London: Academy Editions 1997.

- Sir Norman Foster \& Partners, in: Architects' Journal, 202 (1995), no. 4, p. 24-29. ISSN 0003-8466. (Illustrates 15 recent and current projects and completed buildings worldwide.) 


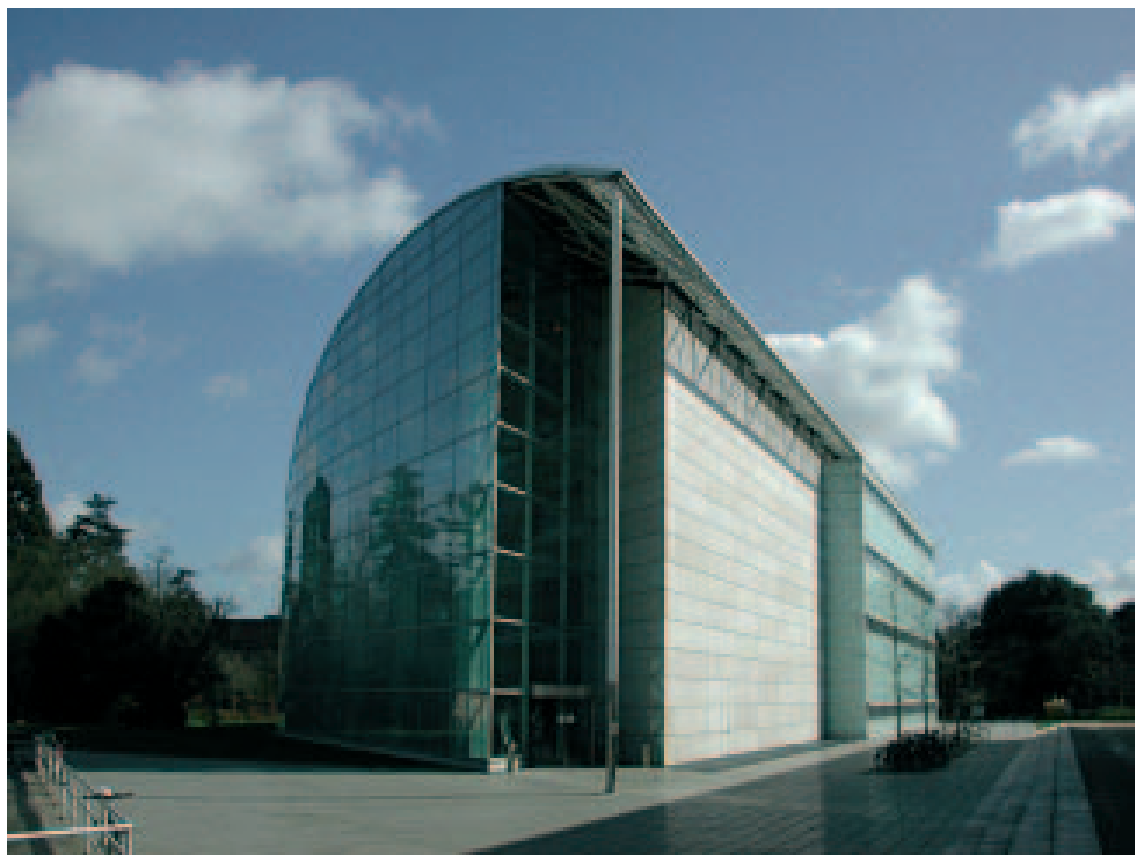

Cambridge University Library - Squire Law Library

(c) Faculty of Law, Cambridge University

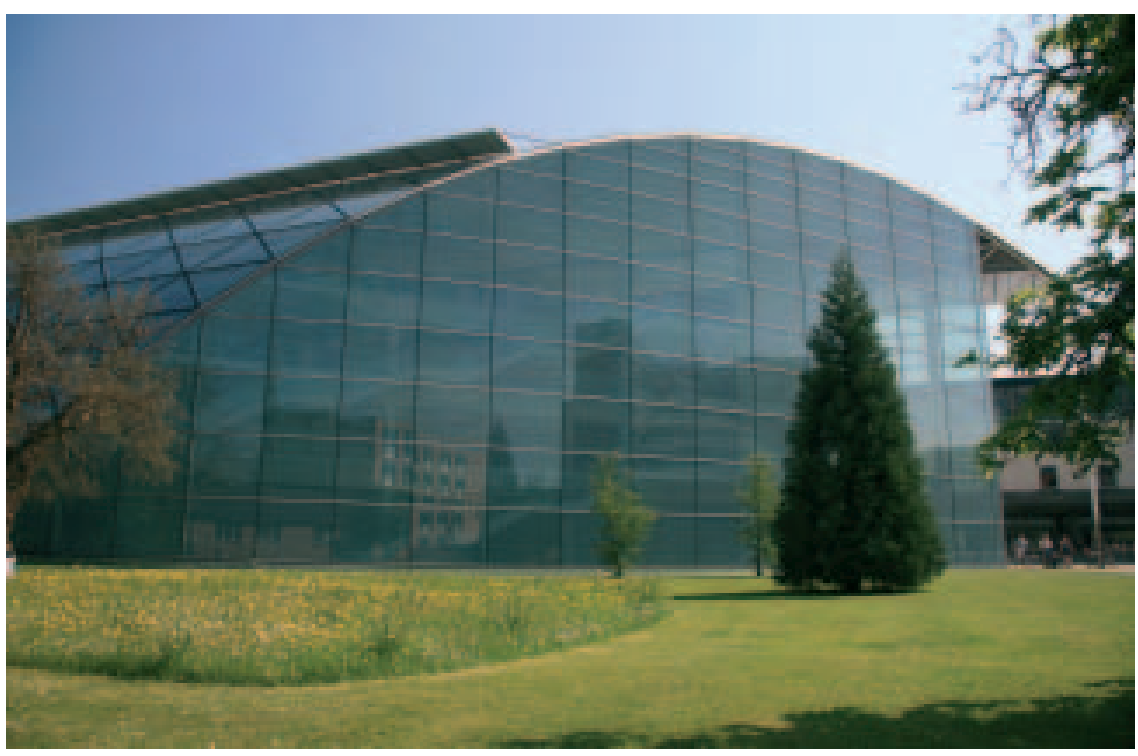



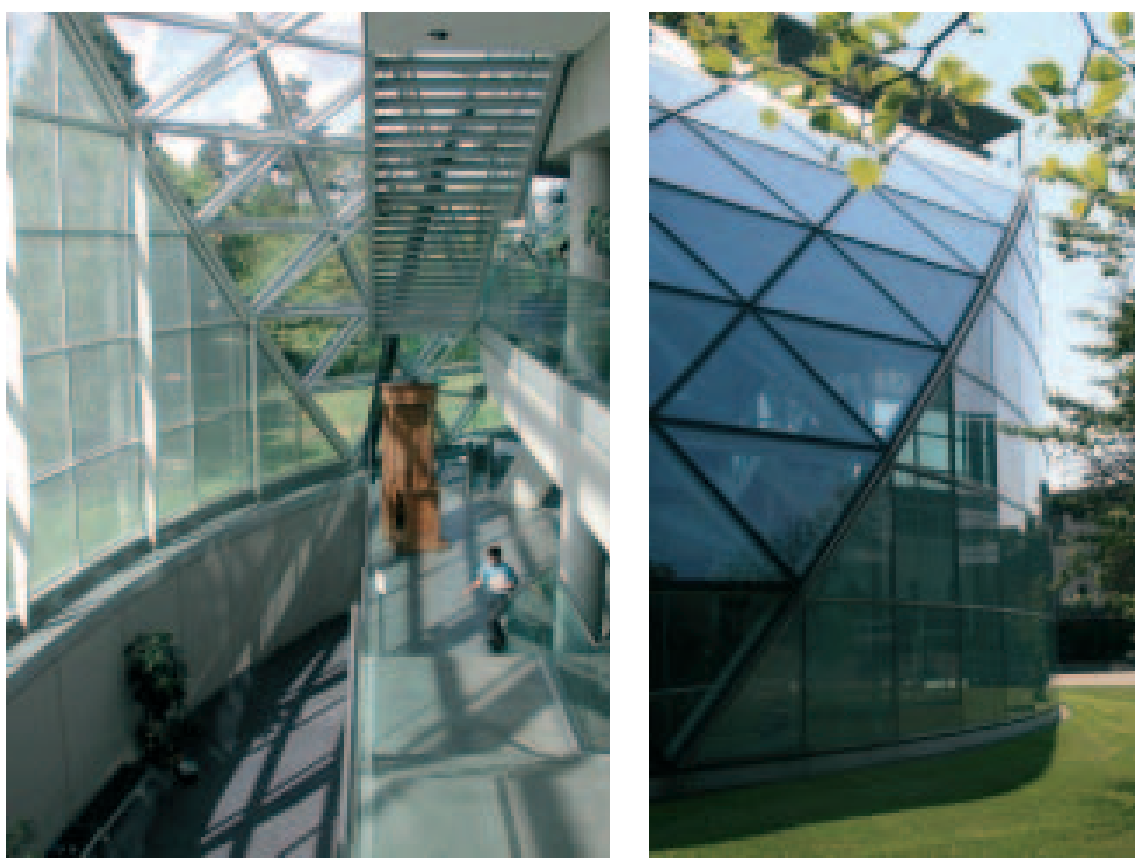


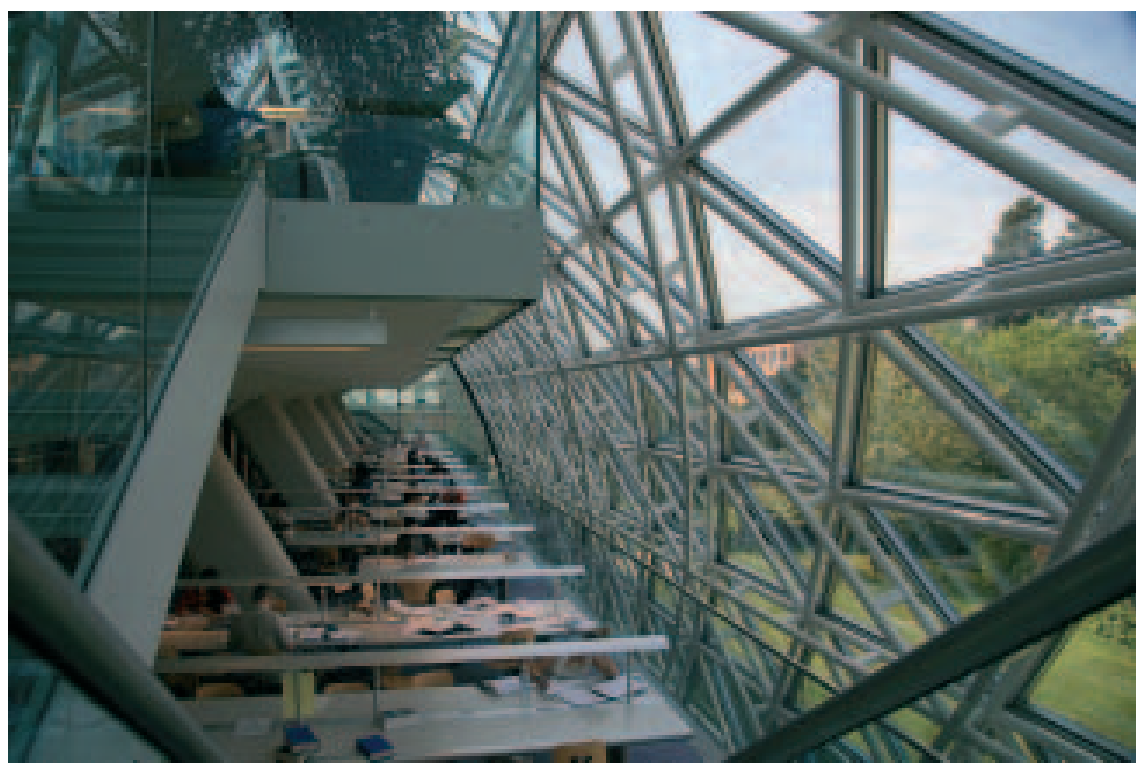

Cambridge University Library - Squire Law Library 


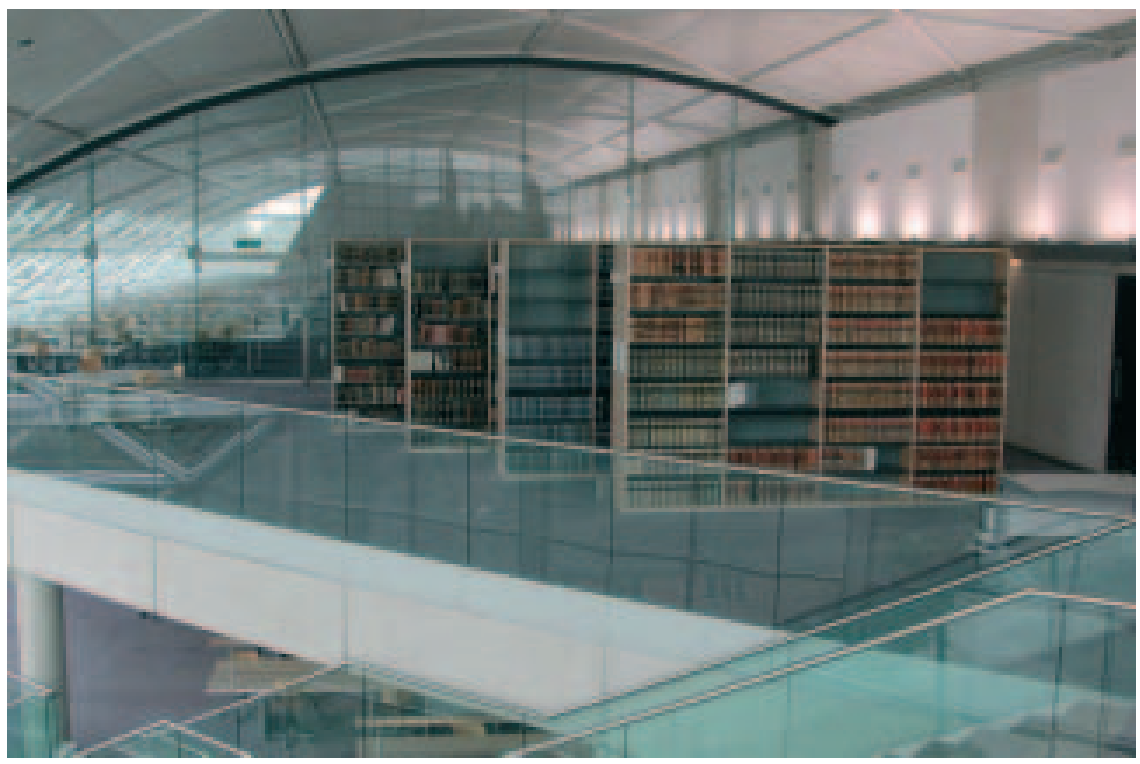

Cambridge University Library - Squire Law Library

(C) Faculty of Law, Cambridge University

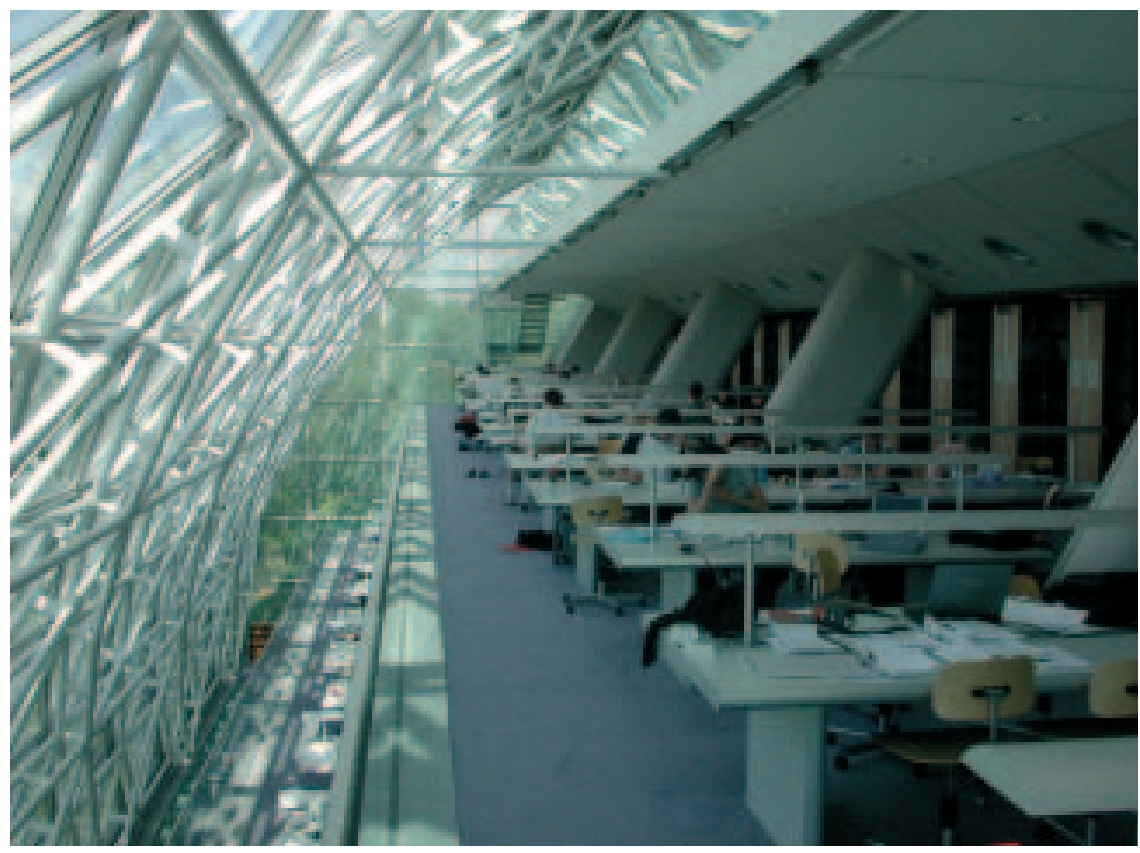



Department of Chemistry Library 


\section{A GENERAL INFORMATION ABOUT THE LIBRARY}

The Cambridge University Department of Chemistry Library stocks books and periodicals in the fields of inorganic, organic, physical and theoretical chemistry, which, at the research level overlap with physics, materials science, biochemistry, biology and medicine.

It is a highly-valued facility for academic and assistant staff of the Dept of Chemistry, post-doctorate researchers, post-graduates and undergraduates studying chemistry and other related disciplines across the university.

The new Chemistry Library, forming part of the new Unilever Centre for Molecular Informatics, was built between 1999 and 2000. The building is separately constructed but attached by bridge walkways to the main building of the Department of Chemistry. The aim was to provide an open-plan space for private study with book storage and on-line computer facilities suited to an increasingly electronic age. The library supports the research and teaching needs of the Department of Chemistry in terms of stock and electronic access and provides a quiet and calm environment for scholarly work.

First impressions on entering the library are of space and light. The formal study places and computer workstations are complemented by comfortable armchairs in the periodical browsing area.

a) Name and address

1. Academic departmental library

2. Cambridge University Department of Chemistry Library

3. Lensfield Road

Cambridge, CB2 1EW

4. Phone: 01223336329

Fax: 01223336362

E-mail: library@ch.cam.ac.uk

5. Prof J.K.M. Sanders

6. Mrs J. Battison

b) Population served

7. 390 registered for borrowing

8. 1500 cards programmed for library access

10. $600+$ 


\section{c) Conditions of the library (before the new project)}

11. $466 \mathrm{sq} \mathrm{m}$

12. 100

16. 1

17. Open to members of Cambridge University only and visitors by special arrangement.

Staff and research students Mon-Sat 08:45-22:00 Sun 8:45-17:30

Undergraduate students and visitors Mon-Fri: 08.45-19.00 Sat: 08.4513.00 Sun: closed

\section{B THE NEW BUILDING: AIMS AND FEATURES}

The library aims to provide a quiet environment for scholarly work with access to on-line information systems and a book and journal repository.

\section{a) Architect(s)}

18. Cornelia Zibrandtsen Architects, Denmark

A local company, CMC Architects, was commissioned as Executive Architects.

19. Cornelia Zibrandtsen together with Professor Erik Christian Sorensen

20. New building: yes

Extension: yes

\section{b) Aims of the new building}

21. The library, serving the entire Department of Chemistry, is an integral part of a new building aiming to provide the best facilities for teaching and research in chemical sciences.

It provides more reader seats at study tables and access to electronic facilities in one location. It includes a comfortable seating area for browsing.

It provides a suite of networked computers and wireless facilities.

It allows access to students and staff via electronically-validated university cards 364 days a year from 06.00-23.59.

\section{c) Special Features}

The light, spacious library with on-line information systems occupies the whole of the first floor of the Unilever building. This huge space with a height of 5 metres is constructed with 12 steel columns and an enormous steel tree supporting the second floor. The tree is placed under a glass pyramid from which daylight is reflected through a light-well. The materials 
for the library were carefully chosen for their light reflective and acoustic qualities. The floor is tongued and grooved maple, the walls whitewashed brick and the ceiling is constructed with red lacquered panels.

The steel tree symbolises Yggdrasil, the World Ash tree in Scandinavian mythology which has its roots in the underworld and reaches up towards the light with its branches in the heavens. This is considered a powerful symbol of the role of molecular chemistry.

A specially-commissioned bronze statue of Minerva by Danish artist Jette Vohlert overlooks the reading room.

22. On the Department of Chemistry site, on the city ring road, 10 minutes walk from Cambridge centre. Close to public transport.

23. The new building, of which the library is a part, forms nearly a square. It is set on a slight angle to the Department of Chemistry and adjacent road. The south elevation is broken to fit the street lines and the small scale of the historic houses in the vicinity.

The library's high windows supplement the natural light entering from the roof through the light-well. The steel columns surrounding the steel tree of knowledge make a strong visual impact.

The materials for the library were selected for their light reflective and acoustic sound-absorbing qualities.

There is disabled access.

\section{TECHNICAL INFORMATION ABOUT THE NEW BUILDING}

\section{a) Floor area (in sq metres) for questions 24 to 33}

24. $696 \mathrm{sq} \mathrm{m}$

25. $594 \mathrm{sq} \mathrm{m}$

27. No special room

(Computers are in the main open-plan reading room)

29. Within the new building but not part of library

30. Space within the main reading room

31. Within the new building but not part of library

32. Cyber café on floor above library, separately managed and not part of library

33. Office: $20 \mathrm{sq} \mathrm{m}$

34. Basement stack: $75 \mathrm{sq} \mathrm{m}$

35. Print room: $7 \mathrm{sq} \mathrm{m}$ 
36. 2 levels - first floor of new building and a room in the basement

37. 140

39. 24

41. 106 seats at work tables

10 upholstered, wooden-armed chairs

b) Total potential capacity of shelving (linear metres or volumes)

42. $1806 \mathrm{~m}$

43. Main reading room $: 1054 \mathrm{~m}$

44. $100 \mathrm{~m}$

45. $652 \mathrm{~m}$

(Electronically-operated high-density mobile shelving)

48. 1.5

\section{c) Mechanical features}

49. Motor-operated high windows

Electric air conditioning

50. Gas-fired central heating

51. 195 suspended metal-housed low level fluorescent lights match the steel beams and central steel tree

52. Building materials selected for acoustic qualities. Interior surfaces of outer walls are panels of acoustic brick whitewashed to preserve their absorbent quality

53. Lift outside second library exit

54. Books transported by trolley

55. 3M security system includes electronic tagging for books, alarmed doors and continuous video surveillance

56. Voyager automated library management system with self-issue machine

57. Networked and wireless facilities

58. Electronic door access

\section{SCHEDULE OF THE BUILDING PROCESS}

59. 1996

60. Presentation by architect 22 April 1998

61. April-June 1999

62. June 1999 
63. June 1999-December 2000

64. December 2000

65. January 112001

\section{E COSTS}

70. The library was part of a $f 6.67$ million building project. Total cost of new building (n.b. not just the library) $\mathrm{f} 6.67$ million. 


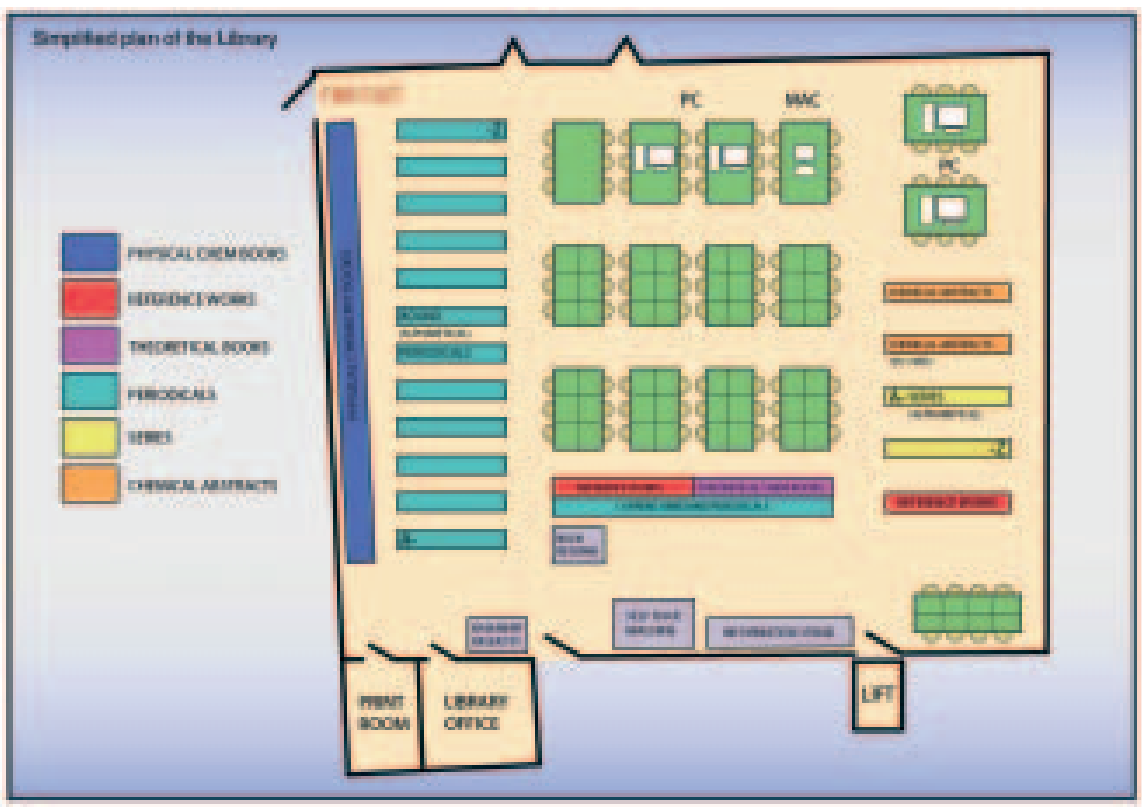

Department of Chemistry Library

Floor plan 

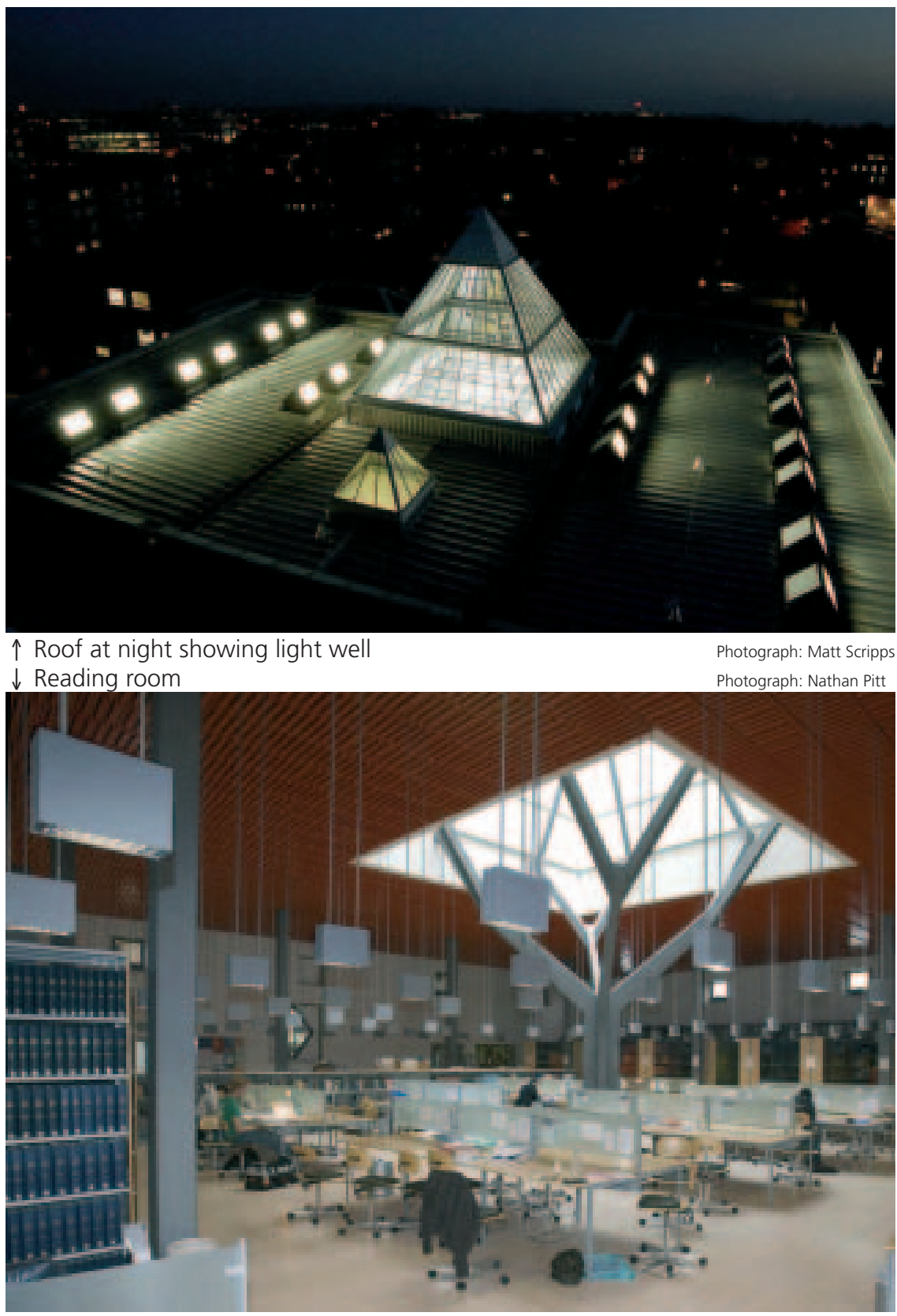

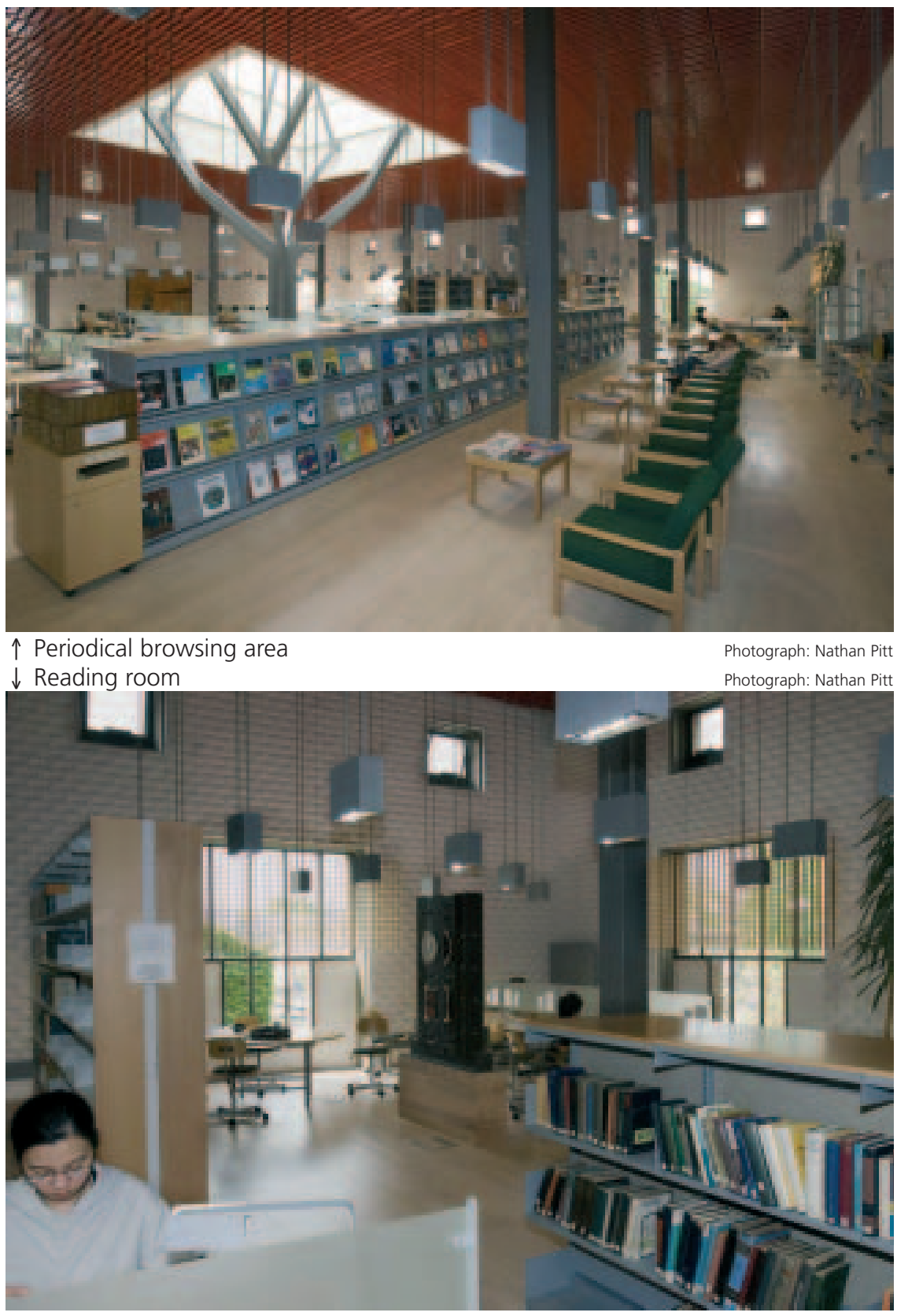


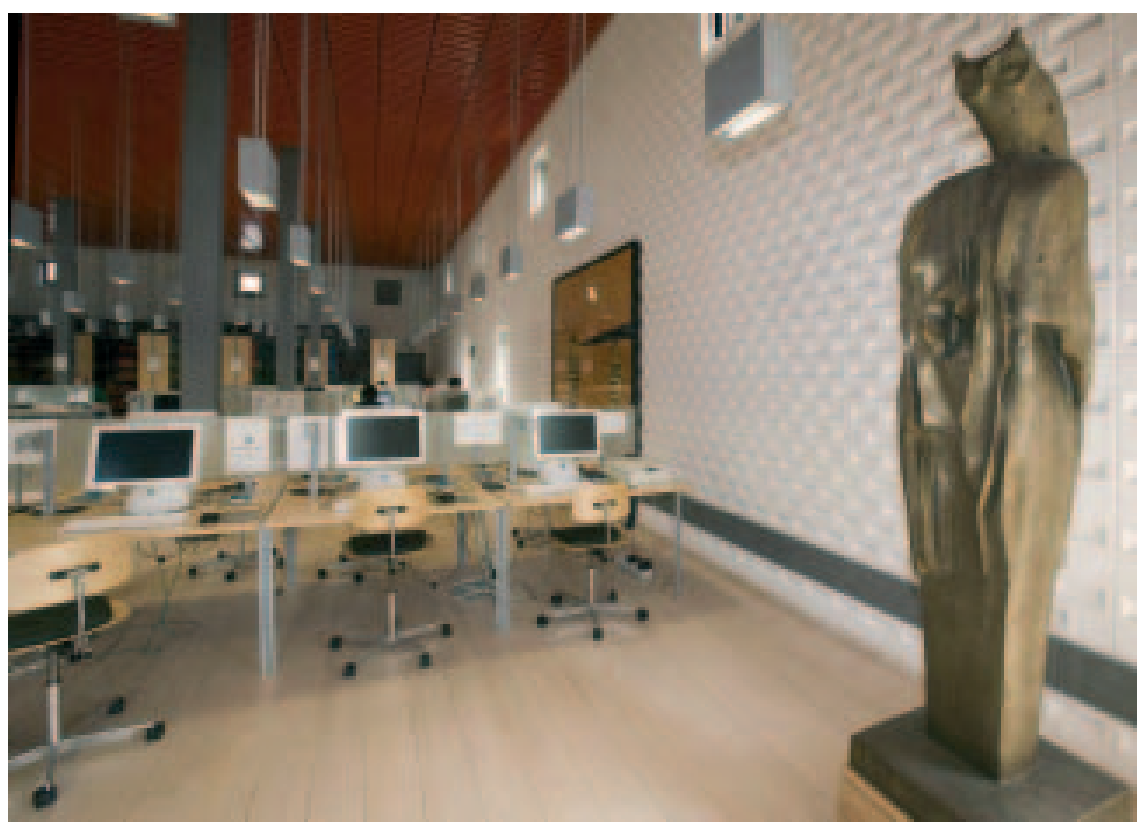

Chemistry computers and statue of Minerva

Photograph: Nathan Pitt 


\section{Institute of Criminology - Radzinowicz Library}




\section{A GENERAL INFORMATION ABOUT THE LIBRARY}

a) Name and address

1. Criminology Collection

2. Radzinowicz Library

3. Institute of Criminology

Sidgwick Avenue

Cambridge, CB3 9DT

United Kingdom

4. Phone: 00441223335386

Fax: 00441223335356

E-mail: crimlib@hermes.cam.ac.uk

5. Mary Gower

6. Mary Gower

b) Population served

Staff and students at Cambridge University and visitors with interest in criminology

7. 550

8. 67 at Institute

9. 56

10. 54

c) Conditions of the library (before the new project)

Since it was founded the Institute had been based at 7 West Road, a Victorian villa. Even with 'temporary' extensions the house became too small for the present activities of the Institute and the accommodation was poorly matched to the Institute's activity patterns. A new, purpose-designed building was long overdue.

12. 46

13. 56,000 books, 16,000 pamphlets, 400 periodicals (200 'live')

14. 45,000 open access books, 16,000 pamphlets, 350 periodical titles

15. 7,000 books, 50 periodical titles

16. 3.4

17. 57.75 hours per week

49 weeks per year 


\section{B THE NEW BUILDING: AIMS AND FEATURES}

\section{a) Architect(s)}

18. Allies and Morrison

19. Jenny Lovell (latterly Nicholas Champkins)

20. New building: yes

\section{b) Aims of the new building}

21. Building designed to meet the long and short-term needs of research and postgraduate studies at the Institute. The Library houses an outstanding criminological collection and is approximately 3 times the size of the old one with seating for 85 readers. Special Room for historic and rare books.

\section{c) Special Features}

22. The Institute of Criminology is situated on the Sidgwick Site in Cambridge, located to the East of the Raised Faculty Building. To the South, the site is bounded by the lecture block that was to be the tallest building on the Site and the first of the academic facilities by Casson Conder Architects, completed in 1959. The Faculty of Law (Foster and Partners, 1995) occupies the Northern boundary of the site.

The proposed Institute of Criminology is an integral part of the wider masterplan for the whole of the Sidgwick Site, a response to accommodation pressures, and a need to make a coherent whole out of the increasingly disparate built elements that have accumulated over 40 years. The approach taken has grown from studying Casson Conder's original vision for the Sidgwick Site; a modern reinterpretation of the historic collegiate typology where fluid, non-hierarchical public spaces replaced enclosed private courtyards.

The project follows Casson Conder's belief that the public realm between buildings is as important as the more private spaces they serve. These ideas have informed the choice of site for the new Institute of Criminology; in terms of the building's massing, orientation and connection to the rest of the site facilities. The location can be seen as part of a legacy of intention; the Raised Faculty Building surrounded by a 'necklace' of lecture halls and faculty buildings as part of the site master plan. The building's entry is located off a new pedestrian axis running East from the Faculties of Divinity 
and History. The orientation and massing also create a new enclosed garden court to the East of the Raised Faculty Building

23. Internally the four floors of accommodation house a variety of research, administrative and library spaces (the foremost Criminological library in the country): these are connected via open staircases providing informal connections between different floor levels. The main teaching and social spaces are accommodated at basement level, the floor of which also extends under the courtyard. Here, four circular rooflights punctuate the landscape to allow daylight into the interior, while a single line of roof glazing lights the main circulation route that runs parallel to the façade.

The simple rectangular plan is subverted on the North-East corner by a projecting entrance pavilion which also contains on its upper floors the Institute's main meeting room and staff room. While sharing the same material vocabulary as the body of the building - pre-cast concrete and dark grey anodized aluminium - the pavilion breaks out of the systematic repetition of the main elevations to make a more specific response to its location. The main body of the façade is composed of fixed full-height windows alternating with vertical panels of louvres. Behind these are shutters that can be opened to provide natural ventilation to individual office spaces. The simple rhythm of the façade is constant throughout the length of the building but adjusts in response to the presence of the library where more glass, and shading, is introduced. The library is identified as the 'heart' of the Institute.

The building has an in situ concrete frame with a unitised cladding system designed as a modular structure made up of anodised aluminium panels with pre-cast concrete inserts. This system then develops into a series of layers, both vertical and horizontal. A typical bay is made up of three layers; the glass line is seen as the back layer and the anodised aluminium as the front. These two layers are then bridged by a deep precast concrete insert, which forms the reveal for the window. The precast insert is intended to provide a visual foil to the aluminium panel but also allows reflected light back into the internal spaces. The insertion of a metal plate as a lining to the north - but not the south - facing reveals of the concrete panels, provokes a different reading of the building depending on the direction from which it is approached.

The internal planning and finishes of the building are designed to reflect the Institute's desire to present a light and open internal environment for 
research and academic staff. Full height doors and glazed panels to each office space allow the building to be naturally cross ventilated with good natural light levels. Within significant spaces of the building the brightly coloured panels (which also form individual cupboards and storage within offices) are replaced with Walnut veneer or Maple depending upon the nature of the space, academic or social.

\section{TECHNICAL INFORMATION ABOUT THE NEW BUILDING}

\section{a) Floor area (in sq metres) for questions 24 to 33}

24. $3370 \mathrm{sq} \mathrm{m}$

25. $710 \mathrm{sq} \mathrm{m}$

26. AV presentation and communication facilities are provided for the two 40 person seminar rooms at basement level. These can be reconfigured to give a large single presentation space when required. The building has the data outlet facilities for AV presentation in both academic offices, meeting rooms and other presentation spaces

27. 8 dedicated computer terminals are provided within the Library alongside data and power outlets located at library tables and study carrels for casual use.

28. Historic and Rare Books collection is provided with restricted access and a gas suppression system, $12 \mathrm{sq} \mathrm{m}$

29. 2 No. 40 person seminar rooms are provided at basement level alongside other main teaching and social spaces. These seminar rooms are separated by a demountable acoustic screen and can be combined to form a large teaching space

30. Both library and academic areas allow for temporary and permanent exhibitions via screens, display cases or frames. The entrance hall has an ongoing sequence of exhibitions.

32. At basement level as public and student social space is associated with the seminar rooms with drinks facilities, at second floor a staff common room gives a relaxed and social environment for meetings and events with a teapoint. A teapoint is also provided with the Institute Boardroom.

33. 2 Offices in Library + Enquiry desk area

34. 600 metres of shelving

36. 5 floors - Basement and Library (2 floors) accessible to public 


\section{85}

39. 8 public terminals in Library - all desks have power and data for laptops

40. See above

\section{b) Total potential capacity of shelving (linear metres or volumes)}

42. $1950 \mathrm{~m}$

43. $1350 \mathrm{~m}$

44. $600 \mathrm{~m}$ rolling stack

48. 3.4

\section{c) Mechanical features}

49. The building is designed to be naturally ventilated with occupant control of each part of the internal environment. The exposed concrete frame is designed to give 'coolth' to the building - storing heat during the day and passively releasing this energy at night. This ensures that the internal environment to the building is stable with no peaks or troughs in temperature. To maximise the performance of the building fabric the elevation has manual occupant controlled vent panels, protected by louvres, these allow ventilation both at night and in wet weather, 'purging' the concrete frame ready for the next day. Where high occupant numbers are expected in the seminar rooms a mechanical system is employed using a raised floor air plenum and heat recovery system.

50. The building is heated using perimeter trench heaters generally with radiators in key entrance spaces.

51. The building fabric is designed to maximise natural light deep into the building plan with high windows and rooflights. All artificial lighting is on timed circuits to minimise energy consumption.

52. The building's internal environment has been carefully designed to give good acoustic separation between offices with acoustic control via panels in public areas. The seminar rooms have angled double glazed internal windows allowing light and views but controlling reverberation when in use.

53. An 8 person passenger lift serves all floors

54. A book hoist serves the library areas

55. $3 \mathrm{M}$ security gates and security camera in Library

56. Yes

57. Flood wired Cat 6 structured cabling for both telephony and data. 173 data points in Library and Library Offices. 


\section{SCHEDULE OF THE BUILDING PROCESS}

59. Briefing and design development started in 2000

62. July 2002

63. 2 years

64. Furnishing the Library June / July 2004 collection moved during 2 weeks in August 2004

65. Open September 2004. Official opening by Lord Woolf, May 2005

\section{E COSTS}

70. Construction cost $f 9$ million

\section{AWARDS}

Shortlisted for the 2006 RIBA Award. 


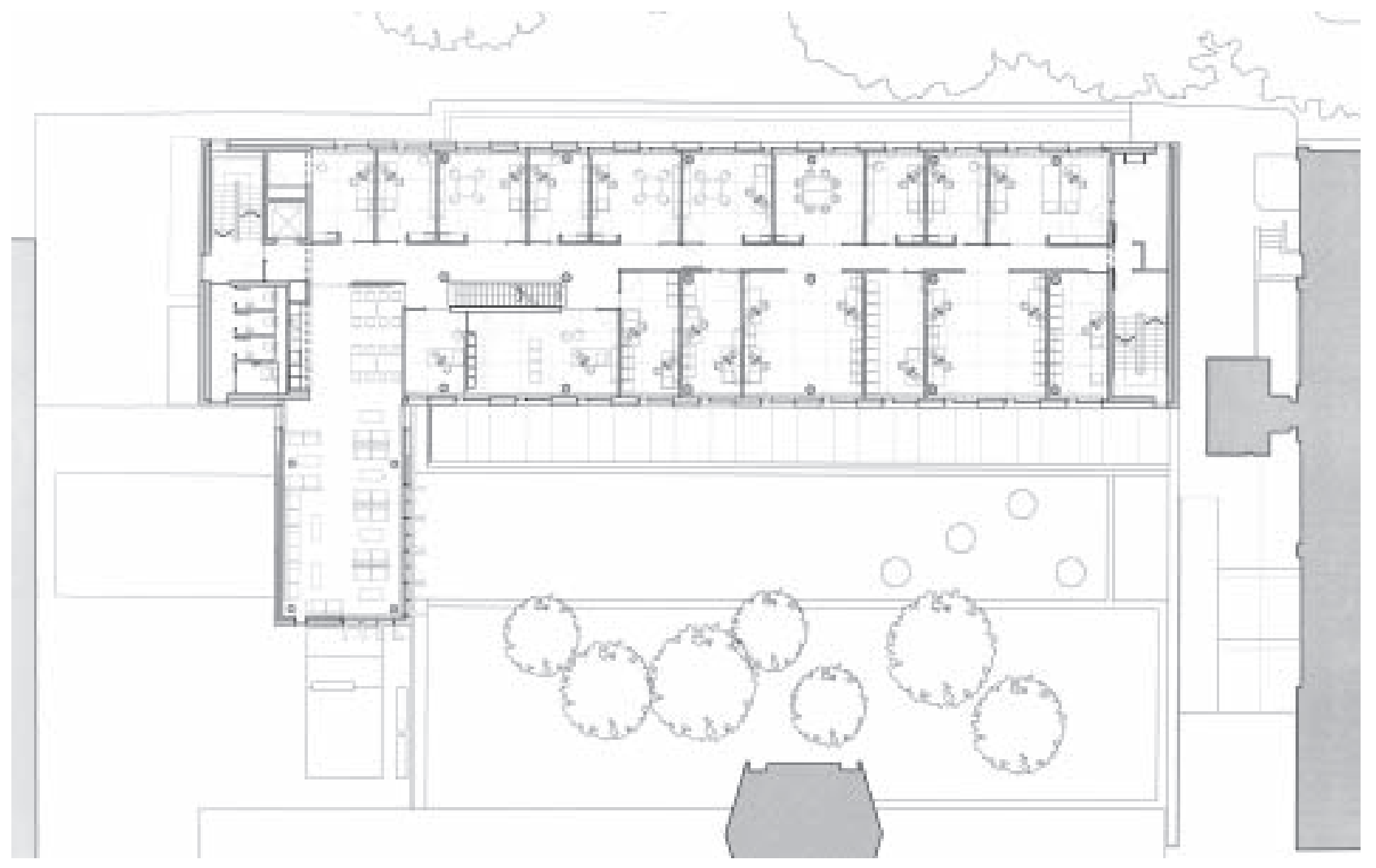

Institute of Criminology - Radzinowicz Library Ground plan 


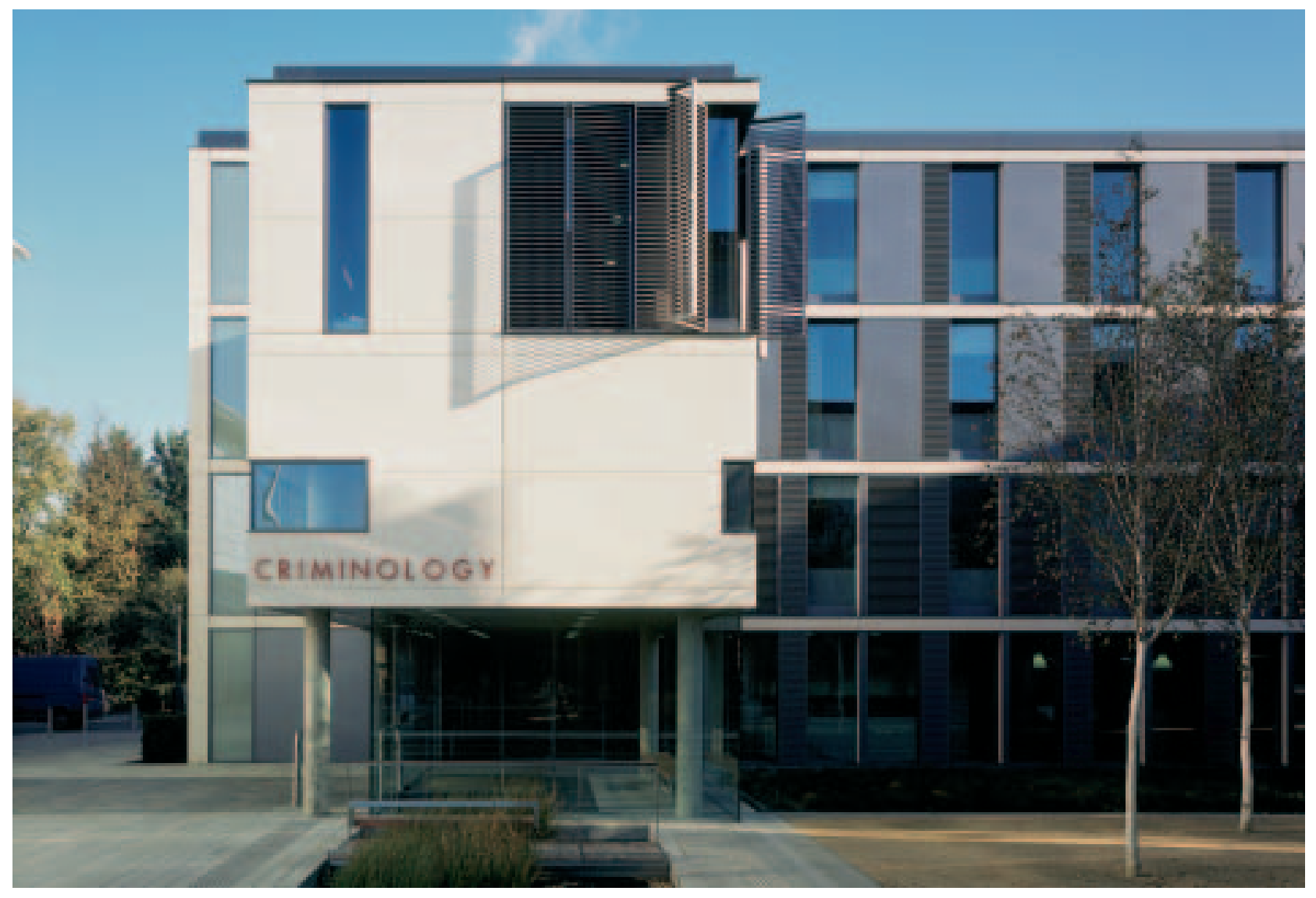




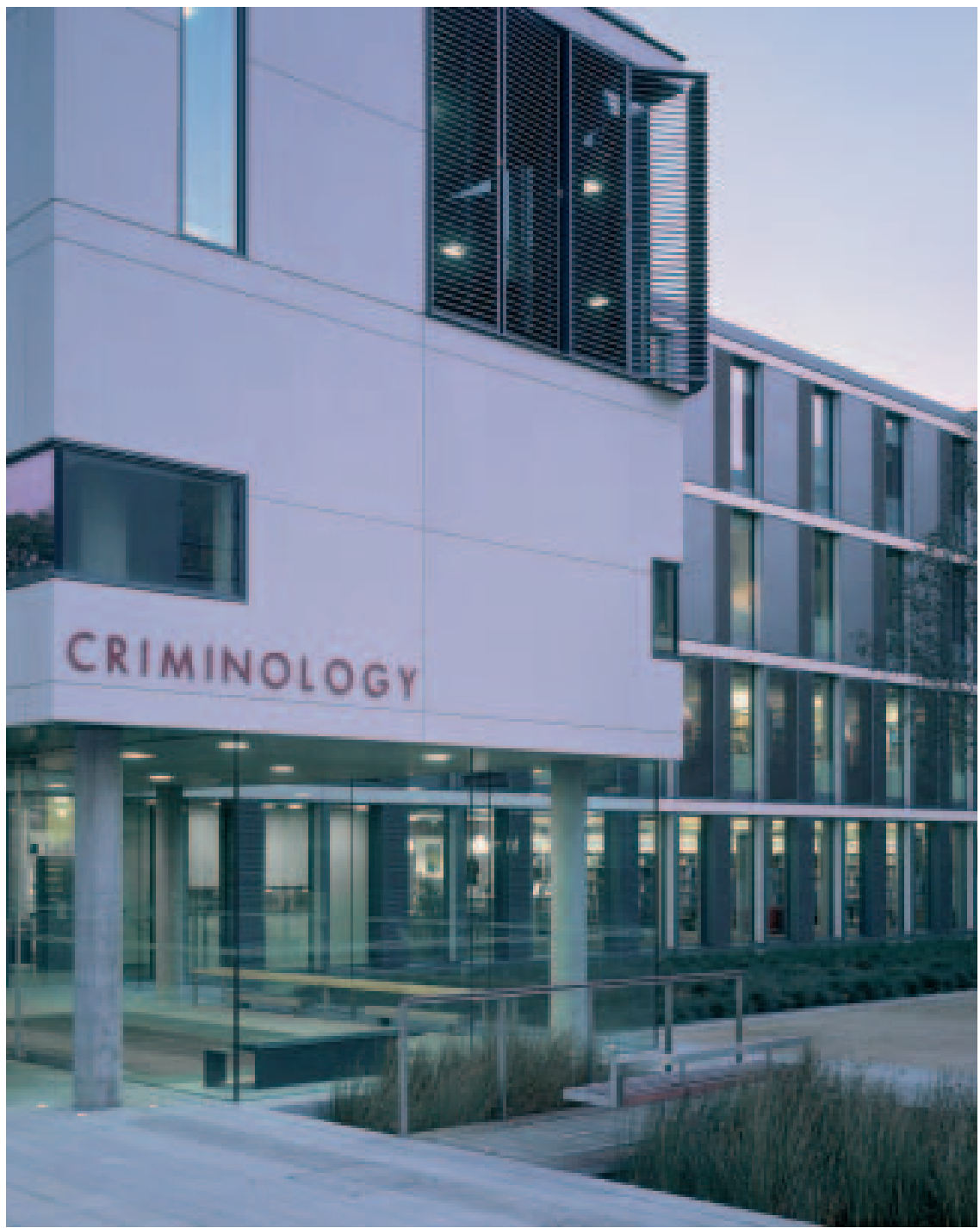

Institute of Criminology - Radzinowicz Library Photographs: Dennis Gilbert 


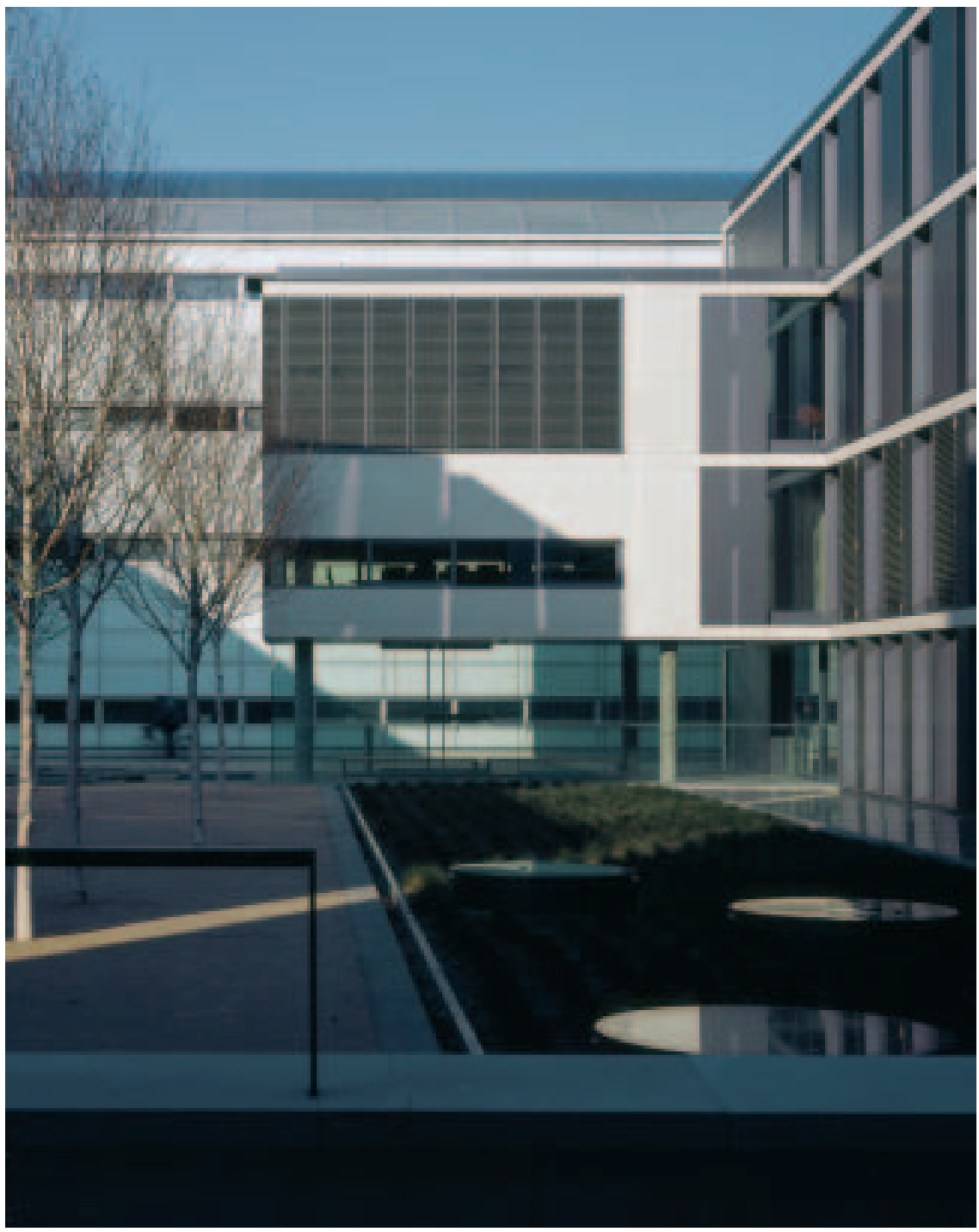

Institute of Criminology - Radzinowicz Library Photograph: Dennis Gilbert 


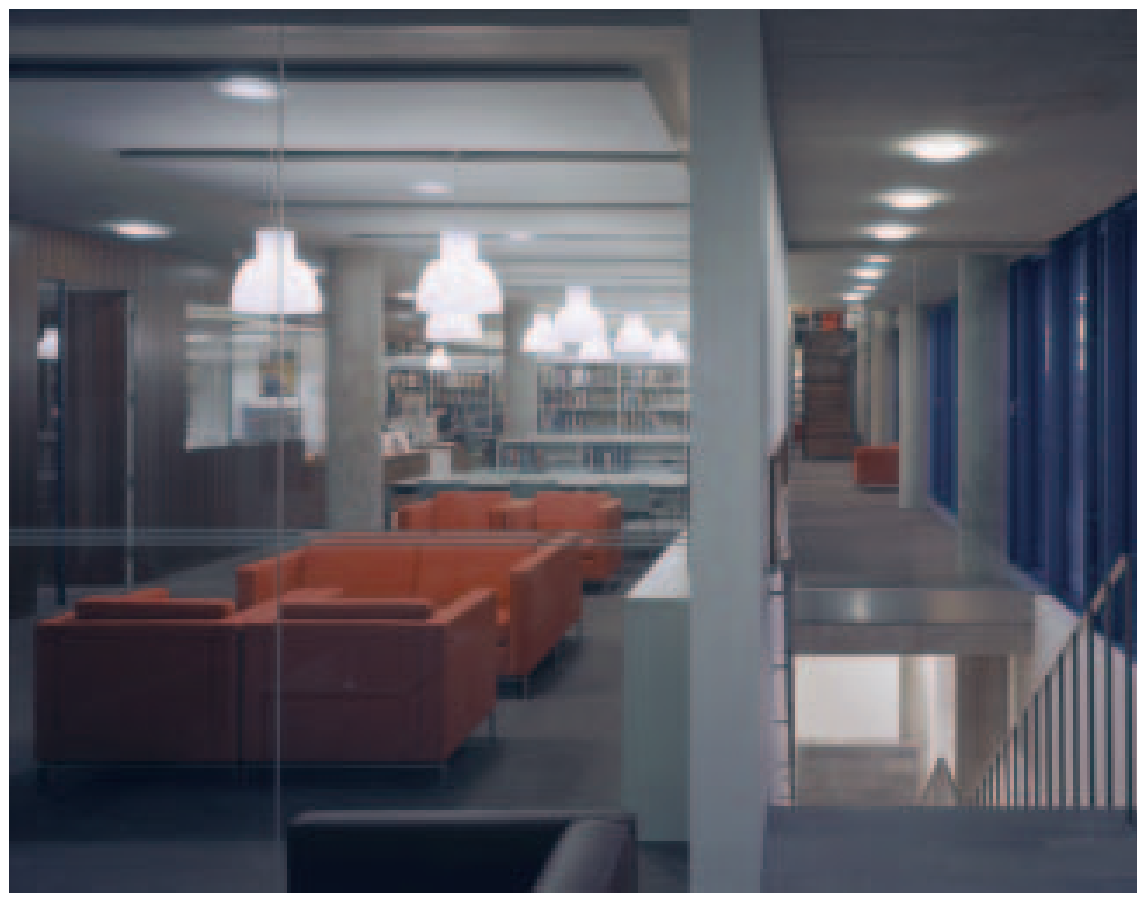

Institute of Criminology - Radzinowicz Library Photograph: Dennis Gilbert 
Faculty of Education Library 


\section{A GENERAL INFORMATION ABOUT THE LIBRARY}

a) Name and address

1. University Department Library

2. Faculty of Education Library

3. 184 Hills Road, Cambridge CB2 2PQ

4. Phone: 01223767700

E-mail: library@educ.cam.ac.uk

5. Angela Cutts

6. Angela Cutts

b) Population served

7. 2,000 (approx.)

8. 1,050

9. 1,200

10. 8 Professors, 1 Reader, 60 Academic Staff, over 100 support staff

c) Conditions of the library (before the new project)

11. There were 2 physically separate Libraries

12. 97

13. $1521 \mathrm{~m}$ in two Libraries

14. 1180

15. 341

16. 7.6

17. Each of the two Libraries opened for 46.5 hours per week during term time and 279 days per year.

\section{B THE NEW BUILDING: AIMS AND FEATURES}

\section{a) Architect(s)}

18. BDP (Building Design Partnership)

20. New building: yes

\section{b) Aims of the new building}

21. The new building was constructed to bring together the Faculty of Education which was previously accommodated on 5 sites across Cambridge. The 
Library within the new building was planned to accommodate collections previously held in 3 Libraries.

\section{c) Special Features}

22. The Library is located in the heart of the new Faculty building.

23. The library is made of a Glulam timber frame. This makes for a lightweight building whose structure is clearly expressed through the exposed beams and columns. The frame curves up over the library, coming to rest above the top of the heavier teaching block. The library sinks partially into the ground, giving its occupants a "rabbit's eye view" of the grass outside.

\section{TECHNICAL INFORMATION ABOUT THE NEW BUILDING}

\section{a) Floor area (in sq metres) for questions 24 to 33}

25. The Library is all open plan and easily accessible to all readers

28. Archive collection for reference use

32. Not in the Library

33. 2 Library offices and Issue Desk area

34. Archive Room plus Rolling Stacks on Lower Ground Floor

35. 2 disabled toilets, no lift, ramps for disabled access

36. 3 levels (Lower Ground Floor, Ground Floor, First Floor)

37. 108

38. 5

39. 8 stand up terminals, 17 sit down terminals

41. 70

b) Total potential capacity of shelving (linear metres or volumes)

42. 1865

43. 1695

44. $56 \mathrm{~m}$

45. $114 \mathrm{~m}$

48. 9.6 (we have 2 full-time staff on temporary contracts)

\section{c) Mechanical features}

49. Yes

50. Yes 
51. Yes

53. Not in Library

55. Yes

56. Yes

\section{SCHEDULE OF THE BUILDING PROCESS}

62. April 2003

63. Finished January 2005 (21 months)

64. November 2004-January 2005

65. $4^{\text {th }}$ January 2005

\section{AWARDS}

Shortlisted for the 2006 RIBA Award. 


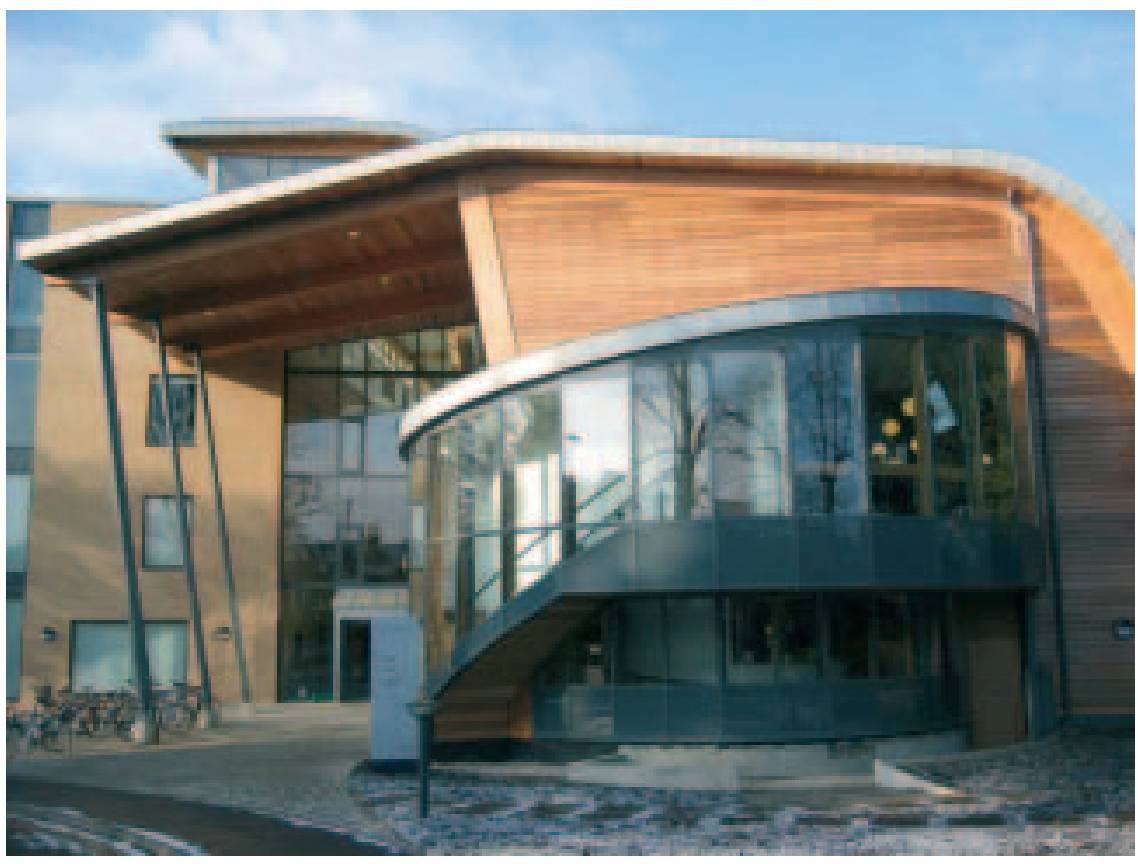

Faculty of Education library 


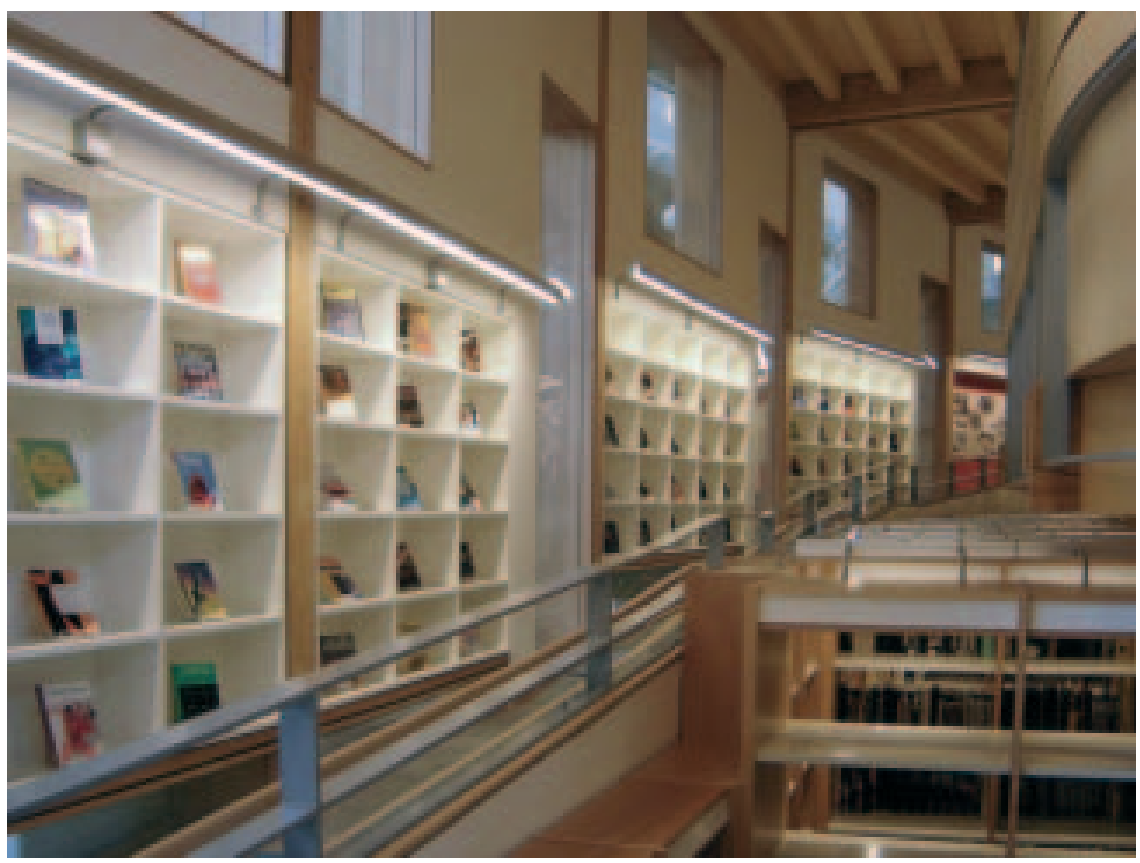

Faculty of Education library 


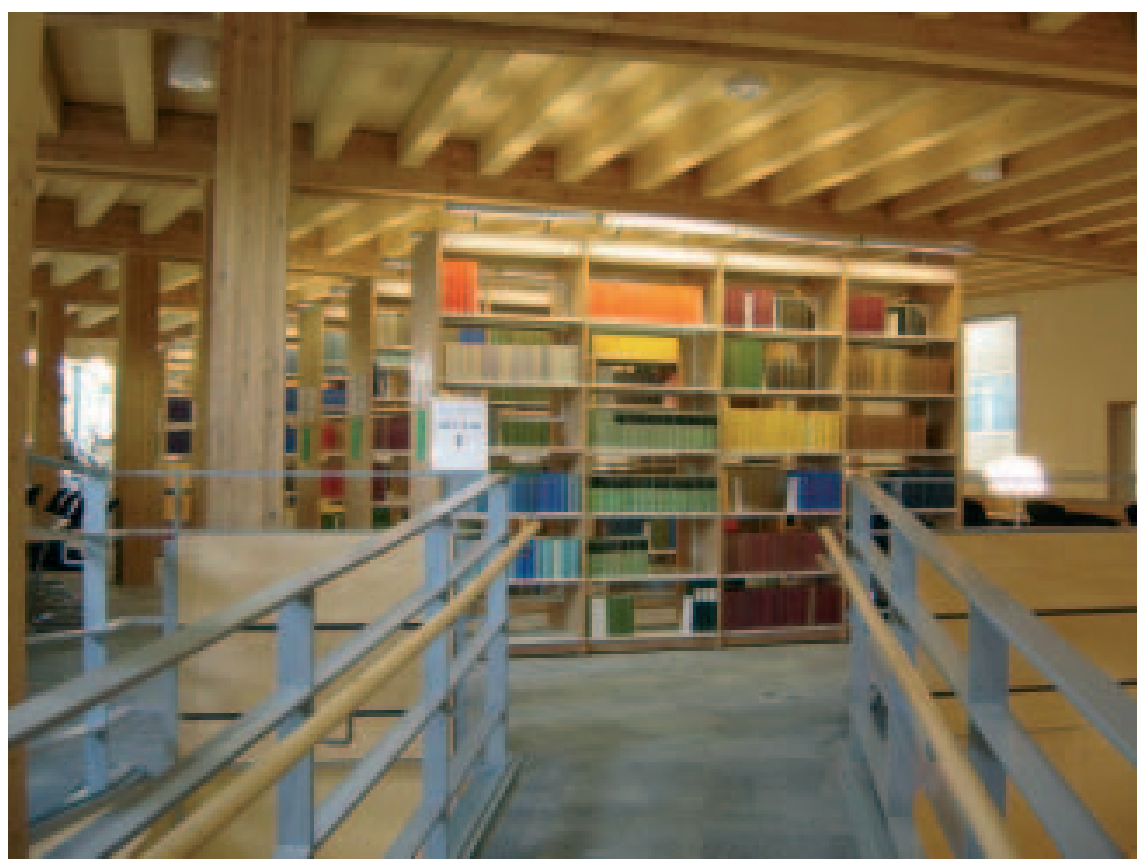

Faculty of Education library 


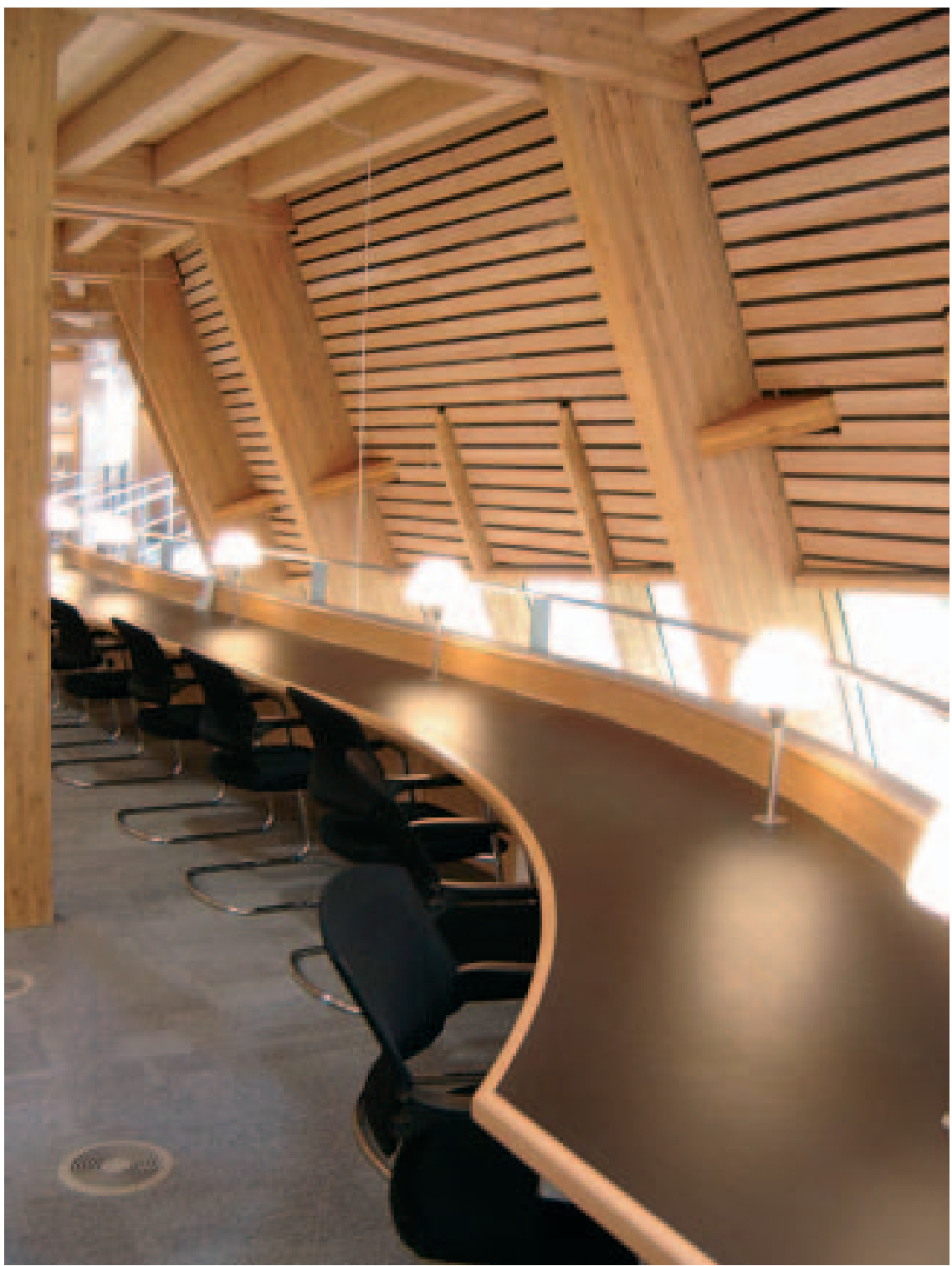

Faculty of Education library 
Scott Polar Research Institute Library 


\section{A GENERAL INFORMATION ABOUT THE LIBRARY}

a) Name and address

1. Academic Library

2. Scott Polar Research Institute Library

3. Lensfield Road, Cambridge, CB2 1ER

4. Phone: 01223336540

Fax: 01223336549

E-mail: enquiries@spri.cam.ac.uk

5. Heather Lane

6. Shirley Sawtell

b) Population served

7. 329

8. 23

10. 21

c) Conditions of the library (before the new project)

11. $462 \mathrm{sq} \mathrm{m}$

12. 36

13. $789.9 \mathrm{~m}$

14. $765.4 \mathrm{~m}$

15. $24.5 \mathrm{~m}$

16. 6.5

17. 42.5 hrs per week, 240 days per year

\section{B THE NEW BUILDING: AIMS AND FEATURES}

a) Architect(s)

18. John Miller and Partners

19. Richard Brearley, Dipl. Arch. RIBA

20. Extension: yes

b) Aims of the new building

21. More shelf-space and reader places, research study area for post-graduate students

c) Special Features

22. On a small site, by a busy road, just outside the historic city centre 
23. Very small site, circular library extension, link area and additional floor for bookstacks and reader space.

\section{TECHNICAL INFORMATION ABOUT THE NEW BUILDING}

a) Floor area (in sq metres) for questions 24 to 33

24. $298 \mathrm{sq} \mathrm{m}$

25. $298 \mathrm{sq} \mathrm{m}$

35. New lift installed, but not part of new extension

36. Three levels, all with public access. Top level designed for postgraduate use.

37. 24

39. 10

41. 41

b) Total potential capacity of shelving (linear metres or volumes)

42. $899 \mathrm{~m}$

43. $863 \mathrm{~m}$

44. $36 \mathrm{~m}$

48. 6.5

c) Mechanical features

51. Uplights custom designed by architect

53. Kone. 8 person capacity

55. Thorn Security 'Siteguard' equipment

\section{SCHEDULE OF THE BUILDING PROCESS}

62. Sept. 1997

63. 14 months

65. Nov. $20^{\text {th }} 1998$

\section{E COSTS}

67. $f 1,000,000$

68. $f 100,000$

69. $f 100,000$

70. $f 1,200,000$ 


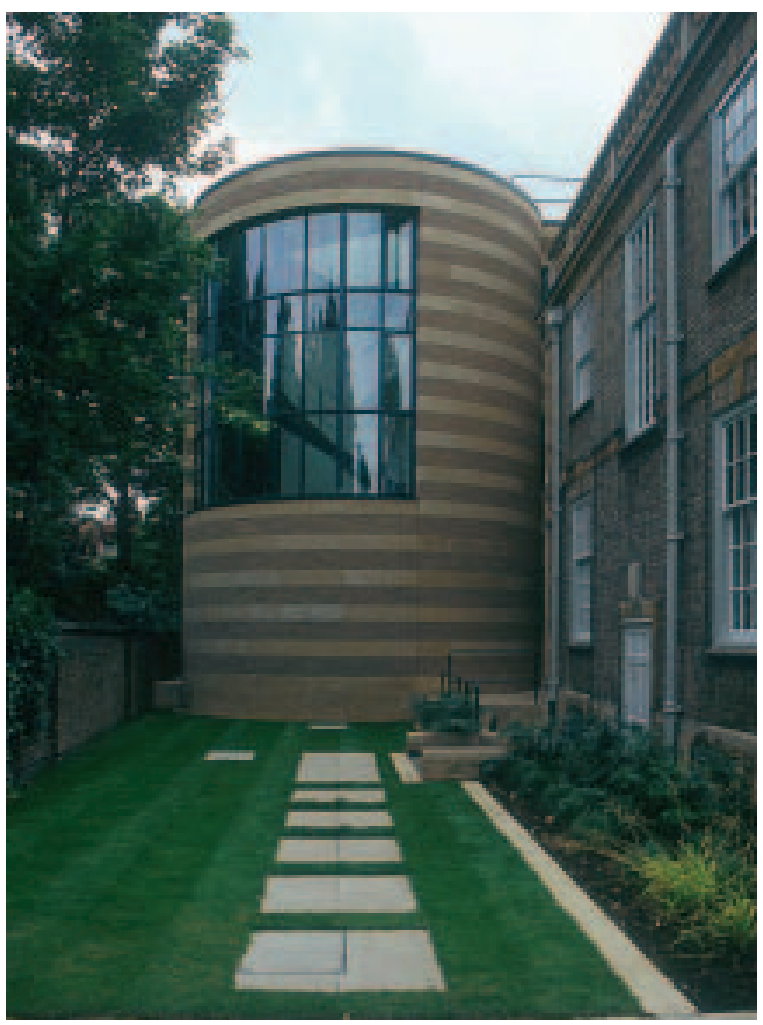

Scott Polar Research Institute

Photographs: Mark Gilbert

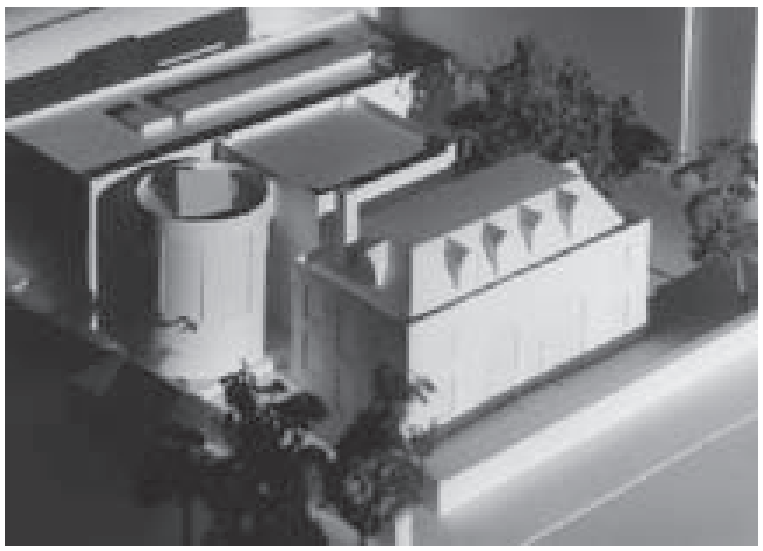




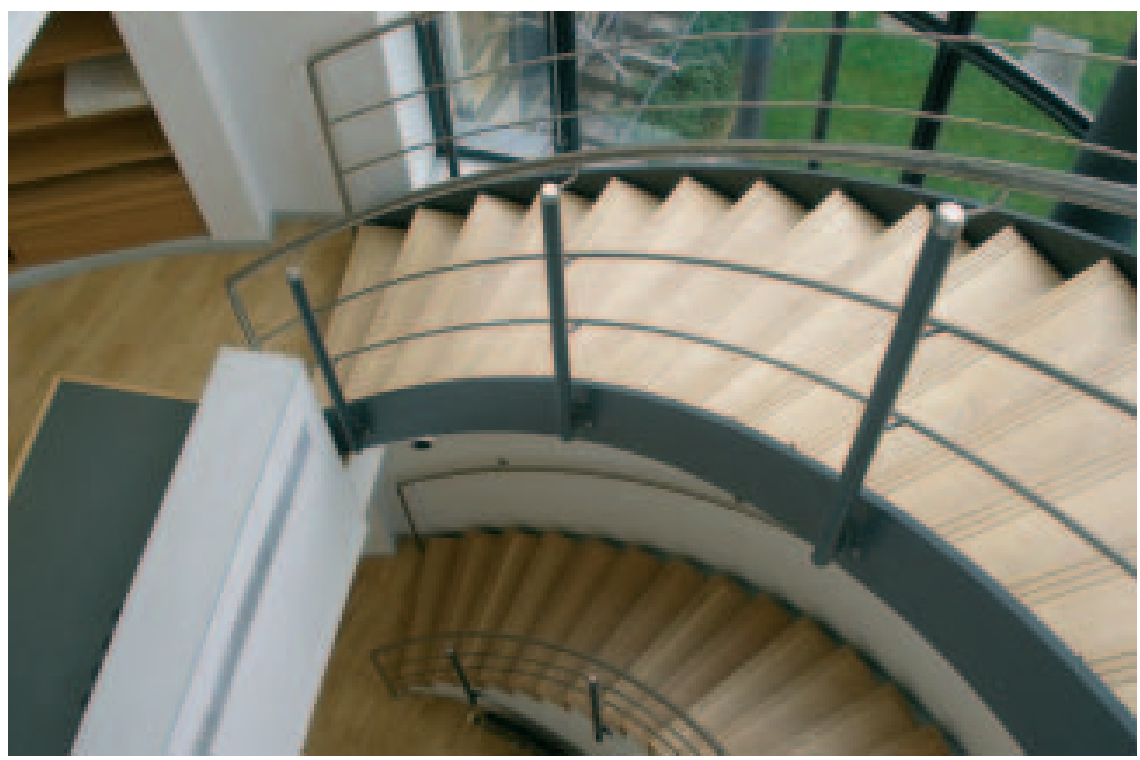

Scott Polar Research Institute

Photographs: Mark Gilbert

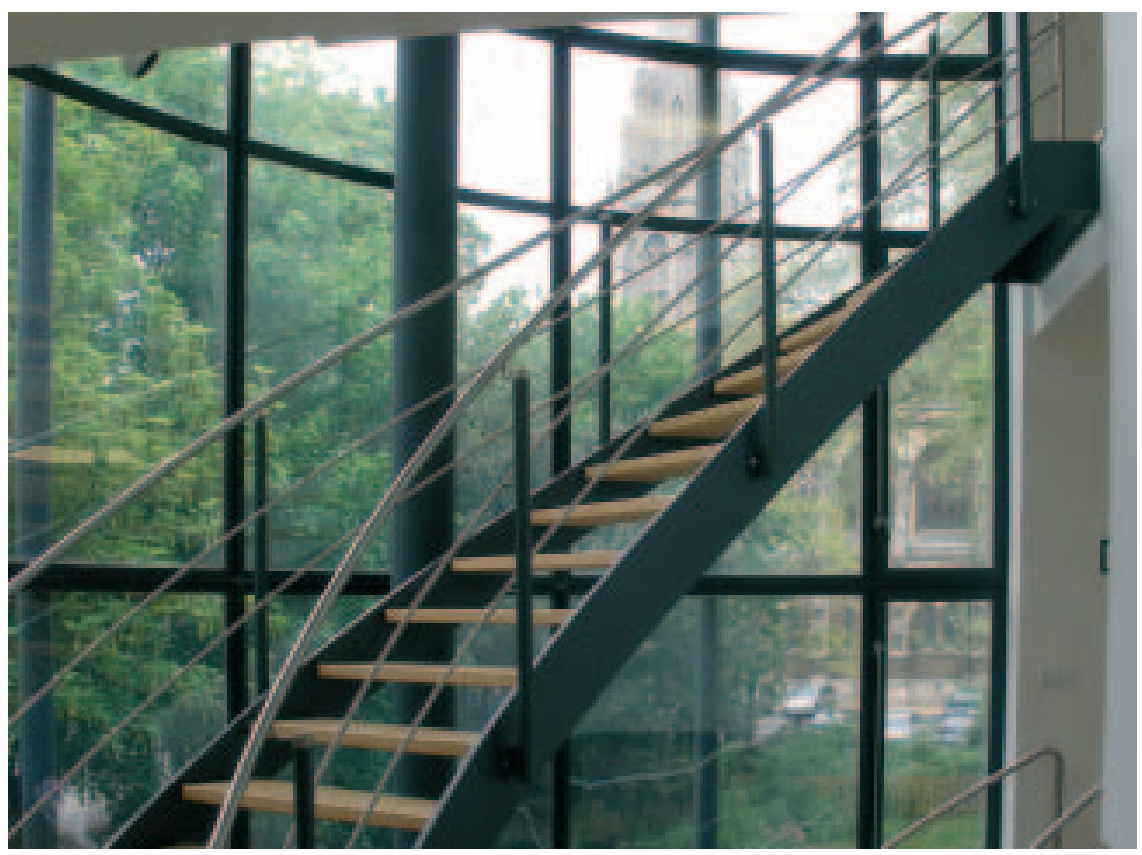



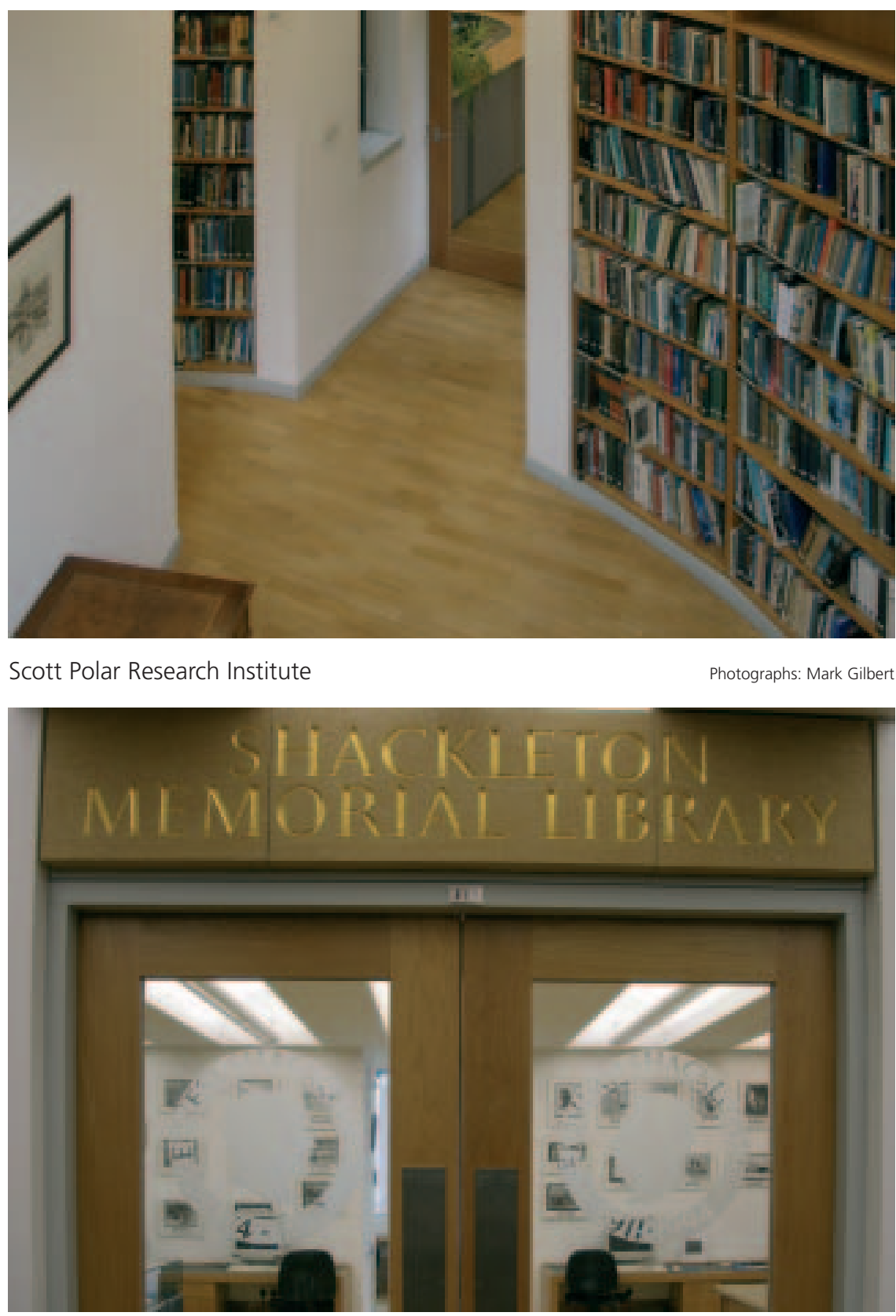
Clare College -

Forbes Mellon Library 


\section{A GENERAL INFORMATION ABOUT THE LIBRARY}

a) Name and address

1. Academic / College

2. Forbes Mellon Library

3. Memorial Court

Clare College

Cambridge CB3 9AJ

4. Phone: 01223333202

Fax: 01223765560

E-mail: library@clare.cam.ac.uk

5. Mrs Anne Hughes

6. Mrs Anne Hughes

b) Population served

7. 700

8. 600

10. 100

c) Conditions of the library (before the new project)

11. 111.5

12. 21

14. 14,000 vols

16. one

\section{B THE NEW BUILDING: AIMS AND FEATURES}

a) Architect(s)

18. Arup Associates

19. Sir Philip Dowson

20. New building: yes

b) Aims of the new building

21. In 1979 the College identified a need for a new undergraduate library, with room for more work places at which to study and adequate space for the expected future expansion of stock. 
c) Special Features

22. The library is situated in one of the College courts.

23. The library building is octagonal. The library itself is a semi-octagon, extending into the northwest corner of the remaining semi-octagon on the first floor. The East façade is stone coursing and rusticated brickwork, the West façade is white, textured pre-cast concrete and Portland stone. Two two-storey bay windows face northeast and southeast.

\section{TECHNICAL INFORMATION ABOUT THE NEW BUILDING}

a) Floor area (in sq metres) for questions 24 to 33

24. $494 \mathrm{sq} \mathrm{m}$

25. $300 \mathrm{sq} \mathrm{m}$

27. $30 \mathrm{sq} \mathrm{m}$

33. $29 \mathrm{sq} \mathrm{m}$

34. 27

35. 108

36. 2

37. 73

39. 13

41. 60

b) Total potential capacity of shelving (linear metres or volumes)

42. 25,500

43. 25,000

44. 500

46. 150

48. 2

c) Mechanical features

50. Electric

54. Book hoist

55. Plescon Security System

56. Heritage Library System 


\section{SCHEDULE OF THE BUILDING PROCESS}

59. $1980-83$

62. 1984

63. 18 months

65. $11^{\text {th }}$ June 1986

\section{E COSTS}

70. $f 1.3$ million

\section{F PUBLICATIONS:}

- Gooder, Richard: Clare College Library Cambridge, in: Arup journal, 22 (1987), no. 3 (Autumn), p. 7-12.

- Library Builders, London: Academy Editions, 1997. 


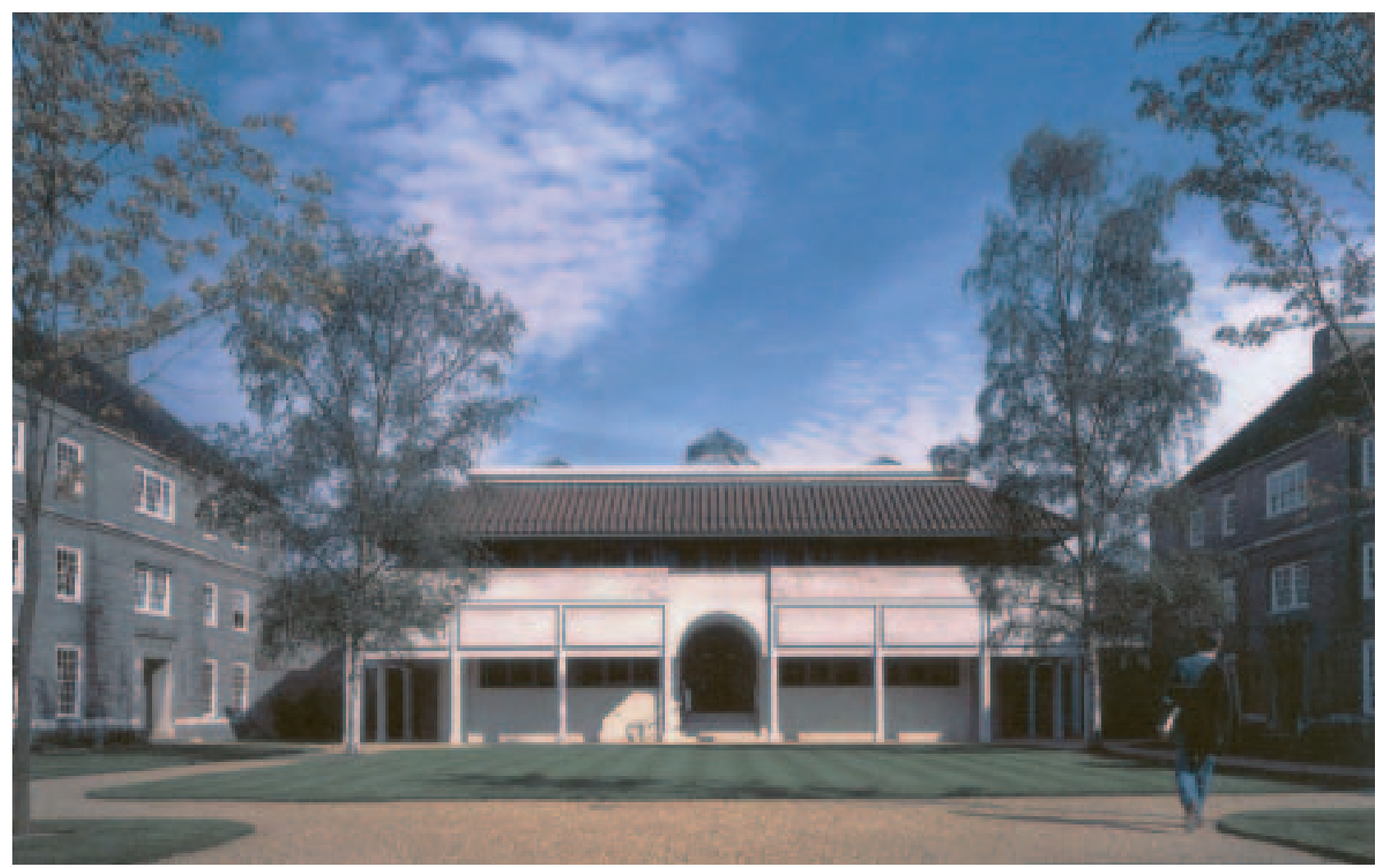

Clare College - Forbes Mellon Library West façade 


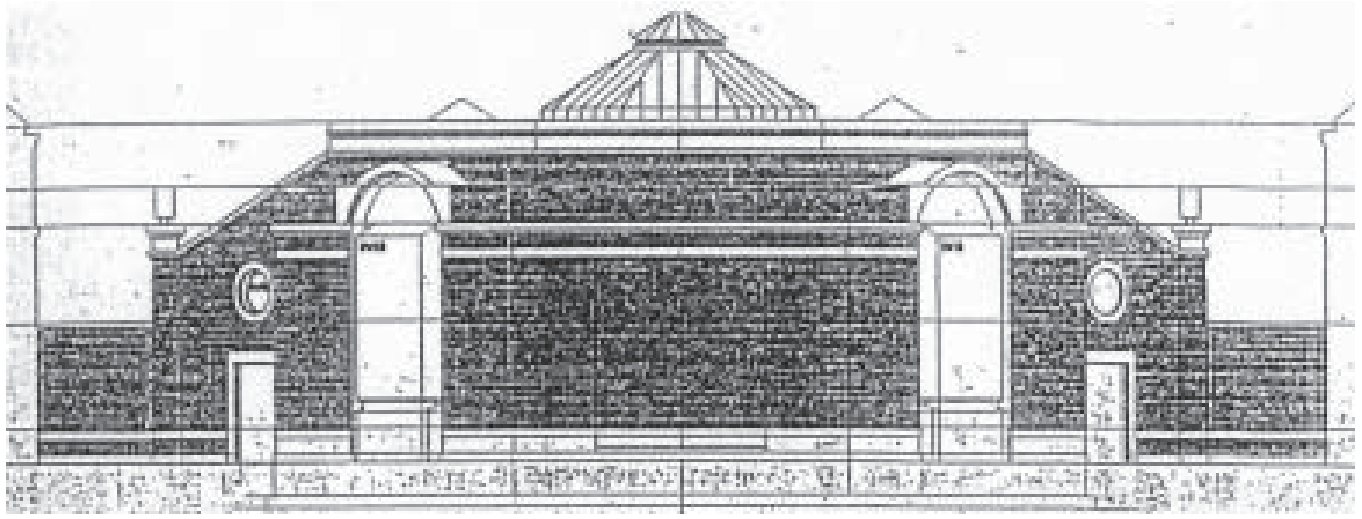

$\uparrow$ Clare College - Forbes Mellon Library, East elevation

$\downarrow$ West elevation Arup Associates - Architects, Engineers and Quantity Surveyors

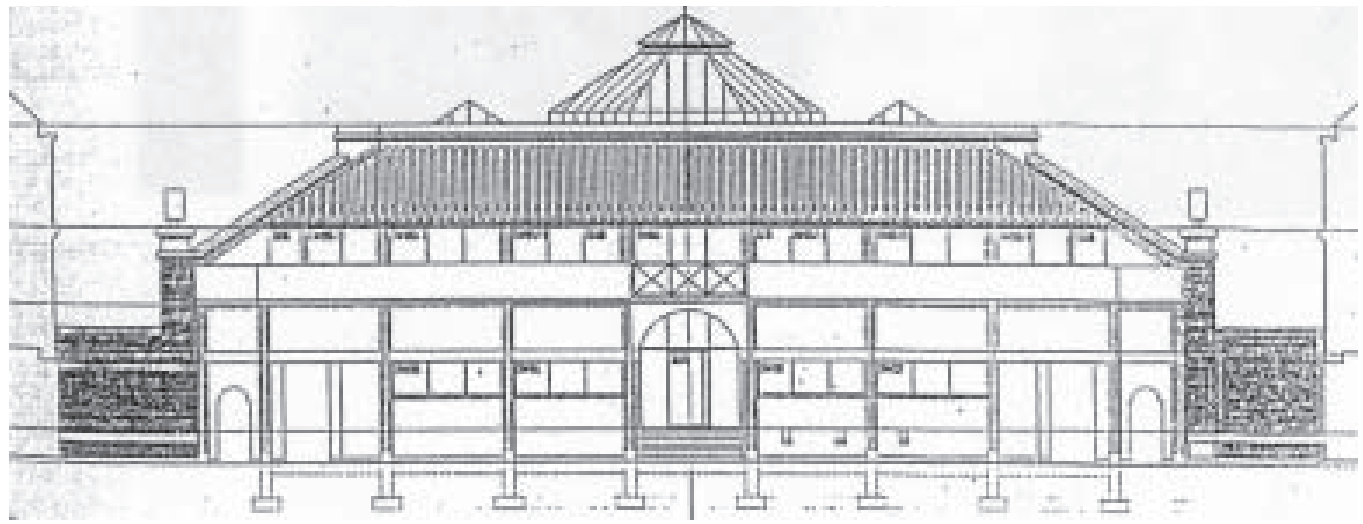




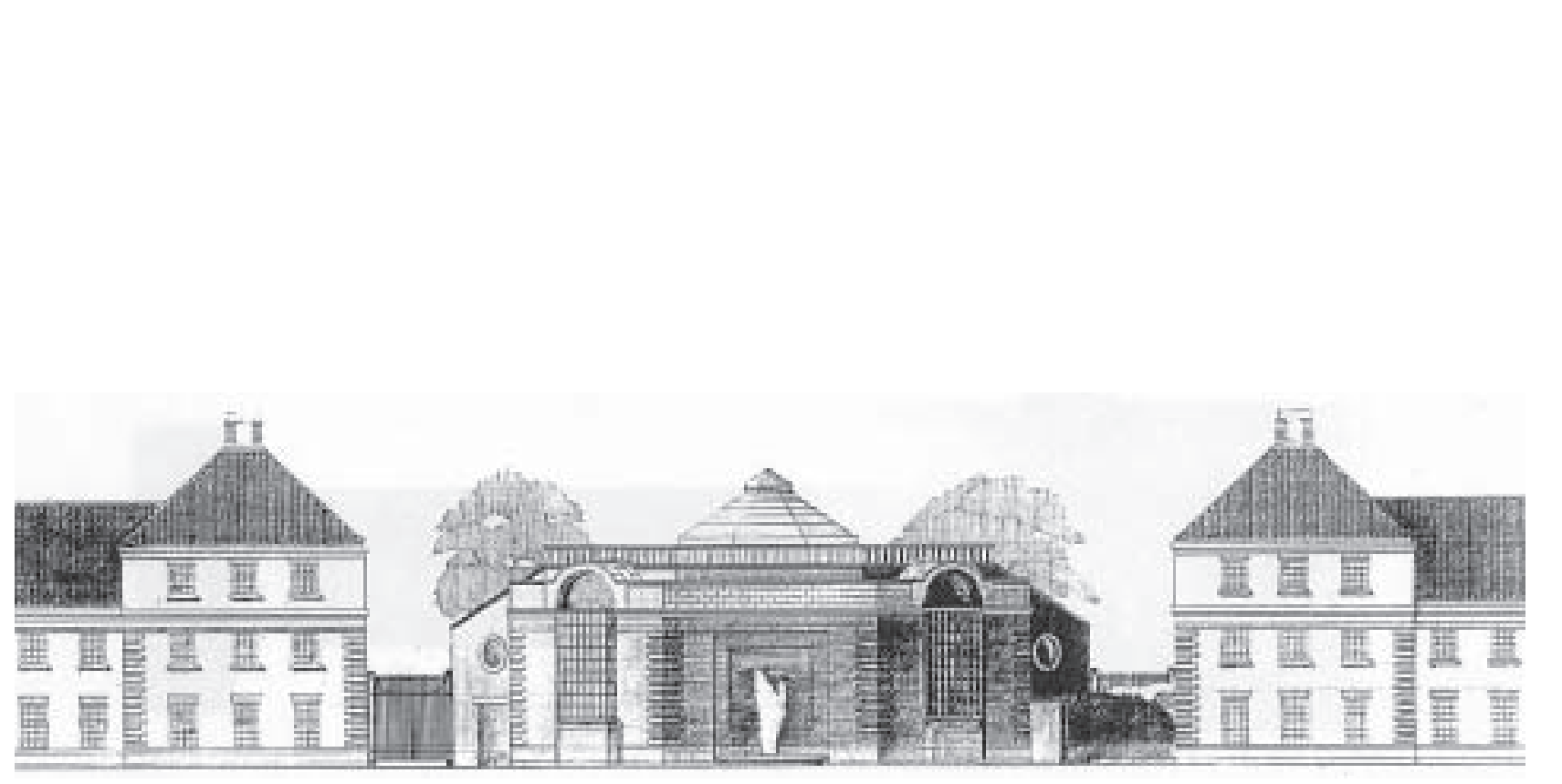

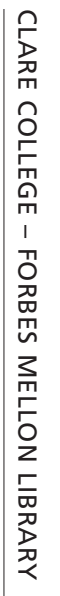

Clare College - Forbes Mellon Library

East façade

Arup Associates - Architects, Engineers and Quantity Surveyors 


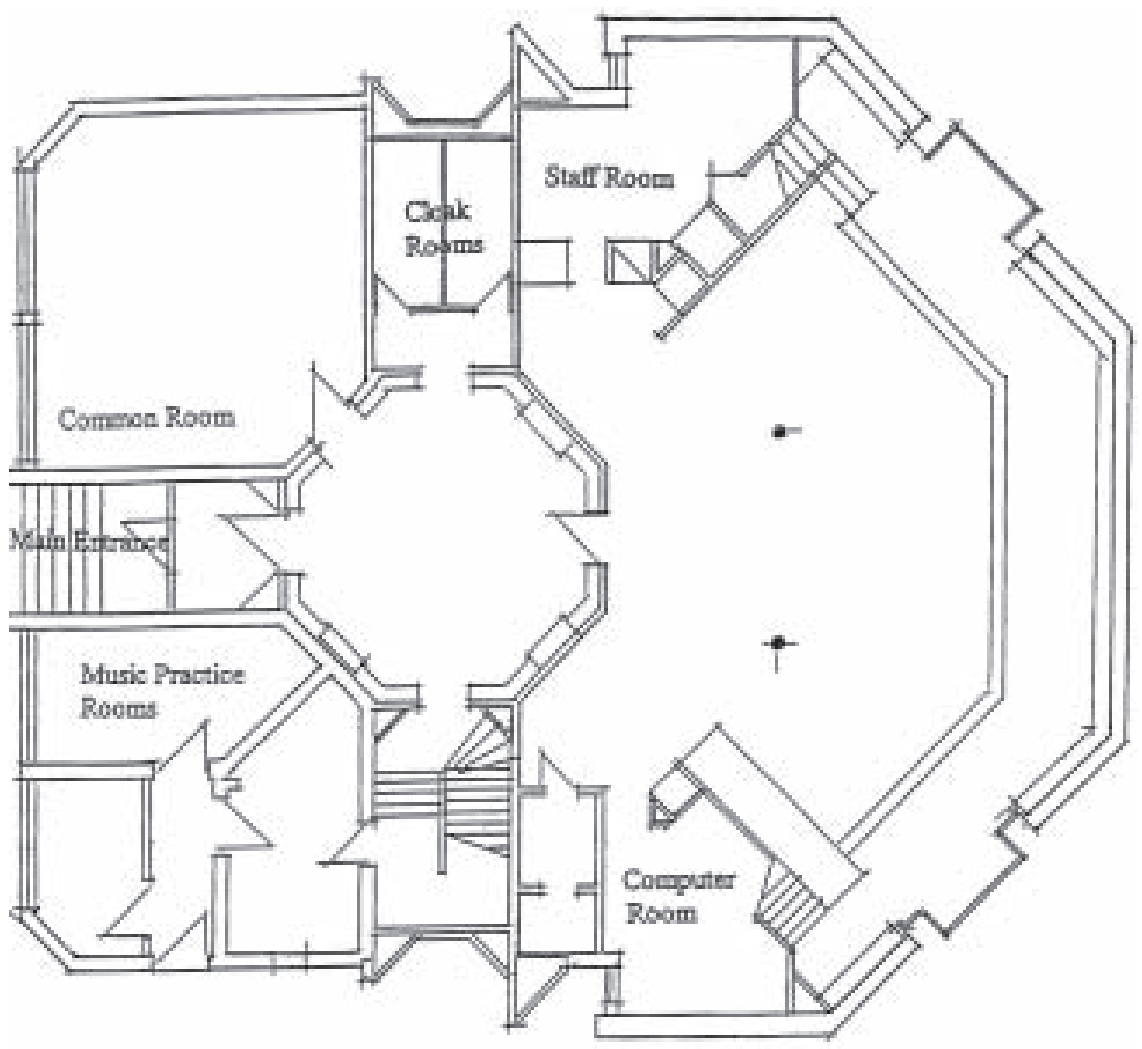

Clare College - Forbes Mellon Library

Main floor ground plan

Arup Associates - Architects, Engineers and Quantity Surveyors 


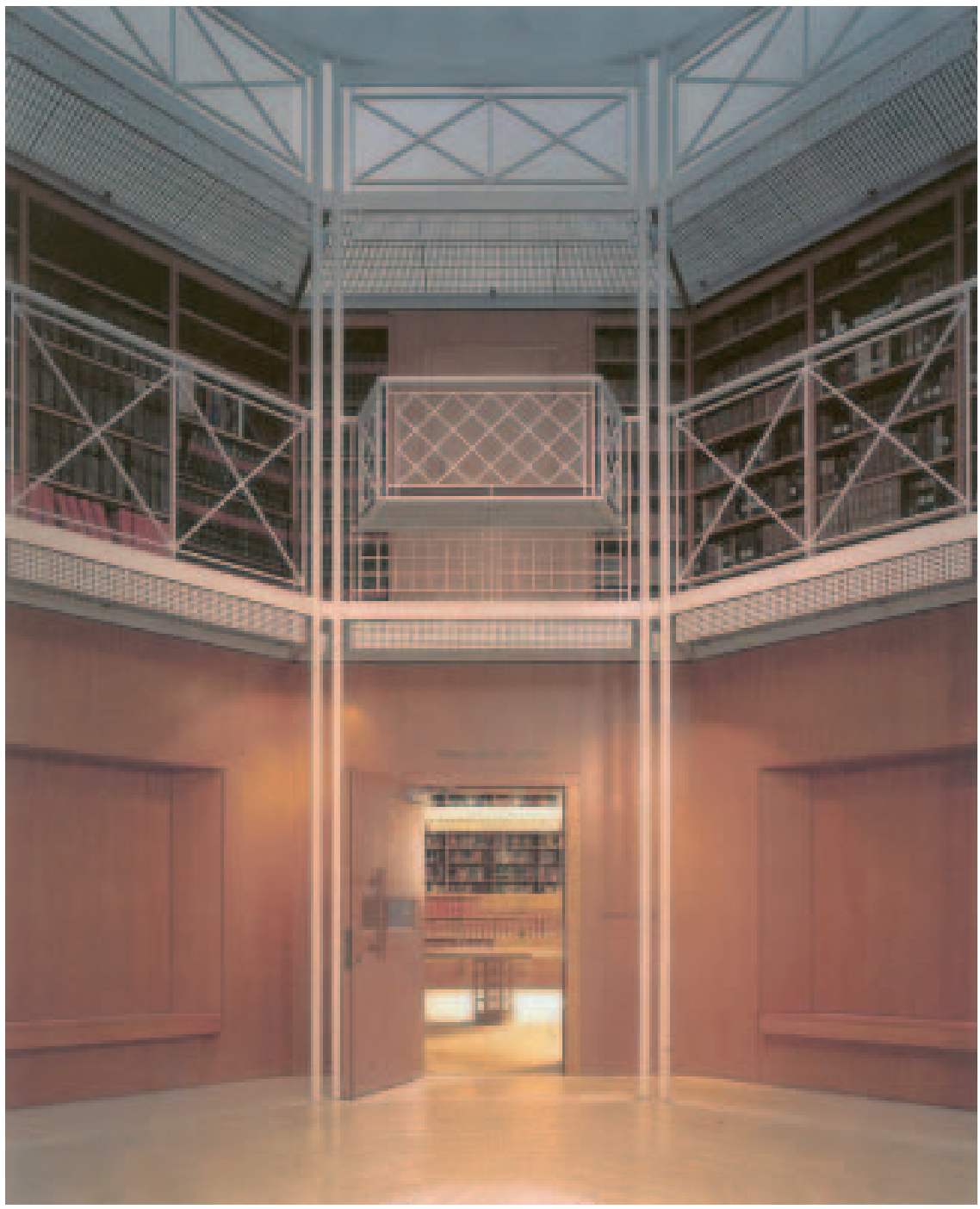

Clare College - Forbes Mellon Library Interior view of octagonal entrance hall Arup Associates - Architects, Engineers and Quantity Surveyors 


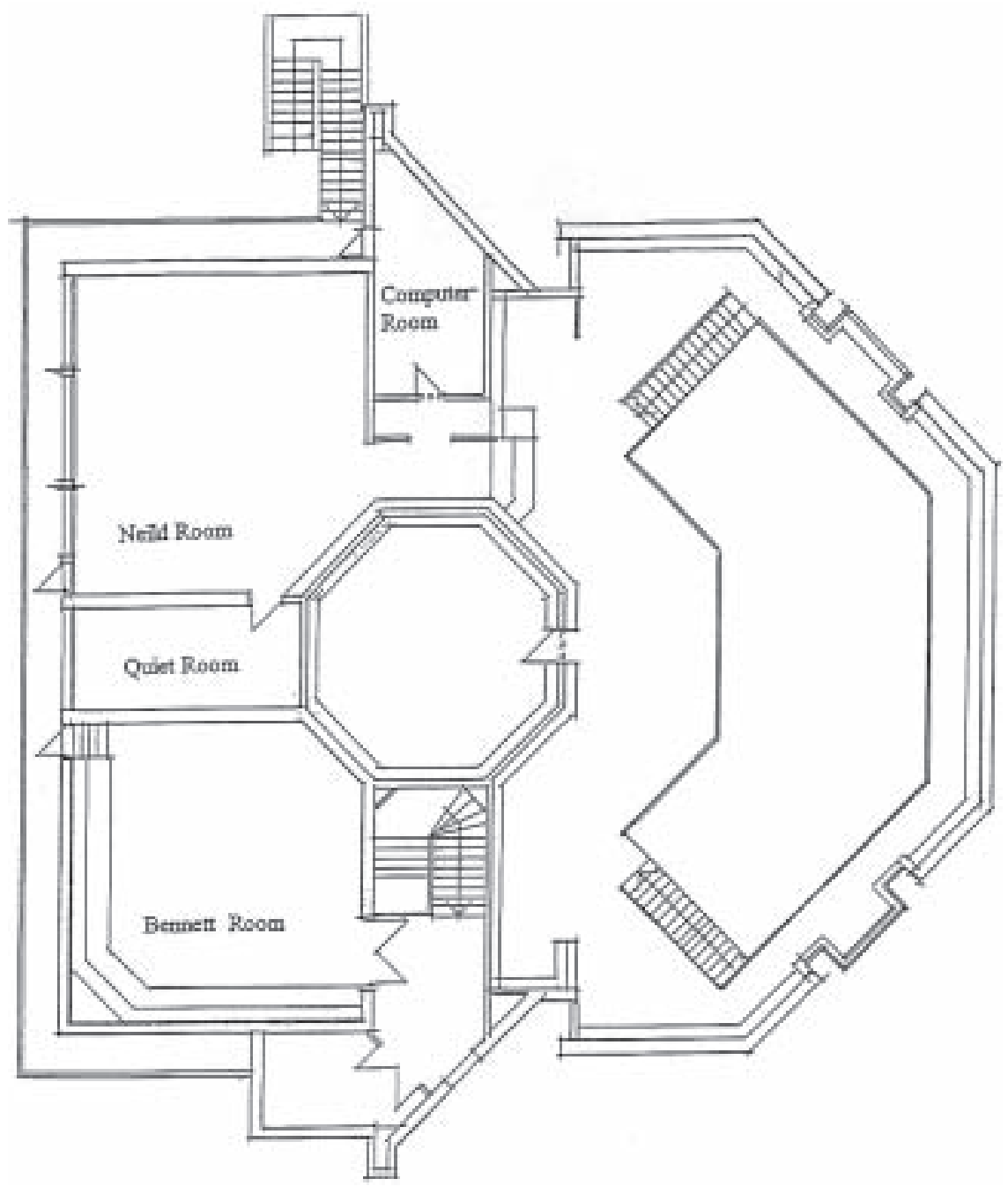

Clare College - Forbes Mellon Library

Upper floor ground plan

Arup Associates - Architects, Engineers and Quantity Surveyors 

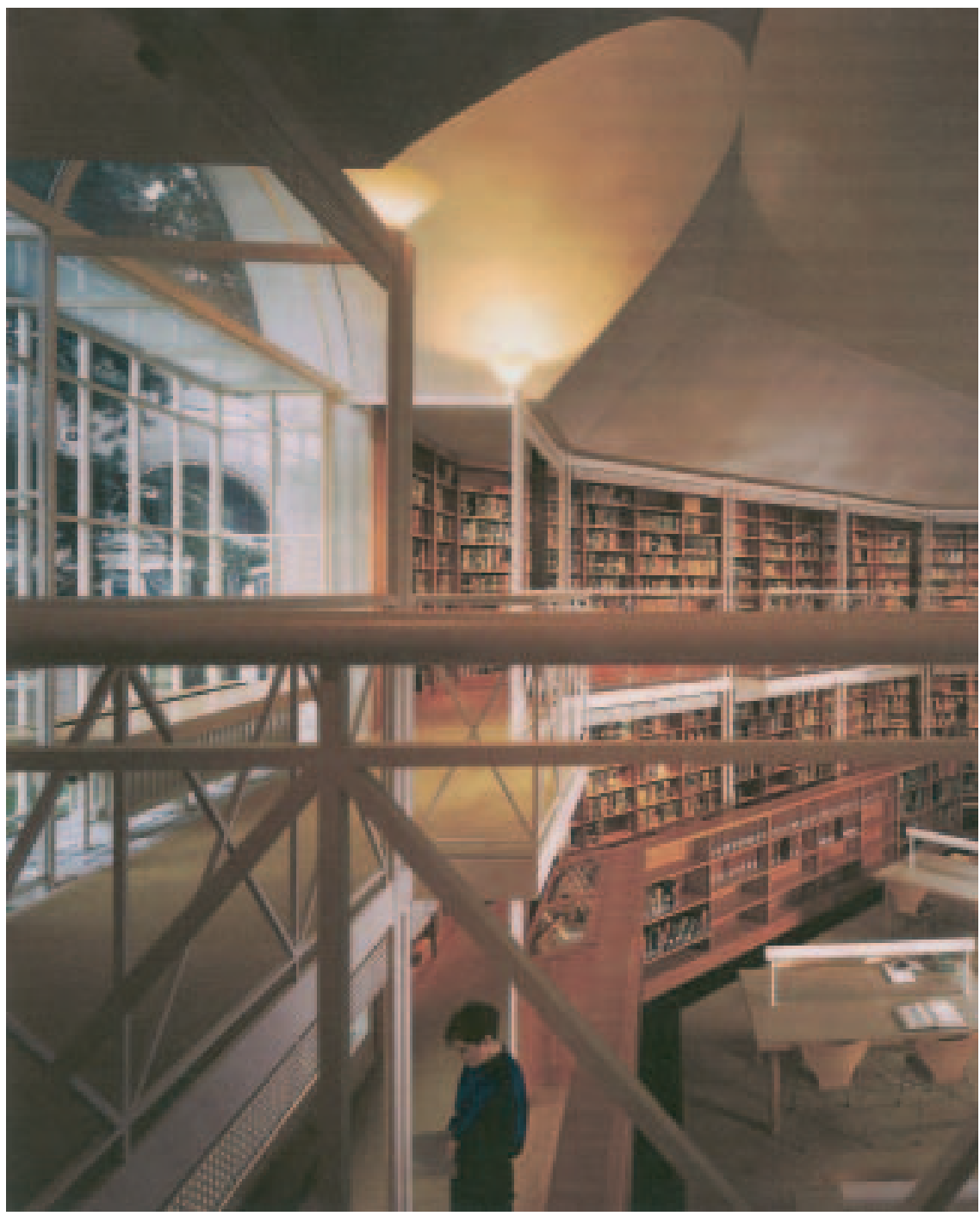

Clare College - Forbes Mellon Library Interior view of library

Arup Associates - Architects, Engineers and Quantity Surveyors 


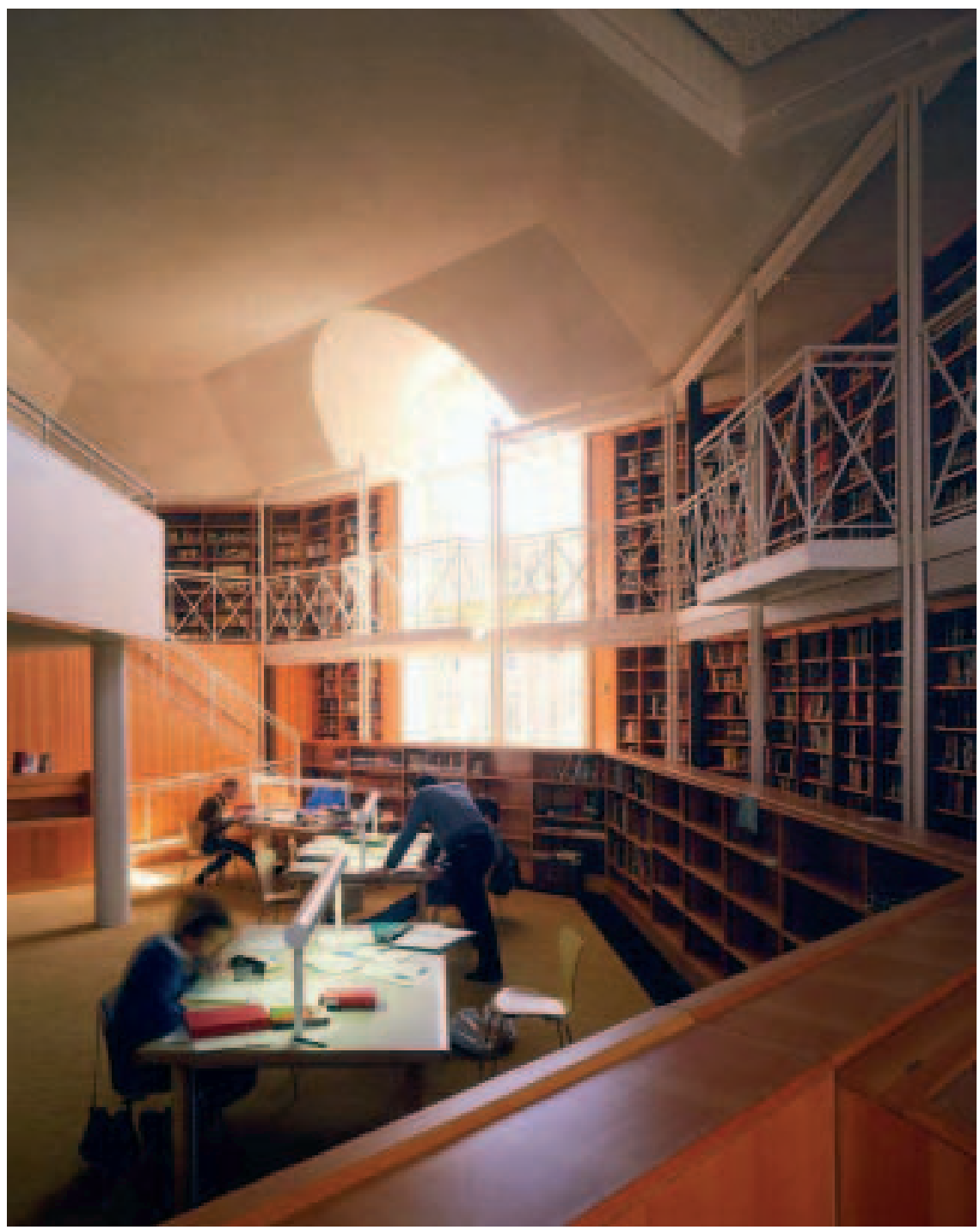

Clare College - Forbes Mellon Library Interior view of library

Arup Associates - Architects, Engineers and Quantity Surveyors 
Girton College Library and Archive 


\section{A GENERAL INFORMATION ABOUT THE LIBRARY}

a) Name and address

1. A library in the higher education sector. A constituent college of Cambridge University

2. Girton College Library

3. Girton College, Huntingdon Road, Cambridge CB3 OJG, United Kingdom

4. Phone: $+44(0) 1223338970$

Fax: $\quad+44(0) 1223339890$

E-mail: library@girton.cam.ac.uk

5. Frances Gandy

6. Frances Gandy

b) Population served

7. 800

8. 700

9. 4

10. 200

c) Conditions of the library (before the new project)

11. approximately $420 \mathrm{sq} \mathrm{m}$

12. formerly 104 (now 148)

16. 4.6

17. 91 hours per week in Full Term

40 hours per week at other times

Open 293 days per annum

\section{B THE NEW BUILDING: AIMS AND FEATURES}

\section{a) Architect(s)}

18. Allies and Morrison, 85 Southwark Street, London SE1 OHX

19. Helena Thomas and Nicholas Champkins

20. Extension: yes

Renovation: yes 


\section{b) Aims of the new building}

21. The new library, archive and special collections building houses the College's remarkable collection of papers and rare books which derives from its pioneering role in the history of women's higher education. The new building provides generous and environmentally-stable storage space for the Archive and Special Collections, alongside a reading room and facilities for staff and visitors to access and research the material. Rooms and facilities for conservation are included, together with new offices for library staff, an IT resources area for users of the library and all its collections, additional study spaces, a meeting room, a new reference area, cloakroom facilities and disabled access. The building is conceived as an integral and complementary extension to the present library facilities.

The brief established by the College for the new building called for a design that would avoid dependence on air conditioning and would instead ensure a stable environment for both the Archive and the Special Collections through the configuration and construction of the building itself. The idea of generating an architecture out of the practicalities of servicing elements in this way seems particularly appropriate at Girton, as Alfred Waterhouse (the original Girton College architect) pioneered such an approach, most notably in his great ventilation chimneys at the Natural History Museum in London.

\section{c) Special Features}

22. The new extension to the existing library buildings forms an integral centre for the academic resources of the College on its main site. In establishing the preferred site for the new building, attention was paid not only to the organisational requirements, but also to the history and growth of the College as a whole. The original College buildings, designed by three generations of the Waterhouse family, have evolved over six separate phases of construction to form a collegiate structure of buildings arranged around a sequence of linked courts. The main public rooms within the College, including the Chapel and Library, project out into the landscape and away from the rectangular enclosures of the courts. The new archive building is positioned to form the fourth side of a courtyard already implied by the existing buildings.

23. The new archive/special collections building takes the form of a single storage area, containing the combined archive and special collections stores, with a 
central reading room adjacent. The Littler reading room is located the intersection of the archive and a new IT suite forming an extension to the existing library. This second wing reinforces the creation of the courtyard and ensures that the library and Duke building share a common entrance. Crucially this also allows a visual connection through to the mature parkland landscape setting for the college.

The solution that has been developed for the archive is a building that consists of two discrete parts. The first is an inner box, highly insulated, air tight, and heavily constructed with dense masonry walls and a concrete floor and roof. This enclosure contributes thermal mass and moisture absorption to assist with controlling variations in temperature and relative humidity. In addition this inner box is detailed and constructed in excess of building regulations with regards to air permeability assuring the stability of the internal environment. ${ }^{1}$ The second outer layer is separated from the inner box and comprises a brick screen wall to the external elevations and an elegant lead pitched roof. Together these elements act not only as an 'umbrella' but also as a 'parasol' protecting the inner container from extreme variations in temperature and dissipating their effect.

This reflects current professional opinion in archive management, and is also desirable in terms of the environment, the control of future running costs, and minimising the risks associated with the failure of equipment.

The design of the new building is sympathetic to the existing library and chapel, not only in terms of its organisation but also in form and appearance. The front elevation is conceived as a brick garden wall structure punctuated by the asymmetrically located and dramatic main reading room window shaded by terracotta panels. These finely detailed panels, reflecting the gothic tracery beyond, are supported within a suspended metal work frame. This is held off the ground to allow uninterrupted view when seated from the reading room and IT suite beyond giving depth at the focal point of the elevation.

The use of terracotta and red brick recognizes the fine architectural context that is both robust and relatively simply configured. The language is continued by a series of fine lines drawn by terracotta 'fins' inserted at

1 The building has an air permeability rate of $0.83 \mathrm{~m}^{3} / \mathrm{hr} / \mathrm{m}^{2}$ @ 50pa. Good practice is below $10 \mathrm{~m}^{3} / \mathrm{hr} / \mathrm{m}^{2} @$ @ 50pa. 
regular intervals, and a chamfered incision reveals views through to the existing buildings and the richly planted perimeter of the herringbone brick paved courtyard.

The library office spaces located to the north-east allow the full height glazing facing the courtyard to be seen at its best. The office spaces are now housed within three quarter height screens that respond to the rhythm of the existing library buttresses and offer a sense of transparency. The existing external brickwork of the Hyphen link becomes an internal wall of exposed brickwork, allowing a clear distinction between the existing and the new and forming a new small courtyard.

The pitched roof of the new archive building is faced in four stepped layers of lead. The library link building is, by contrast, a simple, flat-roofed lightweight timber and steel structure, covered with a roofscape of sedum planting. As well as offering benefits in terms of thermal insulation, this covering has the benefit of contributing to the view of landscaped areas from the windows of the existing upper library.

While the details of the new building and its spatial organisation are clearly modern, the proposed design establishes specific relationships with the other college buildings. For example, the arrangement of the columns and openings in the library link building, whose height is suppressed below the parapet of the Hyphen, follows precisely the bay structure of the existing library, and the lower eaves height of the new archive building relates to the parapet level of the Hyphen Link.

\section{TECHNICAL INFORMATION ABOUT THE NEW BUILDING}

\section{a) Floor area (in sq metres) for questions 24 to 33}

\section{4. $400 \mathrm{sq} \mathrm{m}$}

25. Littler Reading Room (12 study spaces for researchers); Entrance area with information desk; Reference area

27. IT Resources area offers 21 computers and 3 additional computer-free study spaces

28. Archival collections and Special collections housed in an environmentallycontrolled repository

29. Meeting room with seating for 6

30. Small exhibition space introduced in new glazed link to display archival 
material. (Examples from Special Collections already on display in existing library)

33. New offices for Librarians, Archivist, Library staff; preparation and conservation rooms $(x 3)$, including one for the Book Conservator

34. Environmentally-controlled repository containing mobile, rolling stacks for the archive and special collections

35. Entrance foyer, cloakrooms/w.c.s, conservation/preparation rooms x 3; (lift to first floor in existing library)

36. New building is on one level only. Original library is on two levels

37. 148

39. 21

40. 6

41. 121

\section{b) Total potential capacity of shelving (linear metres or volumes)}

44. New building has $2,000 \mathrm{~m}$ of mobile shelving, which can be double stacked - either back to front with books, or top to bottom with archive boxes

48. $4.6+$ casuals in Full Term

\section{c) Mechanical features}

49. The environmental conditions in the conservation areas are largely dictated by the requirements of BS5454 (2000); "the temperature should be at a fixed point, between $16 \operatorname{deg} C$ and $19 \operatorname{deg} C$ with a tolerance of $1 \mathrm{deg} C$ on either side, but ranging neither below the minimum nor above the maximum". In practice this gives a maximum temperature of $19 \operatorname{deg} C$ and, in order to achieve this safe maximum, a room set-point temperature of 18 $\operatorname{deg}$ C.

Although it is relatively straightforward to maintain this temperature in winter (by heating the rooms), in summer, when outside temperatures frequently exceed this figure, this type of application normally requires closecontrol air-conditioning utilising mechanical refrigeration. Mechanical refrigeration consumes significant amounts of energy as it is powered by electricity instead of gas.

An alternative approach to cooling these spaces is to use thermal mass to store "coolth" during the summer nights, when the outside air temperatures are below the $18 \mathrm{deg}$ C, and recover this "coolth" during the following days. It is already common practice to make archive buildings as thermally 
massive as possible by using exposed concrete soffits, plastered masonry walls making the windows small or non-existent. This is an effective way of stabilising space temperature swings, but there is a limit to how much "coolth" the fabric of the building can store - the limit being the requirement (of BS 5454) that the room temperature must not drop more than a degree below room set-point. In practice this means a night cooling strategy running the ventilation plant with "full fresh air" setting during the summer nights - can only be allowed to operate until the room temperature drops to $17 \mathrm{deg} C$. This requirement acts as a natural limit on the amount of "coolth" the building fabric can usefully store.

In the new Archive and Special Collections Wing at Girton College, a way around this problem has been prototyped, which stores "coolth" outside the fabric of the building by means of buried ducts. These ducts can be sub-cooled to well below the minimum room temperature and therefore store more "coolth". The installed system uses plastic ducts running beneath the courtyard to feed Air Handling Units serving the Archive Store and Reading Room. The ventilation plant also incorporates filtration, humidification and a refrigeration-based cooling system.

The buried ducts were calculated to reduce the energy required for cooling the fresh air to the archive store from $195 \mathrm{KWh}$ per year to $89 \mathrm{KWh}-\mathrm{a}$ reduction of $54 \%$.

The reduction in heating energy (as the buried ducts pre-heat the air in winter as much as they pre-cool it in summer) is from $2272 \mathrm{KWh}$ to 1752 $\mathrm{KWh}$, or around $23 \%$.

What makes these figures particularly significant for archive buildings is the fact that the fresh air heating and cooling demands in an archive represent a much greater proportion of the overall heating and cooling load than would be the case in say an office or library. An archive typically has small windows (or none) and very good insulation, thus the heat lost through the building envelope by conduction becomes less significant than the heat required to treat the fresh air used for ventilation. In the Archive and Special Collections Store at Girton College, the conduction heat losses were calculated to be $1035 \mathrm{KWh}$; i.e. less than half the fresh air heating requirement! In an office or library one would expect the reverse to be the case.

50. see above at 49

52. The acoustic strategy developed for the building is the use of acoustic plaster 
for key areas of the ceiling and high level wall surfaces. This is supplemented by functional acoustic pinboard for offices or meeting areas. This gives an acoustically good environment for study without being sterile.

53. Book lift in old library

55. 3M security gates to prevent book theft; full intruder alarm system throughout

57. Cat $5 e$

\section{SCHEDULE OF THE BUILDING PROCESS}

59. 2000-2002

62. July 2003

63. 18 months

64. 2 months

65. April 2005

\section{E COSTS}

70. Contract value $f 1.6$ million

Project cost $f 2.5$ million

\section{AWARDS}

The Archive Centre has been given a 2006 Royal Institute of British Archives (RIBA) Award. 


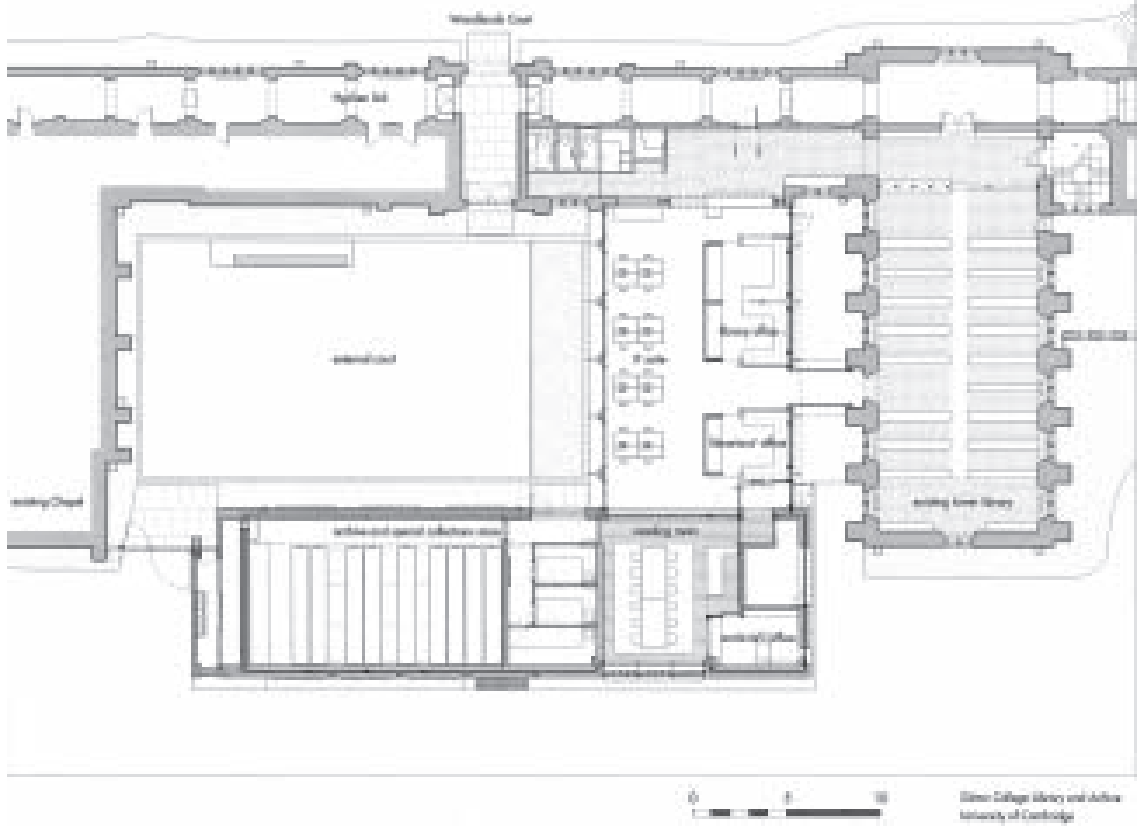

Girton College Library and Archive, Ground plan 

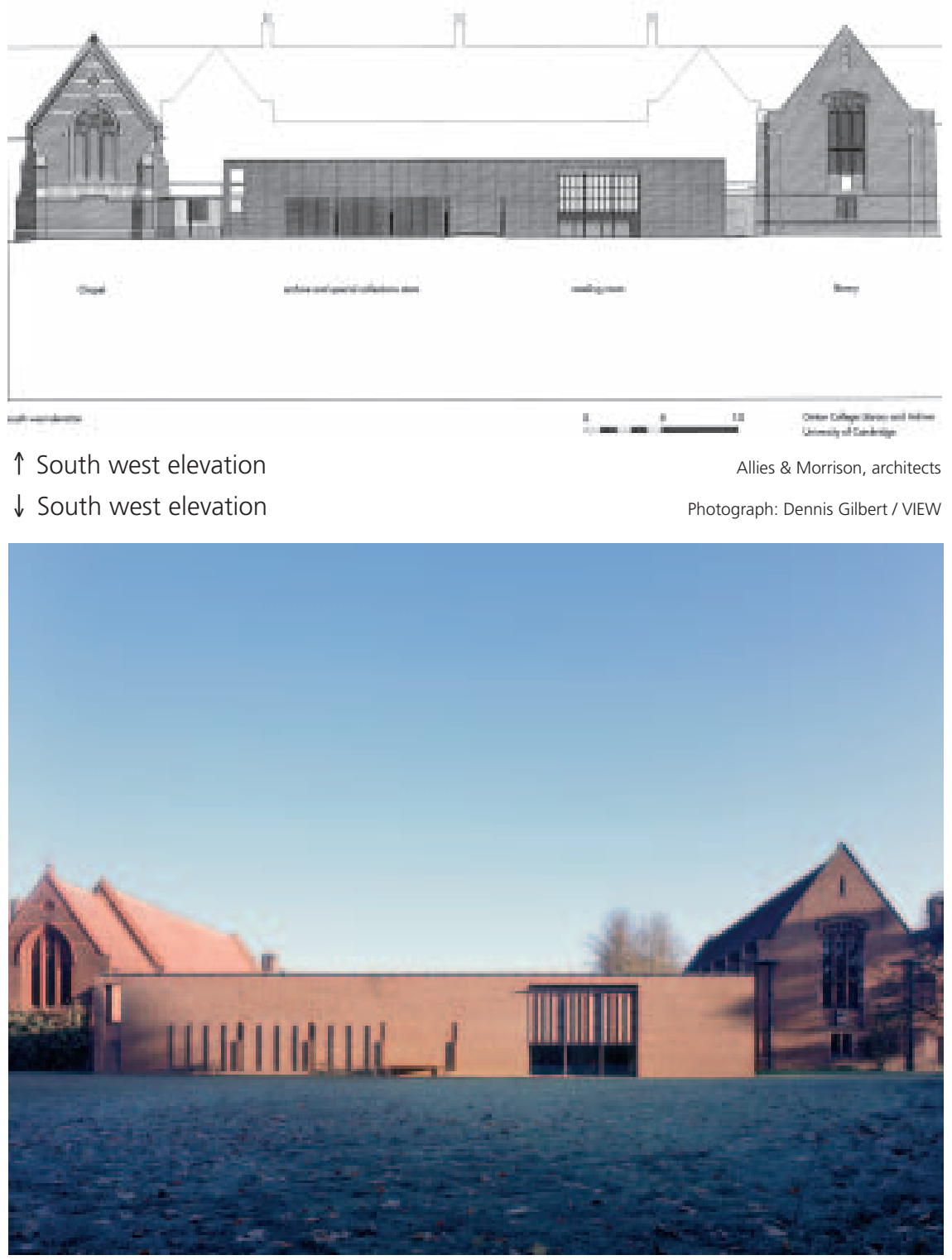


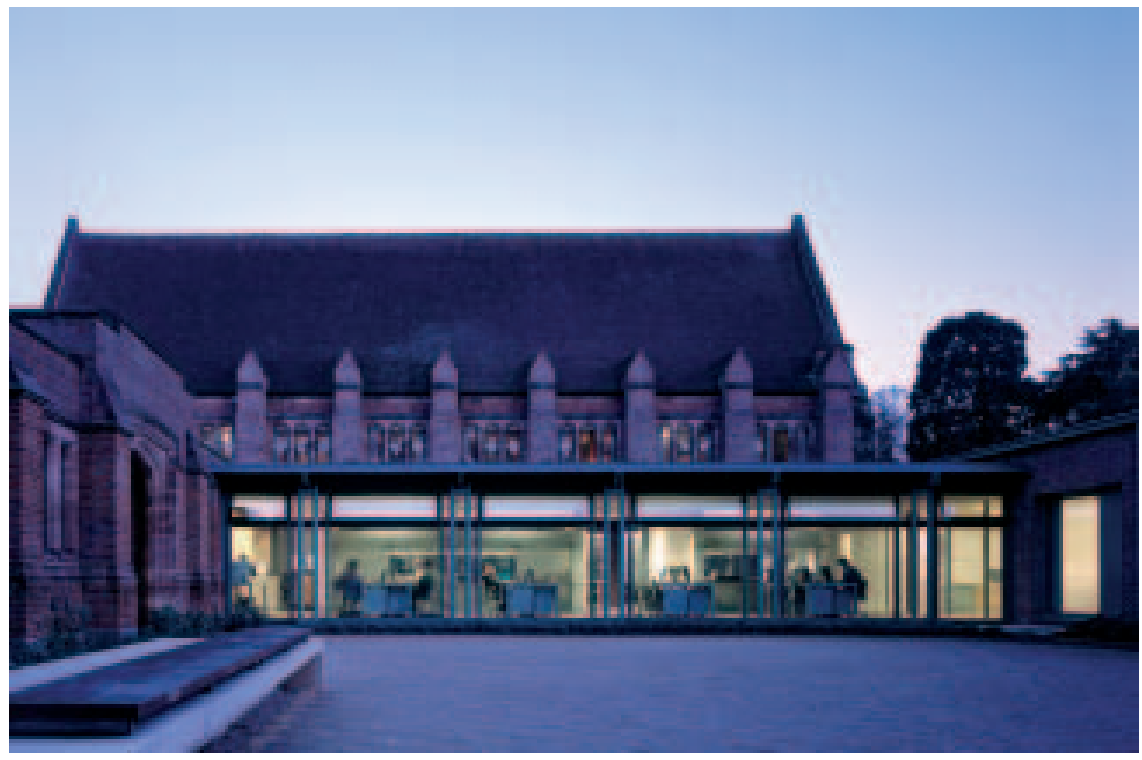

Girton College Library and Archive, IT suite

Photographs: Dennis Gilbert / VIEW

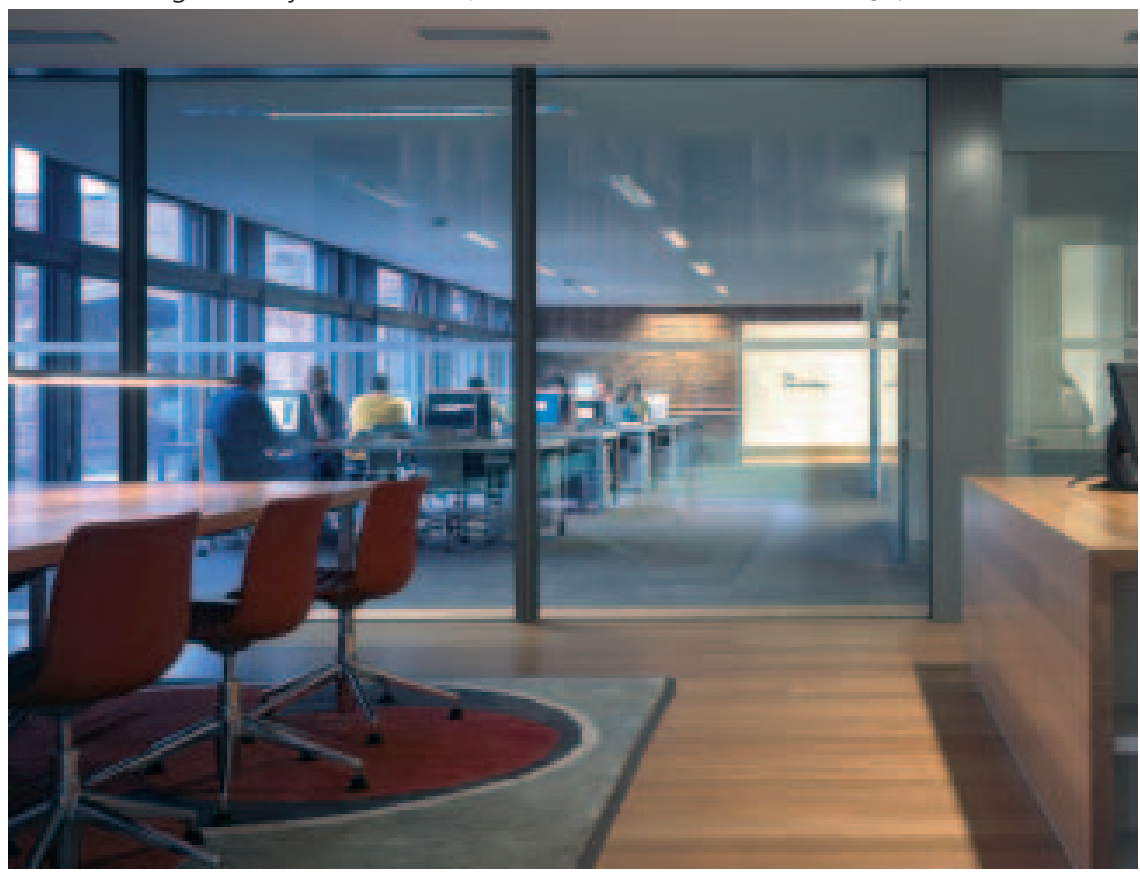




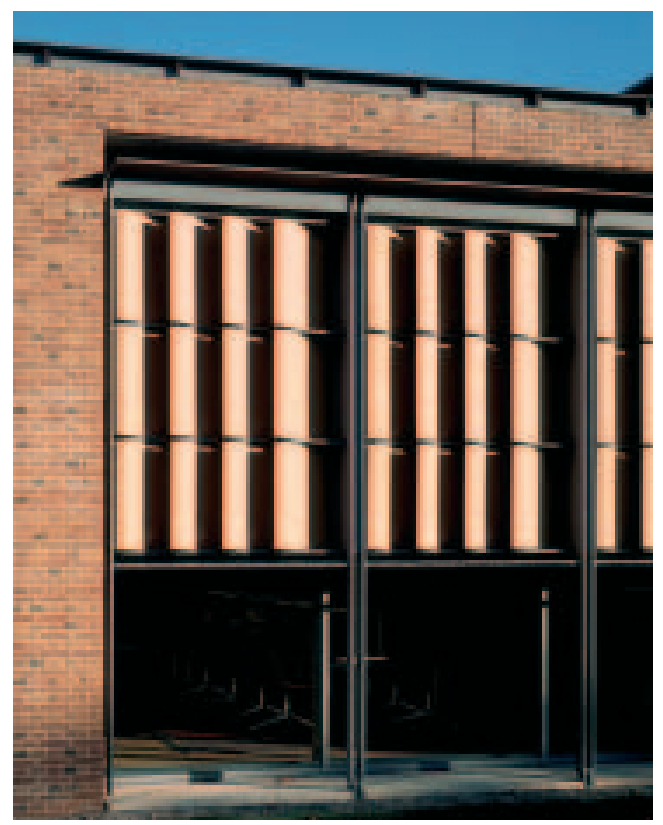

Girton College Library and Archive

Archive and special collections' reading room

Photographs: Dennis Gilbert / VIEW

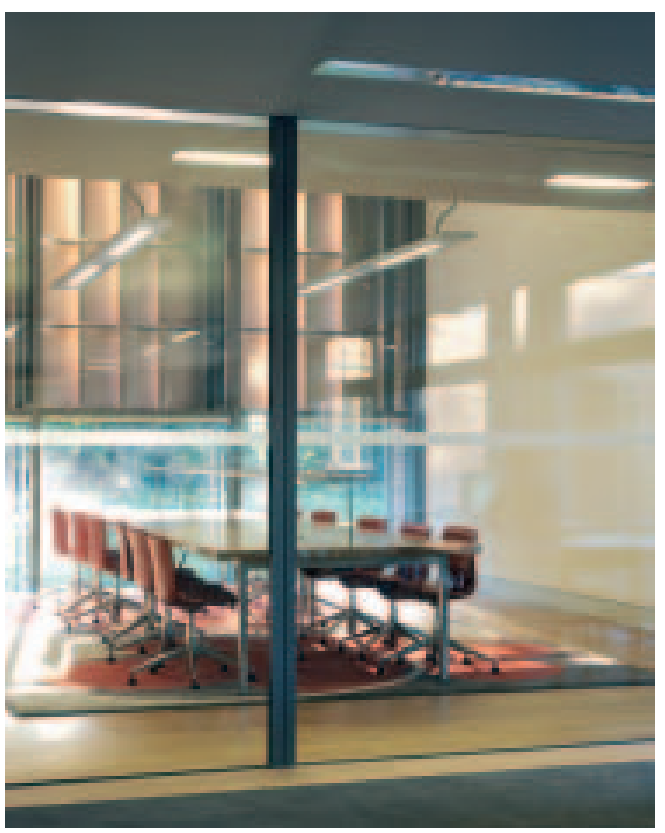


Gonville and Caius College Library 


\section{A GENERAL INFORMATION ABOUT THE LIBRARY}

a) Name and address

1. Academic, College

2. Gonville and Caius College Library

3. Cambridge CB2 1TA

4. Phone: 01223332419

Fax: 01223332430

E-mail: library@cai.cam.ac.uk

5. David Abulafia

6. Mark Statham

b) Population served

7. 850

8. 550

9. 200

10. 100

c) Conditions of the library (before the new project)

13. 65000

16. 3.5

\section{B THE NEW BUILDING: AIMS AND FEATURES}

\section{a) Architect(s)}

18. Donald Insall Associates, Architects

19. Mark Wilikinson

20. Renovation: yes

b) Aims of the new building

21. To transfer the College library into a renovated building previously housing the Squire Law Library

- More holdings in open stacks

- More readers seats, networked 


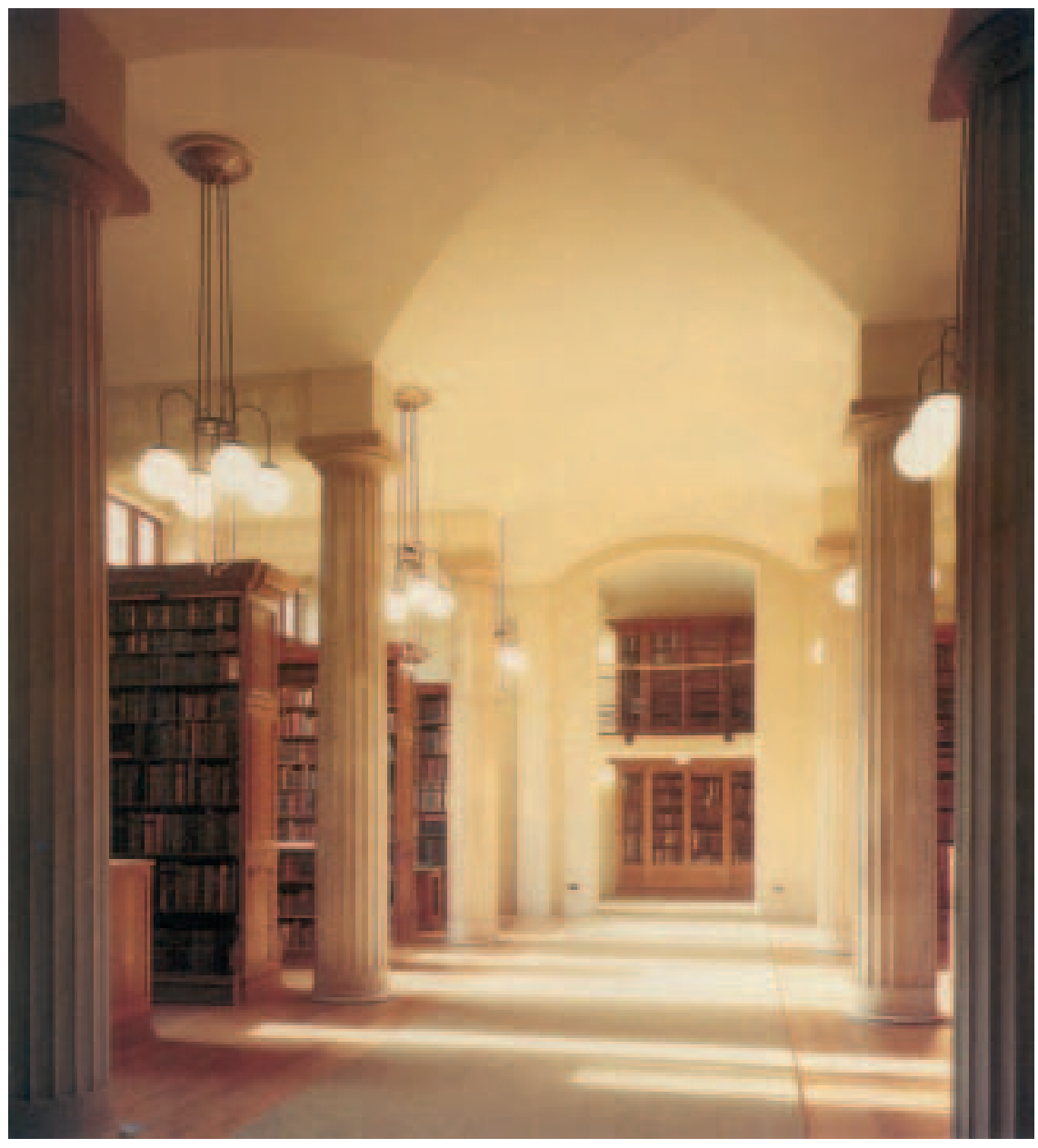

Gonville and Caius College Library, Lower library 
- Development of the library in the field of research, better conditions for research on special collections or archives. Space for visiting scholars.

- Computer and audiovisual materials, computer room in basement.

Extensive repairs and refurbishment were undertaken, access and circulation improved, while every effort was made to restore the clarity of Cockerell's original spatial concept in the plan. Computer and security systems, new heating and electrical services were also introduced.

\section{c) Special Features}

22. The library is separated from the main college by a footpath. Aims of relocation were more space and a quieter ambience.

23. A grand rectangular building in the neo-classical style designed by C.R. Cockerell in 1836-37, it housed part of the University Library until 1934 and then the Squire (Law) and Seeley (History) libraries. The building is entered through a great arch and the ground floor is a simple groin-vaulted space. The first floor is double height with galleries on each side and pairs of free-standing lonic columns at each end. The barrel-vaulted ceiling has diagonal coffering and is decorated. The bookcases are arranged in generous bays.

Disabled access is now provided.

\section{TECHNICAL INFORMATION ABOUT THE NEW BUILDING}

\section{a) Floor area (in sq metres) for questions 24 to 33}

25. yes

27. yes

28. yes

33. yes

34. yes

35. yes

36. 4 levels: the Working library and its gallery, special collections and archives, and computing resources.

37. 150

39. 30

41. 120 


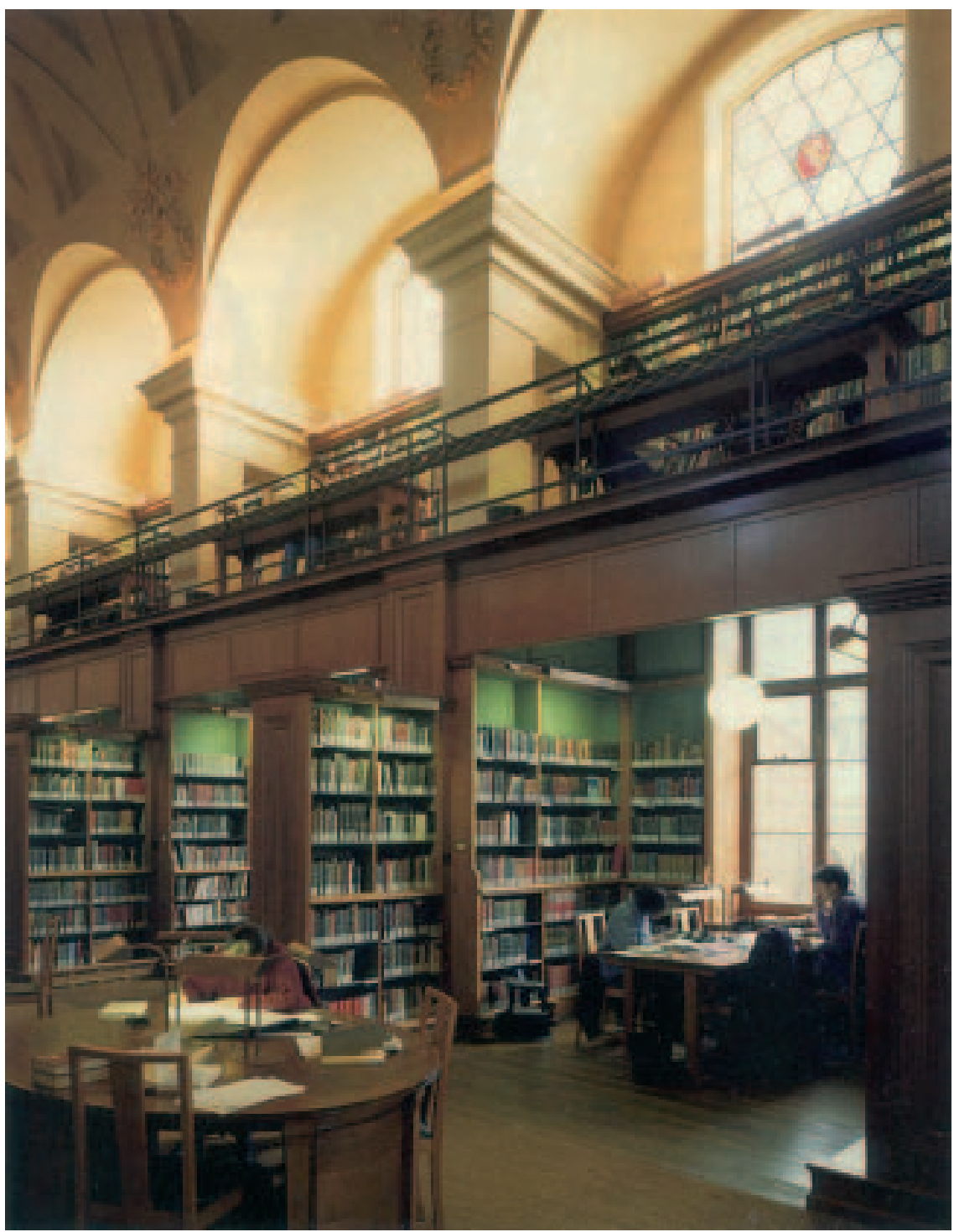

Gonville and Caius College Library, Upper library 
b) Total potential capacity of shelving (linear metres or volumes)

42. 90000

43. 60000

$44 .+45.5000$

47. 25000

48. 7

c) Mechanical features

50. New heating system with radiators

51. Vaulted ceiling newly illuminated. Some specially made hanging light fittings on the ground floor based on a 1930s design. Desk lights.

53. Lifts

54. yes

55. CCTV

56. yes

58. The contemporary stained glass has been fully cleaned and repaired. The college's $17^{\text {th }}$ century bookcases have been installed on the ground floor.

\section{SCHEDULE OF THE BUILDING PROCESS}

62. 1995-1996

63. 1 year

64. 1996-1997

65. 1997 (official opening)

\section{F PUBLICATIONS:}

Prynne, J.H.: Caius and Cockerell : the transformation of a library, Cambridge: Gonville and Caius College 1997. 


\section{Jesus College -}

\section{Quincentenary Library}




\section{A GENERAL INFORMATION ABOUT THE LIBRARY}

a) Name and address

1. Academic library

2. Quincentenary Library

3. Jesus College

Cambridge, CB5 8BL

United Kingdom

4. Phone: 01223339451

Fax: 01223324910

E-mail: quincentenary-library@jesus.cam.ac.uk

5. Quincentenary Librarian, Rhona Watson

6. Rhona Watson

b) Population served

7. 888

8. 767

9. 9

10. 115

c) Conditions of the library (before the new project)

11. 8 rooms

12. 50 reader seats

13. $900 \mathrm{~m}$

14. $740 \mathrm{~m}$

15. $160 \mathrm{~m}$

16. 2

17. 8 am-midnight, 360 days/year

\section{B THE NEW BUILDING: AIMS AND FEATURES}

a) Architect(s)

18. Evans \& Shalev

2 Belsize Crescent

London. NW3 5QU 
19. Eldred Evans \& David Shalev

20. New building: yes

\section{b) Aims of the new building}

21. The brief called for a modern library to replace the existing war memorial and law libraries together with a new computing centre. It was to be designed in harmony with the historic setting of the college and to create an intimate atmosphere for reading among the books.

\section{c) Special Features}

22. The new library has been built within the grounds of a 500 year old college. Some of the buildings date back to the $12^{\text {th }}$ century Benedictine nunnery of St Mary and St Radegund. It is part of a new court which includes an accommodation building designed by the same architects. The buildings are set within landscaped grounds.

23. The building provides a magnificent variety of working spaces flooded with daylight and naturally ventilated: a beautiful, calm and stimulating environment for study and reflection.

The building also houses various works of art including an Anthony Gormley statue and a stained glass window designed by Graham Jones (and made by John Reyntiens).

The external walls are made of $50 \mathrm{~mm}$ light honey coloured facing bricks and the roof of Welsh slate. The inside contains white-stained American ash, cream French limestone, bespoke furniture and a lavender coloured carpet.

The entrance hall leads to a large rotunda with views through to the stained glass window in the Garden Room and up the main staircase that leads to the middle floor and the Gormley statue. The ground floor also contains the librarian's office, the closed stack area, the computer centre and a separate law library. The law library reuses the shelving and inscriptions from the old War Memorial Library.

The middle floor of the library has carrels overlooking the staircase and several bays containing both books and tables. There are 2 large rooms that may be used for seminars or meetings.

The top floor may be reached either by means of the lift or the spiral staircase. There is a barrel-vaulted ceiling and an open gallery overlooking the middle 
floor. There is also a disabled toilet next to the lift.

Almost every wall in the library is lined with shelves. There are a variety of different seats and types of reading spaces, from several small private study rooms to the open gallery stools and some comfortable easy chairs. There is a large amount of natural light and there are views from most areas to the gardens surrounding the building.

\section{TECHNICAL INFORMATION ABOUT THE NEW BUILDING}

\section{a) Floor area (in sq metres) for questions 24 to 33}

24. Gross floor area $=1417 \mathrm{sq} \mathrm{m}$

27. $76 \mathrm{sq} \mathrm{m}$

30. $3 \mathrm{sq} \mathrm{m}$

34. $63 \mathrm{sq} \mathrm{m}$

36. The library has three floors. Most of the areas are dual use, for example, areas with book shelves are also used for seminars or exhibitions.

37. 193 seats

39. 37

40. 36

41. 120

b) Total potential capacity of shelving (linear metres or volumes)

42. 55,000 volumes

48. 2.5 people

\section{c) Mechanical features}

49. The building is ventilated naturally, using openable windows and rooflight panes, only the separate computing room has air-conditioning.

50. The library has a gas central heating system. There is low-temperature hotwater heating via radiators, heat emitters and underfloor heating in the entrance area and garden room.

51. The library has a large amount of natural daylight helped by a large central rooflight running the whole length of the building. Many electric lights are turned off automatically by a photocell on bright days and the library has translucent electric blinds that can be operated by library users. 
52. The library is mainly open plan but there are several rooms which the users can use as 'quiet areas'. The Garden Room is a designated area where talking is allowed.

53. There is a 13-person hydraulic passenger lift serving all three floors.

55. There is a Plescon Security Products electromagnetic security system with 2 CCTV cameras.

56. A building management system monitors temperatures and opens roof panes automatically to encourage air flow.

57. The library uses Cat 5 twisted pair cabling and has 97 Cat5 points.

58. There is a 24 hour access control system to the library and it has a computerized self-service issue system.

\section{SCHEDULE OF THE BUILDING PROCESS}

60. 1991

62. September 1993

63. 26 months

64. November 1995

65. November 1995 (actual opening)

March 1996 (official opening)

\section{E COSTS}

68. $f 220,000$

70. $f 2,020,000$

\section{F PUBLICATIONS:}

- A house of books, in: Architects' Journal, 203 (1996), no. 16 (25. April), p. 29-37. (ISSN 0003-8466).

- Building for Jesus, in: Building Design, 2000, November 3, p. 20-25. (ISSN 0007-3423). 


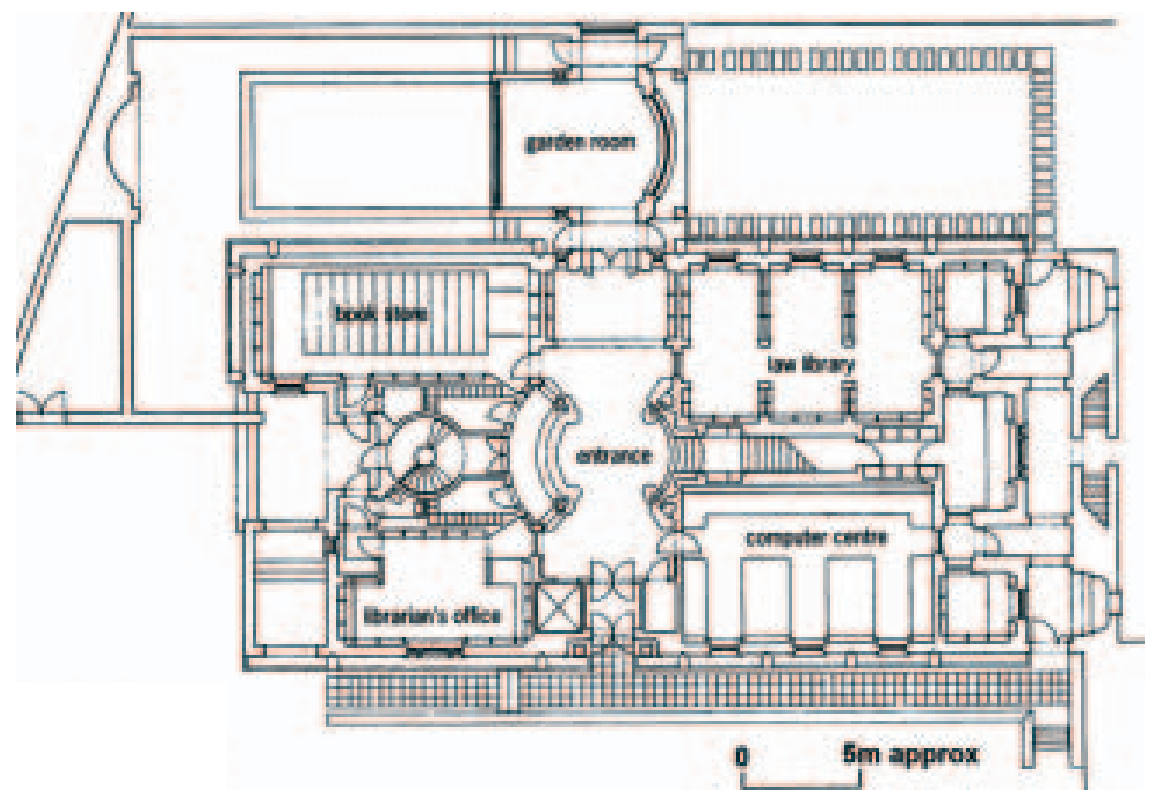

Jesus College - Quincentenary Library, Ground floor plan

Architects: Evans \& Shalev

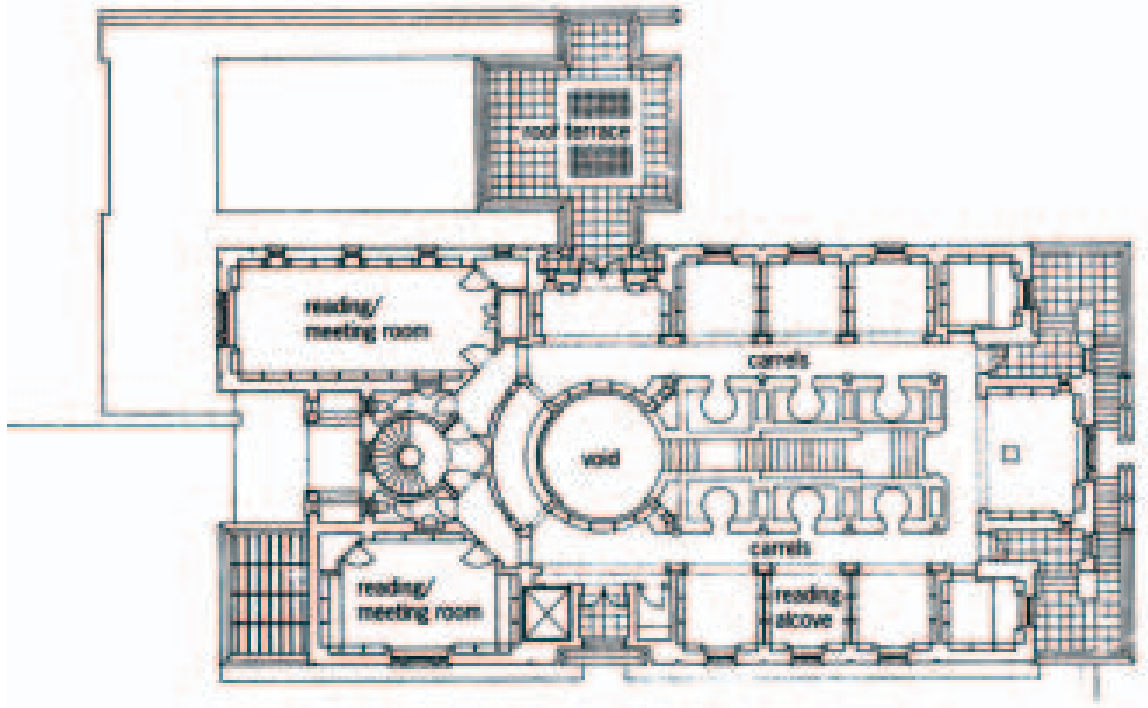

Jesus College - Quincentenary Library, First floor plan

Architects: Evans \& Shalev 


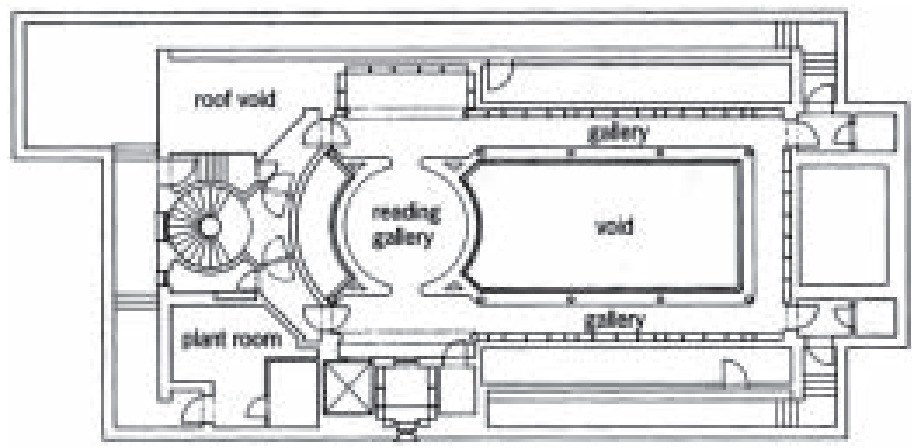

Jesus College - Quincentenary Library, Second floor plan

Architects: Evans \& Shalev

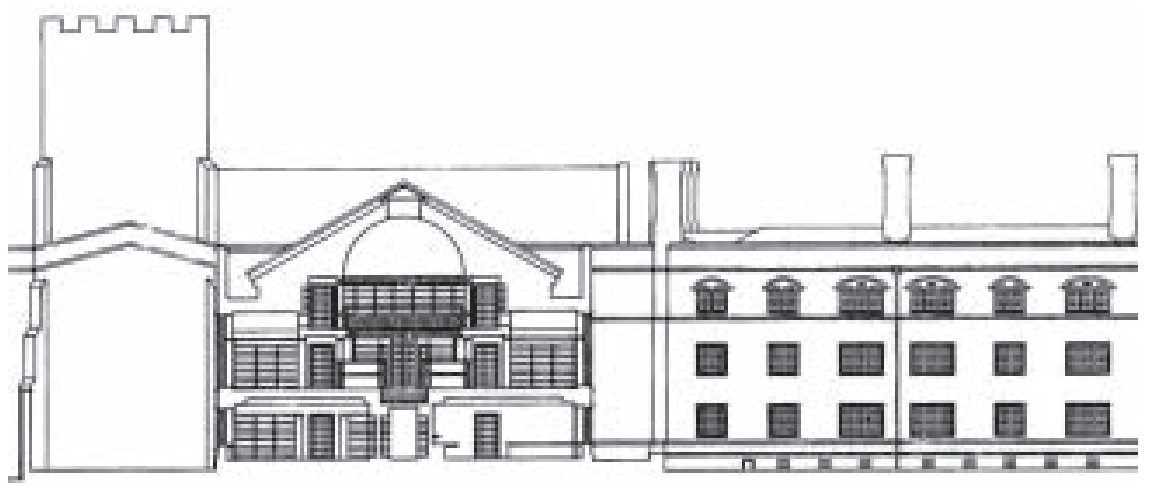

Jesus College - Quincentenary Library, Section Architects: Evans \& Shalev 


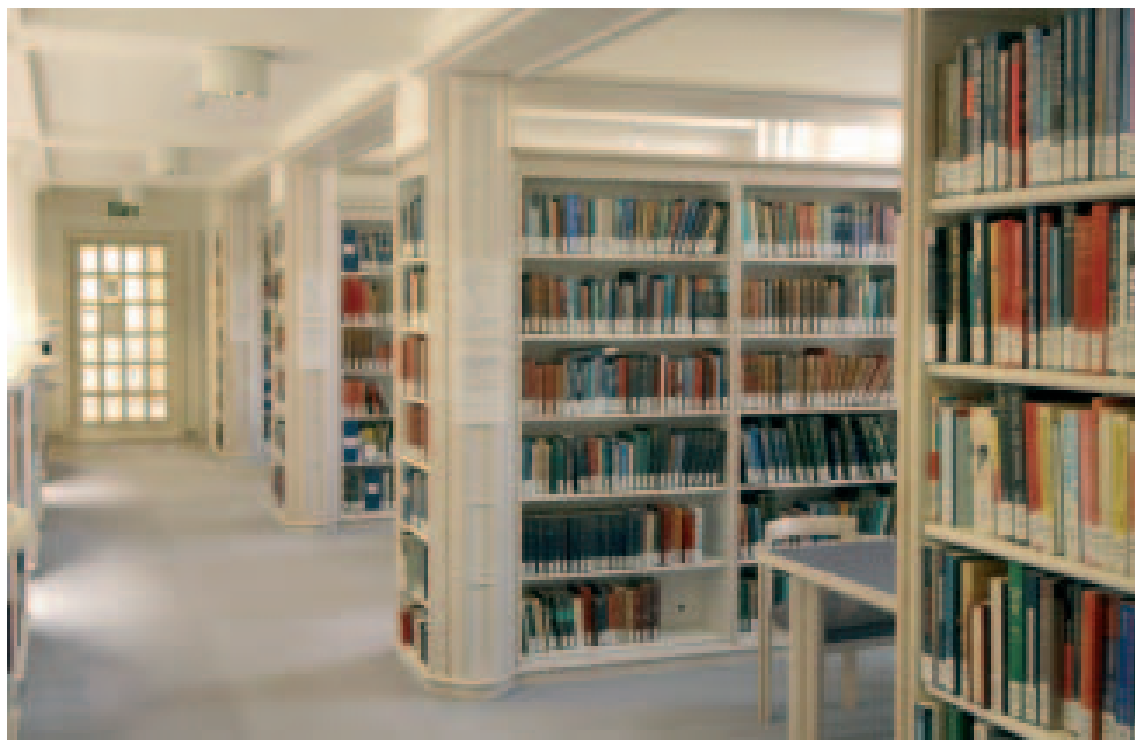

Jesus College - Quincentenary Library, First Floor Reading bays looking southwest

Photograph: Rhona Watson 


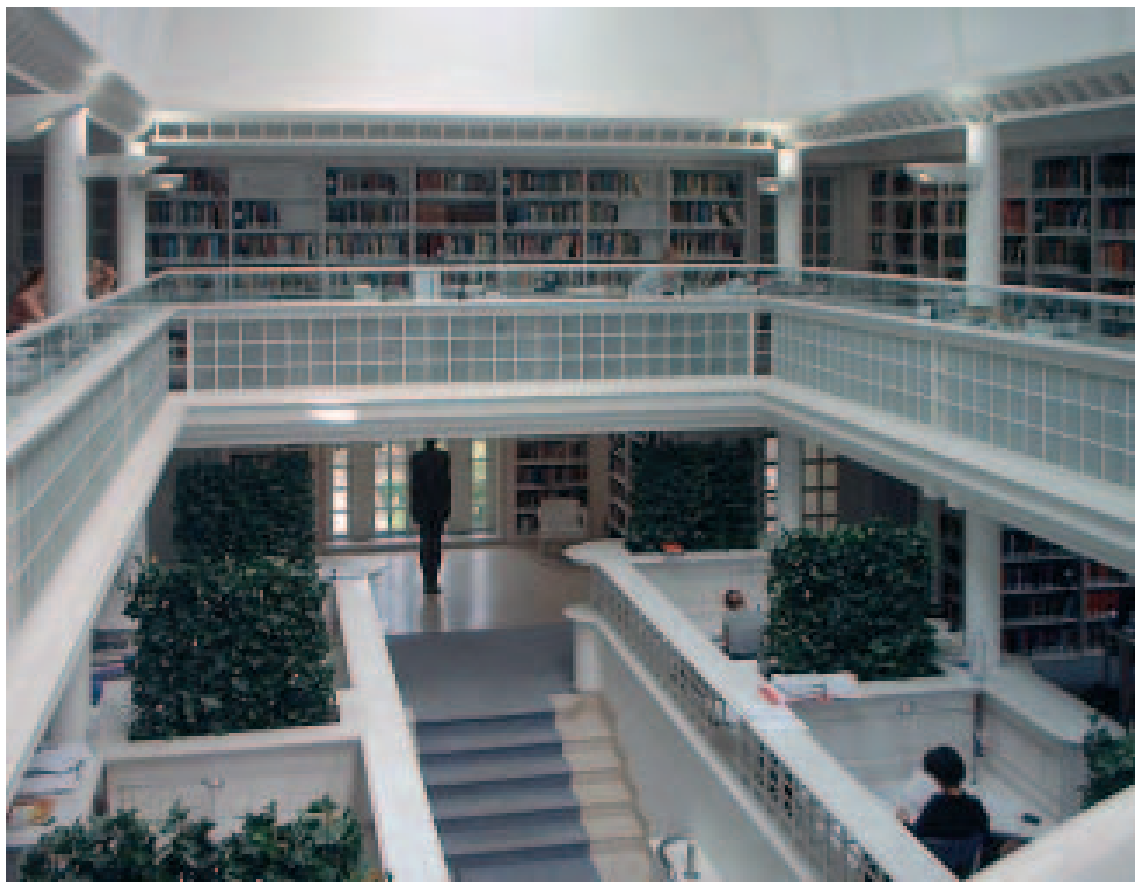

Jesus College - Quincentenary Library, Second Floor From reading gallery looking north showing main staircase and first floor carrels Photograph: Rhona Watson 


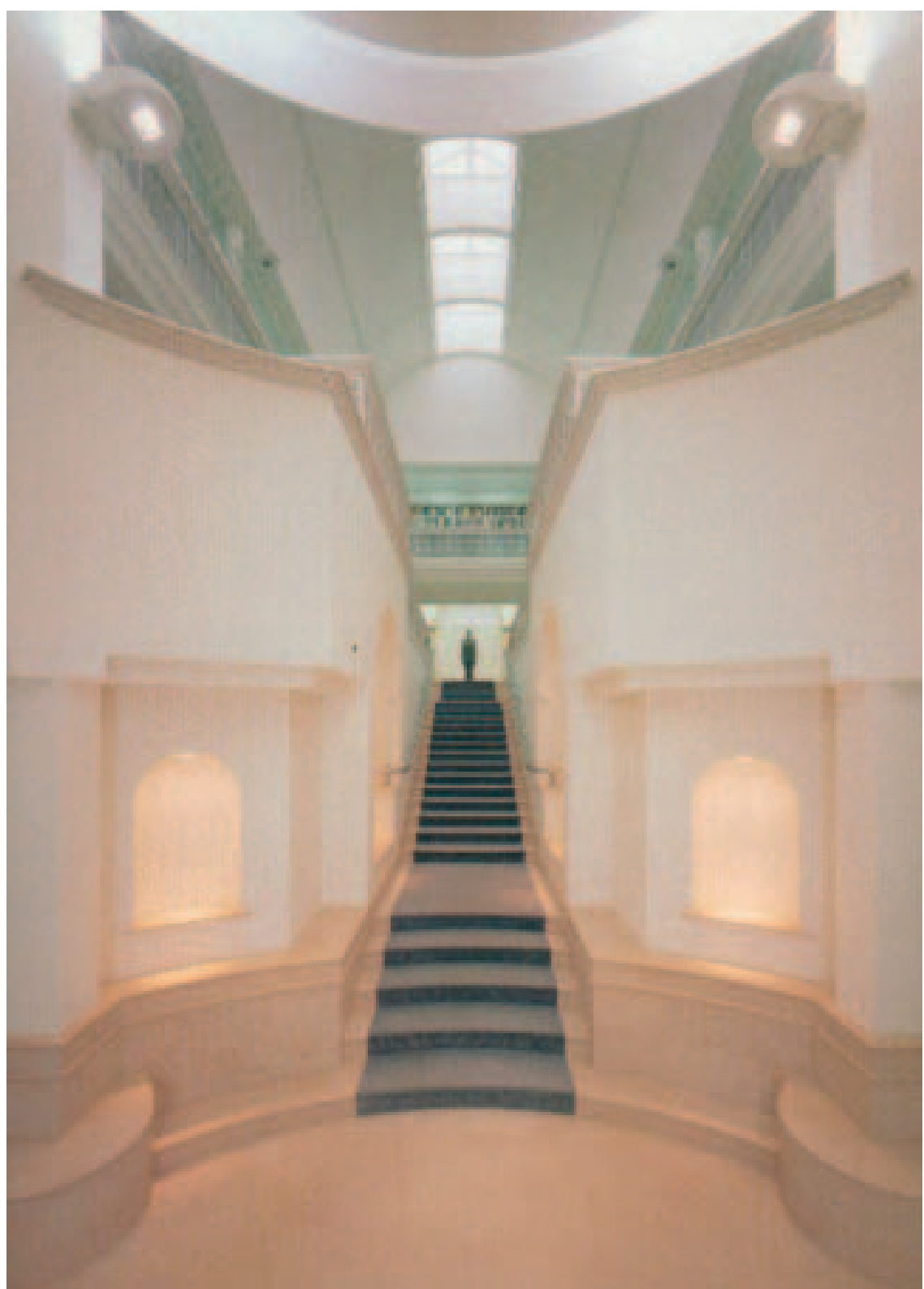

Jesus College - Quincentenary Library, Ground Floor 
Lucy Cavendish College Library 


\section{A GENERAL INFORMATION ABOUT THE LIBRARY}

a) Name and address

1. College Library

2. Lucy Cavendish College Library

3. Lady Margaret Road Cambridge, CB3 OBU

4. Phone: 01223332190

Fax: 01223332178

E-mail: library@lucy-cav.cam.ac.uk

6. Catherine Reid, Librarian

Karen Davies, Archivist

b) Population served

8. 231

9. 10

10. 47

c) Conditions of the library (before the new project)

12. 14

13. 21250 vols

16. $0.8 \mathrm{fte}$

17. $24 \mathrm{hrs} /$ day, 365 days

\section{B THE NEW BUILDING: AIMS AND FEATURES}

\section{a) Architect(s)}

18. Freeland Rees Roberts

19. Tristan Rees Roberts

20. New building: yes

b) Aims of the new building

21. To accommodate the needs of an expanding student body and also provide purpose-built computing and archive facilities.

More holdings in open stacks, more readers seats

Computer and audiovisual materials 


\section{c) Special Features}

22. Location of the library on a campus

23. Made of brick with smaller windows facing the busy road alongside it, and large windows overlooking the lawn used by students for recreation, the building is staggered in response to the row of mature trees which screen the building from the road. The entrance hall is double height so that the geography of the building is immediately obvious on entering it. Student reading areas are varied and range from individual carrels to large and small tables, all adjacent to book cases. The rare book collection and its reading areas can be closely controlled by the archivist. The building has disabled access.

\section{TECHNICAL INFORMATION ABOUT THE NEW BUILDING}

a) Floor area (in sq metres) for questions 24 to 33

24. $900 \mathrm{sq} \mathrm{m}$

36. 5

37. 93

38. 3

39. 15

40. 30

41. 45

b) Total potential capacity of shelving (linear metres or volumes)

42. 47000 vols.

43. 36000 vols.

44. 11000 vols.

45. 10000 vols.

47. Archive store room can hold $70 \mathrm{~m}$ of records

48. $4.1 \mathrm{fte}$ (total staff including Library, IT Support and Archive)

1.5 fte (library staff only)

\section{c) Mechanical features}

49. Via a centrally controlled air-management system

50. Centrally controlled

53. A single universal access lift serving all floor levels apart from the top floor. 
55. Use of CCTV surveillance equipment.

56. An automatic environmental monitoring system is in place measuring temperature and humidity.

\section{SCHEDULE OF THE BUILDING PROCESS}

59. July 1997

60. July-September 1997

62. August 1998

63. 14 months

64. September 1999

65. October 1999 


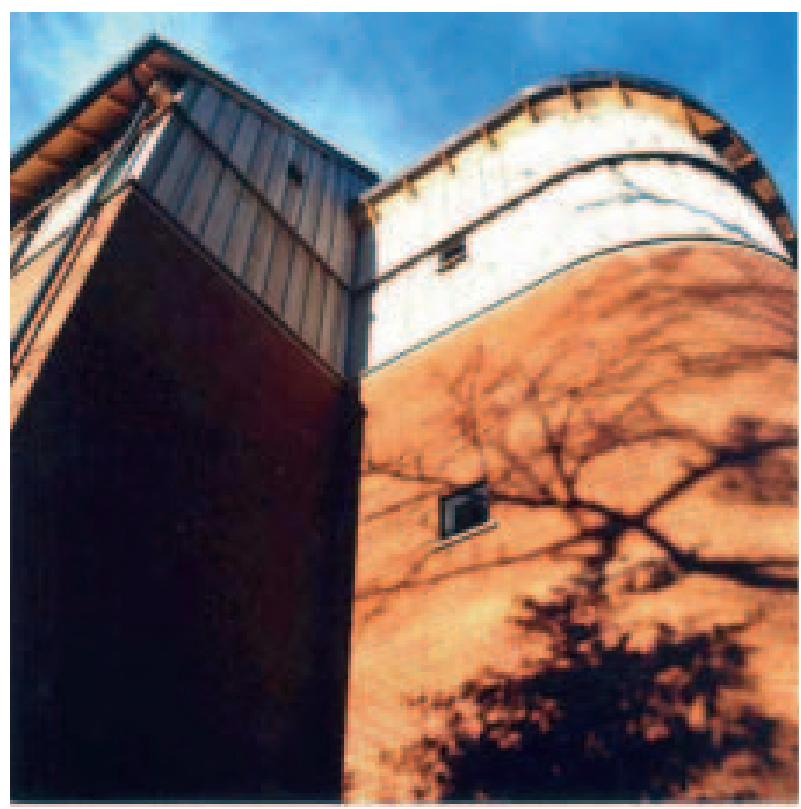

Lucy Cavendish College Library

East elevation (above)

External view at dusk (below)

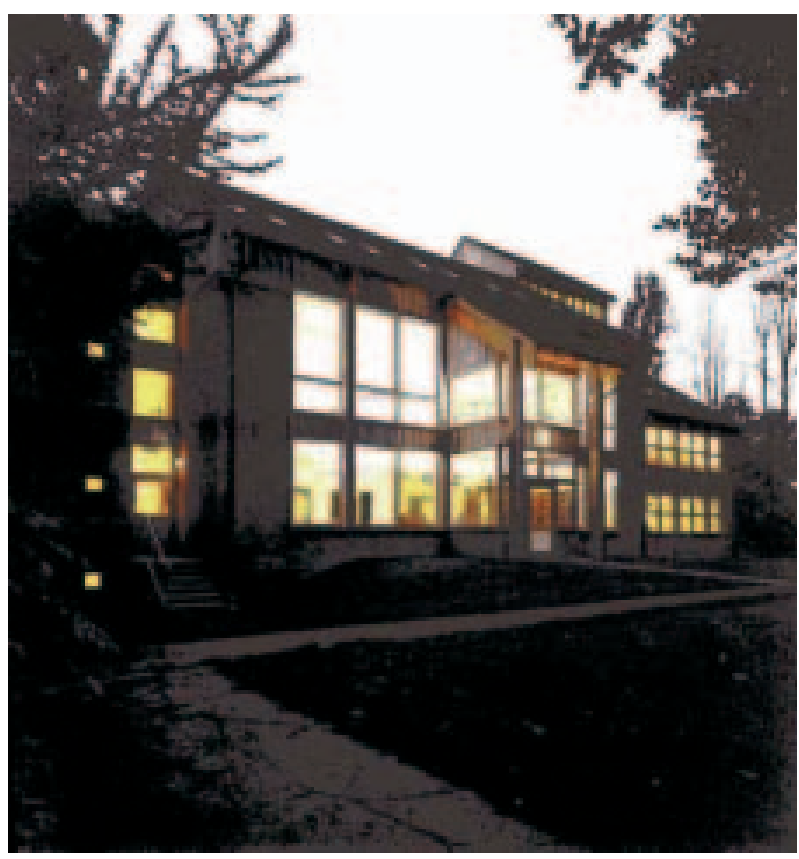




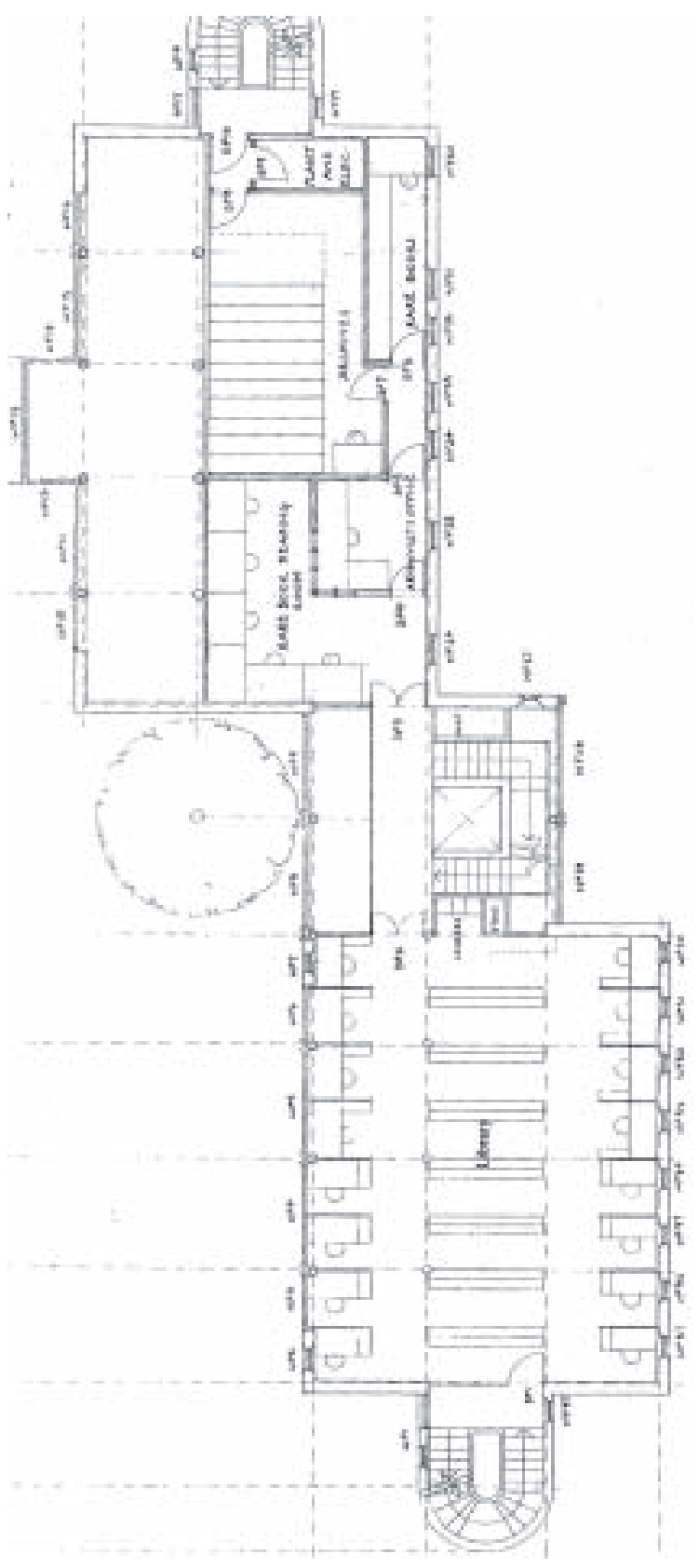

Lucy Cavendish College Library

First floor plan Freeland Rees Robert Architects 


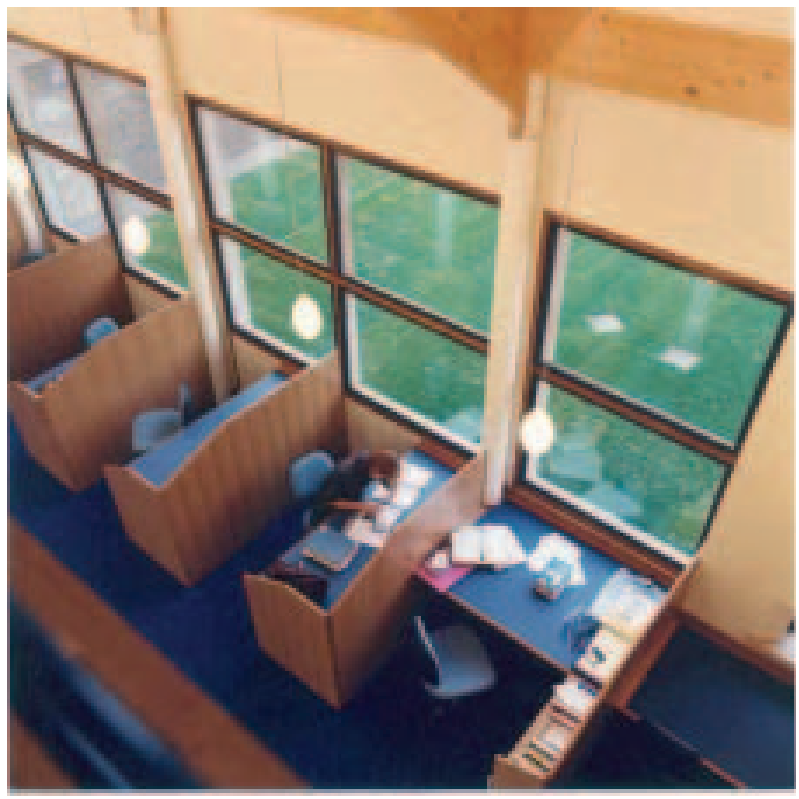

Lucy Cavendish College Library

First floor Reading room

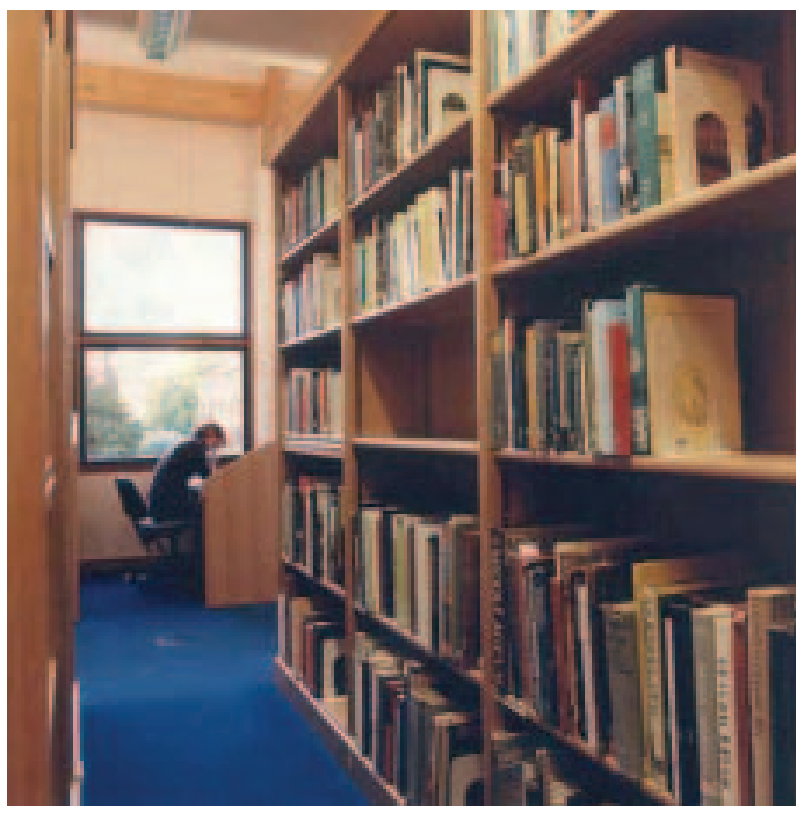



New Hall -

Rosemary Murray Library 


\section{A GENERAL INFORMATION ABOUT THE LIBRARY}

a) Name and address

1. College Library

2. Rosemary Murray Library

3. New Hall

University of Cambridge

Huntingdon Road

Cambridge, CB3 ODF

4. Phone: 01223762202

Fax: 01223763110

E-mail: library@newhall.cam.ac.uk

5. Ms Alison M. Wilson

6. Ms Alison M. Wilson

b) Population served

7. 530

8. 460

9. 8

10. 51 Fellows

c) Conditions of the library (before the new project)

11. $515 \mathrm{sq} \mathrm{m}$

12. 62

13. 45,000 vols.

14. 38,000

15. 7,000

16. 2.7

17. 168 hours per week 360 days per year

B THE NEW BUILDING: AIMS AND FEATURES

There have been 3 phases of development, see 21 below.

\section{a) Architect(s)}

18. 1) No architect. Managed in-house. 
2) R.H. Partnership

94 Chesterton Road

Cambridge

3) As above

19. 2) and 3) David Emond

20. Extension: yes

Renovation: yes

\section{b) Aims of the new building}

21. Three phases of development

1) Conversion of the Library basement from its previous (temporary) use as accommodation, to provide both open and closed stacks, more reader seats including comfortable armchairs, space for OPACs, toilets and an office.

2) Conversion of two guest rooms and a corridor to provide an information resource centre.

3) Renovation of the building after a structural failure to the roof

\section{c) Special Features}

22. Part of the original Grade 2* listed building (1964), the Library is one of the main components of the original college, forming one side of a central sunken courtyard.

The semi-basement was originally designed as space for a stack, but when it eventually reverted to the Library other needs were identified, in particular a larger office for staff, suitably placed for enquiries. The main entrance was changed to this level to serve both the IT resource centre and library.

23. 1. In the semi-basement the internal layout on the side overlooking the courtyard is the same as on the main floor above, with reading desks alternating with book bays. On the other side the closed stacks, toilets and office are partially underground and have little natural light. The noisiest area - enquiries, computers, photocopying - is by the entrance.

2. The space occupied by adjoining guest rooms was reconfigured to provide three bays for computers and a server room.

3. The roof has new external stainless steel post-tensioning, insulation and external drainpipes. Inside it has a new acoustic lining. A fire detection system and a new lighting scheme have been installed. 


\section{TECHNICAL INFORMATION ABOUT THE NEW BUILDING}

a) Floor area (in sq metres) for questions 24 to 33

24. $1,000 \mathrm{sq} \mathrm{m}$

25. $789 \mathrm{sq} \mathrm{m}$

27. $96 \mathrm{sq} \mathrm{m}$

28. Archives: $12 \mathrm{sq} \mathrm{m}$

33. $20 \mathrm{sq} \mathrm{m}$

34. $37 \mathrm{sq} \mathrm{m}$

35. $47 \mathrm{sq} \mathrm{m}$

36. The Library is now on 4 levels: 2 main floors and 2 galleries

37. 110

39. 23

41. 87

b) Total potential capacity of shelving (linear metres or volumes)

42. 65,000

43. 59,000

44. 6,000

46. 260 videos, DVDs and CD-ROMs

48. No extra staff employed

c) Mechanical features

49. Air Conditioning in the Resource Centre and Server Room only

50. Existing underfloor electric heating

51. Fluorescent ceiling lights; wall lights; desk lights to match 1960s fittings

52. Acoustic material on ceiling

54. Book lift

55. Card access system (Chubb)

57. Cat 5 UTP with RJ45 outlets

\section{SCHEDULE OF THE BUILDING PROCESS}

62. 1) June 1995

2) June 2001

3) June 2002

63. 1) 7 months

2) 4 months

3) 16 months 
64. Coterminous with final weeks of building

65. 1) February 1996

2) October 2001

3) October 2003

\section{E COSTS}

66. Existing site

67. 1) $f \quad 30,000$

2) $f \quad 173,000$

68. 1) $\mathrm{f} \quad 12,000$

2) $f \quad 25,000$

70. 1) $f \quad 42,000$

2) $f \quad 198,000$

3) $f 1,259,000$

\section{F PUBLICATIONS:}

Emond, David: New Hall refurbishment, in: Cambridge Architecture, 51 (2005), Winter/Spring, p. 4-5. 


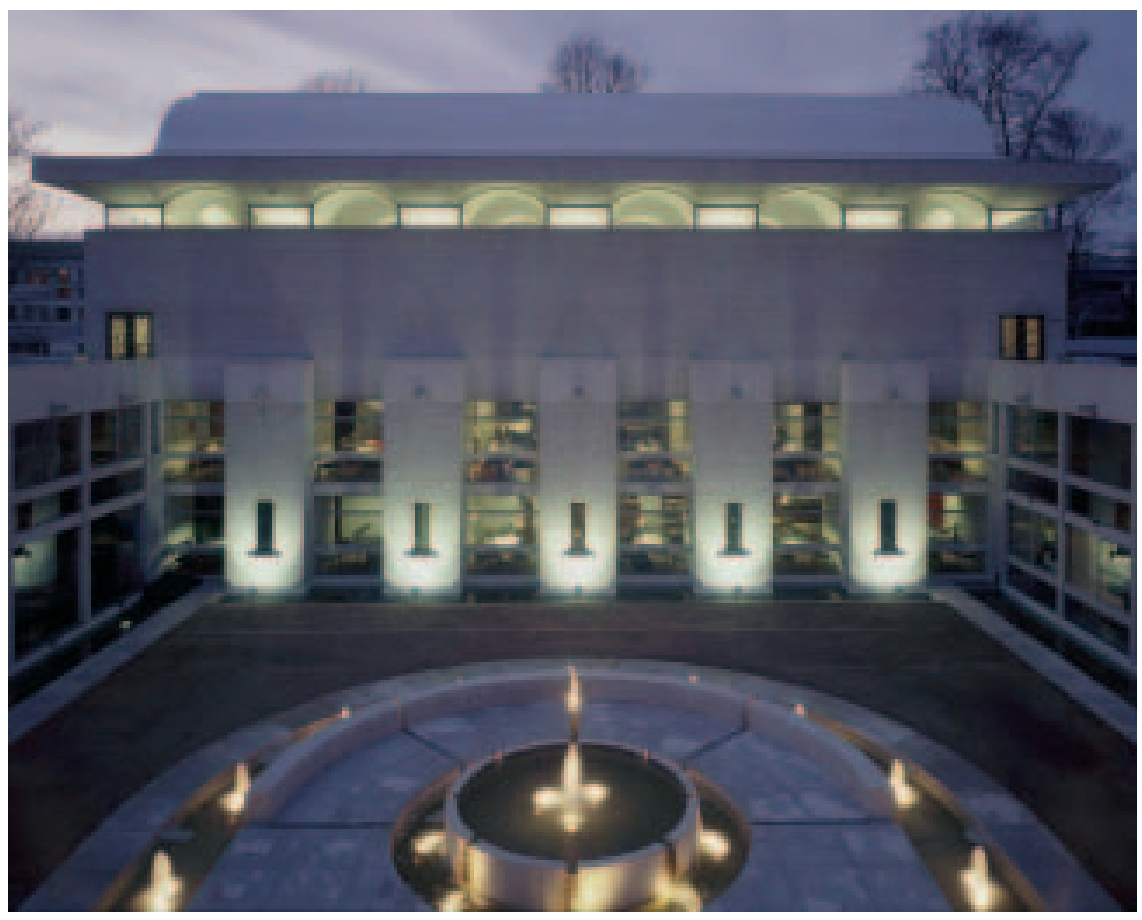

New Hall - Rosemary Murray Library Library and fountains 


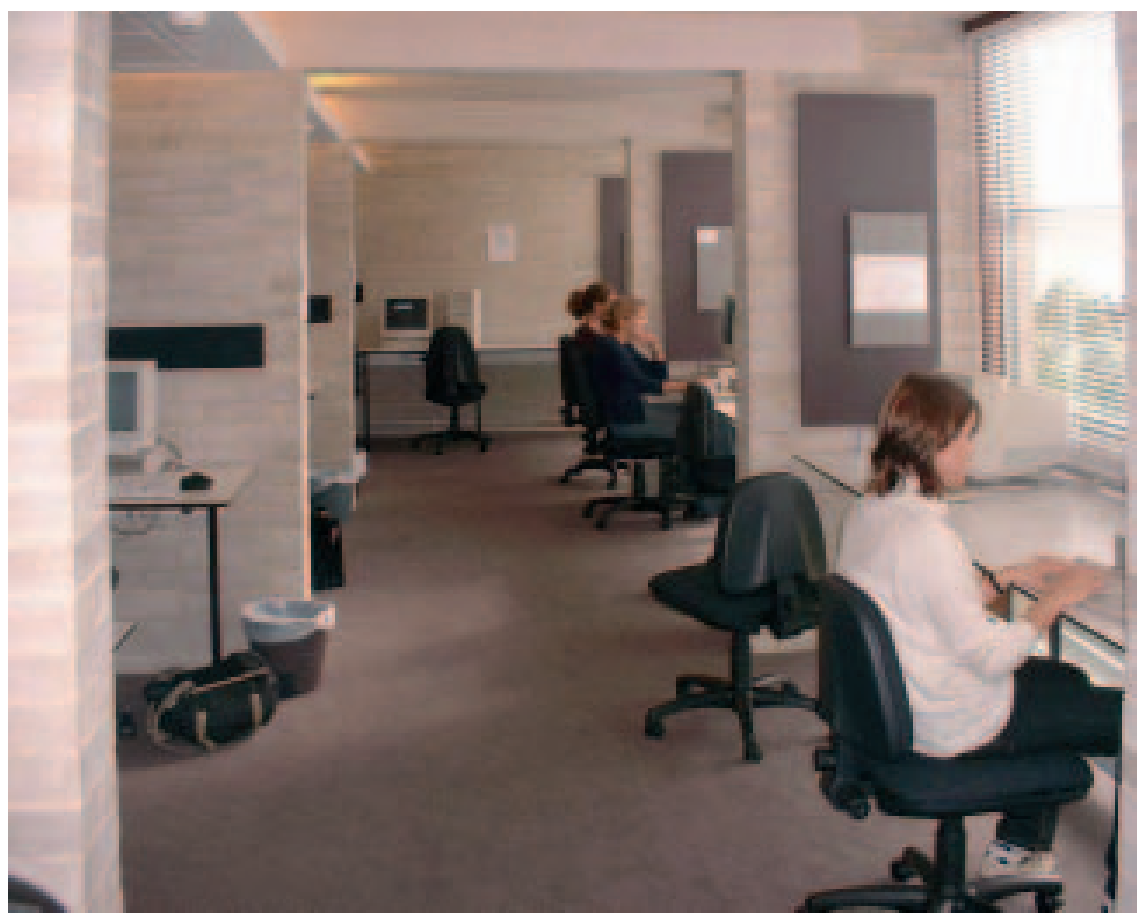

New Hall - Rosemary Murray Library

Computer room 


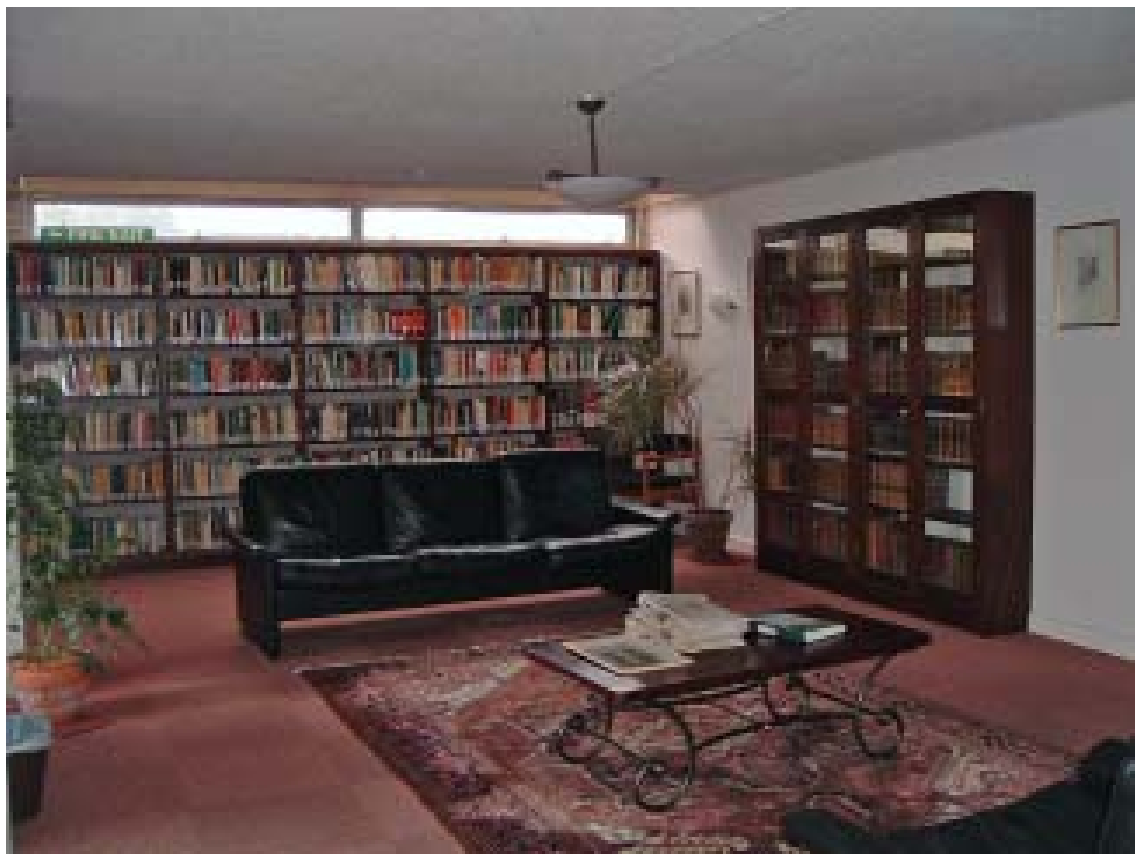

New Hall - Rosemary Murray Library

Rawson area 
Newnham College Library 


\section{A GENERAL INFORMATION ABOUT THE LIBRARY}

a) Name and address

1. Academic library, particularly supporting study at undergraduate level

2. Newnham College Library

3. Newnham College Library

Newnham College

Cambridge CB3 9DF

United Kingdom

4. Phone: +44 1223335740

E-mail: librarian@newn.cam.ac.uk

5. Librarian, Ms Deborah Hodder

6. Ms Deborah Hodder

b) Population served

7. 705 registered readers + visiting scholars, day visitors etc.

8. 578

9. 7

10. 120

c) Conditions of the library (before the new project)

11. 1,207 sq $\mathrm{m}$ (approximate estimate of total library area before the project)

12. 51

13. $3,089 \mathrm{~m}$ (approximately)

14. 2,429 m (approximately)

15. $660 \mathrm{~m}$ (approximately)

16. 3.4

17. 119 hours per week, 355 days per year (resident members)

35 hours per week 250 days per year (non-resident library users)

\section{B THE NEW BUILDING: AIMS AND FEATURES}

\section{a) Architect(s)}

18. John Miller and Partners

19. Richard Brearley

20. Extension: yes 


\section{b) Aims of the new building}

21. To provide increased accommodation for working library books, readers and information technology. To also provide improved and enhanced accommodation for the College Archives and for the Skilliter Centre for Ottoman Studies.

\section{c) Special Features}

22. Adjacent to, and connecting with, existing library buildings on the site of a former library extension (built in the 1960s and now demolished)

23. The new building reflects the existing character of the College's architecture in its scale and materials, and makes extensive use of natural light. It is on a rectangular plan, using axes and cross-axes to link with existing library and other college buildings. The main part of the building has twin barrel vaults; at the east end of the building, these are replaced by a single vault placed centrally. The new building has a first floor, ground floor and basement. There is disabled access to all levels.

\section{TECHNICAL INFORMATION ABOUT THE NEW BUILDING}

a) Floor area (in sq metres) for questions 24 to 33

24. $1,800 \mathrm{sq} m$ (new building only)

25. 959 sq $m$ approximately

27. $50 \mathrm{sq} m$ approximately

28. $205 \mathrm{sq} \mathrm{m}$ approximately

29. $19 \mathrm{sq} m$ approximately

33. 83 sq $m$ approximately

34. $124 \mathrm{sq} m$ approximately

35. $360 \mathrm{sq} m$ approximately

36. Number of levels: 3 (including basement)

37. 76 (new building only)

39. 17

40. 10

41. 49

b) Total potential capacity of shelving (linear metres or volumes)

42. $3047 \mathrm{~m}$ approximately (new building only)

43. 1,417 $\mathrm{m}$ approximately 
44. $1,630 \mathrm{~m}$ approximately

45. $1,213 \mathrm{~m}$

47. $247 \mathrm{~m}$ for archival material (of which $211 \mathrm{~m}$ is within compact shelving)

48. 5 (including Archives and Skilliter Centre)

\section{c) Mechanical features}

49. Main areas ventilated via displacement ventilation system. Closed stack area and IT Rooms ventilated by independent AHUs. Natural ventilation via openable windows in some areas.

50. Heating to main area supplied via air handling unit diffusers.

51. natural day-lighting; supplemented by artificial light provided by a combination of linear/compact fluorescent luminaires. Task lights to each desk also provided.

53. 1 lift

\section{SCHEDULE OF THE BUILDING PROCESS}

59. $1996-2000$

60. 2000

61. $2000 / 2001$

62. 2001

63. 2001-2003

64. end 2003

65. 2004

\section{E COSTS}

67. Main Contract $\mathrm{f} 5.786$ million plus VAT

Enabling works $\mathrm{f} 324,000$ plus VAT

68. Moveable (i.e. excluding shelving) $£ 97,000$

69. $f 908,000$

70. $\mathrm{f} 7,115$ plus VAT

\section{F PUBLICATIONS :}

- Hare, Nicholas: Cambridge connections : John Miller \& Partners' library at Newnham College ..., in: Architecture today, (2004), no. 148 (May), p. 34-36, 39-42, 45. ISSN 0958-6407.

- Wilson, Alison: Recent developments in Cambridge College Libraries, in: LIBER quarterly, 16 (2006), no. 2. 


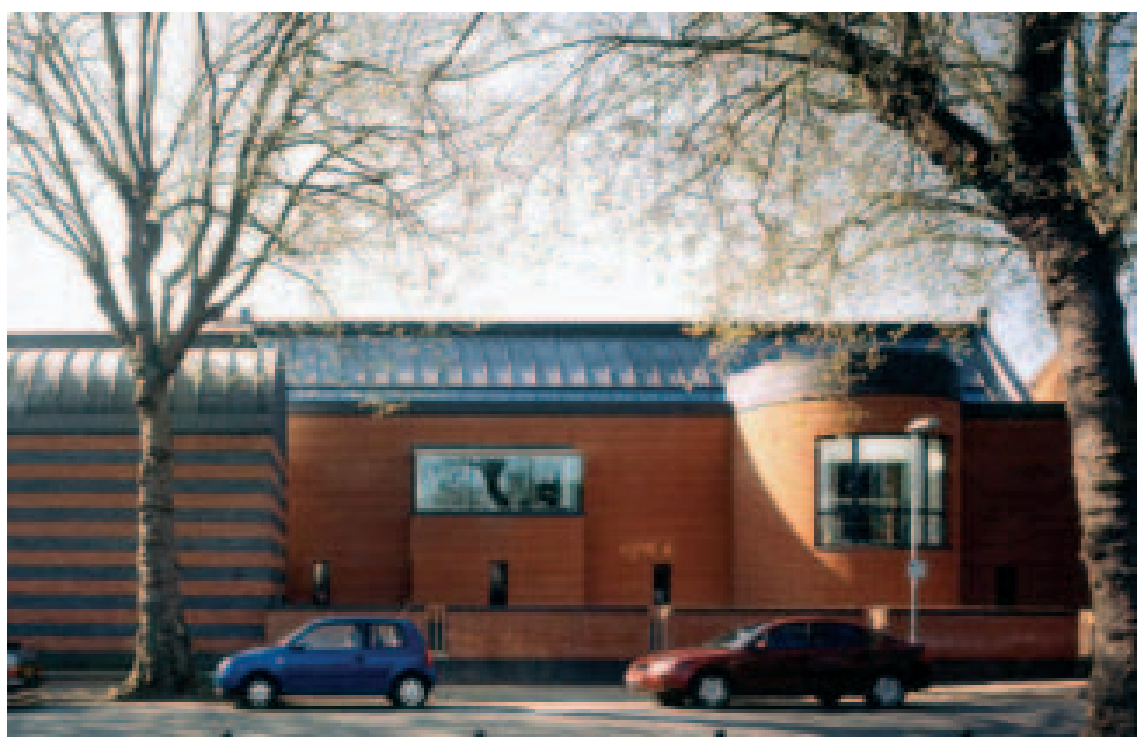

Newnham College Library, Views from Sidgwick Avenue

Photographs: Denis Gilbert

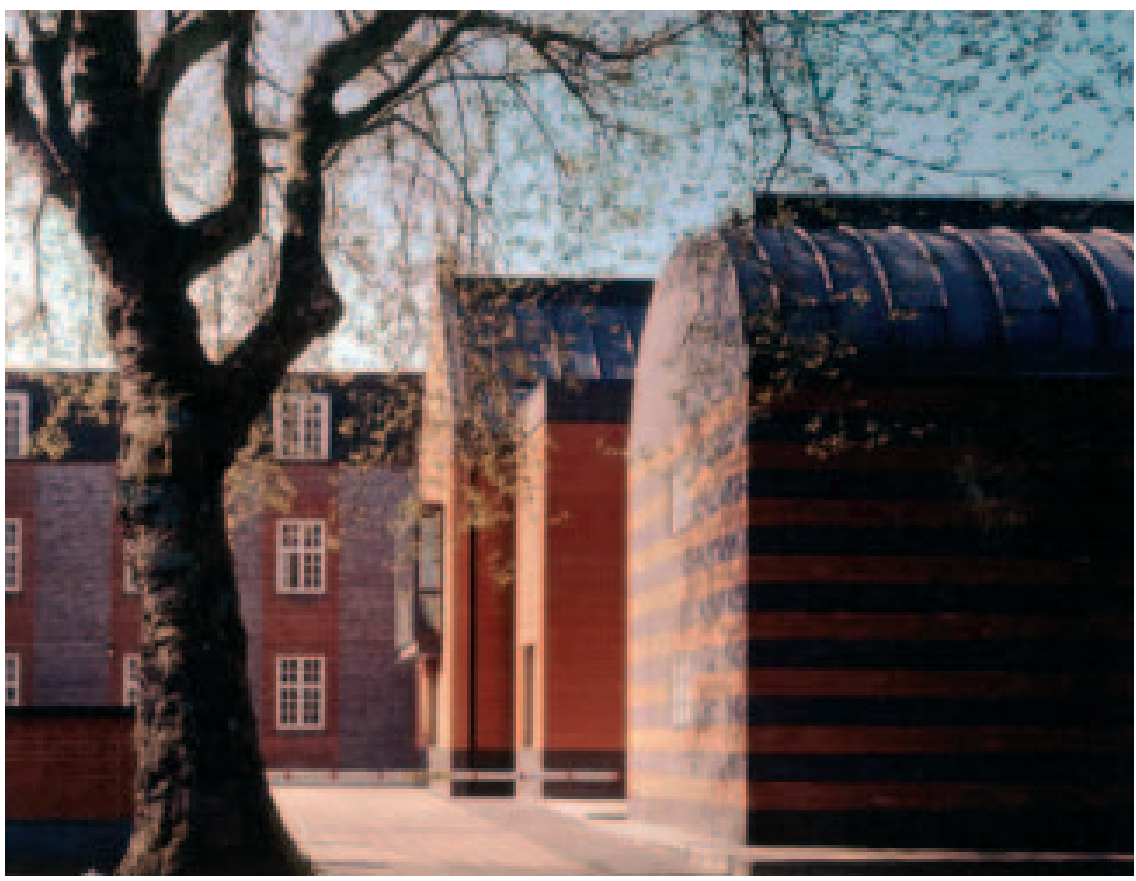



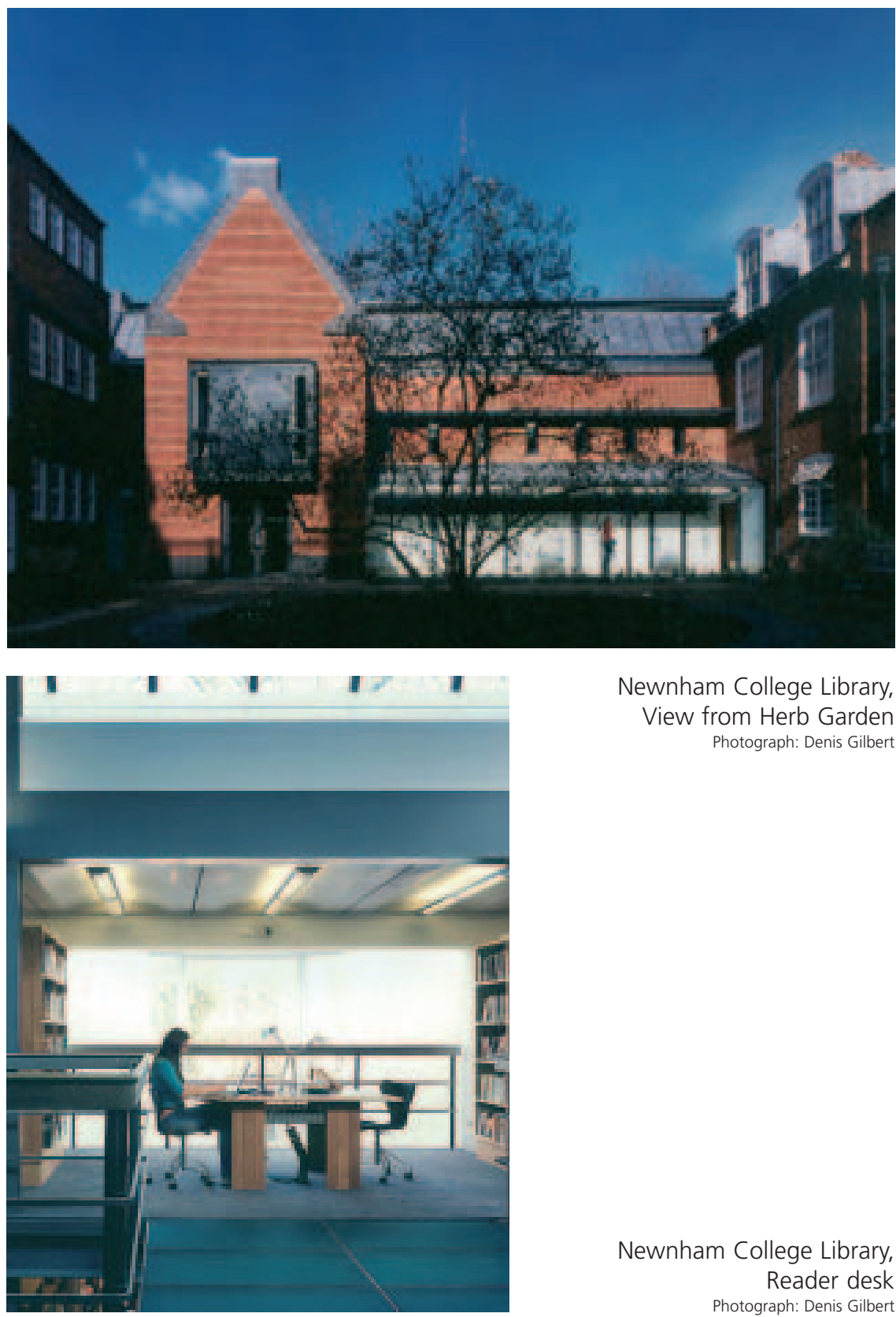

Newnham College Library, View from Herb Garden Photograph: Denis Gilbert

Newnham College Library, Reader desk Photograph: Denis Gilbert 


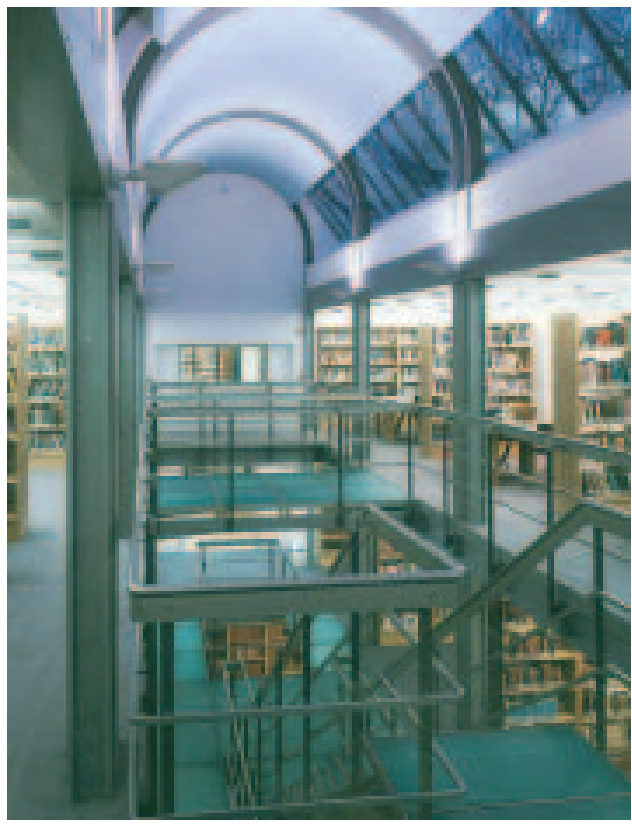

Newnham College Library, Barrel Vault Photograph: Denis Gilbert

Newnham College Library, Curved Bookcases Photograph: Denis Gilbert

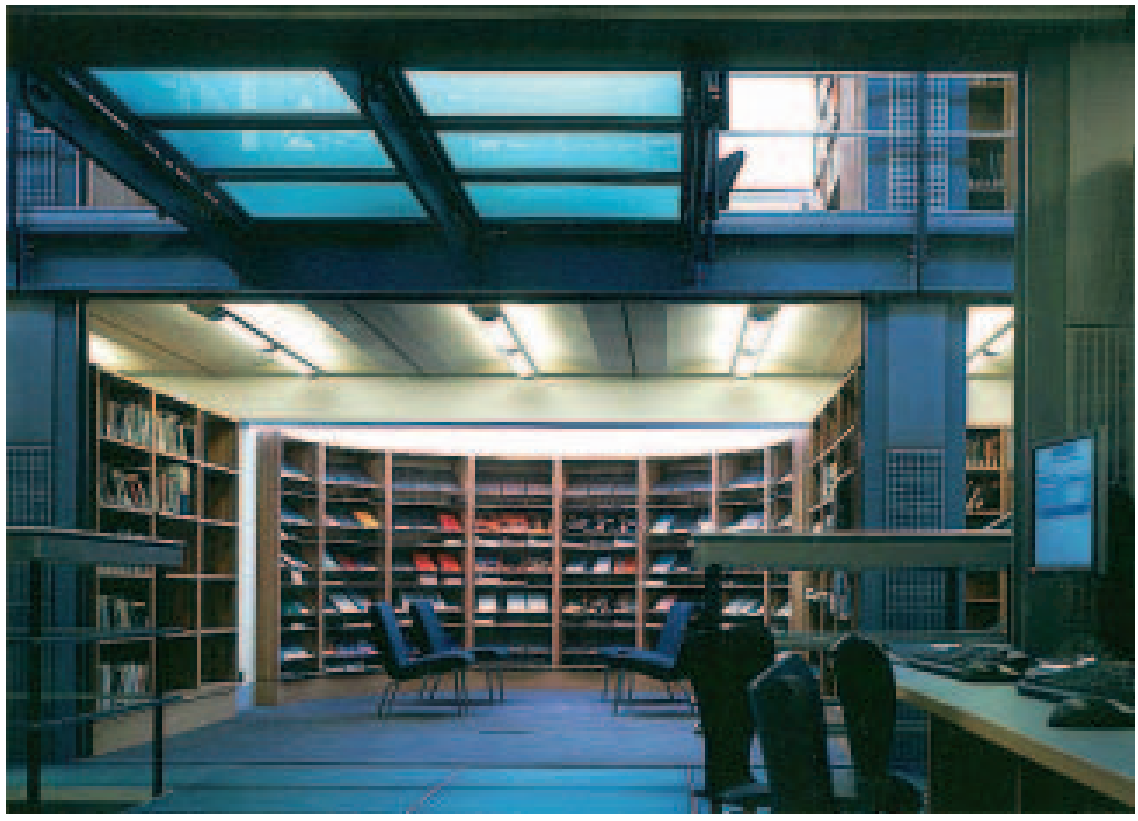




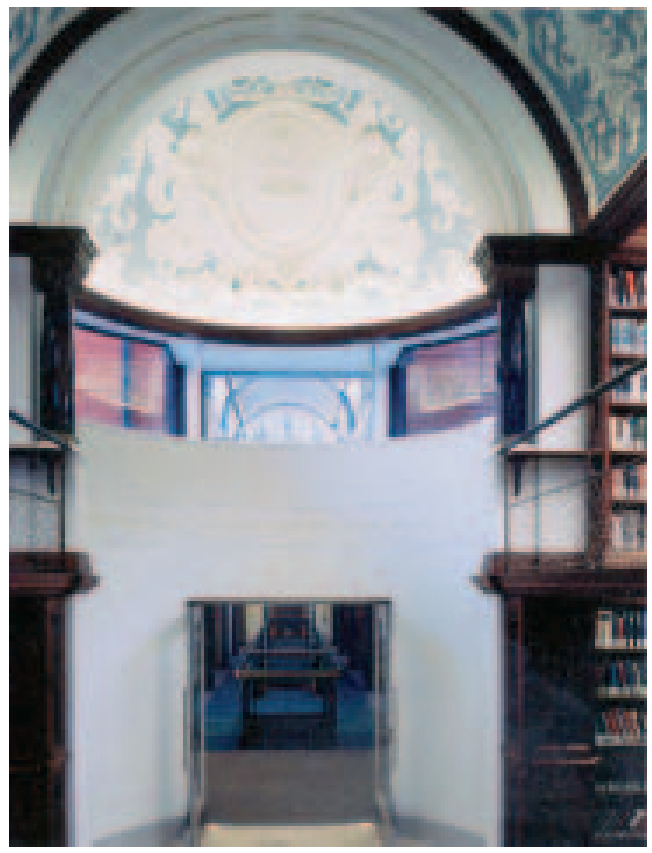

Newnham College Library,

Dome end

Photograph: Denis Gilbert 
Pembroke College Library 


\section{A GENERAL INFORMATION ABOUT THE LIBRARY}

a) Name and address

1. College library

2. Pembroke College Library

3. Trumpington Street, Cambridge CB2 1RF

4. Phone: 01223338121

E-mail: lib@pem.cam.ac.uk

5. Prof. T. R. S. Allan, Fellow Librarian

6. Patricia Aske, Assistant Librarian

b) Population served

7. 737

8. 650

10. 87 fellows

c) Conditions of the library (before the new project)

11. $310 \mathrm{sq} \mathrm{m}$

12. 62

13. 60000

14. 30000

15. 30000

16. 1.5

17. 22 weeks @ 16hrs, 29 weeks @ 14 hrs. 360 days per year

\section{B THE NEW BUILDING: AIMS AND FEATURES}

\section{a) Architect(s)}

18. Freeland Rees Roberts Architects, 25 City Road, Cambridge

19. Tristan Rees Roberts \& Sarah Morrison

20. Extension: yes

Renovation: yes

b) Aims of the new building

21. Short description of the main objectives and purposes of the project: More holdings in open stacks, more readers seats, extension to Victorian library 
to provide lift, staircase, offices, toilets, archives. New basement to provide storage for rare books and archives. Better lighting and heating. Complete refurbishment of the Old Library providing networked reader places.

\section{c) Special Features}

22. Location of the library is in the college central site. College is situated in the city centre, bus stop nearby.

23. The extension is a modern design which complements but does not compete with the Victorian original. Materials are red brick with two York stone pillars. The plan is rectangular with a glass stairway separating the extension from the original building. There are specially commissioned stained glass windows in the stairway and seminar room. A lift and ramp provide disabled access.

\section{TECHNICAL INFORMATION ABOUT THE NEW BUILDING}

\section{a) Floor area (in sq metres) for questions 24 to 33}

\section{4. $775 \mathrm{sq} \mathrm{m}$}

25. 2 main floors and separate Law Reading Room approx $400 \mathrm{sq} m$

26. $9 \mathrm{sq} \mathrm{m}$

28. $222 \mathrm{sq} m$

29. Yamada Room $25 \mathrm{sq} \mathrm{m}$

33. 3 staff offices on 3 floors, approx. $80 \mathrm{sq} \mathrm{m}$

35. Lift, corridors, stairs, cloakroom with 2 lavatories

36. 4 levels, basement is closed access

37. 125

40. 14

41. 111

b) Total potential capacity of shelving (linear metres or volumes)

42. 90000

43. 46000

44. 44000

48. Ideally 2.5 (but currently 1.5 ) 


\section{c) Mechanical features}

49. For rare books in basement only. All other areas are naturally ventilated

50. Radiators heated by college central boilers

51. Desk lights improved

53. 1 passenger lift

54. trolleys

55. book security system

57. wireless network added

\section{SCHEDULE OF THE BUILDING PROCESS}

62. July 2000

63. 15 months

65. June 2001

\section{E COSTS}

70. $\mathrm{f} 2.45$ million

\section{F PUBLICATIONS:}

Wilson, Alison: Recent developments in Cambridge College Libraries, in: LIBER quarterly, 16 (2006), no. 2. 
Pembroke College Library All Photographs: Nick Carter
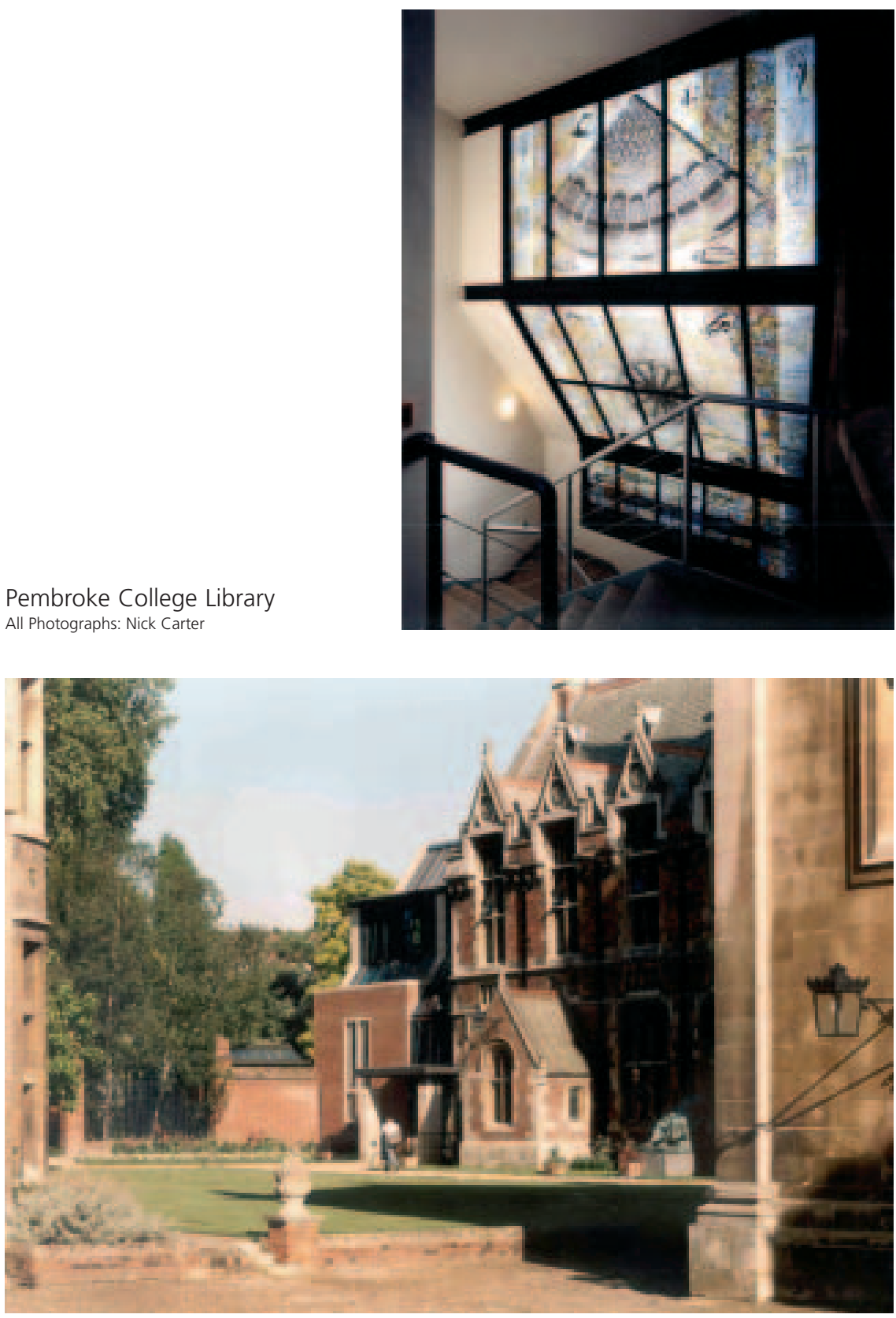

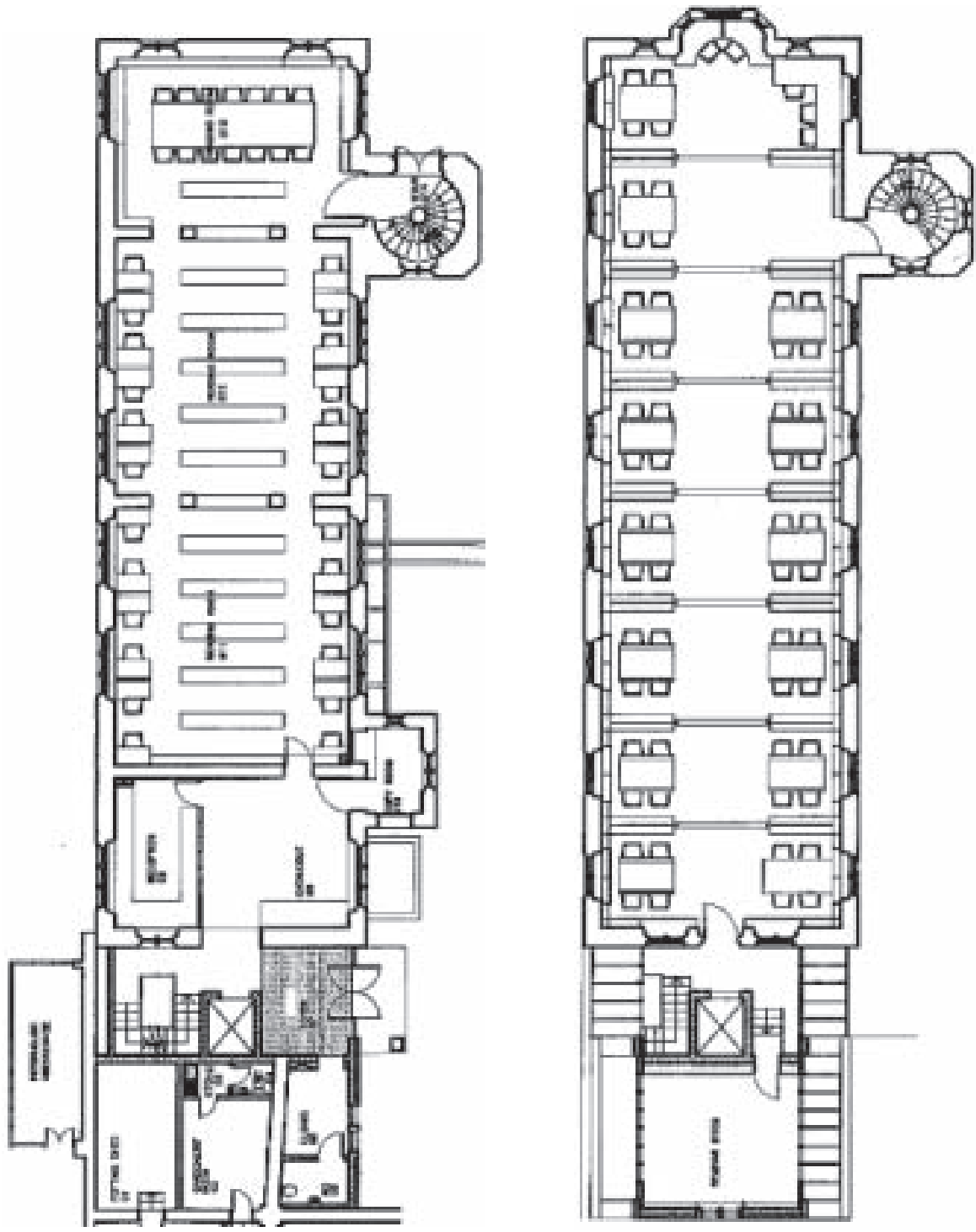

Pembroke College Library

Ground floor

First floor

Freeland Rees Roberts Architects 


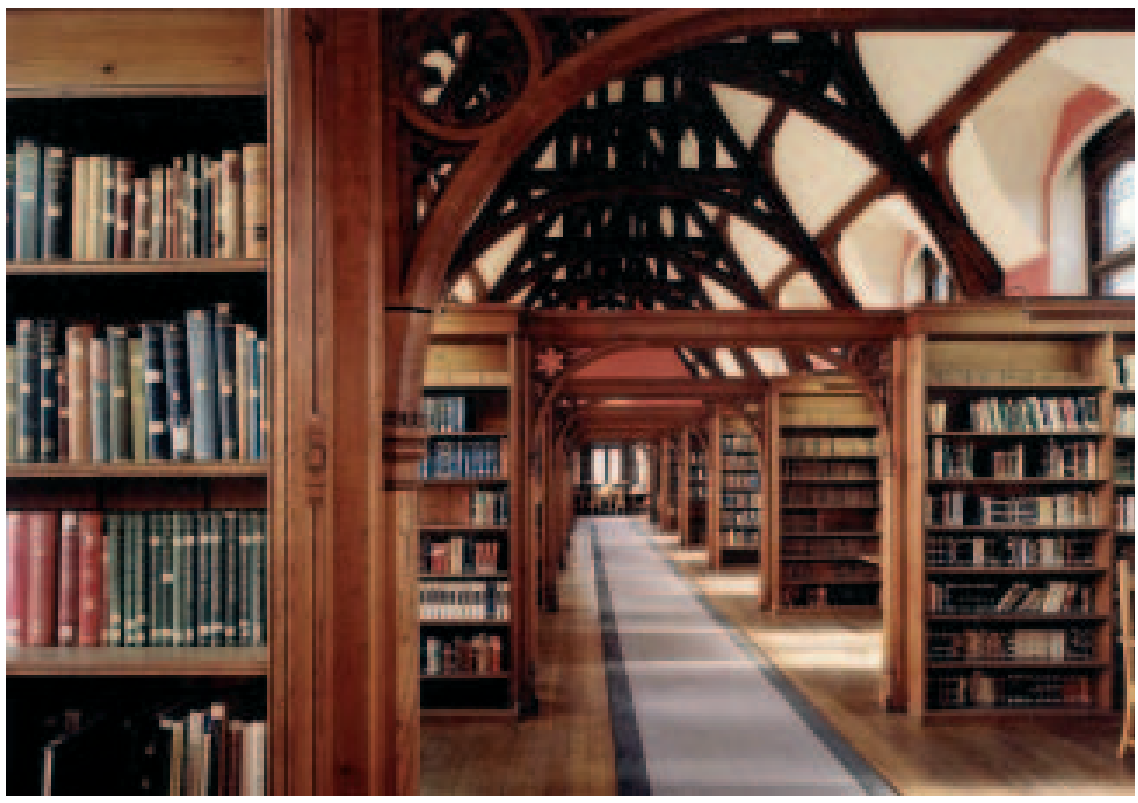

$\uparrow$ Old Library after renovation $\downarrow$ Yamada Room

Photograph: Nick Carter Photograph: Nick Carter

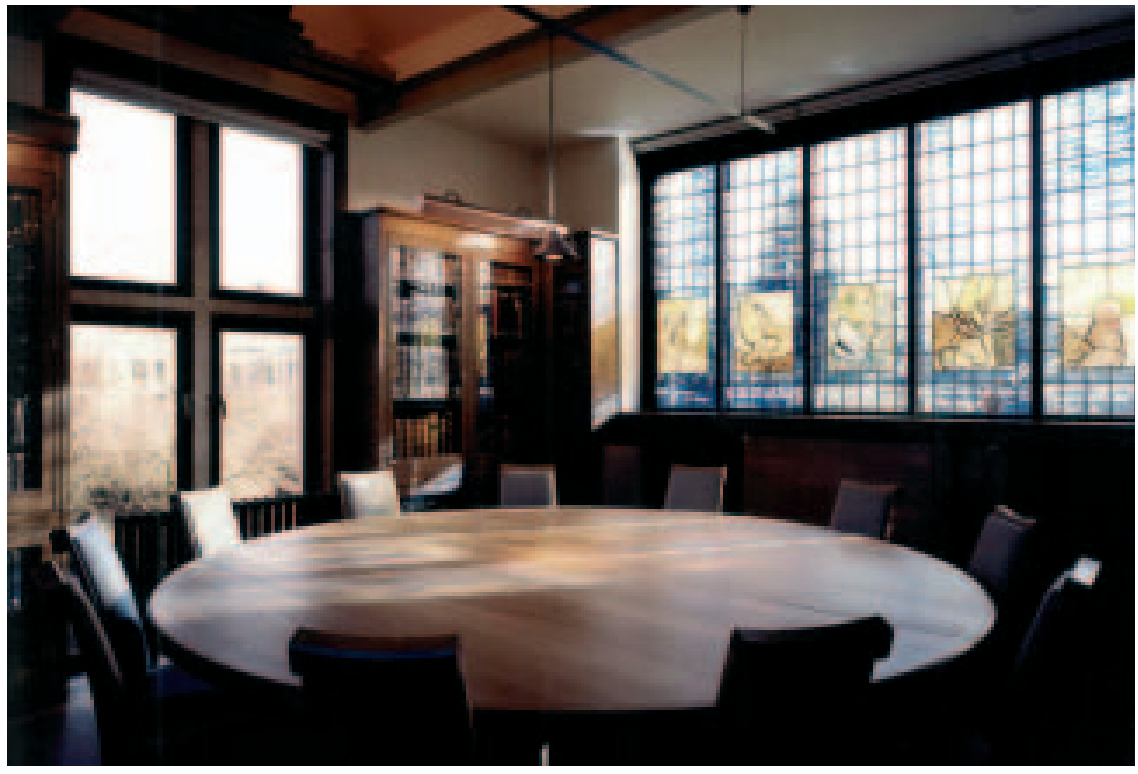





\section{Peterhouse -}

\section{Ward Library Gunn Gallery}




\section{A GENERAL INFORMATION ABOUT THE LIBRARY}

a) Name and address

1. Academic

2. Gunn Gallery, Ward Library

3. Peterhouse

Cambridge

CB2 1RD, UK

4. Phone: 01223338218

E-mail: lib@pet.cam.ac.uk

5. Mr M S Golding

6. Ms E A McDonald

b) Population served

7. 400

8. 350

10. 50

c) Conditions of the library (before the new project)

11. $703 \mathrm{sq} \mathrm{m}$

12. 70

13. 50,000 volumes

14. 40,000

15. 10,000

16. 1

17. Term 09.00-24.00 daily

Vacation $09.00-12.45,14.00-17.00$

\section{B THE NEW BUILDING: AIMS AND FEATURES}

a) Architect(s)

18. Freeland Rees Roberts

19. Rowan Haysom, Tristan Rees-Roberts

20. Extension: yes

Renovation: yes 
b) Aims of the new building

21. To provide space for 24 desks, 20,000 more books, 6 computer workstations, and to install internet network connections at the desks

c) Special Features

22. Part of existing College buildings

23. Refurbishment of existing building previously unused

\section{TECHNICAL INFORMATION ABOUT THE NEW BUILDING}

a) Floor area (in sq metres) for questions 24 to 33

24. $250 \mathrm{sq} \mathrm{m}$

25. $210 \mathrm{sq} \mathrm{m}$

27. $20 \mathrm{sq} \mathrm{m}$

35. $20 \mathrm{sq} \mathrm{m}$

36. 2

37. 30

39. 6

41. 24

b) Total potential capacity of shelving (linear metres or volumes)

42. 24,000

43. 20,000

44. 4,000

c) Mechanical features

49. Extension of existing air circulation system and air-con in two computer rooms

50. Extension of existing heating system

51. Improved automatic lighting at various levels

53. 1

57. Category 5E

and capacity: 28 outlets

speed of connection (switched 100mbit Ethernet). 


\section{SCHEDULE OF THE BUILDING PROCESS}

59. $2^{\text {nd }}$ July 2001

60. $25^{\text {th }}$ May 2002

62. July 2004

63. July $2004-J u l y ~ 2005$

64. August-September 2005

65. 1. 10.2005

\section{F PUBLICATIONS :}

Wilson, Alison: Recent developments in Cambridge College Libraries, in: LIBER quarterly, 16 (2006), no. 2.

\section{AWARDS}

The Gunn Gallery awards from the Royal Institute of British Architects (National and Local) are:

- RIBA. Conservation 2006. Commendation

- RIBA East. Spirit of Ingenuity Heritage Award 2006. Winner

- RIBA East. Spirit of Ingenuity Education Award 2006. Commendation. 


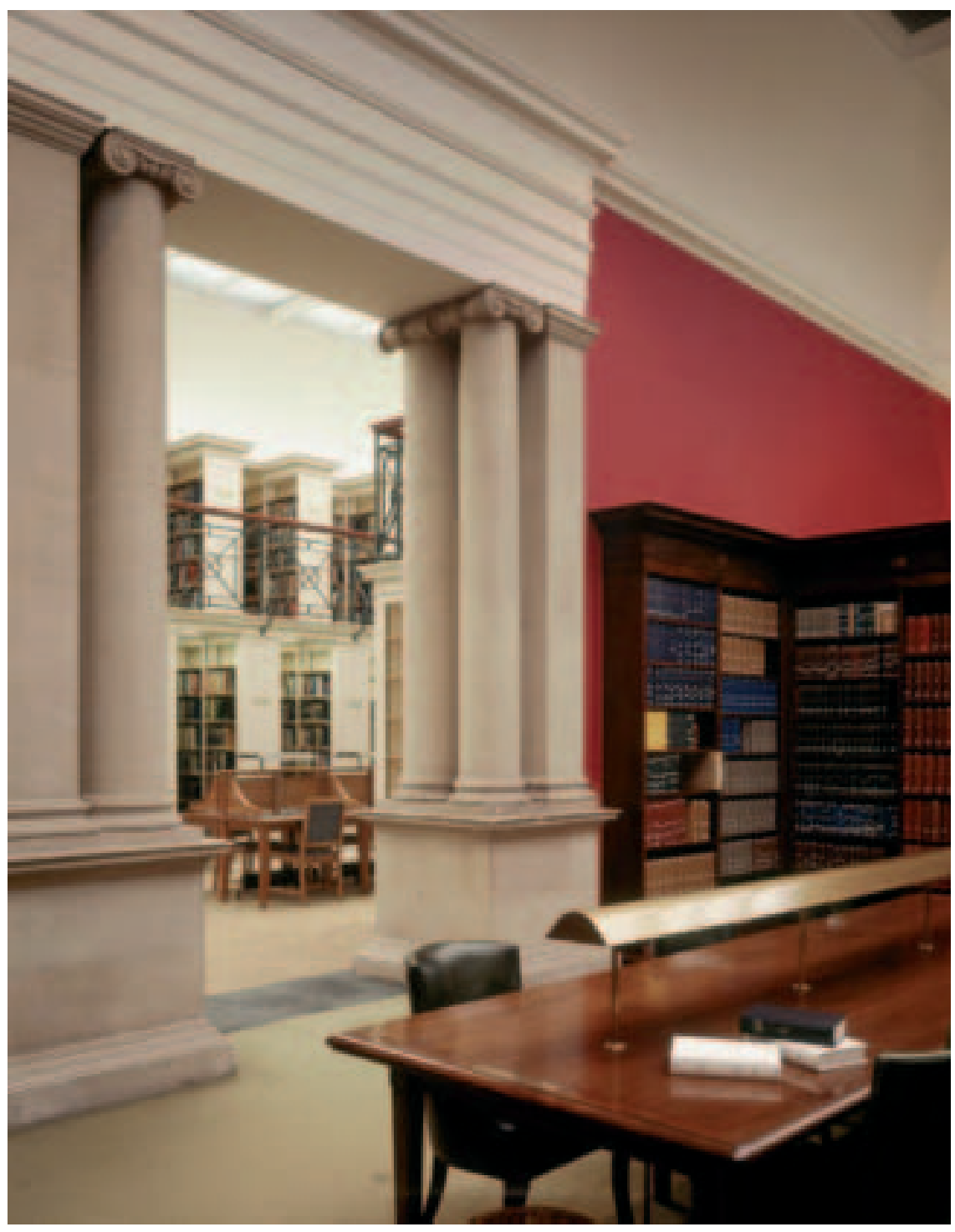

Peterhouse - Ward Library Gunn Gallery Archway

Photograph: Freeland Rees Roberts 


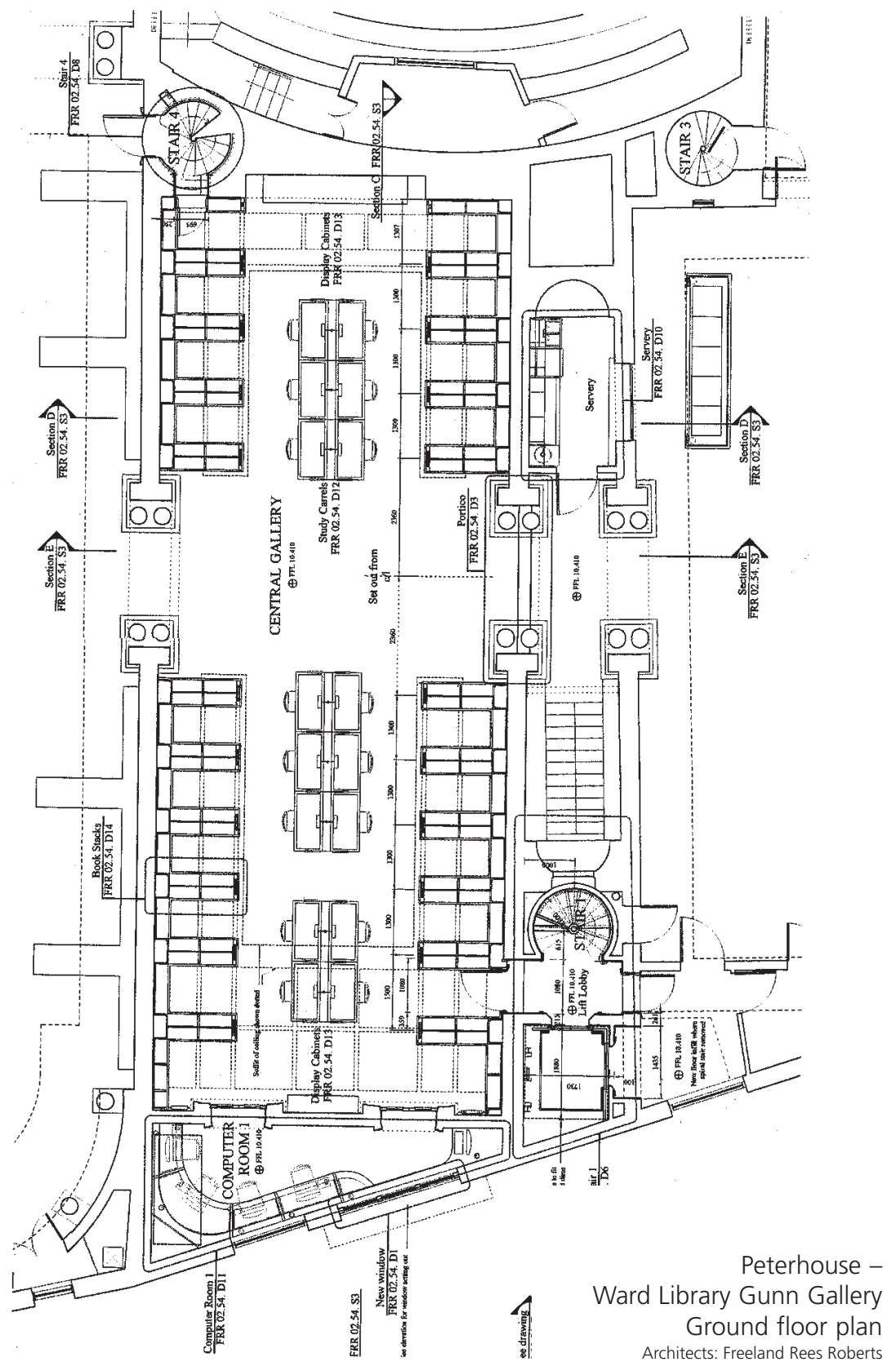




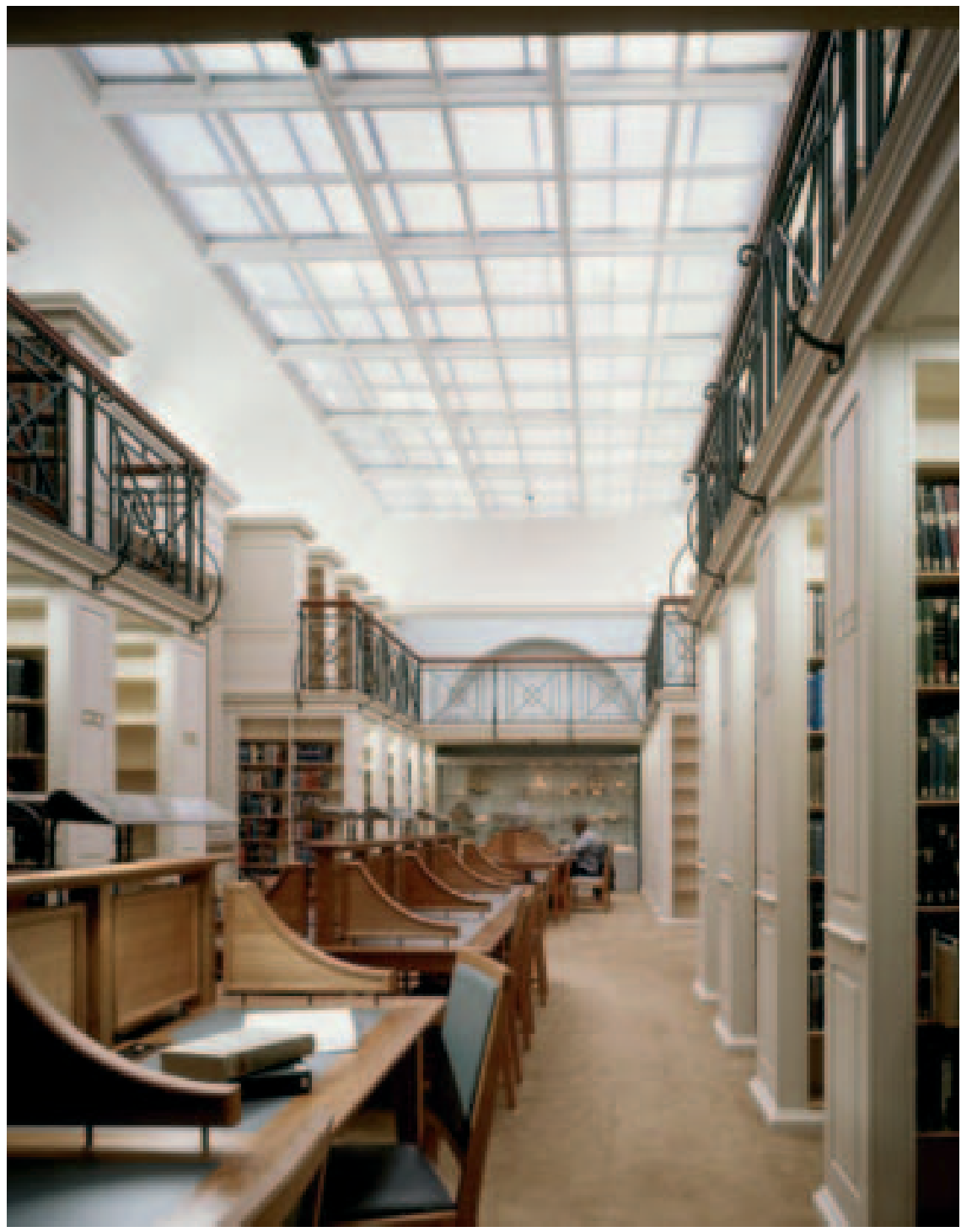

Peterhouse - Ward Library Gunn Gallery Ground floor - Looking eastwards

Photograph: Freeland Rees Roberts 


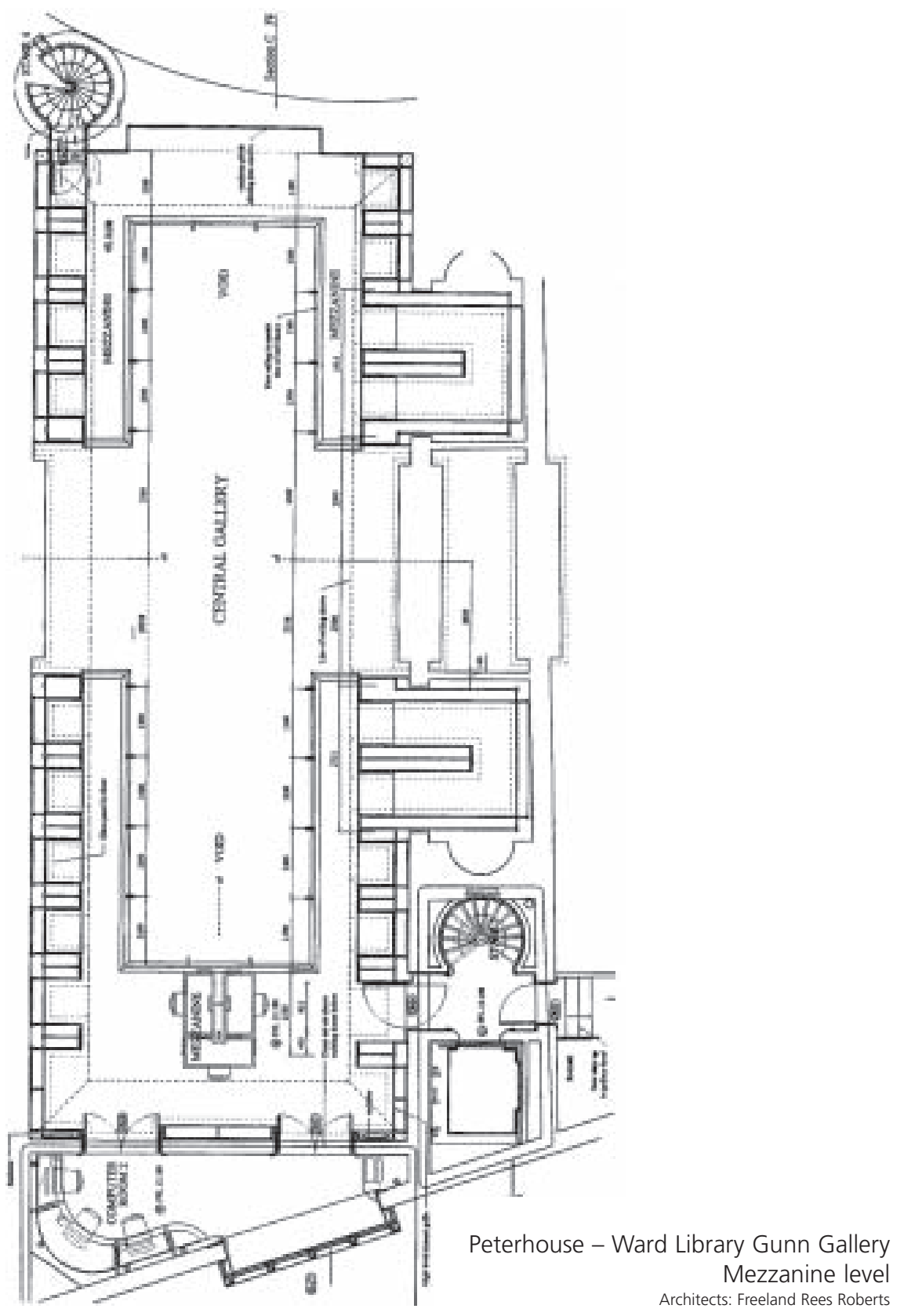




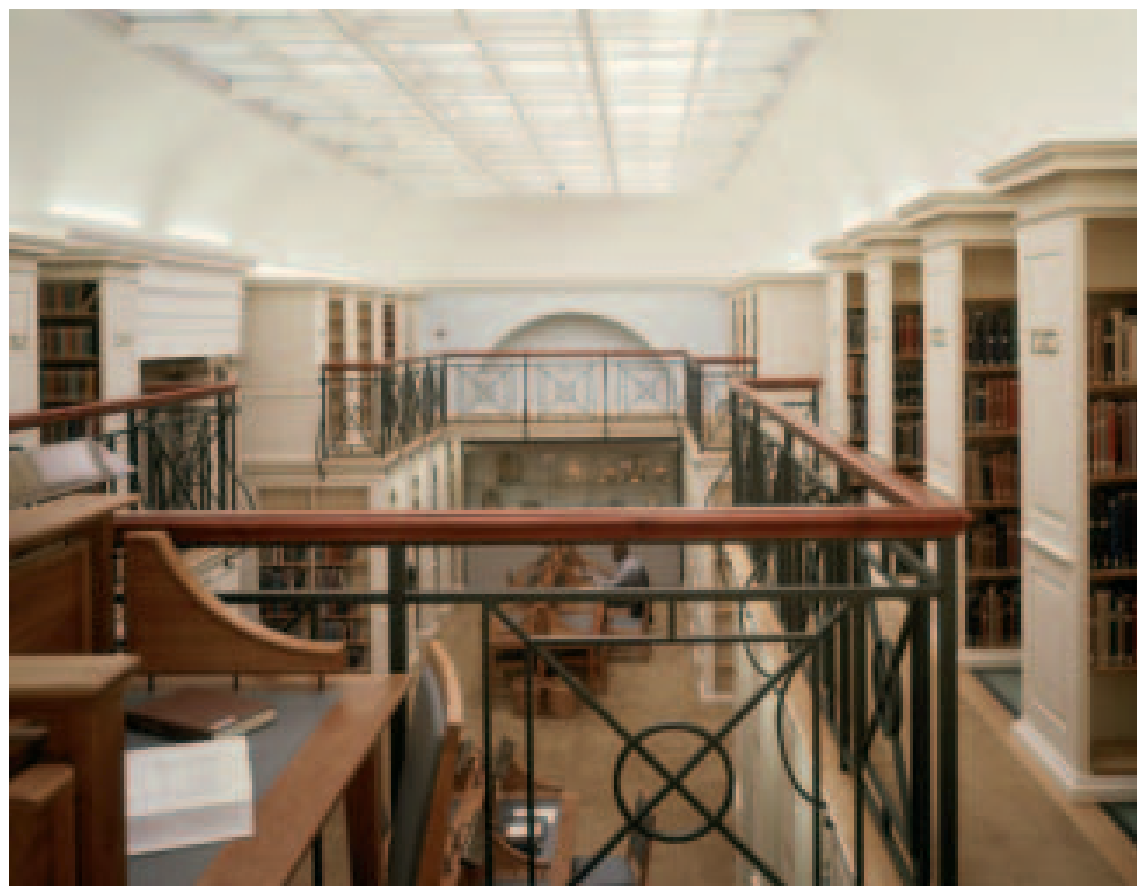

Peterhouse - Ward Library Gunn Gallery Mezzanine level - Looking eastwards Photograph: Freeland Rees Roberts 


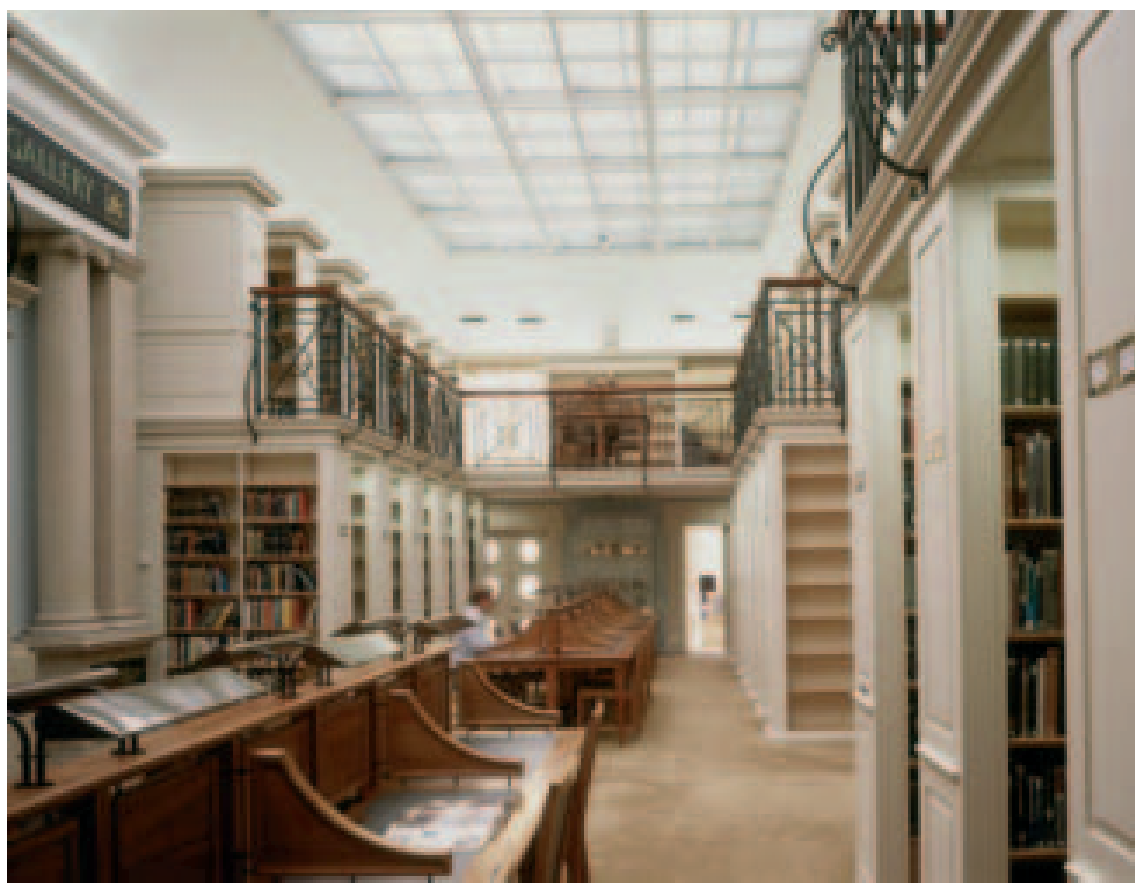

Peterhouse - Ward Library Gunn Gallery Ground floor - Looking westwards

Photograph: Freeland Rees Roberts 
St John's College Library 


\section{A GENERAL INFORMATION ABOUT THE LIBRARY}

a) Name and address

1. College Library

2. St John's College Library

3. Cambridge CB2 1TP

4. Phone: 01223338661

Fax: 01223337035

E-mail:amn1000@cam.ac.uk

5. Dr Mark Nicholls

6. Dr Mark Nicholls

b) Population served

7. 1100

8. 820

9. 5

10. 140 Fellows plus 20 regular Assistant Staff users

c) Conditions of the library (before the new project)

12. $50 \max$

16. 6.5 (1991)

17. We introduced $24 / 7$ opening throughout the year only with the completion of the New Library Project.

\section{B THE NEW BUILDING: AIMS AND FEATURES}

\section{a) Architect(s)}

18. Edward Cullinan

19. Colin Rice

20. New building: Yes (in part)

Extension: $\quad$ Yes (in part)

Renovation: Yes (in part)

The 1991-4 project included all three.

b) Aims of the new building

21. To offer efficient and effective modern library services to all junior and resident senior members of the College. 


\section{c) Special Features}

22. Complete reconstruction of a late nineteenth-century College building designed by Francis Penrose, retaining only the outer walls. Involves addition of two completely new wings. Refurbishment element of the project focused on an early seventeenth-century Grade 1 listed building.

23. In the Working Library - space is divided over six floors, including a basement, to offer facilities on each floor particular to the subject collections housed there. Two dedicated Computer Rooms, with trunking to all desks in the Library, allowing easy subsequent upgrade of facilities. Seminar Room. Audio Visual Room. Separate Law Library. Climatically controlled Basement stacks suitable for storing more fragile/rare collections.

Old Library refurbishment designed to restore for Special Collections use an area long utilised as part of an undergraduate library. Provision of wellequipped Rare Books Reading Room and secure facilities in which to store special collections in accordance with BS5454.

Strong emphasis on disabled access throughout the building.

\section{TECHNICAL INFORMATION ABOUT THE NEW BUILDING}

\section{a) Floor area (in sq metres) for questions 24 to 33}

24. (including Old Library) $1980 \mathrm{sq} \mathrm{m}$

25. Open every day and night throughout the year

26. c. $15 \mathrm{sq} \mathrm{m}$

27. Now throughout Library

28. c. $30 \mathrm{sq} \mathrm{m}$ in Working Library Basement (in addition to extensive shelving in Old Library)

29. c. $20 \mathrm{sq} \mathrm{m}$

30. c. 25

32. vending machine facility only

33. $50 \mathrm{sq} \mathrm{m}$

34. $200 \mathrm{sq} \mathrm{m}$ (in Working Library only - all collections in the Old Library are closed access)

36. The Working Library is now on 6 levels, including a Basement and a Mezzanine Floor. Refurbished Old Library remains on two levels.

37. 120 (in Working Library); 189 (in Old and Working Libraries)

38. 5 
39. 55 (but laptops can connect to the internet from any seat)

40. 15

41. 45

b) Total potential capacity of shelving (linear metres or volumes)

42. $3000 \mathrm{~m}$ (Working Library only)

43. $2800 \mathrm{~m}$

44. $200 \mathrm{~m}$ (in Working Library - much more available in Old Library already)

45. 20,000 volumes

46. 1500 videos, DVDs and CD-ROMs

47. 500 modern maps in Working Library

48. 8.5 (including 1.0 cleaning)

\section{c) Mechanical features}

49. Air Conditioning only in the Basement, Plant Machine/IT Room, and Manuscripts

Cabinet. Otherwise, natural ventilation, exploiting thermal mass of building.

50. Oil-fired radiators

51. Fluorescent ceiling lights; wall lights and desk lights

52. Carpeting on some stairs. Acoustic material on ceiling

53. One lift

54. Trolleys!

55. Card access system with book alarm

56. Temperature only

\section{SCHEDULE OF THE BUILDING PROCESS}

59. 1990-1

60. Closed competition -1991

62. 1991-2

63. 1992-4 for all phases

64. $1993-4$

65. late 1993 for Working Library, refurbishment of Old Library in 1994

\section{E COSTS}

70. f 3.25 million 


\section{F PUBLICATIONS:}

- Brochure 1993 - technical details now superseded in places.

- Davey, Peter: Literary device : Library, St. John's College, Cambridge, England, in: Architectural review, 194 (1994), no. 1166, p. [30]-34. ISSN 0003-861X.

- Rice, Colin: The New Library at St John's College, in: The Eagle, (1995), p. 37-47.

- St John's : excellency and diversity, D. Morphet, ed., Third Millenium Publishing (forthcoming 2007). 


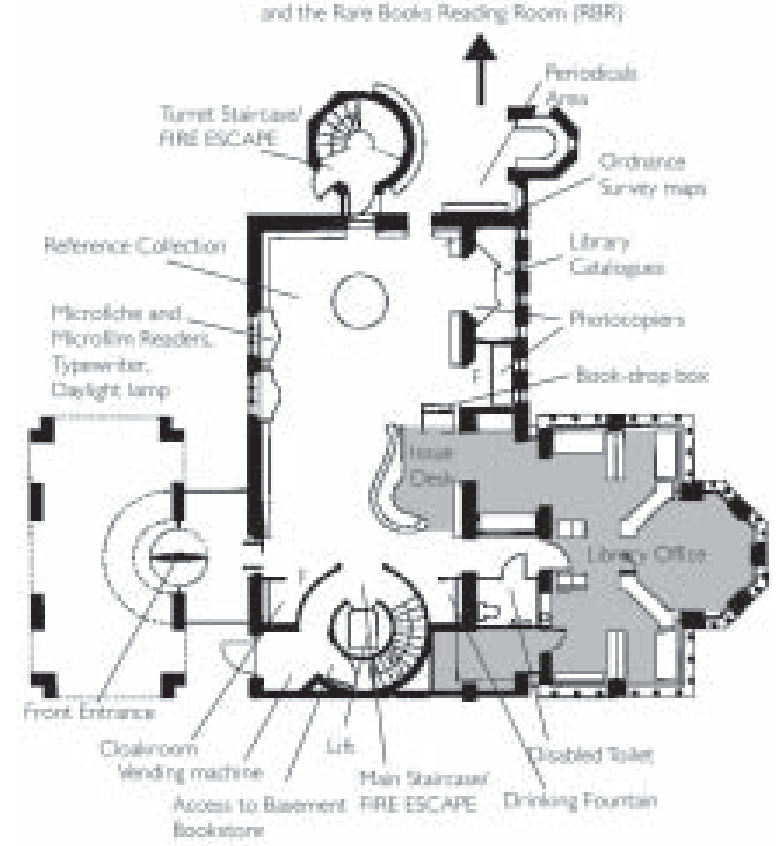

St. John's College Library, Ground floor plan Edward Cullinan, Architect

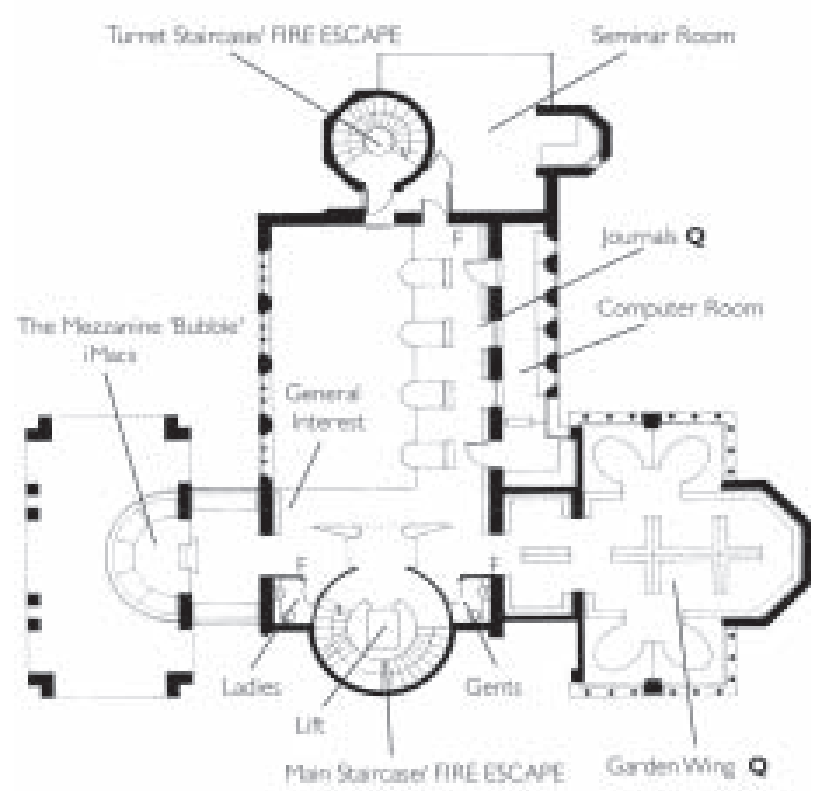

St. John's College Library, Mezzanine plan Edward Cullinan, Architect 


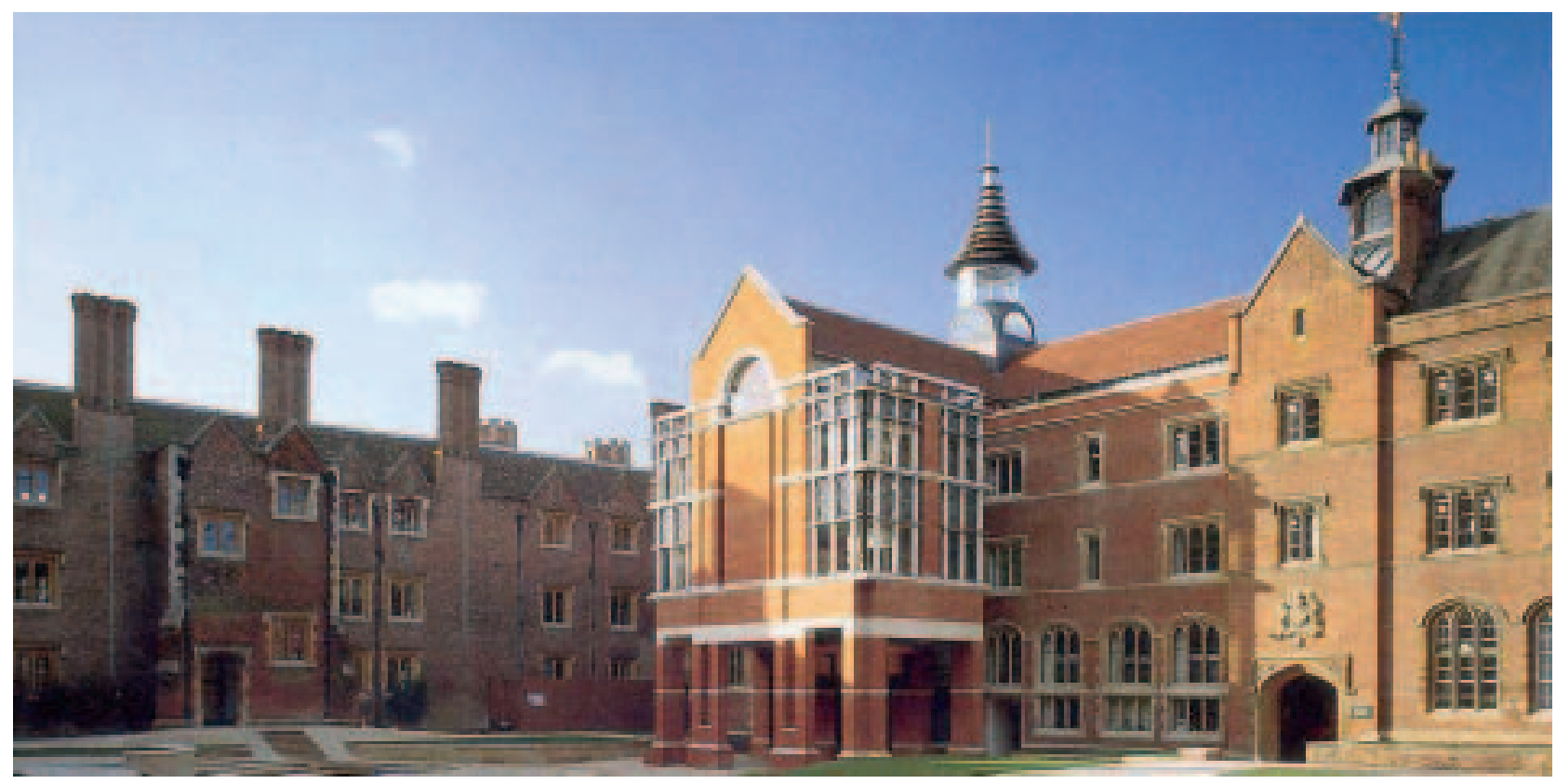




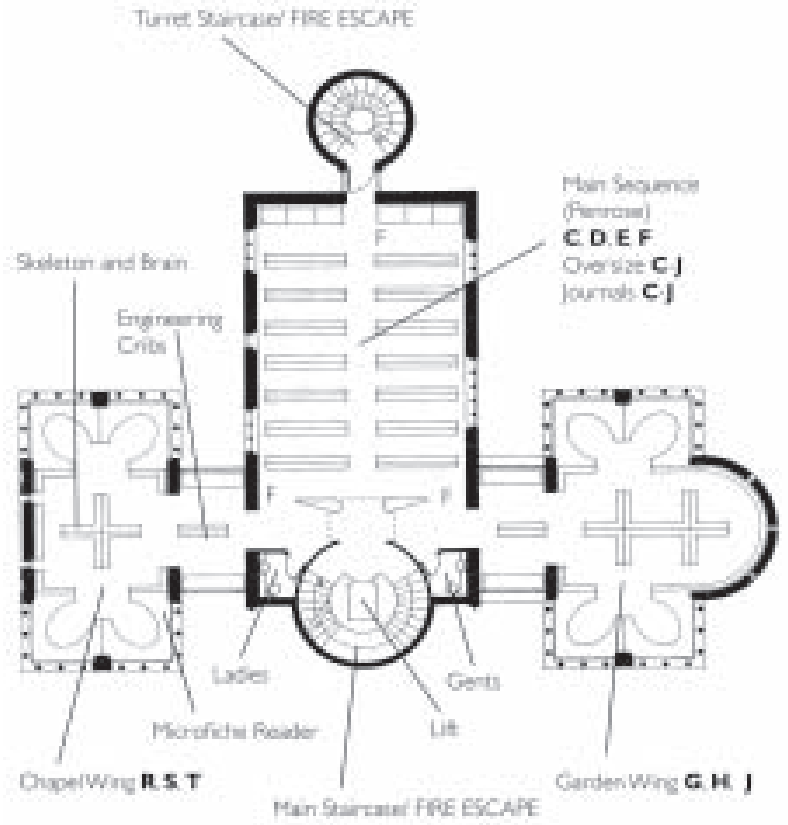

St. John's College Library, Second floor plan Edward Cullinan, Architect

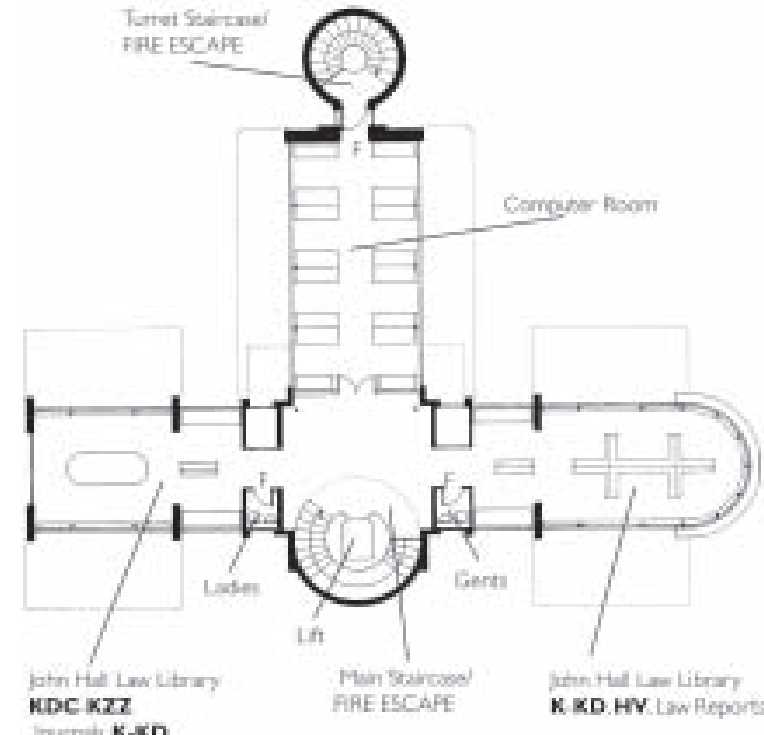

St. John's College Library, Third floor plan Edward Cullinan, Architect 


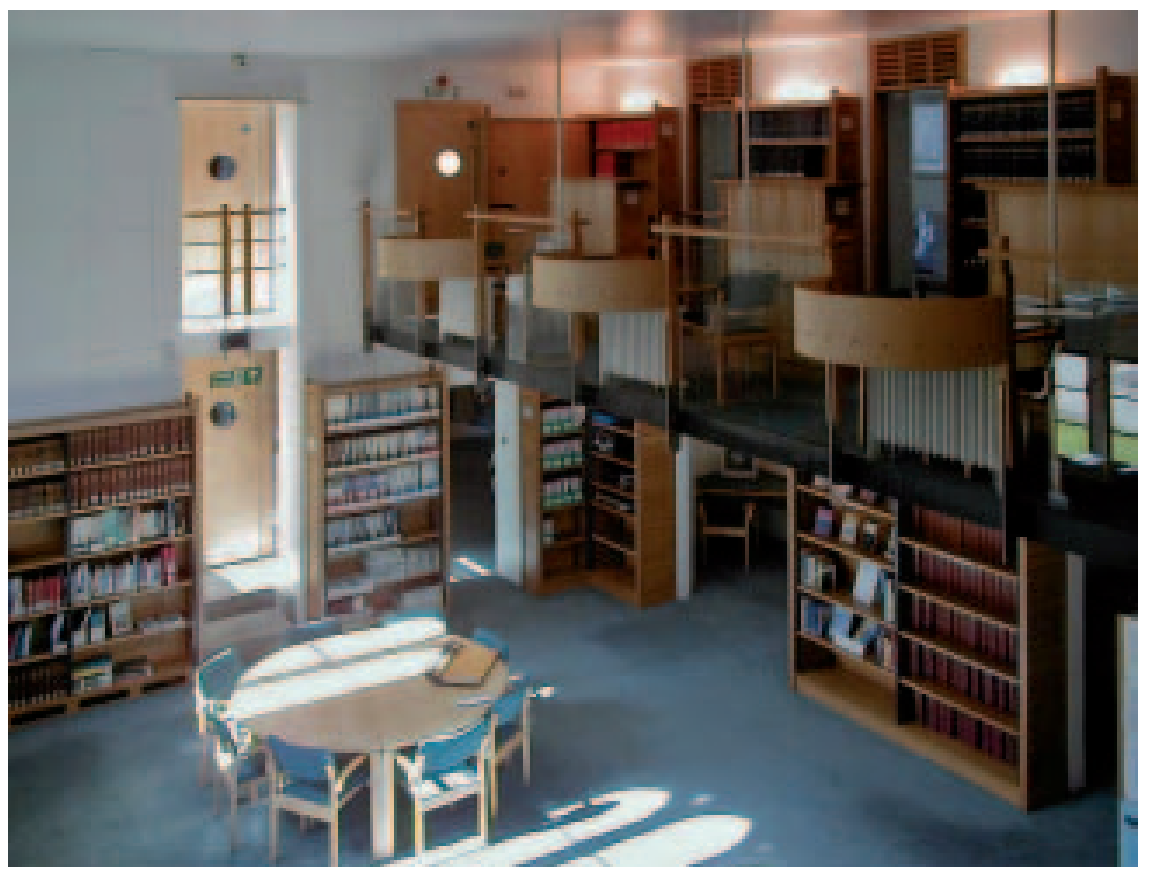

St. John's College Library, View of the entrance hall from the Mezzanine gallery (c) St. John's College, Cambridge 


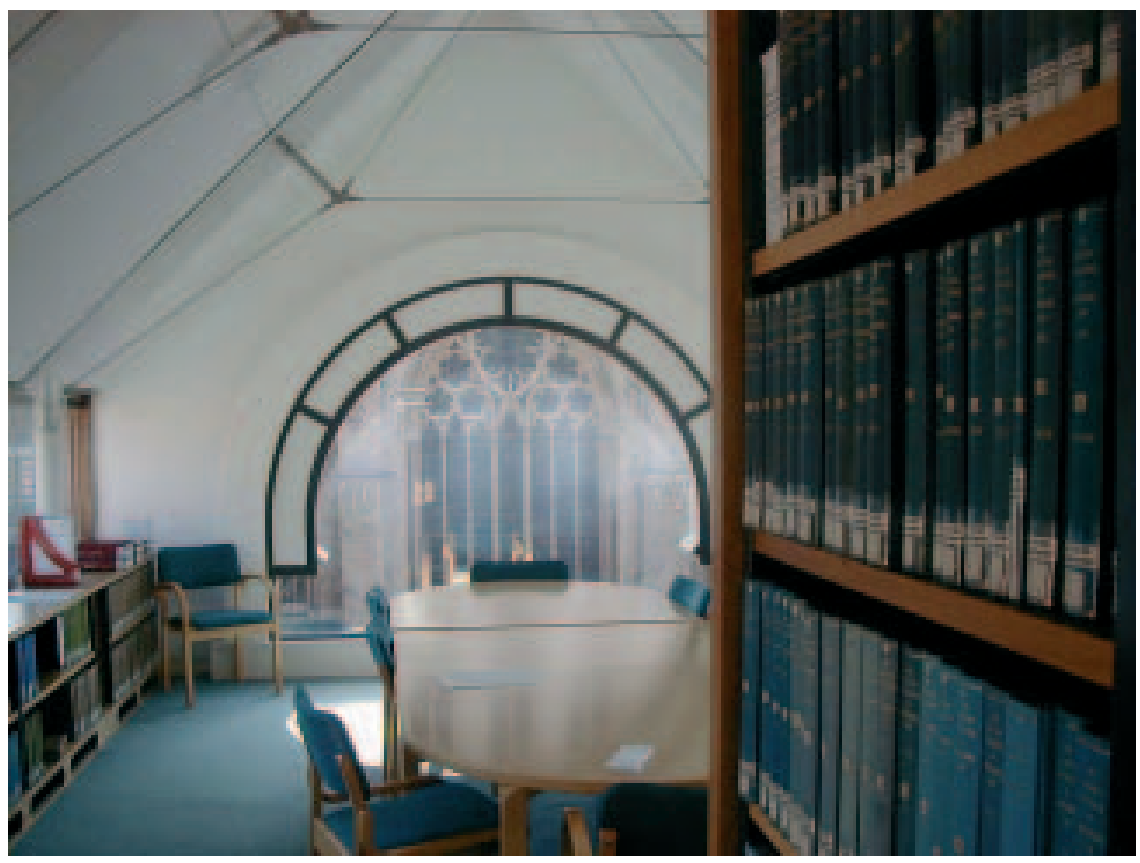

St. John's College Library, Third floor, Oriel window (c) St. John's College, Cambridge 


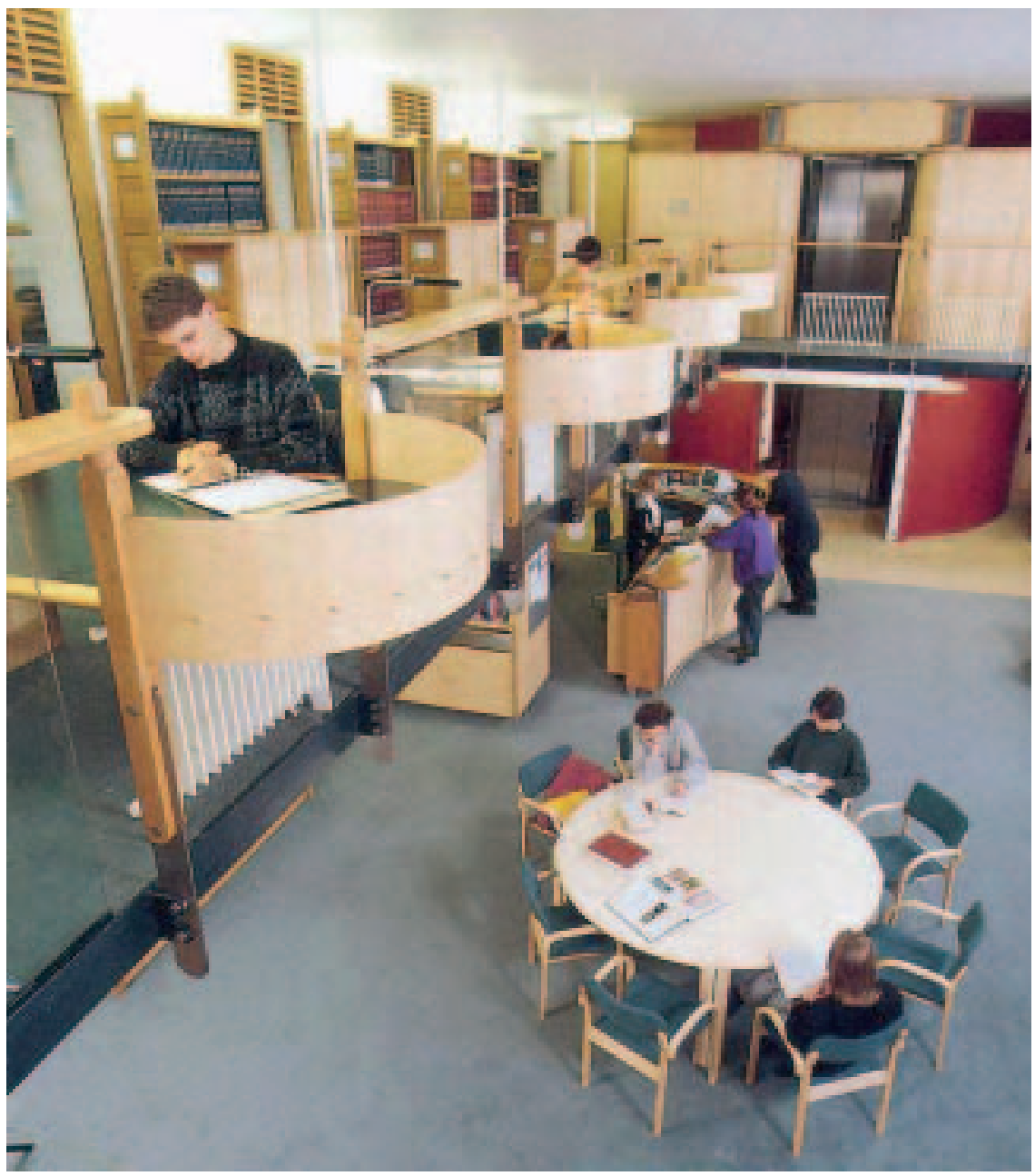

St. John's College Library, View of the entrance hall from the Mezzanine gallery (c) St. John's College, Cambridge 


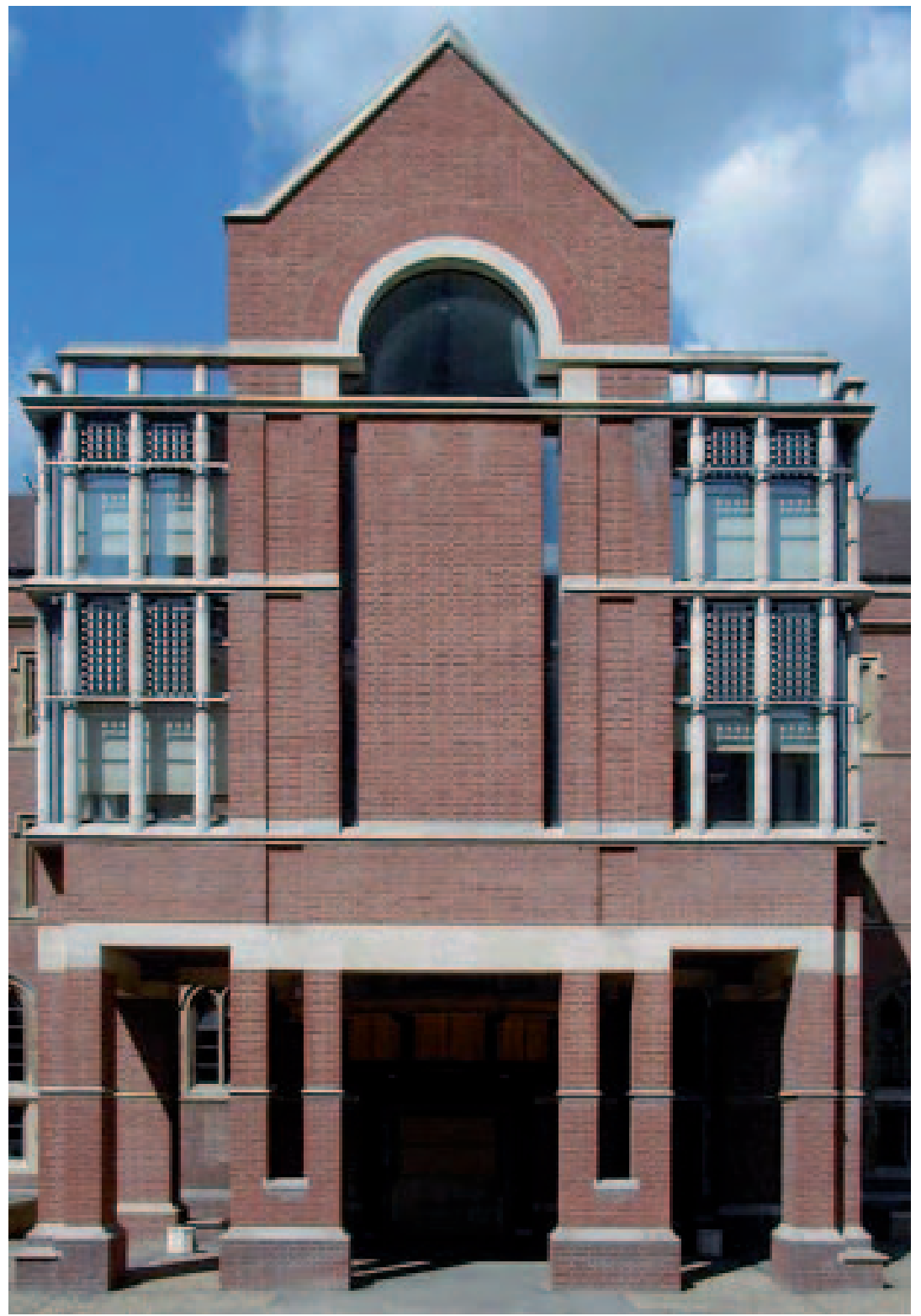

St. John's College Library, Façade 
Trinity Hall -

Jerwood Library 


\section{A GENERAL INFORMATION ABOUT THE LIBRARY}

a) Name and address

1. College Library (Undergraduate working library)

2. Jerwood Library

3. Trinity Hall, Trinity Lane, Cambridge CB2 1TJ, UK

4. Phone: (0)1223 332546

Fax: (0)1223 332537

E-mail: library@trinhall.cam.ac.uk

5. Dr. John Pollard, Fellow Archivist and Librarian

6. Dominique Ruhlmann, Director of Library Services

b) Population served

7. 528

8. 610

9. 5

10. 88

c) Conditions of the library (before the new project)

11. $100 \mathrm{sq} \mathrm{m}$ approximately

12. 24

13. 22,000 books

14. 22,000 books (including 12,500 books on mobile shelves)

16. 1

17. 168 hrs per week 355 days per year

\section{THE NEW BUILDING: AIMS AND FEATURES}

\section{a) Architect(s)}

18. Freeland Rees Roberts Architects

19. Tristan Rees Roberts and Graham Riley

20. Extension: yes

b) Aims of the new building

21. Larger total floor area, more holdings in open stacks, more readers seats, computer materials. 


\section{c) Special Features}

22. On the banks of the River Cam on Trinity Hall central site. The site available was very small (originally a gardener's store) and every square metre had to be utilised.

23. The principal library spaces in their angled and stepped configuration take full advantage of spectacular views of the river Cam and the Backs. Views are broken and framed by heavy oak mullions which preserve a good measure of internal privacy, given the close proximity of Garret Hostel Lane and Bridge.

Disabled access: Yes - a lift and ramp

\section{TECHNICAL INFORMATION ABOUT THE NEW BUILDING}

\section{a) Floor area (in sq metres) for questions 24 to 33}

24. $413 \mathrm{sq} \mathrm{m}$

25. Law reading room $=37.5 \mathrm{sq} \mathrm{m}$

Lower ground floor reading room $=50 \mathrm{sq} \mathrm{m}$

Mezzanine reading room $=78 \mathrm{sq} \mathrm{m}$

Ground floor reading room $=67 \mathrm{sq} \mathrm{m}$

First floor reading room $=38 \mathrm{sq} \mathrm{m}$

Second floor reading room $=38 \mathrm{sq} \mathrm{m}$

27. 1 Computer room with $20 \mathrm{PCs}=43 \mathrm{sq} \mathrm{m}$

28. 1 room, containing 3 special collections $=67 \mathrm{sq} \mathrm{m}$

(N.B. This room is the Ground floor reading room listed above)

29. 1 room $=34 \mathrm{sq} \mathrm{m}$

32. No cafeteria ( 1 water cooler in photocopying room)

33. 2 Librarian's offices $=14.5 \mathrm{sq} \mathrm{m}$ (one office $=10 \mathrm{sq} \mathrm{m}$; second office $4.5 \mathrm{sq} \mathrm{m}$ ) $1 \mathrm{staff}$ coffee room $=4.5 \mathrm{sq} \mathrm{m}$

34. 7,000 special collections books in locked glass cupboards in Ground floor reading room

35. 1 Foyer/Entrance Hall $=22 \mathrm{sq} \mathrm{m}$

1 toilet $=2.5 \mathrm{sq} \mathrm{m}$

1 toilet $=2 \mathrm{sq} \mathrm{m}$

1 photocopying room $=3.5 \mathrm{sq} \mathrm{m}$

1 lift, stairs to 5 levels

36. 6 levels, including the Computer room. All 6 levels are public levels

37. 95 in Library, 20 in Computer room, 14 in Seminar room 
39. 20 seats

40. 14 seats

41. 95 seats (with power points for laptops)

b) Total potential capacity of shelving (linear metres or volumes)

42. 30,500 volumes

43. 23,500 volumes

44. 7,000 volumes

46. 10 DVDs

48. 1.65

c) Mechanical features

49. Yes, in all rooms

50. Radiators heated by College central boilers

51. Low energy

52. Acoustic control to the river. Cooling available in summer, so windows can be kept shut

53. 1 lift to 5 levels: $\max$ no. of persons 8 , $\max$ load $630 \mathrm{~kg}$

54. Manual trolley

55. 3M security gates working in conjunction with tags in books. Networked camera.

\section{SCHEDULE OF THE BUILDING PROCESS}

59. June 1995-October 1996

61. 6 contractors tendered

62. June 1997

63. To September 1998 (15 months)

65. October 1998

\section{E COSTS}

66. Owned by College

67. $f 1,365,000$

68. Reading tables, spaces, lighting fittings in contract price. Additional $f 10,000$ (approximately) spent on chairs etc.

69. $f 150,000$

70. $f 1,525,000$ excluding VAT 


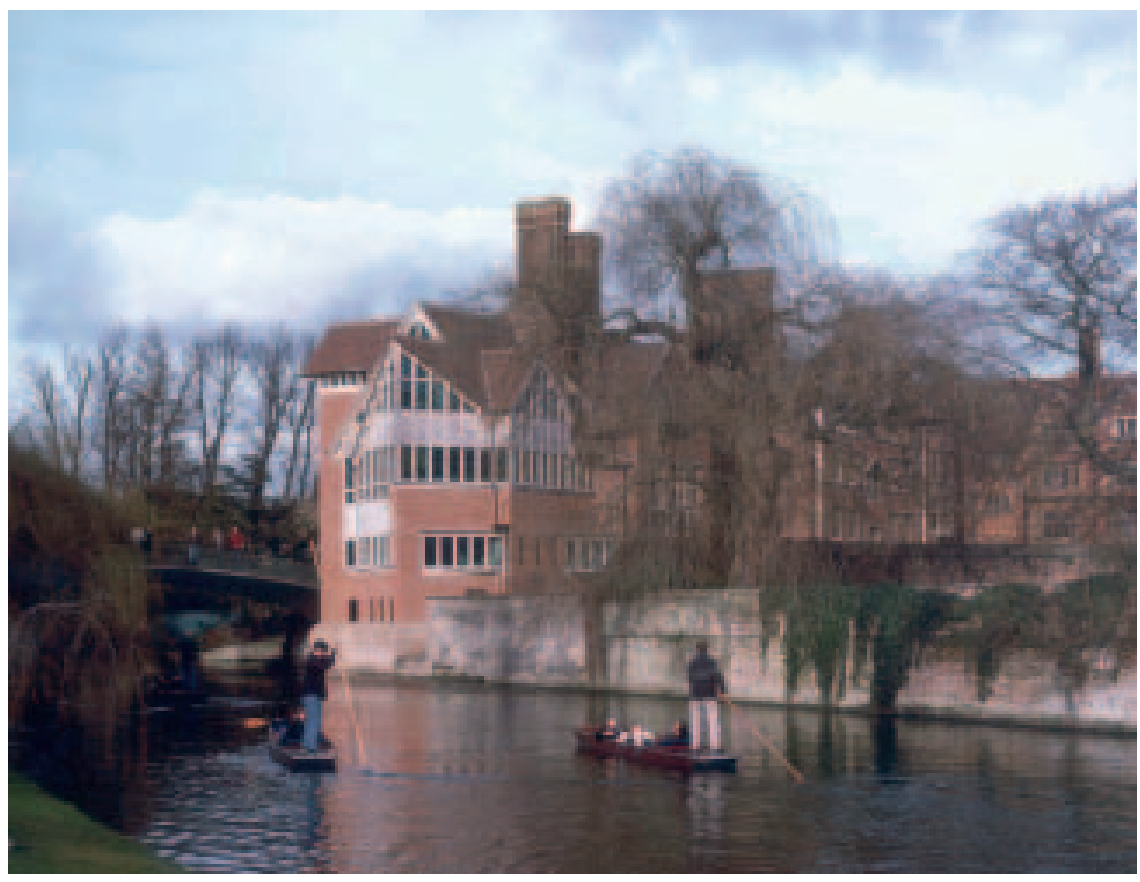

Trinity Hall, Jerwood Library 


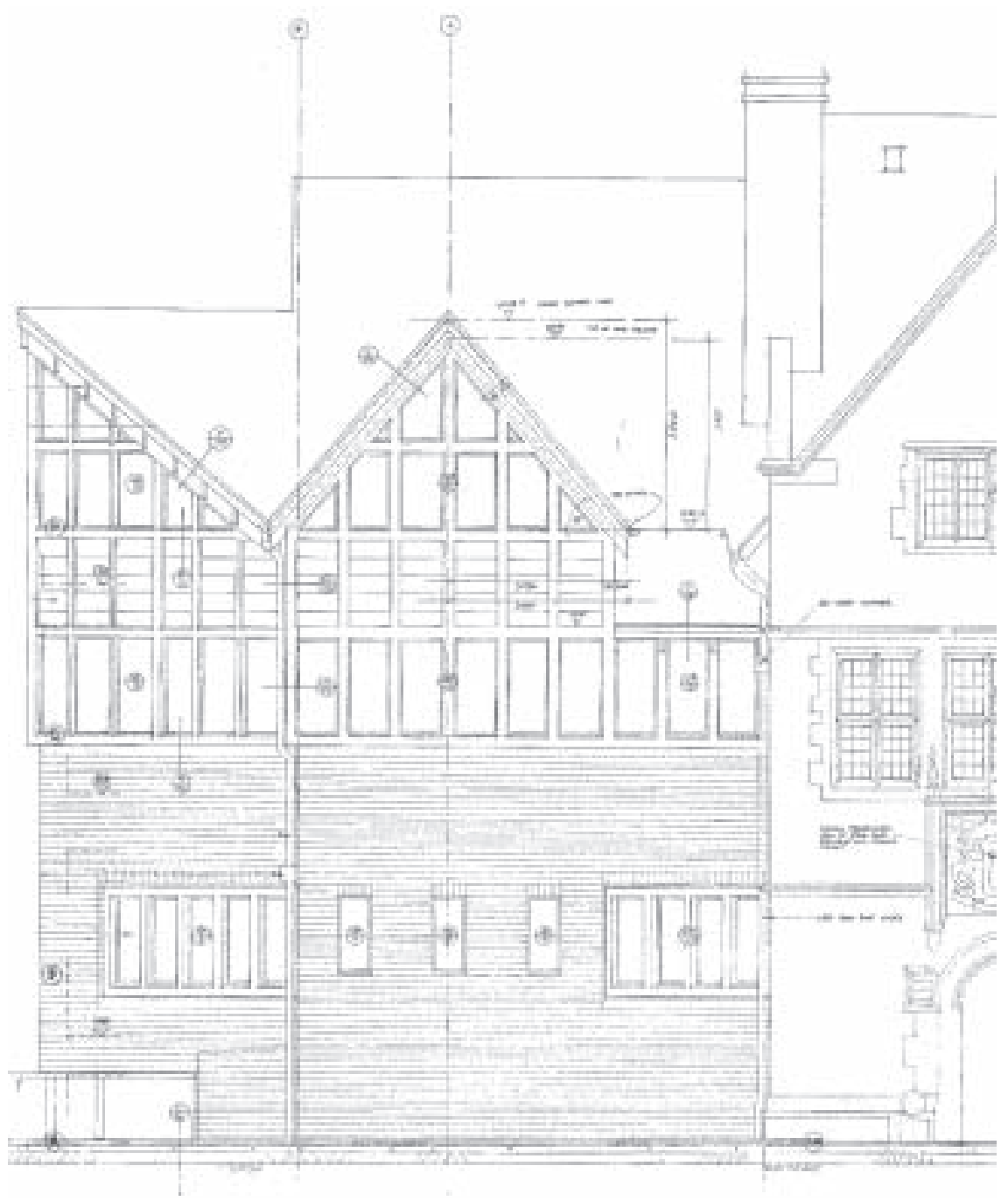

Trinity Hall, Jerwood Library, South elevation 


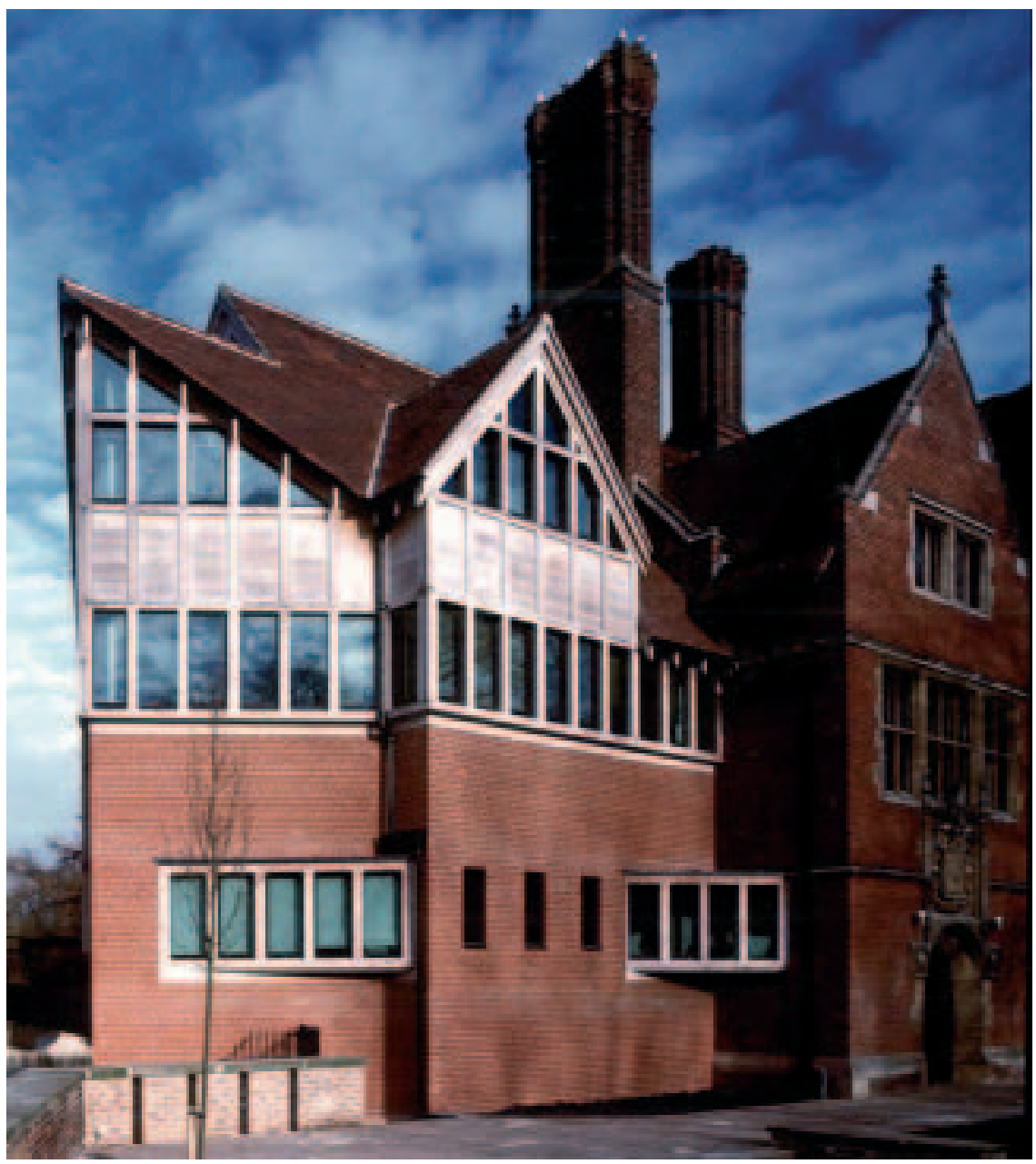

Trinity Hall, Jerwood Library 


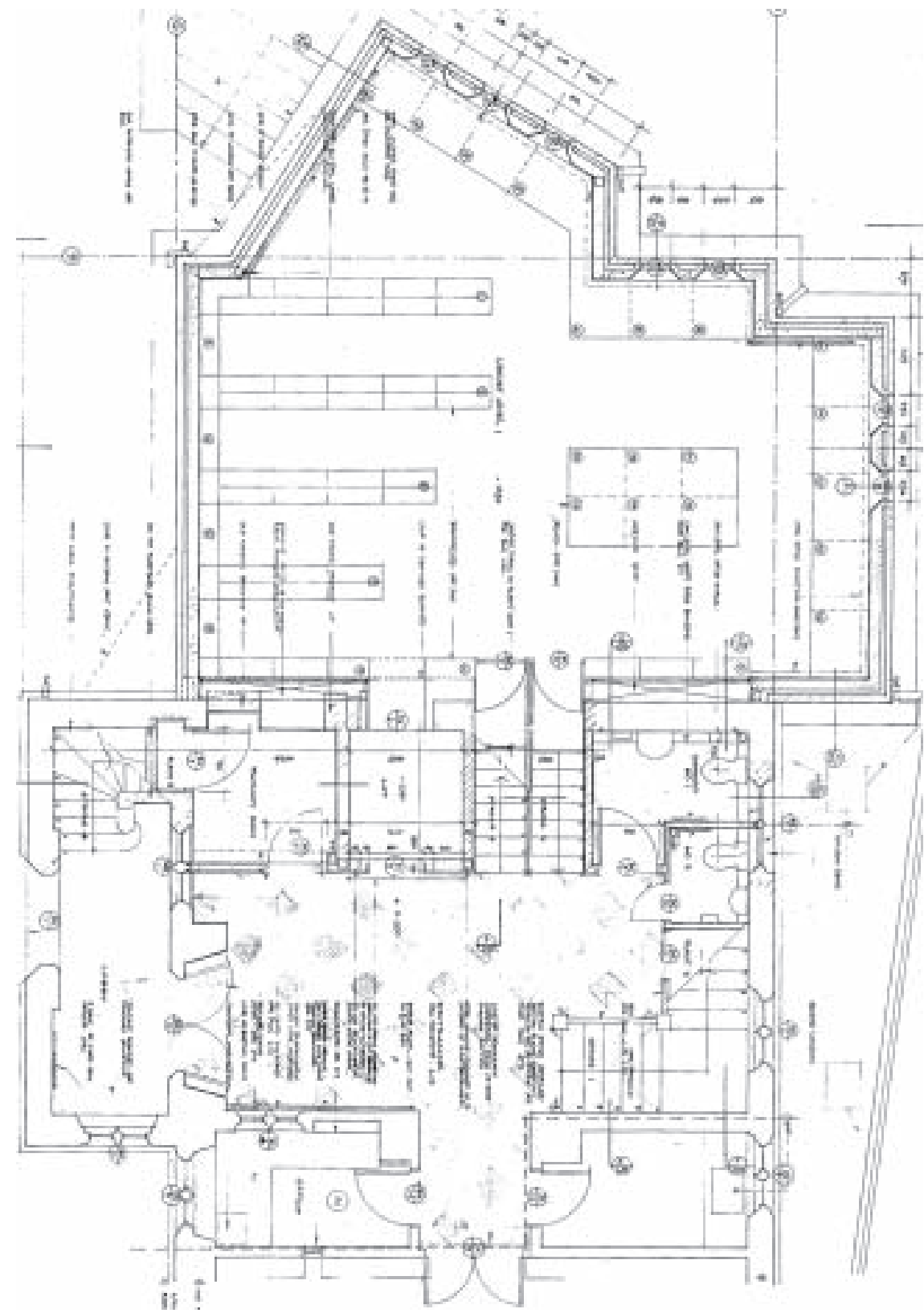

Trinity Hall, Jerwood Library, Ground floor plan 


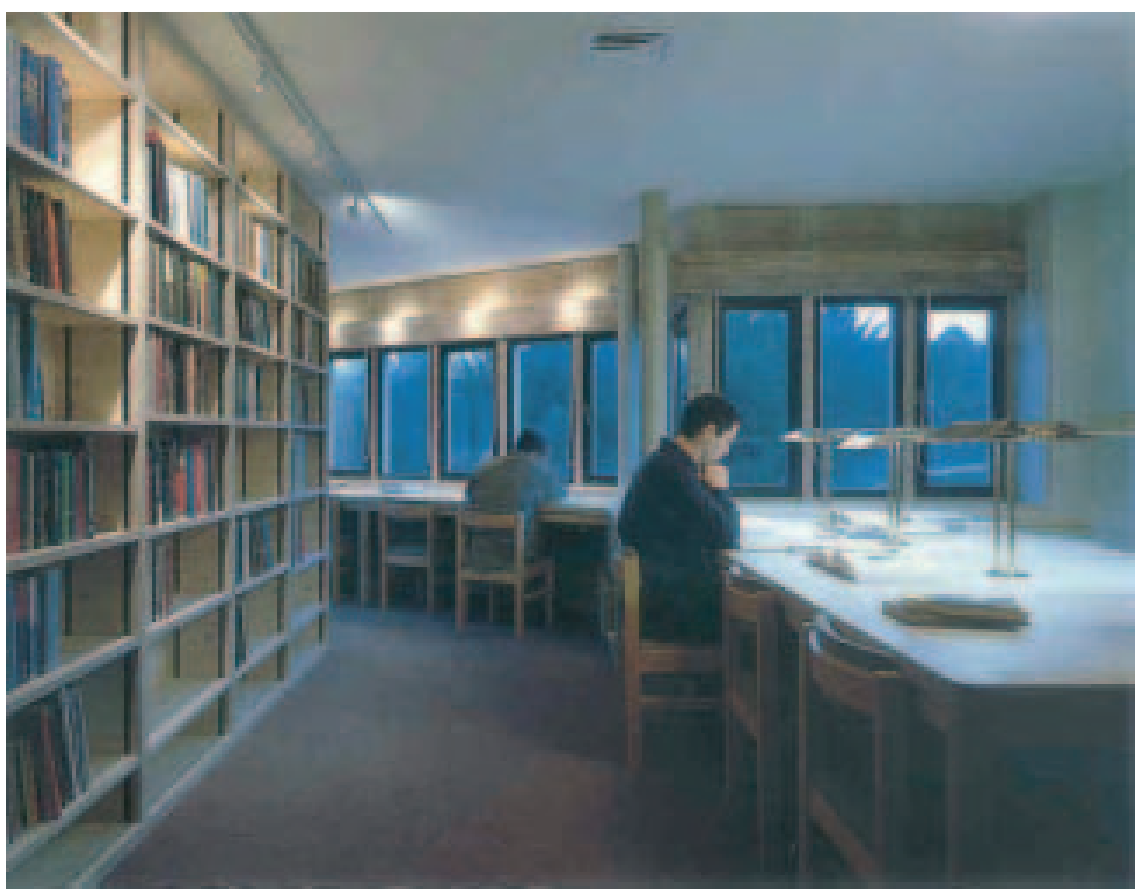

Trinity Hall, Jerwood Library 


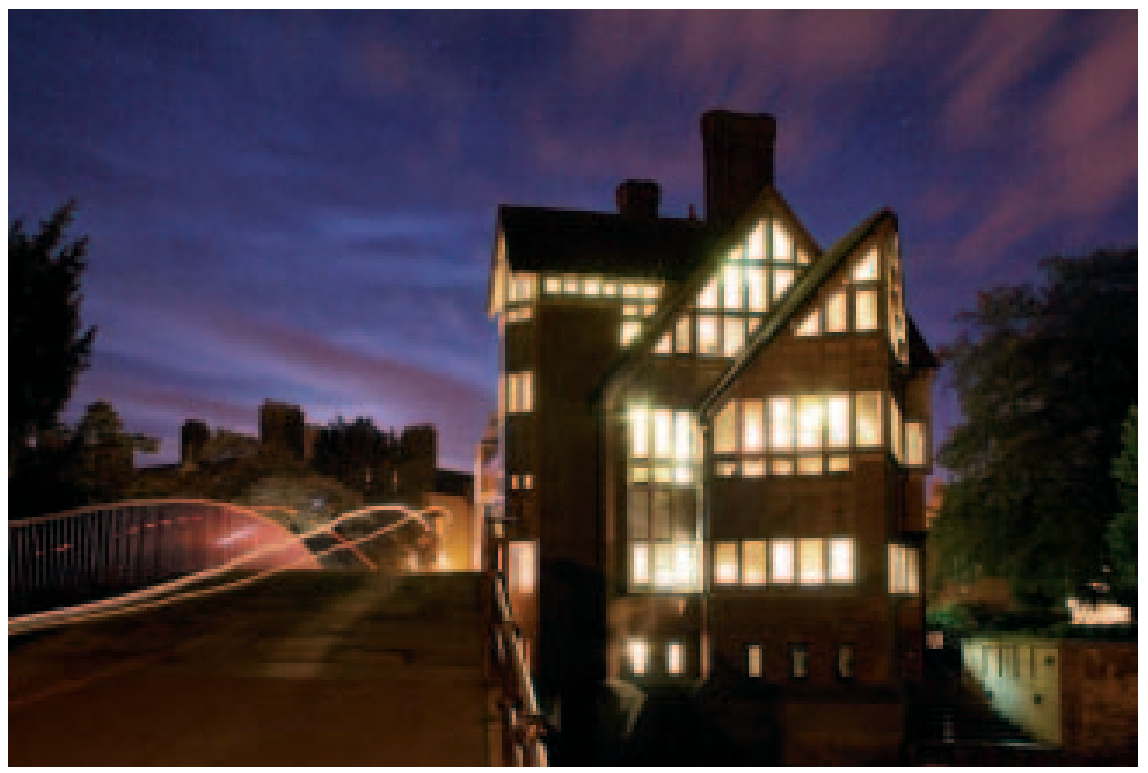

Trinity Hall, Jerwood Library

(c) 2005 Andrew Dunn@andrewdunnphoto.com, licensed to the public under http://creativecommons.org/licenses/by-sa/2.0/ 


\section{Wolfson College - Lee Library}




\section{A GENERAL INFORMATION ABOUT THE LIBRARY}

a) Name and address

1. Academic (UK Higher Education Sector). Caters mainly for undergraduate and taught graduate courses in the University of Cambridge. Open to members of Wolfson College only

2. Lee Library, Wolfson College

3. Wolfson College

Barton Road

Cambridge CB3 9BB

UK

4. Phone: +44 1223335965

Fax: $\quad+441223335908$

E-mail: library@wolfson.cam.ac.uk

5. Mrs Anna Jones (Lee Librarian)

6. Lee Librarian

b) Population served

7. 1276

8. 552

9. 157

10. 145

c) Conditions of the library (before the new project) 17. 24 hours a day

\section{B THE NEW BUILDING: AIMS AND FEATURES}

\section{a) Architect(s)}

18. Brewer, Smith and Brewer

19. Mr John Mills \& Mr David Williams

20. New building: yes

\section{b) Aims of the new building}

21. To provide study space for the College's growing population of students, at undergraduate and graduate level, and to provide storage in anticipation 
of the future expansion of the Library stock.

More holdings in open stacks

More readers seats

Computer and audiovisual materials

Extension of the opening hours to students

(The Library is now open 24 hours every day of the year, except for 1 week at Christmas)

\section{c) Special Features}

22. Located in College, near to student accommodation.

23. Rectangular plan with large central entrance area on Ground Floor. Large glass panels on stairway are a feature and make the building very light. Material = predominantly light-coloured stone and glass, with beige coloured metal window and door frames. Criteria for selection of materials not known. The floor of each level is flat and a lift provides disabled access to each floor. There are no steps at the entrance to the Ground Floor from outside.

\section{TECHNICAL INFORMATION ABOUT THE NEW BUILDING}

a) Floor area (in sq metres) for questions 24 to 33

24. $883.23 \mathrm{sq} \mathrm{m}$

25. $268.90 \mathrm{sq} \mathrm{m}$

27. $106.25 \mathrm{sq} \mathrm{m}$

29. $106.25 \mathrm{sq} \mathrm{m}$ (though not for regular Library use)

33. $17.9 \mathrm{sq} \mathrm{m}$

34. $90.97 \mathrm{sq} m$ (North Stack not used by Library)

35. $231.46 \mathrm{sq} \mathrm{m}$

36. 3 floors, all accessible to public

37. 49

39. 15

40. Max. 50 (not used for library purposes)

41. 34

b) Total potential capacity of shelving (linear metres or volumes)

42. $1426.16 \mathrm{sq} \mathrm{m}$

43. $651.16 \mathrm{sq} \mathrm{m}$ 
44. $775 \mathrm{sq} \mathrm{m}$

45. $775 \mathrm{sq} \mathrm{m}$ (Closed stack area is fitted exclusively with rolling stacks)

48. Current staffing $=1.27 \mathrm{FTE}$

\section{c) Mechanical features}

49. Air circulation system, without chiller

50. Low level radiators in Reading Room

51. Flourescent tubes hanging from ceiling, not used after 11.30 pm. Low energy wall lights for overnight use. Individual desk lamps

52. Carpet tiles minimise noise from people walking around

53. Max. 6 persons; access to all floors

55. Magnetic detection system. Strips in books set off alarm at exit if item is not correctly discharged

\section{SCHEDULE OF THE BUILDING PROCESS}

59. Donation pledged in 1991

62. Ceremonial foundation stone laid 28 September 1992

63. 18-24 months

65. Formal opening, September 1994

\section{E COSTS}

67. Not known. Funded by donation

70. Not known 


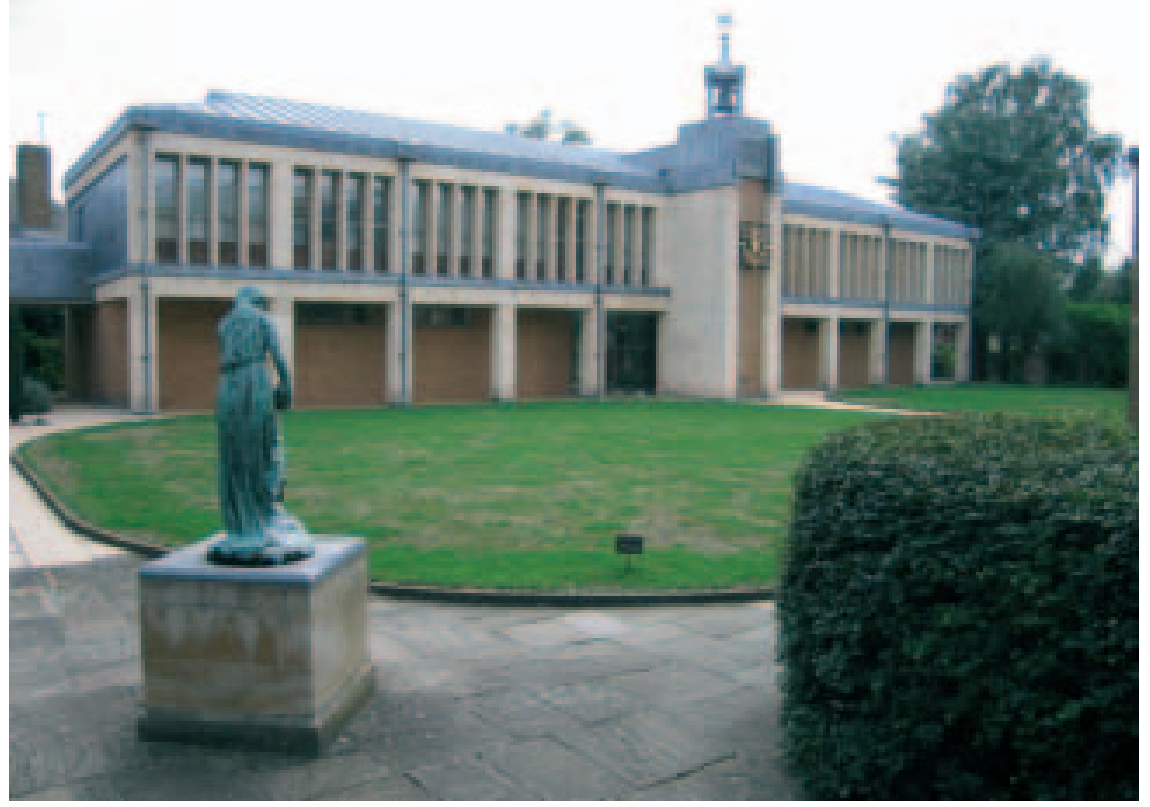

Wolfson College, Lee Library

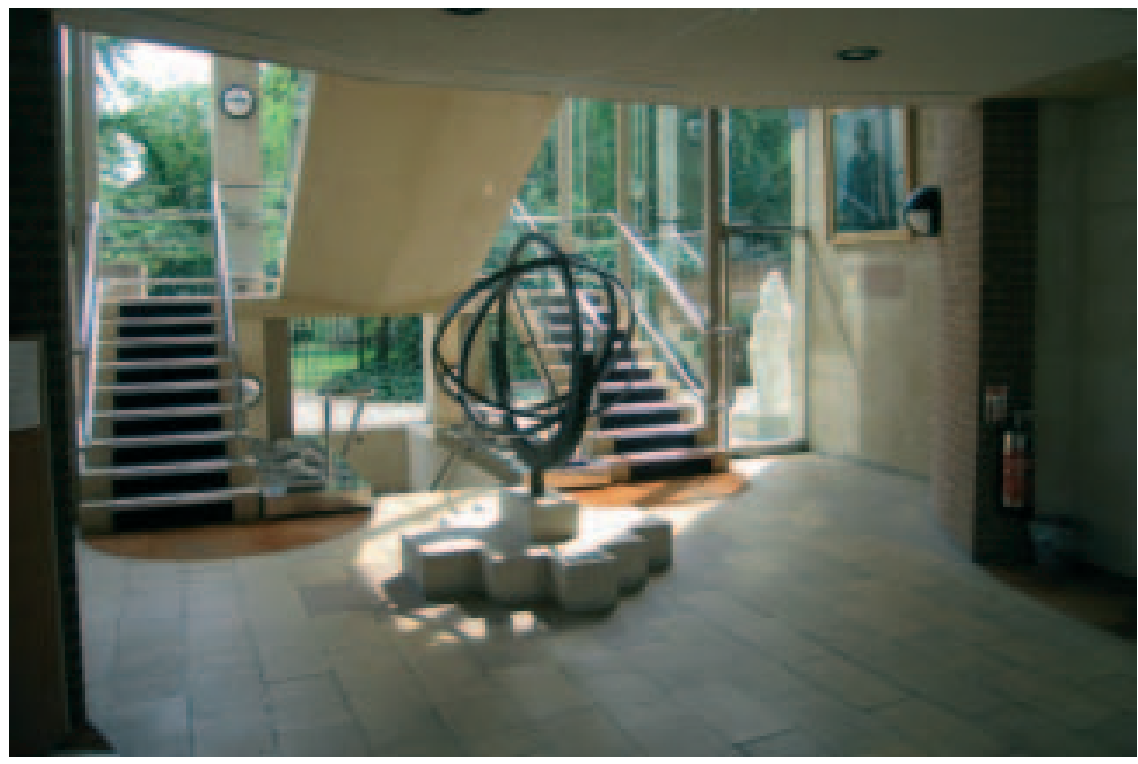




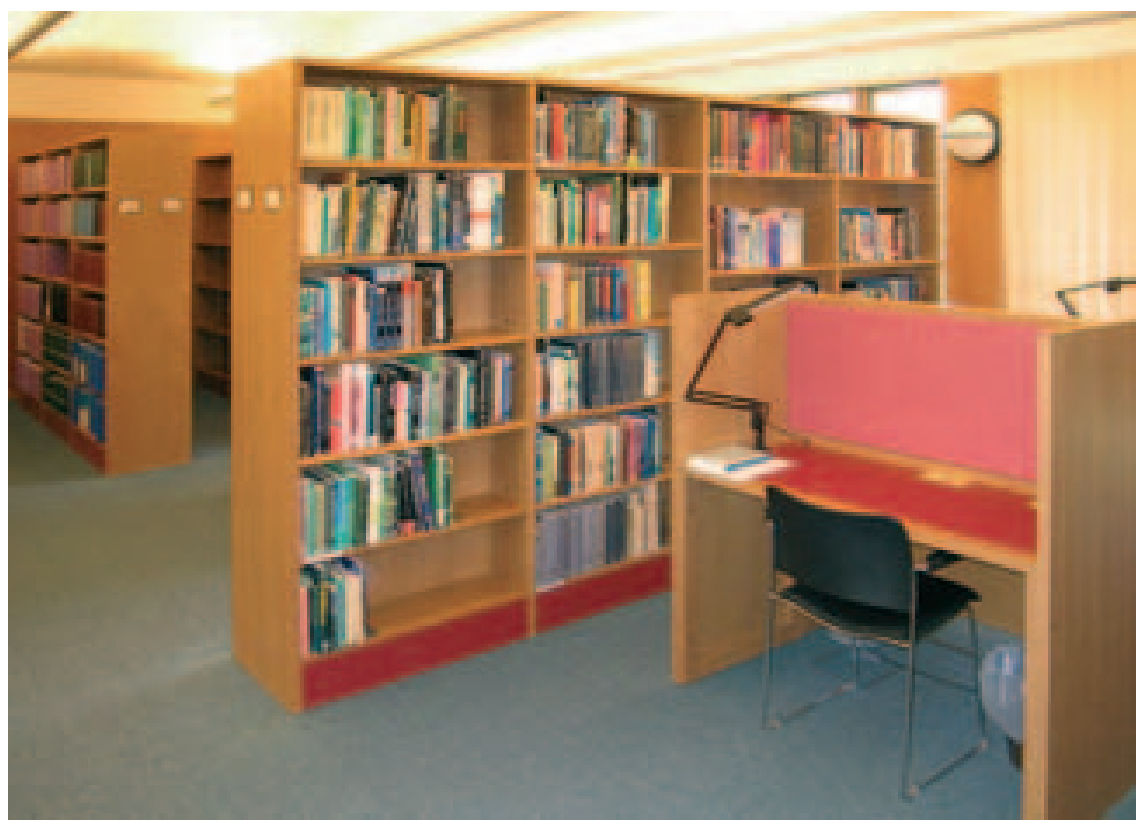

Wolfson College, Lee Library

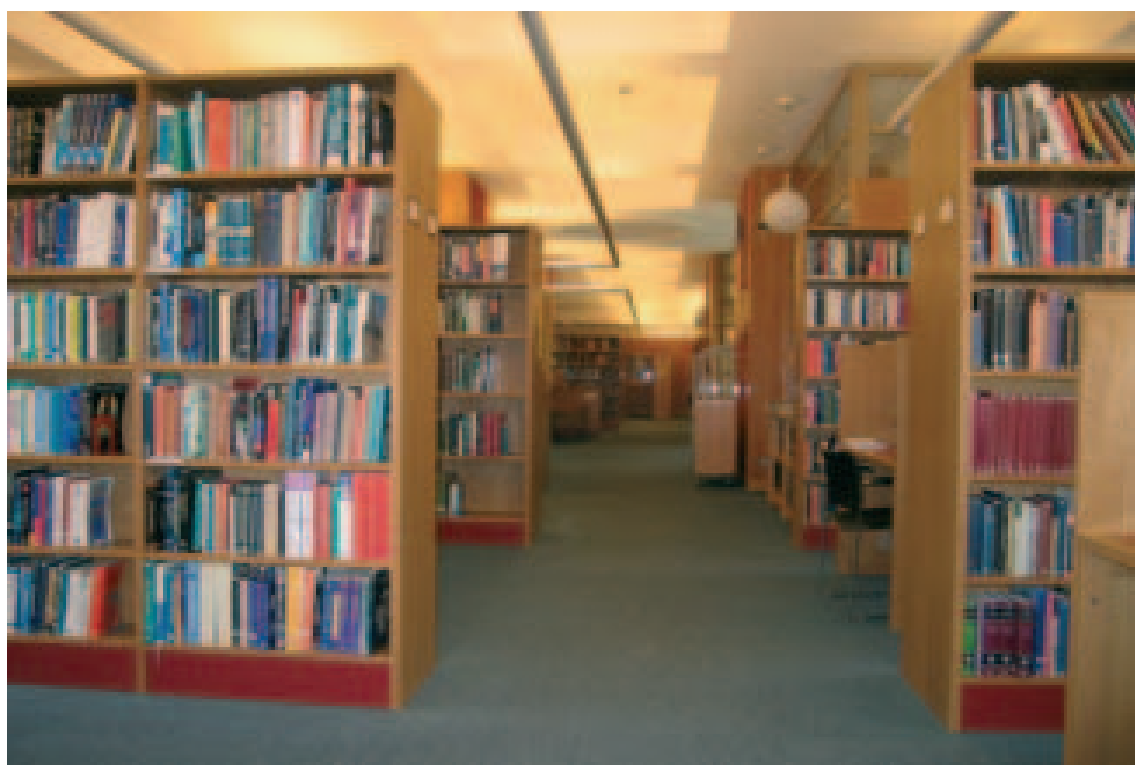





\section{Göttinger Bibliotheksschriften}

(items for sale)

1. Edith Stein. Studentin in Göttingen 1913-1916. Ausstellung zum 100. 4,- $€$ Geburtstag 7.10.-28.10.1991. 1991. 118 S.

2. Der Brocken und sein Alpengarten. Erinnerungen - Dokumentationen. 4,- $€$ Ausstellung vom 17.3.-5.6.1993. 1993. $81 \mathrm{~S}$.

3. Übersicht über die Systematik des Bandrealkataloges der Niedersächsischen Staats- und Universitätsbliothek Göttingen. Bearb.: G.-J. Bötte u. D. Sickmüller. 1993. XIII, 75, 126 S.

4. Neues Heimatland Brasilien. Texte und Bilder zur kulturellen Entwicklung der deutsch-brasilianischen Bevölkerung in Südbrasilien. Begleitband zur Ausstellung vom 10.1.-19.2.1994 / Sandra Messele-Wieser, Lothar Wieser. 1994. IV, 84 S.

5. Möglichkeiten der Beschaffung und Bereitstellung digitaler Karten im Sondersammelgebiet. DFG-Projektstudie. Bearb. von Christiane Beckert. 2002. $142 \mathrm{~S}$.

6. Kröger, Detlef: European and international Copyright protection. Micro- 10,- $€$ copies and databases. 1995. 283 S.

7. Bestandserhalt durch Konversion: Microverfilmung und alternative Tech- 10,- $€$ nologien. Beiträge zu drei Fachtagungen des EU-Projekts MICROLIB. 1995. $208 \mathrm{~S}$.

10. Sibirien Finnland Ungarn : Finnisch-ugrische Sprachen und Völker in der Tradition eines Göttinger Sondersammelgebiets. Ausstellung in der Paulinerkirche vom 28.2.-9.4.1998. 344 S.

13. "Göthe ist schon mehrere Tage hier, warum weiß Gott und Göthe": 14,- $€$ Vorträge zur Ausstellung "Der gute Kopf leuchtet überall hervor" Goethe, Göttingen und die Wissenschaft. 2000. VI, 295 S.

14. Towards consensus on the electronic use of publications in libraries: 7,- $€$ strategy issues and recommendations / Thomas Dreier. 2001. $120 \mathrm{~S}$.

16. Zehn Jahre Pica in Niedersachsen und Deutschland. Skizzen eines Erfolges. 5,- $€$ 2001. $181 \mathrm{~S}$.

17. "Wohne immer in meinem Herzen und in den Herzen meiner Freunde 10,- $€$ allesbelebende Liebe!" Friedrich Leopold Graf zu Stolberg (1750-1819). Aus der literarisch-historischen Sammlung des Grafen Franz zu StolbergStolberg, 1210 - 1750 - 2001 / Bearb. von Paul Kahl. 2001. 143 S. 
18. Johann Heinrich Voß. 1751-1826. Idylle, Polemik, Wohllaut. 2001. 298 S. 15,- $€$

19. Weltbild - Kartenbild. Geographie und Kartographie in der frühen Neuzeit 10,-€ / Bearb. von Mechthild Schüler. 2. Aufl. 2002. 94 S.

20. LIBER - Ligue des Bibliothèques Européennes de Recherche. Architecture 35,- $€$ Group Seminar. Leipzig, March 19-March 23, 2002. The Effective Library. Vision, Planning Process and Evaluation in the Digital Age. Documentation of new library buildings in Europe. 2002. 319 p.

21. Das Göttinger Nobelpreiswunder - 100 Jahre Nobelpreis. 2. Aufl. 2002. 22,-€ 377 S.

22. 300 Jahre St. Petersburg - Russland und die "Göttingische Seele". 2. Aufl. 14,- $€$ 2004. 502 S.

23. Das Göttinger Nobelpreiswunder - 100 Jahre Nobelpreis. Vortragsband. 11,-€ 2004. $194 \mathrm{~S}$.

24. Daniela Grebler, Kornelia Priesel-Agidigbi, Dirk Steinert: In Sachen AACR2. $5,-€$ Eine Bibliographie zur Second edition der Anglo-American cataloguing rules mit originalsprachigen und übersetzten Ausgaben sowie englischund deutschsprachiger Sekundärliteratur 1978-2002. 2004. V, 160 S.

25. LIBER - Ligue des Bibliothèques Européennes de Recherche. Architecture Group Seminar. Bozen/Bolzano, March 17-March 19, 2004. The Renaissance of the Library - adaptable library buildings. Documentation of new library buildings in Europe. 2004. 367 p.

26. Edward S. Curtis: The North American Indian. Die Indianer Nordamerikas. Ausstellung in der Niedersächsischen Staats- und Universitätsbibliothek Göttingen, 29.2.-18.4.2004 / Mit einer Einf. von Hans Christian Adam. 2004. 72 S.

27. Dieter Cherubim, Ariane Walsdorf: Sprachkritik als Aufklärung - Die Deutsche Gesellschaft in Göttingen im 18. Jahrhundert. 2. Aufl. 2005. 237 S.

28. Anne Ørbæk Jensen, Claus Røllum-Larsen, Inger Sørensen: Wahlverwandtschaften - Zwei Jahrhunderte musikalischer Wechselwirkungen zwischen Dänemark und Deutschland. 2004. 115 S.

29. Nützliches Vergnügen. Kinder- und Jugendbücher der Aufklärungszeit aus dem Bestand der Niedersächsischen Staats- und Universitätsbibliothek Göttingen und der Vordemann-Sammlung. 2004. 259 S.

30. "Wie der Blitz einschlägt, hat sich das Räthsel gelöst" - Carl Friedrich Gauß 12,-€ in Göttingen. 2005. 252 S. 
31. "Eine Welt allein ist nicht genug" - Großbritannien, Hannover und 16,- $€$ Göttingen 1714-1837. 2005. 450 S.

32. Kerstin Thieler: „[...] des Tragens eines deutschen akademischen Grades $8,-€$ unwürdig." Die Entziehung von Doktortiteln an der Georg-AugustUniversität Göttingen im „Dritten Reich“. 2. Aufl. 2006. 104 S.

33. Die spanische Aufklärung in Deutschland. Eine Ausstellung aus den $10,-€$ Beständen der Niedersächsischen Staats- und Universitätsbibliothek Göttingen. 2005. 114 S.

34. LIBER - Ligue des Bibliothèques Européennes de Recherche. Architecture Group Seminar. Utrecht, The Netherlands, March 22 - March 24, 2006 with a pre-seminar tour in Belgium and the south of The Netherlands, March 20/21, 2006. Changing Needs, Changing Libraries. Documentation of new library buildings in Europe. 2006. 327 p.

35. Göttinger Kostbarkeiten - Handschriften, Drucke und Einbände aus zehn 29,80€ Jahrhunderten. 2006. 286 S.

\section{CD-ROMs from the Goettingen State and University Library} (items for sale)

Die ganze Welt ist aus Papier. Graphiken und Objekte zu allen Gelegenheiten $\quad 18,-€$ 1800-1930.

"Der gute Kopf leuchtet überall hervor" - Goethe, Göttingen und die Wissenschaft.

Gutenberg digital. Göttinger Gutenberg-Bibel, Musterbuch und Helmaspergersches Notariatsinstrument.

Weltbild - Kartenbild. Geographie und Kartographie in der frühen Neuzeit.

Das Göttinger Nobelpreiswunder - 100 Jahre Nobelpreis.

300 Jahre St. Petersburg - Russland und die "Göttingische Seele".

The North American Indian - Fotografien von Edward S. Curtis.

Nützliches Vergnügen. Kinder- und Jugendbücher der Aufklärungszeit aus dem Bestand der Niedersächsischen Staats- und Universitätsbibliothek Göttingen und der Vordemann-Sammlung.

„Wie der Blitz einschlägt, hat sich das Räthsel gelöst" - Carl Friedrich Gauß in Göttingen.

Göttinger Kostbarkeiten - Handschriften, Drucke und Einbände aus zehn Jahrhunderten.

$15,-€$

$54,-€$

$20,-€$

$18,-€$

$14,-€$

6,- $€$

$12,-€$

$12,-€$

$9,80 €$ 